\title{
Indigenous Knowledge Production
}

Despite many scholars noting the interdisciplinary approach of Aboriginal knowledge production as a methodology within a broad range of subjects including quantum mathematics, biodiversity, sociology and the humanities the academic study of Indigenous knowledge and people is struggling to become interdisciplinary in its approach and move beyond its current label of 'Indigenous Studies'.

Indigenous Knowledge Production specifically demonstrates the use of autobiographical ethnicity as a methodological approach, where the writer draws on lived experience and ethnic background towards creative and academic writing. Indeed, in this insightful volume, Marcus Woolombi Waters investigates the historical connection and continuity that have led to the present state of hostility witnessed in race relations around the world, seeking to further understanding of the motives and methods that have led to a rise in white supremacy associated with ultra-conservatism.

Above all, Indigenous Knowledge Production aims to deconstruct the cultural lens applied within the West which denies the true reflection of Aboriginal and Black consciousness, and leads to the open hostility witnessed across the world. This monograph will appeal to undergraduate and postgraduate students, as well as postdoctoral researchers, interested in fields such as Sociology of Knowledge, Anthropology, Cultural Studies, Ethnography and Methodology.

Dr Marcus Woolombi Waters is a Lecturer in the School of Humanities, Languages and Social Science at Griffith University, Australia. 


\section{Routledge Advances in Sociology}

For a full list of titles in this series, please visit www.routledge.com/series/ SE0511

Reflections on Knowledge, Learning and Social Movements

History's Schools

Edited by Aziz Choudry and Salim Vally

Social Generativity

A relational paradigm for social change

Edited by Mauro Magatti

The Live Art of Sociology

Cath Lambert

Video Games as Culture

Considering the Role and Importance of Video Games in

Contemporary Society

Daniel Muriel and Garry Crawford

The Sociology of Central Asian Youth

Choice, Constraint, Risk

Mohd. Aslam Bhat

Indigenous Knowledge Production

Navigating Humanity within a Western World

Dr Marcus Woolombi Waters

Time and Temporality in Transitional and Post-Conflict Societies

Edited by Natascha Mueller-Hirth and Sandra Rios Oyola

Practicing Art/Science

Experiments in an Emerging Field

Edited by Philippe Sormani, Guelfo Carbone and Priska Gisler

The Dark Side of Podemos?

Carl Schmitt and Contemporary Progressive Populism

Josh Booth and Patrick Baert 


\section{Indigenous Knowledge Production}

Navigating Humanity within a Western World

\section{Dr Marcus Woolombi Waters}


First published 2018

by Routledge

2 Park Square, Milton Park, Abingdon, Oxon OX14 4RN

and by Routledge

711 Third Avenue, New York, NY 10017

Routledge is an imprint of the Taylor \& Francis Group, an informa business

(C) 2018 Marcus Woolombi Waters

The right of Marcus Woolombi Waters to be identified as author of this work has been asserted by him in accordance with sections 77 and 78 of the Copyright, Designs and Patents Act 1988.

The Open Access version of this book, available at www.taylorfrancis.com, has been made available under a Creative Commons Attribution-Non Commercial-No Derivatives 4.0 license.

Trademark notice: Product or corporate names may be trademarks or registered trademarks, and are used only for identification and explanation without intent to infringe.

British Library Cataloguing in Publication Data

A catalogue record for this book is available from the British Library

Library of Congress Cataloging in Publication Data

A catalogue record for this book has been requested.

ISBN: 9781138218383 (hbk)

ISBN: 9781315437811 (ebk)

Typeset in Times New Roman

by Taylor \& Francis Books 


\section{Contents}

Biiba-ga guwaa-lda-ndaay ( A note from the author ...) vi

Biiyaal (Preface ...) viii

1 Yammaa gamilaroi winnunguldah

(Introducing autobiographical ethnicity ...) 1

2 Gamil bida-wii (Before the beginning ...) 16

3 Ngamilma-li-ayla-y (Background to the study ...) 30

4 Guwiinbaa-gi ngamuulah biibabiiba (Moving towards $\begin{array}{ll} & \\ \text { the book ...) } & 48\end{array}$

5 Nguwa ... ngay dhubaanma-li gay (Here ... I'll tell you $\begin{array}{ll}\text { a story ...) } & 68\end{array}$

6 Nhuubala winanga-y-baa (A new hypothetical space ...) 84

7 Burranba-li ngay guyungan-dhu ali-y (The fluidity of my

8 Wiringin-dhiiral (An Indigenous academy ...) 116

9 Minya burrul burranba-li mubirr (What inspired the writing ...) 134

Waaran (Conclusion ...) 149

Waaran garaay (Final word ...) 153

$\begin{array}{lr}\text { References } & 166\end{array}$

$\begin{array}{ll}\text { Index } & 185\end{array}$ 


\section{Biiba-ga guwaa-lda-ndaay (A note from the author ...)}

What does it mean to be Aboriginal in the 21st century? To be connected to the land beyond materialism and commodity, where instead your connection is within the kinship ties, and the very DNA you possess that comes from the land you walk on. Surely in connecting to the land our very humanity is then connected to our Aboriginality. As the oldest living culture practised today our Aboriginality is our divine authority and birthright to exercise autonomy, ownership and leadership as the original peoples of these lands in which we remain connected to today. To claim ownership in our wellbeing free of trauma as a people belonging to the lands of their ancestors over tens of thousands of years we share a noble birth in carrying the legacy of our languages, our ceremony and our way of life into the future. As a Kamilaroi Australian Aboriginal I live in one of the richest Western countries in the world, built on an industry of mining from the lands of my own Aboriginal people, many of whom remain living in third-world poverty and associated trauma.

This is poverty and trauma I have seen and felt personally. Just over 12 months ago I took a one-year sabbatical to write this book. I left Australia for New Zealand to be picked up by my white sister, who is also my aunt, having been adopted by my white grandparents after being taken from my Aboriginal mother 48 years ago. My narrative is unique in that rather than writing about my being taken or returning to my Aboriginal family, a text many are familiar with due to publications already documenting Australia's Stolen Generations ${ }^{1}$ including Follow the Rabbit-proof Fence (Pilkington, 2013) and My Place (Morgan \& Reynolds, 1987), I am now returning to the white family that reared me. Hopefully in coming full circle within my own healing process. My first emotional trigger is in giving into the white privilege I walked away from as a teenager in being reunited with my Aboriginal family over 30 years earlier.

My sister lives in a million-dollar house in Wellington, the nation's capital. To my Aboriginal family, owning a million-dollar house is as far removed from reality as travelling to the moon. As Aboriginal people we just don't own million-dollar houses, but for many white Westerners living in major cities around the world, including Wellington, Auckland, Sydney or Melbourne, this is neither extraordinary nor extreme ... in fact, it is normal. You just can't get standard four-bedroom housing in these inner cities for anything 
less than A \$700,000. It's why you don't see Blackfellas ${ }^{2}$ living in inner Sydney or Melbourne, as a form of socioeconomic cultural apartheid (Wright, 2002). I stay with my sister for two days as, together with my two boys, Ngiyaani (13 years old) and Marcus junior (12 years old), we get reacquainted. I purchase a car from a car-yard owned by a friend of her husband, well under market value; because of the relationship with family the car has been checked out and is running A1 mechanically. I pay cash, which is expected, and leave for Hastings, which is a four-hour drive away, with peace of mind and security knowing the car won't break down or be in need of constant maintenance, even though I paid less than A \$2,000. It is hard describing such purchases as white privilege, or even as a benefit to those who see such social and cultural capital as 'matter-of-fact' or as personal agency they believe acquired from hard work, but I have lived with poverty associated with my Aboriginality and these are not securities associated to everyone - where even a safe, reliable car appears out of reach. I arrive in Hastings and take up residence in a house owned again by a friend of the family, and together with my two boys and my white family we start a process of what I hope will be healing.

It's now 12 months later and I am calling my wife in Australia to arrange coming home; the book is almost finished and I feel accepted and loved by my white family. In discussing coming home my wife explains that her brother, an institutionalised criminal and drug addict, is coming to live with us because he has nowhere else to stay. This is after her cousin, a single mother who has three children in her care and another child not in her care, had to leave the house because of domestic violence and issues associated with the drug known as 'ice'. Welcome to the reality of being Aboriginal and living in Australia in the 21st century. I understand that such circumstances are not the same for every Aboriginal family, just as million-dollar houses in capital cities and being friendly with business owners who own car-yards and multiple rental properties are not every white person's experience. But neither my white nor my Aboriginal family are exceptional or extraordinary; in reality both are very average and these experiences are common boundary indicators for white and Aboriginal families alike. Obviously, as with anything, there are exceptions, but as stated above, both families are relatively normal and these are my own personal lived experiences which have shaped and nurtured the rest of the book.

Finally I have to make special note that my $\mathrm{PhD}$ thesis, titled Contemporary Urban Indigenous 'Dreamings': Interaction, Engagement and Creative Practice, was a major influence and particularly instructive in now writing this book, and will be referenced throughout the text.

Ngay gabayiindagh gaay-li biibabiiba (I thank you for reading ...).

Dr Marcus Woolombi Waters 


\section{Biiyaal (Preface ...)}

Yammaa Woolombi Gawuban Gunigal Gamilaraay Kamilaroi Waters. I introduce myself traditionally, as a representative of the Australian Kamilaroi First Nation Aboriginal People. With each word stated I clear a pathway of intellectual property and established First Nation boundaries connected to land in which I am acknowledged as a ceremonial keeper and language speaker. This is authority spoken in language that provides access to not only separate Aboriginal nations, but also the statesmen and -women of these lands. This is a system of acknowledgment that continues outside the paradigm of the Western institution, their government and the academy. Due to a process of neo-colonialism, our collective voice as Aboriginal people has become silenced via the hegemonic principles of Western education, control of the media and government sanctions promoting values diametrically opposed to sustaining Aboriginal culture and wellbeing (Burrows, 2016, p.91). In short, altruism and austerity from the West defined as neoliberalism is destroying our very way of life.

Neoliberalism is based on a belief the market should be the organising principle for social, political and economic decisions, where policy makers promote privatisation of State activities and an increased role for the free market, flexibility in labour markets and trade liberalisation. The benefits of these policies frequently fail to reach the Indigenous peoples of the world, who acutely feel their costs, such as environmental degradation and loss of traditional lands and territories.

(United Nations, 2009, p.16)

As one of the oldest living cultures in the world (Clarkson et al., 2017), our recent history has been one of forced assimilation. As a people we are opposed to forms of differentiation based on ascribing negative characteristics to those whom non-Aboriginal people label as 'others'. My writing is therefore about inclusion and acceptance, not forced exclusion and denial. My strategy in applying autobiographical ethnicity ${ }^{3}$ - is to inscribe my own ethnic, cultural and racial background by scholarly and creative means, utilising contemporary academic and creative voices: research and storytelling as 
expressions of life experience in an active partnership between myself as the author and you as the reader. The written text created as an experiment in thought and a research tool that utilises key philosophies embedded in our Kamilaroi Aboriginal First Nation epistemology before the arrival of the 'Whiteman' - and as a reinvestigation of them. By this means, I move Indigenous scholarship away from academic critique and further towards a provisional Aboriginal third space beyond the hypothetical third space as proposed by Bhabha (1994), which can document a parallel validity and authenticity for both the coloniser and the colonised - black and white, Aboriginal and non-Aboriginal.

My written narrative is related to practice-led research, which, in the humanities, does not adopt a generic research strategy, as black and white, pardon the pun, which would raise epistemological issues (Bell, 2006, p.85) for those in the West driven by the need to understand. I acknowledge that in such creative practice-led research, through the very 'written text' and its 'resource', coming from the lived experience and ethnicity of the writer its practitioners tread a fine line 'between the generative act that brings a work into existence and the receptive act that is a proper appreciation of that work' (Davies, 2004, p.26). Even so, the advantages as stated by Wissler (1997) far outweigh the disadvantages in wanting to be heard; in more simple terms, living the experience provides far greater understanding than reading or observing that experience as documented by others:

between demonstrating our capacity to engage the discourses of other disciplines (in order to make our case more easily understood), and actually distorting the most powerful characteristics of our field ...

(Wissler, 1997, p.88)

While negotiating these boundaries, autobiographical ethnicity also creates a space for a reservoir of knowledge which I believe is presently 'untapped' in Western knowledge production. In striving for equity, not equality, my aim is to continually recognise and challenge the binaries that privilege some agendas and marginalise others. By sharing assumptions, beliefs and practices, the text invites the possibility that something new can emerge from such an encounter in generating innovative understandings that will inform future practice currently missing in a world separated from within its own humanity. Through my own life experience and academic scholarship I have come to understand that it is not only those marginalised by the current systems who appreciate such narrative, 'but those who are privileged also benefit as they become more aware of an ever changing world around them' (Sammel \& Waters, 2014). This is no better demonstrated than in an Instagram post by the white US actor Matt McGorry from the television show Orange is the New Black towards the end of 2015 in discovering his own white privilege. 
'The New Jim Crow' by \#MichelleAlexander is absolutely brilliant. ... the US criminal justice system fails and discriminates against people of color and specifically black folks. I'm embarrassed that I didn't come across the information in this book sooner. But that's white privilege for ya. I was never directly affected. If you have any interest in understanding the complexities of systemic racism in America, this is a must read. Burning crosses and racial slurs are not the only types of racism affecting people of color. And we owe it to our black and brown brothers and sisters to understand this. We can't pretend we live in a world where everything is even CLOSE to equal.

(McGorry, 2015)

Let us be clear: yes, I am coming from the position of an Australian Aboriginal, but I have a story that is relevant, both in my Aboriginality, but also my blackness and my oppression, the world over. It is impossible to enter into discussion about binaries without referencing my traditional homelands particularly concerning Aboriginal people and Australian history, white and black and everything else that falls in between. One connection we share as black and Aboriginal people, and it would be wrong to not bring this upfront in any discussion about colour and race throughout the West, is the associated trauma we carry from generation to generation. Both as the perpetrator and the victim the trauma is intergenerational, it is historical and it resides deeply in the present: "The settler colony is an enduring "structure, not an event" (Haebich, 2016, p.1). Haebich goes on to say it is imperative that we 'be aware of the repeated, ongoing constraints of settler colonial formations in the present time of neoliberalism in the Australian context' (Haebich, 2016, p.1). Like many of my brothas and sistas, mothers and fathers and children in carrying the ongoing ceremony language and the culture of my people, I also carry their pain. I understand that in ceremony I am reliving trans-generational history through teaching, and this recounting of history connects me to the memories and trauma of my marraan (ancestors), many of whom lost their lives in horrific circumstances. What I gain in return when such trauma arises in me goes far beyond just connection to the stories of my marraan, my sacred lands and kinship systems I belong to ... I am able to travel back and forth through time in a reciprocal process of active engagement within both our present location and the accumulated stories of the past. It is here that autobiographical ethnicity foregrounds my Aboriginal experience above the observational data taken as field notes or audio-visual documentation seen in ethnographic writing (Semali \& Kincheloe, 2002) and beyond Western research methods in documenting Indigeneity.

Autobiographical ethnicity becomes a tool to negotiate the meta-narrative landscape and assert our Aboriginal voices as original. In exploring the liminal space it opens up to us we are able to journey inwards into the crucible of our ancestry, a space in non-linear time that accesses these experiences as ritual and ceremony carried within tens of thousands of years of accumulated 
ancestral wisdom. It is to these rituals of the ordinary, the most humble and forsaken that I can turn in seeking solace unified in the solidarity of not only my Aboriginality, but also my humanity. This is a comfort and sense of place built over tens of thousands of years that remains priceless - and unfortunately those who live in the immediacy of the modern world and crave material fulfilment lack understanding of this timeless Aboriginal moral principle. This is best demonstrated by Dalinkua and Dalipie, two Meeanjin (Brisbane, Australia) blacks who were residents of an Aboriginal settlement called Zion Hill run by Lutheran missionaries over 150 years ago, referenced by historian Raymond Evans:

that 'in instinct and moral principle' the Aborigines were 'immeasurably our superiors'. 'You live like a bird of prey', two missionary trained Breakfast Creek blacks, Dalinkua and Dalipie, had admonished whites in the late 1850's, 'and if you amass wealth, you soon become a bird of passage ... you do not seek the good of the land where you dwell'.

(Evans, 1992, p.87)

The reference comes from a series of letters published in the local newspaper, the Moreton Bay Courier, during the 1850s, written by Dalinkua and Dalipie. The letters cited the relationship between Aboriginal and non-Aboriginal better than I ever could. Dalipie in particular showed much promise in the literary arts, and was able to speak and write in many languages including English, Greek and Latin (Evans, 1988). This was not as amazing as it seems, since many local Aboriginal people were multilingual, having to speak a number of Aboriginal languages when growing up in the area prior to colonisation (Steele, 1983, pp.160-162).

My connection to the past is the very premise of my research journey, as like tens of thousands of Aboriginal people in Australia my birth mother did not rear me. There was and continues today a practice of removing Aboriginal children from their families in Australia under a policy of 'child protection' (Gibson, 2013; Haebich, 2016). This was a separation that has had a massive influence over my life, my mother's life and her grandchildren - the truth is you can't begin to imagine the damage done, nor can I put into words the collective trauma that sweeps over Aboriginal people who in their tender moments of infancy were assigned to white paternal parents or foster homes to endure abuse, alienation, torment and a life as an indentured labourer (Kidd, 2006). To be told that you were 'worthless' - less than worthless 'beaten and sexually abused' (Attorney-General's Department, 2014). What has happened and is continuing to happen in Australia is one of the greatest unstated crimes against humanity seen in any modern civilisation. An extension of these 'Stolen Generations' is the Australian government's continued efforts to displace people from their traditional homelands in denial of our custodial obligations and responsibilities. I write this book to scream out in 
anguish that these crimes continue today and are not lost in the unwritten pages of history.

Aboriginal people today are forcefully being denied access to the land and all its creation - the rocks, the trees, the rivers and animals, as central to our belief systems forged over tens of thousands of years. This displacement has created a loss of 'feeling' and 'belonging' to country, identity and place that is leading our people into despair, such is the importance of family and connection to land within our traditional kinship systems (Kingsley et al., 2013). As a result, Aboriginal Australians represent the highest suicide rates in the world (Georgatos, 2013), with children as young as eight taking their own lives (Robinson \& Burrell, 2014). Our incarceration rates today are five times higher than blacks during the peak of Apartheid in South Africa (Graham, 2009; Loewenstein, 2013). These are figures that demonstrate not only the deep psychological damage resulting from being denied our connectivity to family, country and culture, but Australia's entrenched institutionalised racism (Albrecht et al., 2007) that maintains our oppression.

I am writing this passage only a day after 60,000 people marched in the streets in Australia and the world protesting the forced closure of remote Aboriginal communities from 96 locations around the globe (Cook, 2015) our very identity, faith system and wellbeing are connected to this land (Grieves, 2009). The ongoing forced removal of Aboriginal people from their homelands demonstrates the complete denial of Aboriginality in our own country since European invasion. It also highlights that while the rest of the world is debating whether we are in the age of either the post-colonial or neocolonial, Australia itself remains in a process of active colonialism that must be identified and acknowledged for what it is before my own Aboriginal people can ever begin to move forward. The effects of this active colonial practice are as devastating as they are horrifying.

Nhalay-nga ngay gaay (here is my story) ...

\section{Notes}

1 Between 1910-1970, many Australian Aboriginal children were forcibly removed from their families as a result of various government policies. The generations of children removed under these policies became known as the Stolen Generations. The policies of child removal left a legacy of trauma and loss that continues to affect Aboriginal communities, families and individuals today.

2 A term of endearment, Blackfella (also blackfellah, black fella, or black fellah) is used in Australian Aboriginal English to refer to Aboriginal Australians in acknowledgement of their being a 'black race'. It is generally considered to be a neutral term, but can also be used as derogatory, 'typical useless Blackfella', or as a form of empowerment, 'deadly strong Blackfella' or 'he is a real Blackfella real cultured fella strong in his law', and is used by black and white, Aboriginal and non-Aboriginal people throughout Australia.

3 As an Australian Aboriginal Kamilaroi-language speaker and writer I am interested in the lack of agreement in what constitutes Aboriginal epistemology and pedagogy 
Biiyaal (Preface ...) xiii

within the Western academy. I propose autobiographical ethnicity as the analytical position from which I write in connection to the conversations we as Aboriginal people have been having from generation to generation for tens of thousands of years - conversations that establish our worldview and position within the 21st century as separate and unique from the West. Autobiographical ethnicity acknowledges storytelling within our own Aboriginal families, our histories outside the Indigenous academy as demonstration of a parallel tradition of intellectual development and understanding beyond that which is connected to an act of colonisation. 



\section{Yammaa gamilaroi winnunguldah (Introducing autobiographical ethnicity ...)}

I was blessed in having returned to my Kamilaroi First Nation Aboriginal community as a teenager now over 30 years ago to find that we had retained our traditional ceremonies, our cultural practice, and ngiyani guwaa-li-gaay Gamilaraay (we still spoke in our own language). As I have got older I have become aware that not all Aboriginal Nations were so lucky, with many denied such practices due to the trauma, theft and brutality of colonisation.

We were a very lonely, lost and sad displaced group of people. We were taught to think and act like a white person, but didn't know how to think and act like an Aboriginal. We didn't know anything about our culture.

(Wilkie, 1997, p.152)

In wanting to engage directly within my own Aboriginality and at the same time remain inclusive to other cultures, while paying respect to 'academic rigour' and scholarship, I introduce autobiographical ethnicity as my narrative (Waters, 2012b). It is a form of writing that generates greater emphasis on the Aboriginal voice than either autobiographic or autoethnographic writing. This is because autobiographical ethnicity moves beyond the qualitative research method, predominantly framed by anthropologists, for which ethnographic writing was born. Rather than prioritising the needs of the academy, autobiographical ethnicity originates from traditional forms of Aboriginal ceremony and storytelling, which will become central throughout the book. It is a custom of Aboriginal narrative as old as Aboriginal people ourselves ...

This custom is still observed, and the first question of a stranger is, 'What murdoo?' - i.e., 'Of what family are you?'

('Gason's Dieyeri tribe', Cox, 1874, p.13, cited in Fison \& Howitt, 1991 [1880], p.25)

The above excerpt describes traditional Aboriginal acknowledgement as practised and still maintained today through 'Welcome to Country' ${ }^{1}$ and other rituals connected to Aboriginal peoples. In identifying authority and intellectual property associated with one's identity through country via 


\section{Yammaa gamilaroi winnunguldah}

Aboriginal Nation and family, a position is formulated in acknowledging a person's right to speak - put simply, deeper meaning is given to our own Aboriginal voice if we can place ourselves within the very community we represent, which is the very basis and rationale of what I propose as autobiographical ethnicity. Whether through traditional ceremony or as an academic scholar, it then remains essential to my own narrative that I am able to cite lived experience and family connection to community rather than 'as purely observational "data" taken as field notes or audio-visual documentation as seen in ethnographic writing' (Waters, 2016a, p.20).

In writing something that is both fresh and inclusive, remembering the essential ingredient of such practice is in welcoming the culture of an outsider - I want to make it clear that I refuse to surrender my non-Aboriginal identities, as in addition to my being Kamilaroi Australian Aboriginal, which remains my first reference point and worldview, I am both white of Irish heritage as well as black in acknowledgment of my people as a black race. In wanting to negotiate the current binaries of black and white, Indigenous and non-Indigenous within the academy I state autobiographical ethnicity as my research methodology, allowing myself the opportunity to create a hypothetical third space - separate to the binary relationship of authority and status established between Indigenous and non-Indigenous peoples, black and white in current Indigenous studies ${ }^{2}$ and/or critical race theory: ${ }^{3}$ one that is truly reflective and understanding of both Aboriginal and non-Aboriginal and as both the coloniser and the colonised, both 'Black and consummately White' (Lehman, 2004). I understand that this puts me at odds in wanting to become accepted within an Indigenous academy that is clearly subject to misinterpretation and institutional bias (Chalmers, 2005), but I also want to make it clear that personally I do not feel connected to the word 'Indigenous' either, and will instead from this point on when describing my own identity use the words Kamilaroi, First Nation, Aboriginal or Aboriginality, and/or black, white or Pākehā $\bar{A}^{4}$ in describing my own identity. It's a statement I need to make very early, as such terminology becomes problematic and open to interpretation.

Let me explain. Bob Hawke, when Prime Minister of Australia in the 1980s, together with Clyde Holding as Minister for Aboriginal Affairs, changed the terminology of 'Australian Aboriginals' to 'Aboriginal Australians'. This happened without so much as a blip on the radar, but how did this change the meaning of our identity? 'Australian Aboriginals' means that we are Aboriginals albeit from Australia; 'Aboriginal Australians' means that we are Australians (citizens) albeit Aboriginal. Therefore the terminology was not changed as any random act but to instead prioritise our Australian citizenship over and above our Aboriginality. John Howard, then as Australian Prime Minister during the turn of the century, went further with 'Indigenous Australians', then quietly said on radio that everyone born in Australia is Indigenous, a sentiment repeated by ultra-conservative right Australian politician and member of the Senate Pauline Hanson, saying, 'I'm Indigenous, I 
was born here. This is as much my land as any Aboriginal that was born the same date and time as I am' (Hanson, cited in Clarke, 2016). Hanson has also regularly challenged the identity of Aboriginal people who are of mixed race, claiming that those who did not have dark skin and brown eyes could not claim to be Aboriginal, because if they did it was only to receive welfare benefits (Clarke, 2016). Australian Race Discrimination Commissioner Dr Tim Soutphommasane has warned Pauline Hanson, who along with attacking Aboriginal people has also used her public position to regularly cite antiMuslim and Asian rhetoric, and has the potential to unleash hatred, divisions and violence in Australia. Dr Soutphommasane has said there was a sense of 'déjà vu' in her sentiments, pointing to examples overseas, especially in postBrexit Britain and during Donald Trump's bid for the US presidency, showing how such comments can degenerate into abuse and violence (Kennedy, 2016).

Let's heed to lessons of history and not be complacent about the dangers that face us right now. There's great potential for harm to be done when you're talking about inflammatory rhetoric or appeals to xenophobia, they make a sure recipe for hate and division. There is a section of our society that are fearful of cultural change and have concerns about the national identity. By all means, let's hear what the concerns are, but let's do it in a manner that respects fellow Australian citizens and doesn't reduce anyone to the status of an outsider who is unwelcome in Australia.

(Soutphommasane, cited in Kennedy, 2016)

Hanson is not on her own. Andrew Bolt, one of Australia's most-read journalists, who like Hanson is famous for his ultra-conservative views, also claims to be an Indigenous Australian, despite his not having any Aboriginal connection at all.

I AM an indigenous Australian, like millions of other people here, black or white. Take note, Tony Abbott. Think again, you new dividers, before we are on the path to apartheid with your change to our Constitution. I was born here, I live here and I call no other country home. I am therefore indigenous to this land and have as much right as anyone to it. What's more, when I go before the courts I want to be judged as an individual. I do not want different rights according to my class, faith, ancestry, country of birth ... or 'race'.

(Bolt, 2014)

As stated in Romans, chapter 16 verse 19 within the New Testament, we are to 'remain wise in seeking good' and 'remain simple in observing evil' - in applying such philosophy to my own humanity it becomes ever clearer that such hate and division appear to be coming from a privileged group in attacking those who have by no way the same influence or power as a right of 


\section{Yammaa gamilaroi winnunguldah}

reply against those attacking them. Therefore in expressing wisdom in what is good, I write this book simply, not only as a descendant of the Australian Kamilaroi Aboriginal First Nation peoples but also in drawing upon my Irish origins having first been reared as a Pākehā (white person) in Aotearoa (New Zealand). Also in realising that life, in dealing with the evils of such sentiment, is far too complex to be packaged as purely Aboriginal or non-Aboriginal, black or white. In expressing such simplicity as a Pākehā growing up in New Zealand I still remember as a child sitting in the classroom looking around at the Polynesian and Māori kids and thinking to myself how lucky they were that we as Europeans came and found them, and give them civilisation.

Autobiographical ethnicity allows me then a shift from contemporary Indigenous studies, by being separate from - yet experienced in and able to analyse - the systematic evils of colonisation as an Australian Aboriginal who identifies as both black and white, rather than being alienated and subjected by them. It is writing that rather than exclude culture(s) is written from within the author's own reflected ethnicity as part of a universal narrative stated as a process of self-definition, which remains the discussion's objective, and its closing point (Waters, 2012b, p.136). In short - I choose to write from a position that further empowers my own sense of inclusiveness and engagement rather than allowing the rules of the academy or grammar at the interface of white privilege to silence or censor my own voice, which brings me back to the term 'Indigenous'.

As Aboriginal people the term 'Indigenous' as labelled under international legislation (Australia has no treaty or official recognition of Indigenous peoples in the Constitution) is defined as having a set of specific rights, both legally and morally based on their historical ties to a particular territory, and their cultural or historical distinctiveness from other populations (UNESCO, 2016), but Indigenous also determines Aboriginal people and their existence within a Western framework that binds them legally to a process of colonisation. Whereas 'Aboriginal' peoples have no such ties to Western legislative assembly, instead being defined as inhabiting or existing in a land from before the arrival of settler colonies; a time immemorial extending beyond the reach of memory, record or tradition, indefinitely ancient, ancient beyond memory or record (Rothwell, 1996). In law, it means that a property or benefit has been enjoyed for so long that its owner does not have to prove how they came to own it. We are talking about a time before legal history and beyond legal memory. In 1275, by the first Statute of Westminster, the time of memory was limited to the reign of Richard I (Richard the Lionheart), beginning 6 July 1189, the date of the King's accession (Garner, 1987). Since that date, proof of unbroken possession or use of any right made it unnecessary to establish the original grant of title under certain circumstances. This law was maintained in definition and was enforced right through to 1832, long after the British discovery of Australia; meaning as Aboriginal people during the time of first contact we had to maintain traditional sovereignty of our lands beyond the burden of proof as 'time immemorial' remains or legislative or 
historical proof of title - this allows us to argue our land was stolen illegally, whereas our being 'Indigenous' binds us to Western legislation colonisation and having to prove occupancy. Now I know that many conservative commentators like to reference statutes of limitations when acts of illegality and human rights violations are revealed from our past, but let's be honest, or in referencing again Romans chapter 16, verse 19, 'wise' and 'simple', here I am writing 220 years after first contact, still arguing that Aboriginal peoples have a parallel system of knowledge production and organisational structures beyond that understood within the West. Why is that so hard to understand ...? Referendum Council Co-Chair Pat Anderson recently summed up this position when she stated on national Australian television:

We are voiceless and powerless in our own country and we have been here for 60 thousand years. There has to be substantial change, structural change that will make a difference. We been asking for this nothing's new prior to 1840 and no body listens and hears us ... I don't understand that. What is it that we're not saying that you can't understand ...?

(Anderson, 2017)

Why is it that white people have so much difficulty in accepting that we have a completely different way of viewing the world, just as we did over tens of thousands of years before our lands were invaded ...? It's a question that says so much more about white people than it does Aboriginal people. What I have to say is too important, and in wanting to make a contribution of political significance through the act of writing I can no longer afford to remain concerned about what white or non-Aboriginal people think. And in making this decision I overcome the hegemonic control of my Aboriginal voice as previously only seen through a colonial gaze. In writing this book I want to disrupt contemporary white Australian notions of what it means to be Aboriginal and in representing the voice of my people, centre our own narrative at the heart of the discussion. I want to assert our stories of creativity as funds of knowledge worthy of their true intellectual property in providing validation within the context of a global community and engagement outside Australia and the rest of the world. In making the decision to write on behalf of my Aboriginal family and having introduced myself traditionally I cannot afford to then censor myself for fear of offending others - our people, their language and their culture are dying with every word I write and something has to be done. I therefore make a conscious decision to write in a very personalised subjective account (Kane, 1988, p.240), in introducing autobiographical ethnicity as my methodology. As discussed previously, in having introduced autobiographical ethnicity as my narrative I allow myself the opportunity to create a hypothetical academic, cultural and creative third space as a conscious shift away from contemporary Indigenous binary structures that continue to censor our Aboriginal voice today as in the past. Throughout the book you will read as I examine the complexities of these 
hegemonic binaries that impact upon Aboriginal knowledge production not as an observer but within the privileged space of my own understanding as a yuuray mandhiigan (fully initiated Kamilaroi language speaker and ceremonial keeper). In striving for equity, my aim is to continually recognise and challenge the binaries that privilege some agendas and marginalise others. Autobiographical ethnicity focuses on the similarities and differences associated with the concepts of identity, identifying and binaries between the knowledge production of Western hegemonic practices and First Nation peoples. Therefore I make a conscious decision to move from critique to project, from negative to positive deconstruction as separate and yet equal to each other, in order to return Indigenous writing back towards Aboriginal consciousness in such a way that allows for a move beyond the binary of hegemonic Western practice and its associated power relations.

My personal statement as a writer then reads:

My writing engineers a hypothetical cultural and creative third space in reinventing the position of Aboriginal peoples beyond its current binary in wanting to picture events over time and space around me, in returning to the past and seeing my future, to remember the sound of ceremony and the laughter of children before the impending silence broken by colonisation.

(Dr Marcus Woolombi Waters)

As Aboriginal people it has become time to reject the assumption that as a culture and as a people we remain inferior to the West. A position supported by Dr Maybury-Lewis:

We can no longer assume, if we are fortunate enough to live in one of the 'developed' countries, that our way of life represents the most advanced stage of progress over and that other societies have simply been less successful than ours in attaining it. Instead, we know that other societies have made other choices, followed different paths in search of different destinies. This knowledge opens up new vistas on the richness and variety of what it means to be human. The challenge we all face is how to come to terms with these differences, how to live with the variety, now that we have discovered that there are more things in heaven and earth than were dreamt of in our philosophy.

(Maybury-Lewis, 1992, p.198)

It is only human to see everything through one's own lived experience but as long as the ultimate goal becomes the celebration and survival of our humanity then we need to mend these bridges between ourselves first before moving into the future together. And this healing has to start with the acknowledgment of trauma, theft and legacy of colonisation in prioritising our Aboriginality above all else in realising that at some point, no matter 
how distant, or how long ago each and every one of us, Indigenous or nonIndigenous, Aboriginal or non-Aboriginal, white or black, we were all at one time Aboriginal. As hard as it is for some to accept, it is not civilisation that links our humanity, but instead our Aboriginality that links our humanity; it is our civilisation that instead divides us and keeps us separated, built on the fear and hate of the other. We all need to ask ourselves what legacy we want to leave our great grandchildren of the future: more trauma, more abuse, more division, or instead do we now contribute to a process of healing?

To help aid in this process we need to move beyond the colonial gaze established from settler colonies embedded deep within our institutions of learning. We need to break down the walls that maintain these power structures based on privilege, which perpetuates and marginalises people of colour as acknowledged in critical race theory. Autobiographical ethnicity becoming a tool for simplicity and wisdom applied as a form of creative scholarship bringing together ethnicity and life journey as interdisciplinary practice taken from aspects of sociology, history, philosophy, science and legal studies far beyond the scope of current Indigenous studies applied within humanities.

The problem is, and always has been, that in citing my authority as a Kamilaroi ceremonial keeper and language speaker my reference base in the past has become limited through the very Indigenous studies that was meant to free us. The reality is that knowledge of Kamilaroi becomes grounded in metaphysics in dealing with the first principles of 'all things'. This is methodology in thought, including abstract concepts such as being, knowing, identity, time and space. Now I am more than aware that such philosophy may be dismissed by market neoliberalism as abstract theory with no basis in reality but again ask yourself who is set to gain from limiting the human mind in not accepting or understanding that all things are perhaps in some way interrelated ...? The unique position I represent as a yuuray mandhiigan (fully initiated Kamilaroi language speaker and ceremonial keeper) tells me, no, shows me ... that for many Aboriginal people we regard this question as a first consciousness of understanding tied to creation and the universe as essential to our belonging. This understanding, or better winanga-y-la-nhi (consciousness ...) is founded in our belief system connected to the realm of Burruguu-ngayi-li, or 'Dreaming'. This concept then becomes the very basis of our reality prior to, during and beyond the act of colonisation.

the Aborigines believed that the universe has two aspects. There is the ordinary physical world in which they live and another connected world from which it is derived. This other world, called the dreamtime, or the dreaming, is the major focus of Aboriginal thought, because the principles and powers emanating from it determine what happens in this world.

(Maybury-Lewis, 1992, p.197)

Creation theorist Rob Pope then takes this concept even further, discussing the unique sense of interrelatedness understood as traditional Aboriginal 
pedagogy which incorporates epistemology based in a circular and non-linear notion of life and experience (worldview, or ontology), as opposed to the way many non-Aboriginal or Western people think:

the distinction is an important one. Plato's image of the magnet suggests a one-way transmission of energy from a divine source through physical and human intermediaries to the audience. His is essentially a monologic, top-down model of the inspirational process. That of the Aboriginal elder is more dynamic and dialogic. It involves two- and many-way flows of energy, and, through them, kinds of reciprocal support and interanimation. Clearly, then, a lot depends upon the precise process of inspiration; who or what is reckoned to be 'breathing into' whom or what, through what means, and with what effects.

(Pope, 2005, p.92)

So again, in avoiding the sophistication that derives hate and fear for the other within modern civilisation and instead becoming wise and simple in our approach - what really separates Aboriginality from the West is based on understanding the inter-relatedness of all things which for Aboriginal people brings together ways of knowing, ways of being, and ways of doing (Martin, 2008). This interconnection is what at present retains our separation and uniqueness from non-Aboriginal approaches to Western knowledge production. Unfortunately, the result of such separation contributes also to gaps in education, health, and financial emotional stability essential to wellbeing. As one culture thrives centred on individualism, materialism and ownership, the other remains disconnected and isolated in an environment that just doesn't cater to the needs of their collective. As the dominant culture appears to be more successful these are circumstances that do not look like they're about to change anytime soon.

Particularly as David Maybury-Lewis alludes to the near impossibility of many non-Aboriginal people ever comprehending Aboriginal knowledge systems when he writes: 'It is hardly surprising, then, that a well-known Aboriginal artist, Bunduk Marika, said recently and most emphatically, that white people would never understand the dreaming' (Maybury-Lewis, 1992, p.197). Having accomplished a $\mathrm{PhD}$ myself and knowing personally the sacrifice and investment it takes, the last thing I want to do is now take on three, four or five $\mathrm{PhDs}$ in other disciplines so I can adequately interpret my Aboriginality in Western terms.

The key question then upon the completion of my $\mathrm{PhD}$ was whether such Aboriginal epistemology I had retained as a member of my community could be nurtured into the future, as many other 'Indigenous scholars [who] join the Academy and what was once unique in [their] cultural practice becomes embedded outside of our [their] own cultural space' (Waters, 2016a, p.21). We must take notice of, and position strategically, the traditional strength of the now isolated parallel tradition (the 'other side' of the binary) and importantly, 
ensure it is no longer relegated to an inferior position. As there is no clear definition, in either the Western academy or in contemporary Indigenous studies, which adequately describes my own form of research and storytelling practice, in completing my $\mathrm{PhD}$ I was forced to break down current ethnographic forms of writing while introducing autobiographical ethnicity as my research methodology. The following is an excerpt taken from this same $\mathrm{PhD}$ (Waters, 2012b, pp.137-139), which breaks down and gives a critique of current academic practice regarding a number of autobiographical narratives currently used within the study of social sciences and humanities:

Etymologically, the term autobiography is derived from the Greek auto (self), bio (life) and graphein (to write). Autobiographic writing was located within the Late Latin category of apologia. Apologias are statements 'in defence of one's opinions, position or actions' (MerriamWebster Dictionary). The term ethnicity is commonly used in national population demographics to categorise people on the basis of heritage 'a group of people who have the same culture and tradition' (Macmillan Dictionary). Ethnography is the term used to describe a qualitative research method as stated previously; predominantly used by anthropologists - whereby 'data' takes the form of field notes and/or audiovisual documentation derived from the researcher's close observation of peoples and immersion in their daily lives. This term has been co-opted by researchers from the Humanities and Social Sciences undertaking autobiographical projects to create the conjoined term 'auto-ethnography'. In the 1960s, theorists of social interaction focused attention on the role of language in the creation of social order, i.e. the collective adoption and internalisation of commonly shared values and norms. A new school of thought known as Ethnomethodology arose out of the work of Harold Garfinkel who critically evaluated the documentary process, arguing for deeper analysis, adding a greater layer of complexity to the idea that a person became a member of a group by virtue of their aptitude for language and sense-making. Garfinkel explained:

the method consists of treating an actual appearance as 'the document of', as 'pointing to', as 'standing on behalf of' a presupposed underlying pattern. Not only is the underlying pattern derived from its individual documentary evidences, but the individual documentary evidences, in their turn, are interpreted on the basis of 'what is known' about the underlying pattern. Each is used to elaborate the other.

(Garfinkel, 1967, p.78)

This definition of the documentary process provides for the view that members of a society do not make sense of actual actions in daily social life by simply perceiving them as they currently appear. Instead, it assumes that particular actions can only be interpreted as recognisable by reflexively drawing on past (and then future) 'appearances-of-familiar-events' (Garfinkel, 
1967, p.78). The method for collecting data in an ethnographic study is direct, first-hand observation of daily participation, along with in situ participant input, where participant voices do not have the mobility to be otherwise heard. Autobiographical narratives that find publication can operate similarly (Sparkes, 2002, p.209). Writing about the autobiographical voices of those who do not recognise themselves in the traditional images that literature and society project and uphold as models, Françoise Lionnet proposes that

the self engendered on the page allows the writer to subject a great deal of her ordinary experience to new scrutiny and to show that the polarity fact/fiction does not establish and constitute absolute categories of feeling and perceiving reality. The narrative text epitomizes this duality in its splitting of the subject of discourse into a narrating self and an experiencing self which can never coincide exactly.

(Lionnet, 1989, p.92)

Lionnet suggests 'self-portrait' is a more effective generic term (than autobiography) because it avoids 'the scepticism with which contemporary literary theory has taught us to view any effort of self-representation in language' (Lionnet, 1989, p.98). To underscore this point, Lionnet refers to Zora Neale Hurston's autobiographical Dust Tracks on a Road (1942), which although informed by fieldwork designed to 'salvage her own vanishing Negro culture', because it did not demonstrate 'race solidarity', was perceived as 'insincere and untrustworthy'. In Lionnet's view, the term 'authoethnography' is more suited to works that define 'one's subjective ethnicity as mediated through language, history, and ethnographical analysis, in short ... a kind of "figural anthropology of the self"' (Lionnet, 1989, p.99).

My position in remaining true to surviving parallel Aboriginal knowledge production outside of the process of colonisation draws on both autobiographical writing and ethnicity represented best as a living, breathing Aboriginal epistemology defined as 'a working basis for applied Aboriginal pedagogy' (Waters, 2012b, p.139), practised as traditional Kamilaroi storytelling dating back tens of thousands of years. In order to remove the binary relationship of hierarchy and opposition evident in current Indigenous scholarship, my research first addresses 'that definitive point' which constitutes Aboriginal pedagogy. It is a journey that has been encouraged by those close to me whom I respect the most, such as in e-mail correspondence with a true mentor and friend, Professor Boni Robertson, an Australian Dauwa Kabi Kabi First Nation Aboriginal woman:

You should be proud of the work that you are doing, Marcus. You are articulating in a contextual and practical way, what is known to us to be our cultural framework, that defines externally and internally who we are as Aboriginal people.

(Robertson, 2009) 
For autobiographical ethnicity to maintain continuity and authenticity with traditional practice, it remains necessary to define Aboriginal pedagogy in such a way that it becomes cognitively inherent to all that is Aboriginal and understood within Aboriginal epistemology, but also seen as parallel and equal to a non-Aboriginal research methodology. My strategy to overcome the current academic ambiguity of what constitutes Aboriginal epistemology (and, by implication, Aboriginal identity) utilises interviewing, story-sharing and an autobiographical rhetorical construction,

a self for public, not private, purposes: the displayed self is a strategically fabricated performance, one which stages a useful identity, an identity which can be put to work. It is the quality of that usefulness which determines the politics of autobiographical discourse. In other words, what is the identity being put forward for?

(Ang, 2001, p.24)

This construction acknowledges my Aboriginality as inherent, as understood within my family network. Thus my research involves the sharing of stories and lived experiences - Aboriginal and non-Aboriginal, their collection and analysis. The narrative voice in my writing utilises my own requisition of a traditional Kamilaroi Aboriginal language base as a viable alternative: not only as a statement of my authority to speak as an Australian Kamilaroi First Nation Aboriginal but also in introducing a notion of interconnection between two worlds. The combination of effects derived from traditional ceremony and storytelling together with academic writing seems to me the ideal way of introducing a new set of knowledges, as a conduit between cultures currently denied within the academy.

in an era when the diversity of human experience in social groups and communities, with languages and epistemologies, is undergoing profound cultural and political shifts. Although it could be argued that this has always been the case because societies always are dynamic, there is an argument to be made about the rapid loss of languages and cultures through globalization and the significance for many communities of the impact of human beings on the environment. Indigenous communities live with the urgency that these challenges present to the world and have sought through international mobilization, to call attention to these concerns. It is considered a sign of success when the Western world, through one of its institutions, pauses even momentarily to consider an alternative possibility. Indigenous research actively seeks to extend that momentary pause into genuine engagement with Indigenous communities and alternative ways of seeking to live with and in the world.

(Tuhiwai Smith, 2005, p.104) 
In accepting that Aboriginal and Western knowledge productions remain separate and yet equal to each other, we are able to recognise a parallel tradition of intellectual development (Aboriginal and non-Aboriginal) beyond that which is connected to an act of colonisation.

Whether you are Australian Aboriginal or from a non-Aboriginal heritage, your peoples' quest for knowledge began a very long time ago. Whether looking up at the stars, or sitting around a fire looking deep into its flames we all began telling stories in wanting to make sense of our place in the world.

(Sammel \& Waters, 2014, p.1237)

Whether we wrote the ideas down, printed in books or retained them through ceremony, rock art, dance and oral histories, we all carried this knowledge generation after generation. What overrides respect and acknowledgement of these parallel journeys is the even greater concept of 'binary' in opposition of cultures via a process of colonisation. Autobiographical ethnicity overcomes this in that it acknowledges the life story and ethnicity of the writer, not in such a way to exclude non-Aboriginal writers but to ask them to state their connection, their engagement and why as non-Aboriginal writers they have chosen to contribute to Aboriginal studies.

Such strategy, I believe, will allow Aboriginal knowledge production to move beyond the process of colonisation, that in acknowledging the autobiography and ethnicity of the writer we unsettle the power hierarchy that exists within the binary of the present relationship between Aboriginal and non-Aboriginal, Indigenous and non-Indigenous, black and white that currently divides Western knowledge production as it remains unspoken, the writer hiding behind the hegemony of academic practice. Such a strategy would create equalising recognition of differences through at least initially the incorporation of similarities rather than opposition between Aboriginal and non-Aboriginal intellectual property.

This would allow the operations of culture, science and art that criss-cross the Aboriginal and non-Aboriginal academies of learning to flourish and become multidisciplinary - beyond the current limited status of Indigenous scholarship associated with the necessarily reductive strategies of surviving colonisation.

(Waters, 2012b, p.119)

Autobiographical ethnicity is then established in order to provide my people with a voice previously silenced not only within the Western academy, but also the media and popular culture. When applying autobiographical ethnicity I write objectively, utilising rhetorical construction of my own lived ethnic experiences as an Australian Kamilaroi Aboriginal. As the writer I become a visual camera, recording subjectively, no longer just an impartial 
observer, but rather via emotive physical description a highly personalised account of history, past and present, engaging in overtones of value and meaning that through feeling and colour giving privileged access by the reader to my life as an Australian Aboriginal. Rather than exclude the nonAboriginal writer, autobiographical ethnicity creates a partnership in better understanding the motivations of, and in creating empathy with, Aboriginal and non-Aboriginal writers in fashioning highly personalised subjective accounts as accurate readings of history.

Personally I grew up believing my grandparents to be my parents until the death of my Pākehā grandfather/father in New Zealand when I was 12 years old. This knowledge that I was indeed a 'black Australian' with an Aboriginal mother and extended family pushed me into a state of rebellion and a desire to seek the truth and validate my existence towards now becoming an Australian Aboriginal. It was here the seeds for this book were first planted deep in my unconscious mind. It is a journey that has led me from the emotionally tumultuous state of my adolescence to the firm resolve of responsibilities of adulthood. Below is another excerpt taken from my $\mathrm{PhD}$ in describing my being introduced to my Aboriginal consciousness via a process of trauma written as autobiographical ethnicity in its purest form (Waters, 2012b, pp.217-219).

In my case, I missed the formal introduction to my Indigenous epistemology, having been removed at birth; therefore my introduction to my Aboriginality was not as coherent, nor in such a controlled nurturing environment. Nonetheless, it still had tremendous impact upon my life. I remember the birth of my own Aboriginal consciousness as if it was yesterday. Interestingly it occurred years before being introduced to my Aboriginal mother while still living in New Zealand. I was four years old when I walked into the well-kept lounge room of my working-class Pākehā home in New Zealand. I looked over at my mother, in her mid sixties, a person I loved dearly. She smiled back at me as she sat on the lounge sewing and watching television. I turned to the TV screen and was amazed to see these black, and what I thought were handsome, athletic men engaged in some strange, compelling and yet bizarre tribal dance. Like many four-year-old white kids around the world who witnessed this fantastic dance, I broke into stride without hesitation. 'Weeeyyooouuu Eeeyyoooouuuu', I wailed as my feet slammed and stomped against the thick, warm carpet and my legs shook together like the dark handsome beautiful men on the television. I then turned back to look at my mother, wanting to ensure she was watching as I discovered this new God-given talent - as four year olds do. But it was not my mother instead it was my enraged father Brian I saw charging at me! I froze. Like many other Irish children born to the late 1960s, this was not the first time I was to witness such fury from 'the old man'. What was different about this beating though, was the lack of explanation about why it happened. There was 
no 'cursing' and no 'being told repeatedly what I had done wrong', just a savage beating. My head slammed against the brick mantelpiece that framed the open fire responsible for the beautiful warm carpet and the security I felt only seconds earlier. And then I found myself locked in a cupboard, sobbing and crying. This was to be my introduction to life, family and love in my formative years. This time, though, my mother didn't come to rescue me as she had done on so many other occasions. Normally after some time the door would open and there would be my loving mother, with cookies, milk and a hug. And an explanation of what I had done so wrong and why I had enraged my father so. But this time she did not come to open the door. I closed my eyes and went to sleep. When I woke, it must have been very late, because the cupboard had gone from dark to black. I couldn't even see my hand in front of my face. I had never been left for so long before ... that's when I knew that this must have been a very special beating.

What occurred that day for me is demonstration of my own 'space-time continuum', interpreted as a critical moment in my life. The trauma of the encounter acted as a conduit between my unconscious and conscious minds, as part of my emerging awareness of the relationship between time and place. In my Irish grandfather's eyes I had committed an 'unspeakable' act in dancing like the Aborigines I witnessed on the television. The fact that my Irish grandmother did not come to me later was also significant in my developing an awareness that I would later realise as my having given birth to my 'contemporary Aboriginal consciousness' (Anderson, 2003, p.21) - a consciousness born from notions of disadvantage, social inequity, devastation, and being endangered and dispossessed.

As an Aboriginal parent, I can no longer carry the pain of my trauma into my future and hopefully in now writing this book I make an active contribution to my own process of healing. Rather than being bound, I free myself via autobiographical ethnicity to accept the privileged world of academia, where unlike others who remain voiceless I now have the agency to utilise the tools of qualitative research in investigating my heritage and exploring the subjectivities that have intersected my life. I have the opportunity to position and locate myself beyond a world where injustice and inequity characterise the existence of Aboriginal peoples within our own country - where hopefully my writing will empower others. Application of autobiographical ethnicity as my research methodology allows for both my Aboriginal knowledge base and my understanding of academic structure and critique to become merged into the one organic piece of work compiled as interdisciplinary in its approach. Long after being beaten into an Aboriginal consciousness, taken from my Aboriginal mother, my research methodology began considering contemporary academic discourses on Aboriginal subjectivity and in wanting to explore how 'Indigenous' people identify and debate the nature of their own Aboriginal consciousness which has brought me to where I am today. This 
book, my own personal journey inspired by the legacy of conversations taken place within my own family over tens of thousands of years, generation upon generation, which bore fruit to the foundations of my own Aboriginal identity ... giyaan nginda winanga-y yuwayaa wuurriyala-y (can you imagine any greater privilege ...)?

\section{Notes}

1 Welcome to Country has been a part of Australian Aboriginal culture for thousands of years. Aboriginal Nations had clear boundaries established by clan, language and kinship groups, and entry into another person's traditional lands needed their permission. When permission was granted the traditional owners of the land would welcome the visitors, offering them safe passage and protection in acknowledgment of not only those living but also their ancestors. This would often be done with a traditional corroboree, a traditional dance ceremony taking the form of a sacred ritual or gathering. The visitors would respond with a dance of their own in agreement to respect the protocols and law of the traditional landowner group while on their sacred lands. Today, these protocols have been adapted to contemporary circumstances where the essential elements of welcoming visitors and offering safe passage remain in place. A Welcome to Country occurs at the beginning of a formal event and can take many forms including singing, dancing, smoking ceremonies or a speech in either traditional Aboriginal language or in English.

2 The first university in Australia was founded in 1850. It was not until the 1970s that Aboriginal Australians gained access to Australian higher education under the banner of mass higher education allowing those previously excluded from higher education to be given access. Today, Aboriginal and Torres Strait Islander involvement in educational decision-making, and the policy of closing the gap of equality for access and participation as compared with other Australians, are seen as appropriate educational outcomes for Indigenous people. To achieve these goals, universities have established a range of Indigenous units, such as advisory boards, councils and centres funded by government tied to key performance indicators established not by Aboriginal communities but government and university funding. These are what I call the 'Indigenous Academy' - that is, networks of Indigenous academic staff groups working within universities funded by government outside their own community structures - and these are the groups that drive current Indigenous studies within Australia.

3 Critical Race Theory acknowledges racism as institutionalised, engrained in the fabric and system of white supremacy that benefits one group over the diversity of others. It identifies that these power structures are based on white privilege, which perpetuates and marginalises people of colour. Critical Race Theory focuses on structures of law and traditions through history that have contributed to the unbalance of equality contributing to contemporary societies, the lived experiences and racial sensibilities of racial minorities throughout the West.

4 Māori, Aotearoa (New Zealand) Aboriginal word for white, or of European descent originally applied to English-speaking Europeans living in Aotearoa/New Zealand. 


\section{Gamil bida-wii (Before the beginning ...)}

Our peoples have left with us deep roots which have empowered us to endure the violence of oppression. They are the roots of survival but not constriction. They are the roots from which all growth is possible. They are the roots that protected our end from the beginning.

- Michael Dodson

After enrolling in university studies through an Indigenous unit, rather than confirm what I thought I already knew, that our Aboriginal knowledge base had remained as a distinct and tangible pedagogy having outlasted colonisation, I was instead drawn to conceptions of "Indigeneity' as an established agency situated within the academy - the term provided personal agency that co-existed outside the realms of my own prior knowledge and beliefs as an Aboriginal language speaker and writer. This created conflict where in wanting to establish possibilities for a new theoretical and conceptual framework for an Indigenous pedagogy that gave authentic voice to our people (Waters, 2013), I found the most difficult obstacles came from this newly formed Indigenous academy of which I was now part ... It was devastating, it was here that I first met Aboriginal people who could not readily identify with traditional kinship ties or distinct Aboriginal communities; these were people who had been denied access to their own languages and cultural practices. In attempting to reaffirm their position I quickly realised that within the academy we had relied too much on notions of cultural identity based in historical essentialist constructs - fantasies of exclusivity, cultural marginality, heightened physicality and morality in the creation of a binary oppositional relationship between Indigenous and non-Indigenous scholarship rather than embrace the timeless history of our own Aboriginal communities. It was a strategy for surviving the process of colonisation. In many ways these educated blacks, Indigenous Aboriginals, were only dealing with what they knew ... an Australia embroiled in racial conflict after the European arrival. I was not only blessed but privileged in having access to my identity long before the invasion. I realised this time before the beginning had to become the focus of my research in search of something more authentic and productive than victims of colonisation - a vision that would allow us to throw off the status of victim 
and rise to the position of first citizens and primary caretakers of a greater Australian Aboriginal consciousness. It was here that my own Indigenous knowledge base embedded deep within my own Kamilaroi initiation rites became challenged as the academic writing began to merge within my own Aboriginal consciousness. I realised then and there that rather than free our voice, Indigeneity formed from within the academy to elicit an approach to Aboriginality as a collective agency only formed deeper the binary of colonisation at the interface of Western and Aboriginal knowledge production. The answer become a return to my Aboriginality based upon interdisciplinary practice formed over tens of thousands of years and whose lived realities and subjectivities did not align with (anti/post-)colonial constructions no longer vulnerable to accusations of inauthenticity (i.e., of not being 'real' blackfellas; of not being seen as an authentic Aboriginal) (Paradies, 2006).

My research then as a written text began exploring the tensions created through the contemporary Indigenous deconstruction of our own historical consciousness, particularly as urban, educated Indigenous scholars began to assert their individual identities over traditional practice and ongoing cultural maintenance. It was here that I found the most effective strategy was in my returning constantly to the intuitive third space between Aboriginal and nonAboriginal, black and white, through an interplay between the sensibilities of narrator-character and audience. I had started to develop autobiographical ethnicity as an alternative, non-essentialising, contemporary relationship to history and place, and the formation of interdisciplinary Aboriginal subjectivities. As these were educated Indigenous blacks who were now alienating me I was reminded, as I wrote earlier in the first chapter of this book, that such sentiment is far too complex to be packaged as purely Aboriginal or non-Aboriginal, black or white. I had to acknowledge that throughout my life journey, even as Kamilaroi I had been influenced by both Aboriginal and non-Aboriginal, black and white authors of the past and present who had contributed significantly to my own understanding of blackness, Aboriginality and yes ... my very humanity.

In acknowledgment of this outcome, a conscious decision was made to move away from autoethnography as a previous Indigenous autobiographical practice as I was interested more in an inclusive interdisciplinary practice, and autoethnography had become more 'reflective of the discontentment of traditional research practices' (Houston, 2007, p.41) I had encountered within the academy. My research methodology become an example of a research-based practice in returning once again to this parallel third space that gave recognition and acknowledgement of 'black' and 'white', and the universe of difference around them. It was here in between the binary of opposition within this third space that defined our humanity I had now discovered 'autobiographical ethnicity'. Inspired, I can now move forward embedding traditional Aboriginal storytelling with academic scholarship and rigour, engaging with my audience through actual historical characters and real stories that have inspired me throughout my life, contained as amalgamations and 
elaborations of historical persons and constructions. Therefore I have utilised the term 'autobiographical ethnicity' to encapsulate fact, fiction and other possibilities based in Aboriginal and non-Aboriginal historical and contemporary interactions that draw upon my own lived experience as an Australian Kamilaroi First Nation Aboriginal: encompassing the generations before me as part of my own family's inherent Aboriginal knowledge base. Rather than a hybrid or an extension of something else I became immersed as part of a nhuubala Burruguu-ngayi-li (new Dreaming). No longer a victim, I had found a lifeline running parallel and separate to a process of colonisation: I was no longer bound or censored by my past; it had instead become my strength.

I am no victim of colonisation nor do I espouse such philosophy - martyrdom has no long-term future for anyone. We are survivors enduring and ancient who maintain a fight for justice and truth. What I want to see is Aboriginal languages acknowledged and our history prior to colonisation taught to generate better understanding and inclusive practice between Australian Aboriginal and non-Aboriginal peoples. I want our Aboriginal children to know who they are and feel proud about their achievements in connection with their true origins. Not as an enslaved people victim to colonisation, but as enduring, innovative and continually evolving. We are not dysfunctional child abusers who beat our women as portrayed by the Western media, the government and education systems. Yes, our trauma is deep, it is intergenerational, it is historical and it resides deeply in the present; but we are not our trauma ... we are so much more. Again I turn to an excerpt taken from my PhD (Waters, 2012b, pp.206-207): It was within my old stomping ground of Aboriginal public housing in Inala, the outer suburbs of Brisbane in Queensland, Australia, where I developed my own sense of Aboriginality. It was my Uncle Paul Spearim, my mother's first cousin, who first taught me my Murraan.gali Yuurrama-y Corroboree (Traditional Dance) and introduced me to notions of Burruguu-ngayi-li (the Dreaming as philosophy and organisational behaviour). It was here that my Uncle Reg Knox, my grandfather's first cousin, taught me my language (Kamilaroi, Gamilaroi and Gamilaraay dialects); and it was my Uncle Marshall Bell, buruwi-y gaba binaal-ga 'rest in peace', who took me to my first Traditional Yammaa Yuligi Wuyugi-li (Initiation Ceremony) in Taroom, Western Queensland, and helped me to connect the dance to the language and the stories of my past.

Each transition is significant in the processes of an established and formalised Aboriginal pedagogy that remains the solid foundation of my Kamilaroi Aboriginal identity. What differs between these moments and those discussed within the confines of the Western academy, government and popular media as a process of reconciliation between Australian Aboriginal and non-Aboriginal people, is that each of these men mentioned is part of my own immediate family and their teaching connects personally to kinship ties and cultural practices tens of thousands of years old. Outside of these kinship systems 'Indigeneity', whether or not represented by Aboriginal people 
themselves, is being removed from our own 'unique cultural space' (Sammel \& Waters, 2014, p.1243); and it is in this 'un-cultural space' where acknowledgement of Australian Aboriginal identity has always been through Indigenous and non-Aboriginal construction and misrepresentation. The problem I have found is that rather than fight for equality where not only our people are given opportunity, but also the culture, worldview and communities they represent are also acknowledged as funds of knowledge, instead we are witnessing a process of equity where participation and access are seen as enough - in institutions that are already based on hegemonic bias that marginalise some and privilege others through misrepresentation and misinterpretation, and such policy only maintains the entrenched power balance. There are times when you just have to acknowledge that the very foundations of the system you have built are rotten and need to be cleaned out.

Indigenous peoples have had a long history of (miss)-representation by non-Indigenous people. For a great number of years since invasion Indigenous peoples were supposedly 'known' by non-Indigenous people as 'primitive' peoples; peoples who were lower down on the (their) social and biological hierarchy; people who were more like animals than human beings. This representation underpinned the way British (and subsequently Australians) were to relate to Indigenous peoples.

(Chalmers, 2005, p.151)

In having to deconstruct non-Indigenous misrepresentations of Indigeneity it has taken a long time for me to fully incorporate what my uncles taught me, as my own rite of passage as Kamilaroi is no longer connected to a panAboriginal national consensus of defined Indigenous epistemology - where access to the academy and issues of equity, participation and access over equality are having a detrimental effect towards maintaining an Aboriginal identity. These strong, cultured, highly distinguished and respected Kamilaroi men who taught me my language, culture and ceremony have been let down. Rather than a sense of collective identity, solidarity or unity since access was granted within the Indigenous academy and other employment opportunities through identified 'Indigenous' positions, there appears an increased culture of division, seclusion and alienation bordering on lateral violence (Australian Human Rights Commission, 2011) by those who have not only taken the opportunity, but now want to hold on to these positions and in particular the personal agency they provide within a Western institution. Rather than a vibrant renaissance of traditional Aboriginal culture and values, we are witnessing the pastoral care of Indigenous peoples towards assimilation into Western values at the expense of Aboriginal knowledge production and cultural maintenance where the term 'equity' has all but replaced a policy of assimilation. 
'neoliberalism' recognises no tension between equality and equity: it is all about assimilation, mainstreaming, integration and normalisation. There is little room for cultural diversity and difference or for engagement with democratically elected Indigenous voices.

(Altman, 2013, p.12)

It has only been through the recent intervention dating back to the 1970s of these 'un-cultural spaces', where our people have been given access to mass higher education and employment opportunities within the Australian government public service system (Augoustinos et al., 1999, p.353), that we now find ourselves fighting more than ever to retain ritual and ceremonial connection with our past. As the unique position we once held as Aboriginal peoples becomes blurred in that we now experience the world from a position that is no longer seen as purely Aboriginal or non-Aboriginal (Cowlishaw, 2004, pp.70-71), where 'Traditional Aboriginal' has become a dirty term ironically, a symbol of dispossession (Morrissey, 2003). The rituals and ceremonies, maintained throughout the darkest periods of our history, that made us unique and privileged in our Aboriginality, that defined our humanity, are becoming lost in now being given access to the Western world.

And so here I am, as one of the privileged, who ... yes, did take advantage of these same opportunities coming towards the end of a personal journey that has dominated the adult period of my life - writing almost in desperation to keep my culture alive. My journey into academia began as an inquiry into genetic memory and collective consciousness as essential elements in understanding the Burruguu-ngayi-li or 'Aboriginal Dreaming' - but instead I find myself fighting for my own cultural survival. After having survived tens of thousands of years, in which we charted the universe, recording changes in star positions due to stellar proper motion and precession (Hamacher, 2014), recorded raising sea levels after the last ice age (Reid \& Dunn, 2013), and demonstrated extraordinary innovation and survival in maintaining among human civilisations arguably the longest ongoing cultural connection to land on the planet, well over 60,000 years (Clarkson et al., 2017, p.309) - the advent of mass higher education that allowed Aboriginal people access to the university system and the public service back in the 1970s has had a devastating effect upon Aboriginal pedagogy and accompanying epistemologies. How could this be ...? It is important for the pedagogy of any culture that they are able to articulate in a contextual and practical way what is known as a cultural framework that defines externally and internally who they are and what they represent in order for epistemologies to survive, and this is now being challenged by the universities. Much has changed since I was an Aboriginal teenager growing up in public housing during the 1980s. As little as 30 years ago we had retained ownership in our own identity by defining the States and Territory boundaries within our own language in becoming Murri (Queensland), Koori (New South Wales), Nunga (South Australia), Noongar (Victoria and parts of Western Australia), Yamatji (Western Australia), 
Palawa (Tasmania) and Yolngu (eastern and central Arnhem Land), Bininj (western Arnhem Land) in the Northern Territory. This demonstrated a surviving, adapting and evolving culture, as prior to colonisation there were no words to define the newly formed States and Territories established through these settler colonies. After the advent of mass higher education, educational centres and public services had to accommodate the influx of Aboriginal Australians into their organisations and structures, and in having to be managed into mainstream institutionalised structures we were then labelled as Aboriginal and Torres Strait Islander people, losing our autonomy in selfidentification - an identity so misappropriated we have even been referred to within the acronym ATSI people (Cunningham, \& Baeza, 2005).

Up until this period our epistemologies had remained self-contained within our own communities, running separate to and parallel to the higher education system. The crisis is so great that now less than 50 years since being given access to this 'un-cultural space' as an Australian Kamilaroi Aboriginal First Nation person I remain in the last 11 per cent of my own Aboriginal people who have retained their traditional languages and still speak them at home (Australian Bureau of Statistics, 2011). I therefore write this book possessing a uniquely privileged access independent from 'Indigenous others' who write from the 'colonial gaze', as I write from my own 'Traditional Aboriginal gaze' in having retained my own language, ceremony and cultural practice prior to a process of colonisation. I position myself both from within and outside the 'newly formed' 'Indigenous academy' - and make no mistake, after maintaining an ongoing connection dating back over 60,000 years we are discussing a very recent history, in reality a blink in time eternal and as Aboriginal people we sometimes forget that. When discussing the Indigenous academy, or indeed Indigenous studies, we must also consider the very low numbers of Indigenous PhDs in Australia, with only 260 doctorates obtained by Indigenous people since Indigenous records were first kept in 1986. A great majority of these doctorates (215) have also only been completed since 2001. Of these 215 there have been 50 completed by course work and 165 completed by research (Department of Education, Employment and Workplace Relations, 2010). The evidence then is clear, and without question ... we can't allow something so recent and limited in its collective intellectual property to continue to have the influence it does. We are blessed as Kamilaroi in never having to question our own inherent epistemology - which is why I found myself curious as to why my Indigenous colleagues remain so ambiguous when defining their own Traditional Indigenous pedagogy within the confines of the Western academy, not aware at the time just how much damage had been done to the generic thread of practice and ceremony to other Aboriginal nations due to a process of colonisation.

Years later, my eyes now open and having observed this interface while holding on to my own Aboriginal practice, it becomes clear that the academy is working in partnership with government and popular media to censor our people and maintain assimilation as the prominent strategy within 


\section{Gamil bida-wii}

contemporary society (Leonard \& Mercier, 2015, p.219). Leonard and Mercier go even further than my own position, hesitating to refer to Aboriginal knowledges as a third/or hybrid space, instead choosing to identify Aboriginal knowledges as a 'privileged space', fundamental to epistemologies, ontologies and axiologies (2015) as yet to be fully acknowledged within the Western academy. Honestly in now writing this book, I tend to agree with them. They also view these spaces as centred, 'yet fluid, situated, grounded and rightful' in referencing (Brayboy, 2005); they argue that Indigenous knowledges interfaced within the academy do not necessarily generate knowledge that is integrated or hybridised in nature (Hikuroa, 2009). It is such rationale which again justifies my critique of Indigeneity and my support of Aboriginality as a preferred and more authentic term of reference. The problem is clear and I say it again: in moving out from within our own cultural space, no matter the motivation or intent, once we encompass the historical bias and racism embedded within the institution we are forced to comply in becoming accepted. If we do not comply, we are not accepted and remain marginalised in construction as the 'other', which in itself sums up the problem with equality over equity - why would we as Aboriginal peoples want to join a system that oppresses our people, our culture and our communities? This 'other' is constructed within Western institutions as in deficit, weaker, as being different and/or as a threat (Mander et al., 2011). This framing as deficit within the university culture is significant, as universities have historically embodied spaces thought to symbolise truth, knowledge, merit, achievement, trustworthiness, objectivity and normality (Fine et al., 2004). These representations bolster the power of the privileged member of this binary and constitute hierarchies that work to exclude, deprive and even silence the marginalised member (Sammel \& Waters, 2014). Integral to this process is the requirement that the marginalised member adopt the privileged member's ideologies, values and indeed their very culture in such a way as to be seen as becoming legitimate. The individual must in some way share 'common narratives' with those associated with privilege so they can interpret and transfer meaning in their own lives. Without this common narrative, those holding opposing belief systems and/or ideologies become excluded or rendered uncomfortable, even alienated (Sammel \& Waters, 2014). The ramifications of privilege go far outside the parameters of the institution, embedding a hopelessness cast as a dark long shadow in the communities who remain outside the boundaries of acceptance. Having experienced such exclusion myself, I know how the resulting feeling of despair can lead to anxiety, depression, substance abuse and, even worse, suicide.

Our people are smashed by it, hurt by it, tortured by it. This is a nation of two peoples. The First Peoples and the Australian peoples and unless First Peoples do as they're told then they are punished by every means imaginable.

(Walmajarri Aboriginal mother, Lena Andrews, cited in Georgatos, 2014) 
Ms Andrews made this statement shortly after losing her 18-year-old daughter, Philinka Powdrill, to suicide. Philinka was not someone without capacity - she was described as a bright, enthusiastic girl and had just graduated from a prestigious Melbourne boarding school.

Our people need 'resilience' to cope with the racism that hurts this nation. We need resilience to deal with how we are looked at, viewed, treated, and not just by governments who are in the end responsible for the lot that is racism, but also we need inexhaustible resilience in our daily ordeals with ordinary people who have soaked up the prejudices of one generation after another. We did not expect to lose Philinka. But we did. We did not expect to bury our child. Our hearts are breaking, and we do not know who to turn to. We do not know what to do.

(Walmajarri Aboriginal mother, Lena Andrews, cited in Georgatos, 2014)

There is no older living epistemology than that of the Australian Aboriginal First Nation culture - and yet in the Australian university context, the collective narrative of Australian First Nation peoples continues to be identified as the most marginalised member within the Western binary.

Critically exploring this absence is for us the starting point towards understanding that these constructions are also interconnected and flow into teaching practice using uneven paths of enquiry, benign supposition and conjecture. Subsequently it expresses a 'symbolic violence' of inclusion through either deliberate or benign exclusion.

(Hart, 2003, p.48)

The binary relationship, though shifting back and forth, will always return a position of power to non-Aboriginal people as they are the most powerful in their own construction. Aboriginal people thus find themselves forever trapped in an ongoing process of colonisation in such a way that colonisation becomes almost the perfect system of invasion and assimilation, unavoidable and unstoppable. That idea that racism is engrained in the fabric of society is not unique to Australia where critical race theory determines that institutional racism is embedded deep within the psyche of the dominant white culture, which is far more influential and damaging than any individual racist. Therefore rather than individuals seen as the real problem, it is the existing power structures based on white privilege and white supremacy, which actively marginalise people of colour, that are a far greater problem. It is a point made clear in a 2015 radio interview with the 44th, and first black, President of the United States, Barack Obama:

What is also true is that the legacy of slavery, Jim Crow, discrimination in almost every institution of our lives - you know, that casts a long shadow. 
And that's still part of our DNA that's passed on. Racism, we are not cured of it. And it's not just a matter of it not being polite to say 'nigger' in public. That's not the measure of whether racism still exists or not. It's not just a matter of overt discrimination. Societies don't overnight completely erase everything that happened $200-300$ years prior.

(Obama, 2015)

Therefore in order to overcome the 'long shadow' cast of racial history as Aboriginal and black scholars, we must first return to a place that my own Kamilaroi people refer to as gamil bida-wii (a time before the beginning) in removing the binary of colonisation. In other words, in keeping with the circular and non-linear interconnected worldview of Aboriginal people we must first go back through time and place, as stated by President Obama above, if we are serious about healing the wounds of the present. This would return us once again to humanity's third space beyond black and white, Aboriginal and non-Aboriginal, that identifies and nurtures difference as an inclusive practice rather than the current interface of boundary construction that divides us. The reason we refuse to sit in this third space, I believe, is that, one, some do not want to take responsibility, and two, there are others on both sides who have become addicted to the fight, rather than wanting any sense of resolution or healing to take place. Their very identity has become informed within this division. Outside of those who keep us apart, if we are to heal our humanity it is important that an intellectual exchange between Aboriginal and non-Aboriginal, black and white scholarship becomes established as a 'partnership of learning' rather than the current binary relationship based upon cultural authority, status, fear and hate. The creative component to identify this intellectual exchange becomes representation of a provisional space with equivalence of both 'black' and 'white' (and many shades in between and beyond), that allows the imagination to move past the present binary relationship - a play of difference that in the creation of time and space provides an incorporation of equity which allows for greater understanding within both the rational and intuitive minds. The narrative voice presented as a reinvestigation of the key philosophies embedded within my family's Kamilaroi Aboriginal First Nation epistemology before the arrival of the 'Whiteman' written as a conscious move away from current Indigenous scholarship and towards a defined project, as a 'learning partnership' in a provisional, hypothetical space based on Aboriginal consciousness that build on our humanity as a shared experience. For me, personally, the Aboriginal component of this 'learning partnership' is linked to my own feelings of Aboriginality which have their foundations firmly established in my Kamilaroi family's epistemology, prior to, during and then having survived a process of colonisation. It is the intellectual property contained within this knowledge base, remembered from prior to colonisation, that I now identify as a 'sacred gift' provide to me by my ancestors. 
It is through this collective memory, retained in my family's ability to speak and write its own traditional Kamilaroi Aboriginal First Nation language, that my Aboriginality is shaped and formed, rather than through a process of colonisation.

(Waters, 2012b, p.156)

In answer, then, to the question raised at the very beginning of this book: what does it mean to be Aboriginal in the 21st century? My Aboriginality today, due to my belief and understanding in autobiographical ethnicity, remains first and foremost an intuitive connection to my traditional Burruguu-ngayi- li or Dreaming, as it did tens of thousands of years ago. It is within this belief system that the foundation of my knowledge base associated with my creative and research practice is inspired, but also in having access to the term Burryguu-ngayi-li I am fully aware of the deeper levels of narrative associated with the multiplicity of my Aboriginal epistemologies prior to colonisation. 'Indigenous' scholars who do not have access to their own language are unfortunately dependent upon interpretation and/or translation in the language of their oppressors - of which there is very little direct translation in meaning between Kamilaroi and English. We also know, as presented and referenced throughout the text, that such interpretation is based on racist theory of bias and supremacy over and above Aboriginal ideology and history.

There is no better reference towards the loss of genetic/cultural memory through language than in the term 'Dreaming' itself. Now this is where we really pull the carpet out from those 'Indigenous' scholars who have formed their Aboriginality within the reference tools provided by hegemonic white institutions. We are told that the Dreaming is timeless, dating back to the creation (David, 2002) and also important to the culture and ideology of Aboriginal people and their worldview.

It is necessary first to understand the relationship of reference of these forms to an ontology that lies outside the paintings before one can engage with the visual itself. The Painters stress not their beauty (or aesthetic value) but their referential and ontological truth, defined as their relationship to the Dreaming.

(Myers, 2002, p.20)

No argument there, and we have entire schools of thought which are based on this very principle. Until you point out the truth ... and that is that the Dreaming is not nearly as old, nor as timeless as you would think. Neither is the term unique to Aboriginal people. The reality is yet even more unsettling when you realise evidence of yet more labelling categorisation based on ethnographic ideology that limits understanding of our history and ways of being. Where even our faith system developed over tens of thousands of years is consigned to a history that once again suits a Western canon of learning 


\section{Gamil bida-wii}

rather than any Aboriginal epistemology or living history. This despite, as stated earlier, this dominant history not even representing a blink in time when compared against our own 65,000 years of cultural connection (Clarkson et al., 2017).

In the late 19th century Francis Gillen, a white stationmaster in Alice Springs who spoke the local Aboriginal Arrernte language, became the first person on record to use the expression 'dream times' as a translation for the complex Arrernte word-concept Ülchurringa ('Alcheringa'), the name of the Arrernte people's system of religious belief (Nicholls, 2014). The anthropologist Baldwin Spencer popularised Gillen's words in his 1896 account of the Horn Expedition, the first primarily scientific expedition to study the natural history of Central Australia. Without academic endorsement by someone of Baldwin Spencer's standing, the term dream times may never have survived. At first acceptance of Gillen's terminology was slow, but over time it evolved into the term 'Dreamtime' or 'Dreaming', until A.P. Elkin's 1938 book The Australian Aborigines: How to Understand Them, where Elkin used 'Dreamtime' together with 'the Dreaming'. So it was in 1938, only some 79 years ago, that the term Dreaming became part of the Australian landscape, as part of ... dare I say it again, ethnographic study forged from anthropology in order to label and categorise Aboriginal consciousness (Nicholls, 2014). William Stanner and other Australian historians and anthropologists then made the term generic from the 1970s onwards (Kilborne, 1987, p.249). Stanner himself noted his confusion on why such a term was used in understanding traditional Aboriginal belief systems, stating, "why the blackfellow thinks of "dreaming" as the nearest equivalent in English is a puzzle' (Swain, 1993, p.21). The reality is that at the time the traditional Aboriginal law keepers who were involved with Stanner even complained to him about use of the term, confirming what Maybury-Lewis would write some 30 years later: 'white people would never understand the Dreaming (1997, p.197) when they told Stanner that the "Whitemen had no Dreaming, him go another way" (Kilborne, 1987, p.249). When you consider that the term Dreaming supposedly encompasses our complete ideology in retaining intellectual property over tens of thousands of years, there is no better example of cultural and historical amnesia enforced through a process of colonisation and intellectual theft than the term itself. The Dreaming not only loses significance in its English translation, but also, rather than timeless, it is in reality less than 80 years old.

Part of the problem is the word dreaming itself. Modern society does not take dreams seriously and tends to contrast them with reality. So when we refer in English to Aboriginal ideas about the Dreaming, our own translation of their word implies that we are dealing with a figment of their imagination, something not real.

(Maybury-Lewis, 1992, p.197) 
Societies that see themselves as rational, legal social systems may not take dreams seriously due to their non-tangible nature, but within such societies outside of the mainstream there are some who still recognise and emphasise the significance of dreams. It astounds me that I appear to be the only Australian Aboriginal scholar that picks up such significance in something that is so simple. But then again I have Romans, chapter 16, verse 19, God and my Aboriginal language on my side. Let me explain ...

Tens of thousands of years before the Dreaming was used by white anthropologists and historians as a term referenced within ethnographic study, my people used the term Burruguu-ngayi-li to define our worldview - it was the Burruguu-ngayi-li which first gave birth to the Burruguu, in a process of creation my people refer to as gamil bida-wii, which put simply means 'before the beginning ...', and it is in this time before the beginning that we have the introduction of a number of Ancestral Beings, called the Maran Dhinabarra, responsible for all creation (Spearim, 2012). This was coincidentally around 14 billion years ago during the time of the 'big bang', which won't mean anything until such time a white person can support this statement, but I assure you having gone through a process of initiation and seen drawings of the scarred trees documented by both Mitchell (1838) and Mathews (1895) as well as more recent carvings recording this process, the statement is true. In the meantime I can only hope there's a scarred tree somewhere that hasn't been cut down to make way for a pastoral lease owned by some white farmer that gives the precise date that this Burruguu can be acknowledged by a white scholar and written in English, otherwise we may never know the true origins of our creation. As stated by my uncle and ceremonial leader, who has now passed nguru buruwi-y gaba binaal-ga (may he rest in peace ...),

It's them old people, them spirits blessing the land ... for sure. Look at them carved trees we had at Tallwood, together with ground carvings, that's part of ritual, ceremony ... you know, acceptance of them old people. As part of the everyday learning, that is the knowledge ... is the idea of a continuation of the one story ... they come from a time before creation, this is who they are, them old people ... they had/have a different level of consciousness ... a deeper understanding of this knowledge ...

(Bell, 2012)

The eldest and greatest of these Maran Dhinabarra within the Kamilaroi Burruguu-ngayi-li is known as Budjaar, and it is through a conversation he had with another Ancestral Being, Wadhaagudjaaylwan, that Winnunga-li or Consciousness first gave birth to the Burruguu as a preamble to the Aboriginal Genesis - 'The time of Creation'. 


\section{Gamil bida-wii}

It's a continuation of the one story, it just got bigger and wider ... that's all $\ldots$ a continuation ... but it comes back to this time before the beginning. It comes back to before creation ...

(Bell, 2012)

This idea, that creation (Genesis) is formed from 'some-thing', as in gamil bida-wii ... a 'time before the beginning', rather than 'God created the world from the void of nothing', is unique to the Aboriginal people of Australia, and as discussed by Pope represents an extremely complex and highly developed conceptual understanding of the world around us:

Practically speaking there is no 'creation from nothing'. There is always something 'before the beginning', just as there is always something 'after the end' ...

(Pope, 2005, p.37)

For me personally, that precise moment of inspiration - who or what is reckoned to be 'breathing into' whom or what, and to what effect - has been played out over a number of different times which, upon reflection, become strategic signposts throughout my life - perhaps at times when the Maran Dhinabarra are with me - which again creates for me a sense of autobiographical ethnicity rather than a feeling of disenfranchisement or alienation ... It is within my Aboriginality as Kamilaroi that I remain connected to a circular, non-linear notion of pedagogy where methodology incorporates pedagogy and pedagogy incorporates epistemology, which before I gained entry into the Indigenous academy I always took for granted as an Aboriginal pedagogy coherent and understood throughout the Aboriginal nations of Australia. In moving away from Indigeneity and back towards my Aboriginality I now understand the true significance of certain events as they happen, which are not always understood until much later in life. I have, for as long as I was introduced to my Aboriginality, wanted to demonstrate successfully what I believed to be this idea of an Aboriginal pedagogy, even though I didn't know at the time what pedagogy was. What I did understand at the time, though, was that there had to be a better way of learning that would allow an intellectual exchange, inclusive of race, culture, class and ideas teaching as a shared relationship between student and teacher based upon a circular 'partnership of learning', rather than a binary relationship based upon authority and status.

\section{Note}

1 The term Indigeneity is another form of classification and labelling that restricts our freedom and expression as Aboriginal people within a Western construct. Indigeneity only become prominent from the 1990s and forms an abstract noun from the term Indigenous which restricts Aboriginality down to legal definition and 
Western terms of reference originating out of the Indigenous units formed throughout universities and places of learning within the Western academy. There is no definition of Indigeneity currently within the Oxford English Dictionary, which defines 'Aboriginality' as 'the quality of being Aboriginal; existence in or possession of a land at the earliest stage of its history.' 


\section{Ngamilma-li-ayla-y \\ (Background to the study ...)}

Once again I find myself returning to the scripture Romans, chapter 16, verse 19: 'I would have you wise unto that which is good, and simple unto that which is evil.' It's a statement that reverberates deeply for me, which is why in the Note from the Author at the beginning of this book I wrote the following passage:

As a Kamilaroi Australian Aboriginal I live in one of the richest Western countries in the world, built on an industry of mining from the lands of my own Aboriginal people, many of whom remain living in third-world poverty.

It really is that simple ... I once wrote an article for The Guardian describing the condition of an aged care facility witnessed at Camel Camp, one of the many Aboriginal communities funded by the Australian government in the Northern Territory. Nothing prepares you for what you witness having driven through the multi-billion-dollar mining lands and million-dollar cattle ranches surrounding where this aged care facility was situated. What you witness can only be described as a disconnection from humanity. It was there I met one of my greatest heroes and inspirations, Kathleen Ngale, who is 85 years old, and is living in conditions I can only describe as hell. Kathleen is one of Australia's most successful contemporary visual artists in the world. Below is an excerpt taken from her biography from Delmore Gallery:

Kathleen Ngale (Kngale) has been acclaimed as one of the most significant and exciting contemporary Aboriginal Artists in Australia, creating memorable and visually dazzling artworks. She has been painting on linen for 27 years. As her work has grown in confidence and power, she has become increasingly recognised by national and international collectors and galleries alike. In 2000, she was exhibited by Stephan Jacob in Paris, followed in 2001 by Songlines Gallery, San Francisco. She has taken part in over twenty exhibitions over the past ten years and is represented in the collections of both The National Gallery of Victoria, Melbourne and The National Gallery of Australia, Canberra. Kathleen 
has been a finalist in the Telstra Art Award and is now recognised by important private collectors around the world.

(Delmore Gallery, 2017)

Kathleen's work is sold at such a price you have to negotiate with the gallery if you are interested in buying her work, but the website shows paintings by her sisters Polly and Angeline being sold for up to $\$ 10,000.00$ for one piece. I actually rang the gallery to ask about the price for Kathleen's work 'Wild Plum' (2010, 10J090, 90cm x 151 cm), and 'Wild Plum' (2009, 09G14, 90cm x $90 \mathrm{~cm}$ ), masquerading as a personal assistant enquiring on behalf of a distinguished Māori statesman who did not want to be named. The person representing the gallery, a Mr Don Holt, explained: 'I had a wonderful relationship with the Aboriginal people, I have spent much time out on the communities and had even been out hunting with them ... we get on very well and I make sure they are well looked after ...' which is not what I observed with my travelling companion Gerry Georgatos who wrote at the time, describing Kathleen's residence:

There was no ventilation, no air-conditioning, no in-house services, no anything, only dank concrete, decrepit and filthy - it is however visited by government 'services' and some food drop offs, pitiful. People lay on the concrete swatting flies, holding together resilient while denied dignity and the respite that their years on this earth should have accumulated. Indeed, sadly, I have seen better 'aged care facilities' in the poorest regions of 'third-world' nations.

(Georgatos, cited in Waters, 2017b)

Family told us that Kathleen had lost five kilos in the last month. She was on a mattress on a concrete floor, her blankets look as if they had never been cleaned. I sat next to her speaking ever so quietly in my own Aboriginal language, watching her melt into extended family's arms with so much love it was devastating. I was angry, confused and most of all in utter disbelief, finding myself wanting to cry. I went outside looking for solace and found myself in a makeshift shanty church, its red earth dust floor swept clean among the madness ... this was neglect, abuse and segregation. It was no different in the other communities we visited. The poverty, together with the alienation and scorn they face from outsiders, whites managing their affairs, living in newly built houses and numerous satellites on their roofs connected to the outside world watching cable television, the internet and air conditioning - surrounded by high fences, some who live literally only 100 yards' walk from the locals living in third-world conditions. These same managers telling us the situation is so complex we can't understand or even worse simply not true as you stand there in disbelief, the segregation is right there before your eyes. As if we were talking to people who are somehow blind or just refuse to see. It is a situation that has led to incarceration, poverty and, 
worse, suicide rates among the highest in the world (Hanssens, 2011). The greatest demonstration of white privilege is that Australia is currently ranked second in the world behind Norway in the annual United Nations Human Development Index, which measures health, economic wellbeing and life expectancy. But if Australia's Aboriginal people were to be ranked separately, we would come in around 100 out of nearly 200 nations (Barker, 2007).

Much has already been written at the interface of Aboriginal and nonAboriginal knowledge production; it is a narrative that demonstrates labelling and the hegemonic boundaries preventing knowledge production as intellectual exchange inclusive between cultures. In addition to acknowledging this binary at the interface we need to go further in questioning the resulting loss to Australia, the world and to academia of having never considered Australian Aboriginal knowledge production beyond the binary of opposition and conflict (Nakata, 2002, p.284). Just what does the oldest living culture in the world have to offer us in the 21 st century? In order to fully appreciate Aboriginal knowledge production we must first break down the binaries of opposition that prevent its proper and full acknowledgement. To do this we must first recognise a parallel Aboriginal framework of knowledge production that has been occurring outside of 'Indigeneity', surviving within the Aboriginal communities outside the confines of the Western academy. Despite the binary there are still some scholars such as Von Liebenstein (2000) who acknowledge this parallel system in stating the importance of Aboriginal knowledges in order to produce new knowledge and practices. Aware of the dominance and perceived superiority of scientific knowledge, Von Liebenstein still takes care to stress the complementarity of these parallel Indigenous knowledge systems.

Indigenous knowledge represents localised and community-based knowledge that has evolved within a micro-environmental context. One may therefore jump to the conclusion that sustainable development cannot be fully understood by the exclusive application of formal scientific concepts and methods. Unless development thinking includes indigenous knowledge and global knowledge, these complexities may never be understood.

(Von Liebenstein, 2000, p.10)

Only in recognition of a parallel Aboriginal consciousness running alongside that of Western knowledge production can we successfully negotiate the binary in the development through this third space that moves back and forth through time and space prior to the traumas of colonisation. It is important that concepts of social mobility, localism and agency, defined as social and cultural capital, be identified between Aboriginal and non-Aboriginal people in fully understanding the ongoing disparity that remains between the two groups. But in order for this to occur, we as Aboriginal people and as members of the 'minority' must become assertive in representing our own voice independent from the hegemonic boundaries that have silenced us in the 
past - after all, it is our inherent knowledge as Aboriginal people that connects us to the parallel system, not our achievements or successes within the Western academy. As members of minority groups or in dealing with social issues, people often have to make decisions whether to speak up or remain silent; whether to share or withhold protest and concerns. It was for this very reason I chose to not write this book as Dr Marcus Waters, PhD recipient, but instead as Woolombi Gawuban Gunigal Gamilaraay Kamilaroi Waters.

I am Kamilaroi with five Aboriginal children. Their mother is a Malawali Kalawali and Pitta Pitta Aboriginal woman. My PhD (Waters, 2012b), though important in my journey, does not define who I am. For the purpose of clarification my $\mathrm{PhD}$ was in humanities and remains important in documenting our Kamilaroi ways of teaching and knowing, but for me also represents a constant battle of deconstruction as I fight to retain what is left of my Aboriginality. By introducing myself as Woolombi Gawuban Gunigal Gamilaraay Kamilaroi Waters I am stating that I am and remain first and foremost Kamilaroi First Nation of the Original Australian Aboriginal People. My cultural and social capital is founded on my Aboriginal knowledge passed on and connected to this parallel system established outside of the Western knowledge systems, institutions and places of learning.

Our Yanguru (Moiety as genetic memory) is ancient and our Yarudhaga (Totem as genealogy) is/remains Kubbaanjhaan connecting me to my Burruguu-ngayi-li (Dreaming) as defined through Gawuban Gunigal; the water ways, dreaming paths and songlines that have determined intellectual trade and commerce across Australia for tens of thousands of years.

(Spearim, 2012; Knox, 2012; Bell, 2012)

In expressing my Aboriginality I write this book to you directly as the reader in first person via autobiographical ethnicity, in not only wanting to reach you but share with you the true essence of my identity and also the obstacles we face in maintaining the oldest living culture in the world (Janke, 2011). In consideration of Leonard and Mercier (2015) in accepting Aboriginal knowledges, as neither a third nor hybrid space, I realise that in introducing autobiographical ethnicity I am going beyond previous Indigenous studies, critical race theory and work on settler colonies in now breaking down what Denis Diderot referred to as the 'fourth wall' (Bell, 2008, p.203) in knowledge production. I consciously break down this fourth wall in accessing the 'privileged third space' of Aboriginal knowledge production in making it accessible to the non-Aboriginal audience. As with Diderot's fourth wall, Aboriginal knowledge production was always there - we just never acknowledged it ... until now. The fourth wall illusion is often associated with naturalist theatre of the mid-19th century, and again in 20th-century theatre with actors speaking directly to and/or acknowledging the audience (Mangan, 2013, p.172). More recently popular culture, and in particular Marvel, has again broken through the imaginary wall, in comics, film and television, 
particularly with the feature film Deadpool released in 2016. As a comic character, not only does Deadpool talk directly to the reader, but he is aware that he is a character who drives the story (Keyes, 2015). Of all the Marvel Universe, Deadpool is the most well-known example of this phenomenon where he has been known to

refer to his own history in issue format, lean on the comic panel borders, and see or touch his thought boxes and word balloons and even ripping through the pages of his own comic.

(Comic Vine, 2016)

In wanting to break down the fourth wall of Aboriginal, Indigenous and nonIndigenous relations previously maintained through hegemonic principles of racism and institutional bias formed within ethnographic writing via Indigenous studies, I return us to the first and most important question I ask in wanting to know what it means to be Aboriginal in the 21st century. Much has changed since I was a teenager growing up in public housing in Aboriginal Australia. As with Deadpool in Marvel, I can only do this writing to you directly, fully aware of myself as the author. The most common vernacular we would use back when I was a teenager introducing ourselves as pan-Aboriginal across Australia was simply 'Blackfella', and for me personally also Murri, as I was living in Queensland which identified my state boundary. As stated previously, our Traditional languages were still evolving and adapting our identity parallel to the boundaries established through colonisation in recognising and giving Aboriginal place names to the settler colonies, their states and boundaries.

As I walk around the university I don't often hear the term 'Blackfella' anymore. That being said, when I am back home on traditional country in our Kamilaroi homelands of northern New South Wales and western Queensland you still hear Blackfella in almost every conversation. It is the same when you go to other Aboriginal communities around the country. This realisation was one of the catalysts that began the investigative journey towards first my $\mathrm{PhD}$ and later this book. In breaking down the fourth wall as part of my interdisciplinary practice, emerging from within the academy, back towards my Aboriginality and establishing my written language to popular culture I was able to discover the guiding principles behind our people allowing the universities and public service change the way we were identifying with ourselves and each other. My journey began in reading Professor Marcia Langton, a prominent Aboriginal academic who states, 'such changing definition (whether official or popular) is a construct of both Indigenous and non-Indigenous peoples that is arrived at through a process of dialogue, imagination, representation and interpretation' (Langton, 1993, p.83). While acclaimed Aboriginal writer and co-chair of the National Congress of Australia's First People (National Congress, 2017), Australia's only national peak body voted from within the Aboriginal communities 
themselves, Jackie Huggins (2003, p.60) 'rejects completely definitions of Aboriginality by non-Aboriginal people'. It's an important distinction and interesting that Professor Langton, who represents the Indigenous academy, argues the need for non-[Indigenous] input into discussions of our identity while Huggins, who aligns more with her Aboriginal community, 'rejects completely' expressions of Aboriginality by non-Aboriginal people. What was driving my interest was that as little as 30 years ago, when I was still a teenager, as discussed ... our language was evolving to include the states and boundaries formed from within the settler colony and we were still being empowered through the use of our own languages in identifying this everchanging world around us. I have personally witnessed during that time how quickly assimilationist policies can become immersed within the mechanisms of identification and labelling - as after tens of thousands of years of selfidentification, ceremony and practice, we suddenly find ourselves struggling to retain our own traditional sense of self and belonging where Indigenous studies continues to struggle against its own definition - inhabiting a 'strange inbetween ambiguous space' (Russell, 2002, p.139). It was only in turning away from Indigenous studies and looking towards becoming more interdisciplinary, in sourcing references outside of the academy and within popular culture such as those demonstrated within the Marvel comics universe, that I could begin to find the language I needed to define such a phenomenon.

If we are truly to become inclusive in breaking down the fourth wall between the black and white, Aboriginal and non-Aboriginal interface, we must first connect to the origins of the human condition that determines not only our identity but also our place, and/or belonging in a community and/or society. In retaining our interconnection as interdisciplinary we open every door once closed to us - from traditional Kamilaroi Aboriginal knowledge production, to Marvel comics, to sociology, without questioning our space, our intellectual belonging and our right to speak. In sociology the relationship between self and society, and in particular identity and social change, are fundamental within the discipline. Sociology then becomes vital in understanding - as stated previously - the effects of Aboriginal people having moved out from what was once unique in our cultural space towards a position outside of our own cultural space (Waters, 2016a). The defining concept essential towards understanding exclusion, within sociology, be it of race, class or religion by one group over another, is this notion of 'belonging' and how this concept plays a central role in connecting to not only how the individual is perceived by others, but more importantly how the 'individual sees themselves' (May, 2011). Belonging can be broken down to two sociological accounts determining social change. The first that modernity has led to psychosocial fragmentation, a term that describes the separation or the division of something into pieces or fragments where thought and actions become separate to the other, essentially talking about risk and individualisation. If we are to apply May (2011) to Indigenous studies this would explain the absence of connection between the Indigenous academy and the values 
retained within localised Aboriginal communities that depend on a common culture, identity, shared experience, language and/or worldview. According to May, this would also include: faith systems, income, social mobility, and/or personal agency and/or the lack of contributing to such division - between those who are willing to leave the past behind in order to secure personal agency and mobility and those who remain on the communities. I then belong to a third group who still choose to identify with past values but have left the communities to secure education or employment in trying to represent, or give voice to those who stay within their localised communities ... in other words a voice to the most vulnerable. This third group become metaphorically and emotionally, from my own experience, a frayed single connection between the two that could split at any time. If this third group were to no longer exist, the ramifications towards maintaining the epistemology of our culture through ceremonies tens of thousands of years old would be disastrous - as any connection to our past would become split against the present. This is because the past for those maintaining traditional Aboriginal values is characterised by stable and clearly identifiable social structures that form their identity which are in direct contrast and opposition to those chasing more fluid and contemporary lives (Williams, 1977). Modernity then in itself becomes a form of neo-colonialism absent in the debate of binary associated to Indigenous studies as it 'creates a constant change that unsettles such certainty for those clinging to the past' (Burkitt, 2004, p.220), or in the case of Aboriginal people, an ancient culture within a contemporary world. As a result those non-Aboriginal scholars who employ contemporary Indigenous or critical race theory are missing a key ingredient in understanding why Aboriginal people see assimilation as a form of oppression - somewhat chaotic and threatening. The problem again is in labelling. Indigenous knowledge production has been forced in such a way to fit within the confines of the academy, but in remaining contained within the label of Indigenous studies outside of sociology, and other disciplines including science, we also prevent it from becoming interdisciplinary in its approach. As a vibrant, active pedagogy, authentic Aboriginal knowledge base outside of the academy becomes so complex and multi-layered that meaning can evolve and changed almost daily, which again is why I am having to grab from popular culture, Marvel comics, sociology and my own life experience to explain what for me and those most vulnerable whom I represent is inherent and clearly understood. How sad it is that these Blackfellas living on our communities who have taught me everything I know about my Aboriginality are denied entry into Western academies of learning. Their being deprived access, due to hegemonic barriers, prevents a transfer of ideas and denies non-Aboriginal students exposure to the 'creative hypothesis' that goes beyond conventional time and space applied within Western approaches to learning. Kamilaroi epistemology does not obey the laws of history and science as promoted in the university generally. So in other words we have created a two-edged sword that instead of increasing the viability of Aboriginal knowledges as vital 
within 21st-century study, we have restricted its approach via the label of 'Indigenous studies' and silenced its most valuable voice ... the voice of the community.

Rather than advance humanities and/or science, Indigenous knowledge production has been bookmarked and moved sideways, not being allowed to advance intellectually. This is despite many scholars noting the interdisciplinary approach of Aboriginal knowledge production, including Maybury-Lewis (1992), Von Liebenstein (2000), Nakata (2002), Pope (2005), Hikuroa (2009), Hamacher (2014) and Sammel and Waters (2014), all of whom have noted aspects of quantum mathematics, biodiversity, ecology, sociology and humanities remaining prevalent throughout our traditional teaching practices. The problem is that the complexities of hegemonic binaries that impact on Aboriginal knowledge production being introduced as interdisciplinary supersedes the individual goals of the individual Aboriginal academics and the communities they are meant to represent. This is particularly relevant as urban, educated Indigenous peoples assert their individual identities over traditional practice and ongoing cultural maintenance. There are, of course, other social indicators that contribute to the poor interrelationships among the Indigenous academy and Aboriginal communities, including economies based on structural inequalities and/or geographic regional or residential concentration that divides the urban and remote communities:

the remote communities with the worst problems are those that have been least, and most recently, touched by colonisation, and where people have continued to live closest to a traditional manner and on their traditional lands.

(Sammut, 2017)

The second fundamental according to sociology in understanding the development of an emerging Indigenous middle class disconnected from within their traditional values is 'reflexivity'; what Giddens (1991) and others describe as 'a self-conscious conversation with the self' in the remaking or in the reinventing of one's identity, 'as part of a wider argument about the erosion of tradition and security in late modern western cultures' (Henderson et al., 2012, p.19). Having introduced myself as Kamilaroi first and foremost in questioning the role of the 'un-cultured space', I therefore position myself from outside of the academy where I can then introduce independent narrative and critique. In remaining outside of the academy and as Kamilaroi, it is clear in this independent observation that what unites the two sociological accounts above, 'belonging' and, reflexivity', are in complete opposition to my Aboriginal worldview as their depiction of the past and the present remain separate, and distinctly different. May (2011, p.365) states such statements are 'romanticized interpretations of the past are partly based on the optical illusion created by viewing past societies through social structures, which are easily seen as fixed and stable'. Simmel (1950) and Elias (2001) 
have also pointed out that self and society are mutually connected and therefore cannot be examined separately (May, 2011, p.364). Adam (1996) critiques the dualism of such 'before-and-after analyses of fixed states, established retrospectively' and proposes that tradition has not been replaced by 'reflexivity, disorder, flux and uncertainty', but that these co-exist together. All of which confirms my position as Australian Aboriginal sadly missing in such debate. It might be useful to note that Giddens (1991), in talking about reflexivity, is talking about a challenge to grand socio-cultural narratives of the past that placed white, 'modern' civilisations at the top of the evolutionary chain. This was in comparison to earlier sociologists, notably Durkheim (1912), who actually used Aboriginal cultures in Australia as a means of demonstrating a natural order of advancement in human societies, citing Aboriginal Australians as among the most primitive and less advanced.

As a theorist, Emile Durkheim is perhaps unique amongst recent writers in the extent of his influence upon both sociologists and anthropologists which bears the impress of Durkheim's influence - either as a result of direct study of his works, or indirectly via the teachings of RadcliffeBrown. In his comparative sociology, he never hesitated to utilize material from primitive society because such material shed light upon human institutions in their simpler forms.

(Worsley, 1956, p.47)

So not only are we denied access to participate within the debate, but outside of our labelling as 'Indigenous' we are dismissed as having nothing to offer anyway in regard to such intellectual development. And yet in recent times the academy is starting to incorporate such concepts of interconnection in their own teaching practice defined within life-long learning (Bolhuis, 2003), and interdisciplinary practice is emerging as essential in making scholarship both competitive and innovative (Spelt et al., 2009) - ideas which we as Aboriginal people have been cultivating for tens of thousands of years ...

When my father was first taught the story of creation he was a young man, I mean 8 years old. That was the beginning of his initiation, see, and then he was taught that same story again at 12 . Then again at 18 and again at 30 , that same story ... it's a circular thing, in gaining knowledge. Each level of that same story take on new meaning, interpretation as you get older, there [are also physical] things you gotta do to, get painted up, sleep deprivation fasting and dance ... when you young fella they paint you and then [you] paint up your nephews when you get older, that change [also] to when, that day you get to tell the yarn, you become teacher student and all that business ... life was your teaching and learning this was proper 'black fella'.

(Spearim, 2012) 
As Kamilaroi I am in agreement with Adam (1996, p.135), who critiques the dualism of such 'before-and-after analyses' stating their 'mutual implication' should be the focus of social theory, but as an Indigenous academic I am moved sideways still arguing for inclusion against institutionalised racism. Thompson (1996) also argues that such sociological theory is based on the misconception that traditions are fixed and pre-given, when in fact they are always open to change and flexible - bearing in mind that shifts in contemporary sociological theory would state that Thompson's view of sociology would today be argued by some as somewhat antiquated and impoverished. There is no way Aboriginal people could have lived for tens of thousands of years without adaption and evolution; we were never static and stationary. Recognition of Aboriginal knowledge production running parallel demonstrates that traditions have not disappeared, but rather remain important features of contemporary societies 'though their nature and role may have shifted' (Thompson, 1996, p.94). Simmel (1950) and Elias (2001) both propose that self and society should not be understood independently of each other and that sociologists should be focusing on the relationship connecting them rather than the divisions that separate them.

Despite the idea that reflexivity creates more freedom of choice and fewer ties to the past, research suggests that the Western world is running in the exact opposite direction - with less social mobility today than a generation ago (Schoon et al., 2001; Blanden et al., 2005). What we are witnessing in race relations is that the old forms of inequality are being formed in new ways. Amanda Taub (2016) writing in The New York Times claims white anxiety fuelled 2016's political turmoil in the West, referencing Britain's exit from the European Union, Donald Trump's Republican presidential ascension, and the rise of right-wing nationalism in Norway, Hungary, Austria, Germany and Greece. Michael Ignatieff, a former Liberal Party leader in Canada, has said that in the West, 'what defined the political community' for many years 'was the unstated premise that it was white' (Waters, 2017a).

Again we can't ignore that what is happening in Australia is occurring across the world. The lack of meaningful contribution from not only people of colour but also other minority groups within our major institutions across the West is contributing to the hate displayed against Muslims, refugees and ethnic minorities across the globe. We are witnessing a rise of old racist cries from the past, 'I want my country back', 'we are full', 'Australia for Australians', and, of course, Donald Trump's catchphrase which carried a presidential campaign all the way to the White House, 'let's make America great again'. Lecturer and author Robin DiAngelo (cited in Armstrong \& McMahon, 2006, p.213) calls this movement 'white fragility', the stress white people feel in trying to understand they are not special and are just another race like any other. White fragility leads to feelings of insecurity, defensiveness, even threat. It creates a backlash against those perceived as the 'other'. Beverley Skeggs (2004) also draws attention to how it is only the white middle classes who are assumed to 'have' a self that can be utilised as a collective social and cultural 
capital in creating agency. It is for this very reason that we see Indigenous people willing to give up the values associated with their oppression in joining this privileged class. As Lisa Adkins (2002) explains, it is generally white middle-class men who are rewarded for displaying forms of reflexivity rather than those less privileged. Therefore what Giddens and May describe as 'reflexivity' only has value according to those who have it, as opposed to others who can reflect upon their localism and/or lack of social capital but are not able to find the personal agency or social mobility to change it.

It is for the very reasons stated above that I find myself continually returning to the safe haven of this intuitive third space where I carry my narrative as an interplay between the sensibilities of narrator-character and audience - in suggesting an alternative, non-essentialising, contemporary relationship to history and place. And again in breaking down the fourth wall I must be honest in acknowledging non-Indigenous authors of the past and present who have influenced the formation of interdisciplinary Aboriginal subjectivities that have helped shape my worldview as Kamilaori. It may seem surprising that 'white' inputs into my own identity 'debate', while often traumatic, have also helped me to focus positively, even while 'question[ing] the basis of traditional systems of "Western" knowledge' (Anderson, 2003, p.21). You see, as an Aboriginal child growing up, not only Animal Farm, but many literary classics such as Winnie the Pooh, Dr Seuss, Gulliver's Travels, Watership Down, Tolkien's Lord of the Rings series, and C.S. Lewis's The Lion, the Witch and the Wardrobe all had a profound effect on my worldview and increased my personal agency and social mobility as a child. Would I have had access to these same cultural products if I had been reared by my Aboriginal mother ...? Probably not, but it doesn't justify my being taken from her as a child. Another was the classical music of 'Peter and the Wolf', which I was forced to listen to with other white cousins in my auntie's study over many weekends. It's because of these experiences I cannot completely dismiss white culture as evil, as there is much to suggest it has the capacity to be quite beautiful and inspiring, but as with my being taken from my mother, this does not dismiss the sins of the past nor the exclusion of others today.

As I got older, other white authors would contribute significantly to my own understanding of Aboriginality, first as an adolescent and then later as an academic (Hemingway, 1925, cited in Geismar, 1962; Orwell, 1945; Maybury-Lewis, 1992; Pope, 2005). This has allowed me to not only move forward in theory but also in practice as key theories of place and belonging, identity and community became aligned in an equal partnership and shared vision of how this third space would look once the fourth wall between black and white, Aboriginal and non-Aboriginal was for me broken down. I just hope that we as Aboriginal scholars can get our act together in time so we have something to offer the world once it eventually comes down for us all ... it is, after all, just a matter of time. In the meantime, we as Aboriginal scholars are still arguing among ourselves about what it means to be black, Aboriginal, or Indigenous. 
In 2006 Yin Paradies conducted an extensive review of literature to establish how Australian Aboriginality has been defined by and within the academy, which I again referenced extensively throughout my $\mathrm{PhD}$ (Waters, 2012b, pp.126-128). He referenced an analysis of 'over 700 pieces of legislation' undertaken by McCorquodale (1997), which 'found 67 different definitions of the term "Indigenous" (Paradies, 2006, p.355). Referencing the work of Aboriginal scholars (Taylor, 2001; Huggins, 2003), Paradies noted the emergence of debate whereby Indigenous scholars sought to establish the true meaning of our Indigeneity (I really do not like that word ...) as contemporary Australians as opposed to our Aboriginality. Philip Morrissey, the academic coordinator of the Faculty of Arts Australian Indigenous Studies Program at the University of Melbourne, had earlier stated that Aboriginal Australians who have continued to maintain a more traditional sense of ceremony and lifestyle are at risk of falling victim to 'stereotyped romantic visions of identity' (Morrissey, 2003, p.191). The move away from association of Aboriginality within a traditional Aboriginal worldview is further demonstrated in the works of contemporary Aboriginal Artist Vernon Ah Kee and even Paradies himself:

We're Aboriginal and they're traditional Aboriginal and are a white construct ... Now what happens in the deserts and remote communities is that people create art and they try to live their lives in a way that correlates to this romanticised idea, and it's a white construction. That's why I say that the only authentic Aboriginal people in this country are the urban Aboriginal people.

(Ah Kee, 2006, p.3)

I do not speak an Aboriginal language, I do not have a connection with my ancestral lands or a unique spirituality inherited through my Indigeneity. I have little contact with my extended family, and the majority of my friends are non-Indigenous.

(Paradies, 2006, p.358)

The problem here is that the departure from traditional lifestyle and philosophy becomes an ironic form of authenticity that is born directly from the experience of colonisation straight out of the academy. This departure is not a solution to the initial problem associated with our lack of power within a binary position fraught with hierarchical relations. Ah Kee and Paradies are simply reorganising their position - they are not dismantling, or disengaging from, colonisation and as such the binary remains constant. Also, it is necessary to demonstrate how, as stated by sociologists, the two traditions, as difference, whether black and white, colonised or the coloniser, the oppressed or the oppressor, are always already interwoven, related but without a binary negative power relationship (Adam, 1996; Thompson, 1996; Elias, 2001; May, 
2011). The binary of opposition is so stemmed in institutionalised ideology that in order to break down the fourth wall, autobiographical ethnicity is born out of a need to go beyond dissertation, and instead become also a creative work and drawing also upon popular culture as an experiment of creativity and thought - an imagined reality (ontology) that enables the current binary relationship between black and white to be broken down ... where difference is identified and respected as equalising rather than hierarchising.

Look, if we can return to simplicity and wisdom, if only momentarily ... we, as Aboriginal Australians, remain the oldest living culture and collective human consciousness in the modern world, with Australian human occupation occurring anywhere between 60,000 and 110,000 years ago (Flood, 2001, p.86; Clarkson et al., 2017, p.309). I am concerned to assert the importance of this against the position taken, for example, by Ah Kee, and Paradies. It was during the pre-history to colonisation that our authenticity as a people gained the foundation to survive beyond the binary; despite all that has been thrown at us we are still here, still practising our culture, still speaking our languages, and it remains at the core in understanding our Aboriginal identity. What is at stake with the position of urban construction taken, as a form of ironic authenticity by contemporary Indigeneity, is that as a strategy, it sacrifices too much, puts at risk our own pre-history and unique Aboriginal identity. It creates only a seeming escape from the non-Aboriginal-created binary. It is a negative form of Aboriginal deconstruction. Furthermore, the issue of whether non-Indigenous representations of Indigeneity are 'good' or 'bad' means the very construction of this argument is again based on, and remains dependent upon, non-Aboriginal representation of our Indigeneity rather than our authentic Aboriginality. We must remember that, historically, nonAboriginal approaches in defining and understanding 'Indigenous' epistemologies have focused on the need to survive and control the socialisation, mobility and biological reproduction of those with descent from pre-colonial peoples of Australia (Dodson, 1994). Thus

(t)he experience of a history of description, ascription, prescription and oppression would provide more than sufficient reason for insisting that definitions of Aboriginality must be generated by Indigenous peoples ourselves. Such history should impel the strategies we use today.

(Dodson, 1994, p.7)

The problem is that in many cases, Indigenous people are choosing the safe response of silence, withholding or contributing to a collective voice that could be valuable to others - both Aboriginal and non-Aboriginal, Indigenous and non-Indigenous, black and white. As Aboriginal scholars we have to be honest in asking ourselves, as does Paradies, how many of us still speak our own language, identify with a particular area of land or First Nation group, and are fortunate to have retained ceremony and initiation? According to the research presented in this book, very few ... so we are facing a crisis in 
identity and survival. Colonisation and human rights go far deeper than just the right to have a job. Cultural genocide is a crime and if you don't speak your own language, identify with a particular area of land or First Nation group, and are fortunate to have retained ceremony and initiation practices maintained over tens of thousands of years until only very recently, this means someone has taken away your right to practise your own culture - and that is a crime within the international community as defined by the Declaration on the Rights of Indigenous Peoples as a permanent forum at the United Nations (UNESCO, 2016).

I understand that for many Indigenous people we feel things are improving. We can afford a big-screen television, nice car and we remain employed. But again, if we are to face reality the majority of our people who are working are either public servants employed by the very government that took our human rights away, and if not directly through government their jobs are dependent on some form of government funding dependent on key performance indicators driven by government, not our communities - so why would we put all this at risk because others are suffering? Better to keep our heads buried in the sand. This means the situation is not going to change for the better anytime soon; in reality, when you look around the world outside of your public service cubical you will see it's actually getting worse. And remember, like an untreated sore that spreads, unrest destabilising the black community today will eventually seep into the white community tomorrow, which is why we are seeing the emergence of white fragility and fear suffocating the Western world. Despite our not having anywhere near the influence of social and cultural capital, or political representation and power of whites, we as people of colour are being seen by many as the greatest threat to civilisation, creating hate and division within the West - as neo-Nazi and white supremacist groups begin to emerge as pestilence, the very vermin of the earth rising from the shadows where they have been hiding, but never having fully left us. Only now in the open hostility they have created do they feel confident in once again marching on our streets. The real opportunities gained as a writer in having broken down the fourth wall is the critical currency established in being so immediate in my writing in being able to write about events as they are happening around me, rather than having to wait ten years to have items published and cited before I can generate an academic work of this nature. One that not only subscribes to the rigorous scholarship required in academic writing but also appeals to an intellectual contemporary populace, a people requiring stimulation and debate regarding the ever-changing world we live in.

As I am literally writing this passage, such tensions have exploded in Charlottesville, Virginia in the United States, where a 32-year-old woman, Heather Heyer, was killed by a 20 -year-old white supremacist, James Alex Fields Jr, who drove his car into anti-racism protestors. The Charlottesville Police Department said in a statement that James Alex Fields Jr ploughed into anti-racism protesters who were confronting white supremacists in the Virginia college town, and dozens more were injured in the violence. The rally 
was organised by right-wing Charlottesville blogger Jason Kessler to protest against the city's decision to remove a statue of Confederate General Robert E. Lee. Mr Kessler had described the event as 'pro-white' and said it was 'about an anti-white climate within the Western world'. Interesting that in the same week Australian Prime Minister Malcolm Turnbull condemned the Yarra City Council in Victoria for their decision to no longer celebrate Australia Day on 26 January for very much the same reasons the Charlottesville City Council chose to remove the statue of Confederate General Robert E. Lee, due to its association with slavery, history, and that as a symbol it remains offensive particularly to African Americans.

Yarra City Councillors deemed the date inappropriate because it marked the beginning of British colonisation and the loss of culture, language, and land for Australia's first peoples, Yarra Mayor Amanda Stone said in a statement.

(Mannix \& Cowie, 2017)

Australian Prime Minister Turnbull doesn't agree, as displayed by his actions the very same week as what was happening in Charlottesville. He obviously believes that white people, their history and recognition should take precedence over and above Aboriginal genocide and remembrance, stating that the actions of the Yarra City Council were 'utterly out of step' with Australian values (Mannix \& Cowie, 2017). The federal government has also stripped Yarra City Council of government funding and of its power to hold citizenship ceremonies. The reality of such opinion only maintains a sense of racial superiority and creates an atmosphere where after being supported for the majority of your life in a world that reinforced white supremacy, you become fearful and reactionary to any resemblance of truth that doesn't support your supremacy.

A lot of white men are marching in Charlottesville, Virginia, this weekend, chanting slogans like 'white lives matter' and 'you will not replace us'. The rally suggests that white men are the real victims of the American political climate, due to plans to tear down Confederate monuments symbols of white supremacy and racism.

(Lopez, 2017b)

The reality, of course, is that white men have dominated America, Australia and the colonised world in every major benchmark regarding quality of life and attainment, from education outcomes to home ownership to employment opportunity, health, income generation and wealth, to public office and any other social indicators one can imagine, therefore such fear cannot be based in reality, but what's been constructed emotionally, US scholar Robin DiAngelo explains: 
White Fragility is a state in which even a minimum amount of racial stress becomes intolerable, triggering a range of defensive moves. These moves include the outward display of emotions such as anger, fear, and guilt, and behaviours such as argumentation, silence, and leaving the stress-inducing situation. These behaviours, in turn, function to reinstate white racial equilibrium.

(DiAngelo, 2011, p.54)

In another demonstration of white fragility at the very highest level, the same week the Australian Prime Minister was defending the right for white Australians to celebrate Aboriginal genocide, US President Trump then came under fire for not only his failure to clearly condemn the white nationalist groups involved in Charlottesville, including those who carried torches and Nazi symbols associated with white supremacy, but in actually defending some of those who participated with his comment, 'there were good people among them'.

It took President Trump's defense of a neo-Nazi rally for many Republicans in Congress to publicly distance themselves from the White House, after months of brushing off his impolitic behaviour and tweets. House Speaker Paul D. Ryan said white supremacist bigotry is 'counter to all this country stands for'. Senate Majority Leader Mitch McConnell said, 'There are no good neo-Nazis', an apparent reference to Trump's claim that there were some 'very fine people' among the torch-carrying white supremacists in Charlottesville, Va., last week.

(Mascaro, 2017)

It didn't take long for white supremacist groups to show their support for President Trump on social media, heaping praise on the President via a number of white supremacist websites including the Daily Stormer; and in particular former Ku Klux Klan Grand Wizard and white nationalist figure David Duke specifically pointing out that Trump had ignored the reporters' questions when asked to condemn and name those white supremacist groups directly.

Trump comments were good. He didn't attack us. He just said the nation should come together. Nothing specific against us ... no condemnation at all. When asked to condemn, he just walked out of the room. Really, really good. God bless him. That's why we voted for Donald Trump. Because he said he's going to take our country back.

(Duke, 2017)

While Donald Trump may have been voted for on the promise 'he's going to take our country back', Malcolm Turnbull is running a country determined to never let it go. Only weeks before a neo-Nazi used their automobile in the 
United States to kill an innocent woman, a jury of the supreme court of Western Australia found that Wayne Martin, a 56-year-old white man, was not only innocent of murder, but not even guilty of manslaughter after running over, with his two-tonne 4WD utility motor vehicle, a 14-year-old Aboriginal boy, Elijah Doughty, whom the man had believed had stolen a $70 \mathrm{cc}$ motorcycle. Instead, the man was sentenced to just three years' jail by way of criminal negligence. The killer, was released early from jail after just serving 19 months for killing an Aboriginal child. Elijah would not yet have finished high school, while the family are given a life sentence as they will never see their grandson, their nephew, their cousin, their brother ... their son ever again. The court's decision to disregard the life of a 14-year-old Aboriginal Australian didn't just happen, just like Heather Heyer's death in Charlottesville; it comes from somewhere. This 'somewhere' captured in the violence and gathering of white supremacist Nazi groups in Charlottesville revealed itself through a number of racist posts on social media within the local mining town of Kalgoorlie-Boulder, where Elijah was killed, the week building up to his death.

Kalgoorlie's has two main Facebook community pages, which had posted the following in reference to 'darkies' and suspicion of crime. 'There is going to be revenge of some sort very soon!' one man wrote. Another wrote: 'How many human bodies would it take to fill the mineshafts around Kalgoorlie? A: We're one theft closer to finding out!' Then this only a week before Elijah was run down and killed: 'Feel free to run the oxygen thieves off the road if you see them.' After Elijah's death hit Facebook, one person even commented: 'Good job you thieving bastard. Don't think you'll be touching another bike anytime soon ahaha. About time someone took it into their own hands hope it happens again.'

(Waters, 2017a, p.24)

As Nazis and white supremacists make a reappearance on the social landscape, many mainstream white media personalities are forced to distance themselves from such sentiments. After President Trump's refusal to condemn such behaviour, late-night American television went into a meltdown, with Jimmy Kimmel, James Corden, Seth Meyers and Stephen Colbert among others who condemned white power hatred and President Trump's inappropriate response (Leight, 2017). Of all those who gave social commentary it was Jimmy Fallon's delivery over the others which struck an emotional chord with me:

Even though this isn't a political show, it's my responsibility to stand up against intolerance and extremism as a human being. What happened over the weekend in Charlottesville, Virginia was just disgusting. I was watching the news just like everyone else and you're seeing, like, Nazi flags and torches, and white supremacists, and I was sick to my stomach. 
My daughters are in the next room playing, and I'm thinking, how can I explain to them that there is so much hatred in this world? They're two years old, and four years old ... they don't know what hate is [...] It's important for everyone, especially white people, in this country, to speak out against this. Ignoring it is just as bad as supporting it. And remember that there are people who have given their lives to make sure this type of hate doesn't spread. They fought and they died on the right side of history. One brave woman in Charlottesville, Heather Heyer, died for standing up for what's right, at the age of 32. I can't look at my beautiful, growing curious daughters and say nothing when this kind of thing is happening. We all need to stand against what is wrong, acknowledge that racism exists, and stand up for what is right, and civil, and kind. And to show the next generation that we haven't forgotten how hard people have fought for human rights. We cannot do this ... we can't go backward ... we can't go backward.

(The Tonight Show Starring Jimmy Fallon, 14 August 2017) 


\section{Guwiinbaa-gi ngamuulah biibabiiba (Moving towards the book ...)}

A people's silence only supports lateral violence, alienation and bullying that helps maintain a culture of fear. This silence becomes acceptance and allows abuse to continue unchallenged until lateral violence can flourish into fullblown physical violence. Much of the silence in Australia is maintained by our own Aboriginal people feeling things have improved, feeling they have overcome the obstacles faced by our grandparents, no longer living on reservations/missions and rations, building new opportunities, new lives, leaving the past behind them. The truth is we are as dependent as ever. The rejection of racial discrimination has, by extension, created a new, broader international community. The United States has had their first black president, London a Muslim mayor and Melbourne in Australia a Chinese lord mayor. But rather than advancement, many whites feel threatened by change and it is here we are seeing the rise of ultra-conservative neoliberal politics protecting the status of whites in industry, education and politics, and with it the resurgence of racism exemplified by Donald Trump as President of the United States. In 2016 Andrew Bolt, a journalist with one of Australia's most popular newspapers, The Herald Sun, known for his ultra-conservative views, published 'How activists use Aborigines to censor debate' within his public blog, stating that the Human Rights Commission, Australia's statutory body responsible for investigating alleged infringements under Australia's antidiscrimination legislation as 'disgraceful', and the Racial Discrimination Act, which governs Australia's obligations under the International Convention on the Elimination of All Forms of Racial Discrimination in promoting equality before the law for all persons, regardless of their race, colour or national or ethnic origin, and make discrimination against people on the basis of their race, colour, descent or national or ethnic origin unlawful (Australian Human Rights Commission, 2017), as 'sinister' (Bolt, 2016). As a non-Aboriginal white person, just pause to consider what you just read, that legislation of equality is 'disgraceful' and laws against discrimination 'sinister', and yes Andrew Bolt is one of Australia's most-read columnists and has his own talk show on Australian television. Bolt made the comments defending the right to publish a racist cartoon that portrayed Aboriginal fathers as neglectful, drunk, and not even knowing the names of their children. ${ }^{1}$ The blog went on 
to add, 'so many journalists are on the side of the censors, attacking the free speech they should be defending to the death' (Bolt, 2016). Make no mistake, such words chosen by a white man of privilege only incite the type of rage we witnessed in Charlottesville and Kalgoorlie resulting in the death of two innocent people. But they who incite the violence will never take responsibility. In such an environment of hostility where our civil rights are increasingly coming under threat, it becomes a matter of our human rights to speak back and represent our true voice. If we don't, Australia, the United States and the rest of the Western world continues to travel backwards rather than forwards, despite pleas from The Tonight Show host Jimmy Fallon and others.

Twenty-five years ago we seemed ready to grow the hell up and reconcile with our complicated and often shameful history and look to a strong future as a united nation. But we decided instead to be cowards - or, more accurately, racists. Closing the Gap isn't just yet another national shame: it's a tangible reminder of just how far our nation has fallen, and how much further we're eventually going to have to climb back up.

(Street, 2017)

I had lunch with family and friends over one Easter weekend not long ago, and the right to protest came up in discussion. I couldn't believe the emotion displayed by people who are black and middle class, who rather than fight or represent those less vulnerable instead feel it is their right to remain silent ... that's right ... their right to stay silent. This was despite all but one of them being employed in identified Indigenous positions or organisations. I have no doubt that for many it is hard to recall the level of oppression that gripped our people 40 years ago when it seemed for many that taking to the streets in protest was the only way to promote civil rights as black people in this country and around the rest of the world. But that was also the problem that civil rights within the United States and across the world, including South Africa, become the first priority over and above our Aboriginal rights here in Australia. The problem was that in being given access to civil rights through access to jobs and education, providing for some, the ability to leave behind the anguish of living under permits on missions ${ }^{2}$ or reserves like our grandparents, we never reclaimed our Aboriginal rights as cultural practice in action. This has meant that historically, the intensity and momentum of our political activism has never been consistent. Upturns in protest activity are followed by downturns in struggle and vice versa. At the moment we seem to be on an upsurge with major demonstrations occurring regularly across the country and a momentum shifting towards discussions concerning celebrating Australia Day on the date Europeans arrived and even talk of a treaty ${ }^{3}$ - but unfortunately only in reaction to the current environment of ultra-conservatism, not the status quo which allowed it to rise to begin with.

The 1960s were the last time we witnessed such a dramatic upsurge in political activism, which had a profound effect not only on Australian society 
but the rest of the world. In Australia the political turbulence created in the wake of the Freedom Rides ${ }^{4}$ and the Tent Embassy ${ }^{5}$ going hand in hand with the Australian Referendum of $1967 .^{6}$ Unfortunately, in making such advancements the exploitative and oppressive foundations on which capitalism had been established now found their way into our Aboriginal communities with devastating effect to our cultural practice. This saw the emergence of a new 'Indigenous' middle class as part of the rise of the New Right under John Howard as Prime Minister throughout the 1990s.

John Howard in Australia, has sought to sweep this consensus aside and to replace it with one based in 'economic rationalist' free-market economics, and a new social contract based on private interest and competitive individualism. Both they and sympathetic commentators have seen it as a point of honour to attack everything that came out of the post-war consensus, including the intelligentsia that administered it. Attacks on Aboriginal land rights, multiculturalism, feminism, environmentalism, state-funded higher education, public broadcasting, Keynesian economics and other 'new class' causes aren't merely a convenient, politically opportunistic staple for this new politics. Those making the attacks seek to shift blame onto the shoulders of their liberal predecessors to explain away growing social inequality as a lingering product of misguided attempts at social reform.

(Davis, 2004, p.188)

Aboriginal political activism has traditionally been an extremely varied political force utilising a considerable number of strategies and campaigns, which ultimately meant getting people out on the streets. In dealing with exAustralian Prime Minister Howard's politics and his ruthless attack on Aboriginal subjectivity, we witnessed the movement divide 'grassroots' and 'conservative' middle-class elements of our community. It was under Howard that we saw the fall of the Aboriginal and Torres Strait Islander Commission (ATSIC), Aboriginal Australia's regional body voted from within the Aboriginal communities. The rising Aboriginal conservative middle class agreed with Howard that ATSIC required greater financial accountability and transparency and this was the argument put forward at the time by the Conservative government in dismantling Aboriginal Australia's one regional collective voice. Not surprisingly it was rhetoric that conflicted greatly with reality, documented evidence and fieldwork data taken at the time, stating quite clearly that 'ATSIC was indeed accountable in advancing the needs of the Aboriginal community. It was clear that Howard's Government only put forward the accountability argument as a means of justifying the dismantling of ATSIC' (Ivanitz, 2000, p.3). Once ATSIC was out of the way, representation as one $\mathrm{mob}^{7}$ on behalf of the many communities we represent made way for individual entrepreneurialism and self-proclaimed leadership rather than elected bodies now gone. Though many of these new Indigenous conservative 
entrepreneurs continue, even today, to argue that the Indigenous movement still pursued the same objectives, albeit though different methods - agreement on the vision of the movement became divisionary between the haves and the have-nots.

This period can simultaneously be identified with a new Indigenous capitalism, over Indigenous electoral power due to ATSIC's collapse, which led to a decline in Indigenous cultural nationalism and the fall of Aboriginal revolutionary activity. It is here that Howard will be remembered nationally just as Ronald Reagan is remembered internationally for his role in dismembering black nationalism and Margaret Thatcher the Irish resistance to British occupation (Davis, 2004, p.188), and in doing so laid the platform for the violence and demonstrations against minorities we are seeing across the Western world today.

During this same period, we now embraced being Indigenous rather than Aboriginal, and in doing so we turned away from the fight against a racist government that symbolised post-colonialist oppression where instead these new Indigenous powerbrokers focused attention towards 'passive welfare', as the greatest threat facing our communities (Pearson, 2000, p.1). The emerging Indigenous middle class driving community development through greater employment and educational outcomes over civil liberties, which defined us as having become the problem as in reciprocity, we were not playing our part given the opportunities afforded a new generation. A new welfare reform approach developed in overcoming Indigenous poverty (Pearson, 2000), as in the late 1990s and early 2000s our new self-proclaimed leaders commonly asserted that reformism was not an effective strategy and that only through a fundamental transformation of welfare dependency in embracing free-market economies could we achieve liberation. The government and mining went from the enemy to the solution (Langton, 2012b). We were no longer political activists and social warriors; we had become welfare dependent bludging off white Australian taxpayers, taking advantage of government funding. With no elected body these new Aboriginal corporate warriors no longer looked to attack government in highlighting past injustices but instead looked towards building partnerships of which those on the ground, still traumatised from their past, removed from their families, many still forced to live on missions and reservations, become the stumbling block. And while many still looked towards constitutional change and political reform, these were now instead about perceived excesses in Indigenous funding and greater accountability for government, with key performance indicators established, that took away from the needs of the communities on the ground. It was all part of $\mathrm{New}$ Right ideologues spreading globally via the ultra-conservative politics across the West, that not racism but the welfare system had held us back. Across the world government policy and institutionalised racism were off the agenda and the only way Indigenous or black people could obtain real self-determination and liberation was to become part of the unrestrained system of free-market capitalism. The evidence, though, was the exact opposite. The United Nations Charter on Indigenous Peoples clearly states: 
that Aboriginal people are the ones 'who acutely feel the costs', as 'the global ascendancy of neo-liberal economics and the entrenchment of corporate power in international and national affairs have deepened inequalities between and within nations and largely undermined efforts toward sustainable development'.

(United Nations, 2009, pp.16-17)

And despite the evidence, the Indigenous movement is no longer autonomous of the underlying social structures, political forces and ideologies of capitalist society that continue to oppress our people. This is no better stated than by leading Indigenous Australian academic Marcia Langton when, in 2012, she published in The Australian, the same paper that published the racist cartoon in 2016, her appraisal of Indigenous entrepreneur Noel Pearson, who drove the idea of reciprocity as part of this new welfare reform (Martin, 2001). Langton described Pearson as a hero to the Indigenous community rather than as a villain, as he was seen by the people still living in third-world communities these middle-class blacks had left behind:

Pearson has also enraged Aboriginal people by taking away from the cant of Aboriginal symbolic politics and arguing a powerful case for including indigenous people in the economic life of Australia. He has never resorted to street demonstrations, worn the Aboriginal flag colours or ranted the Aboriginal slogans invented in the 1960s and 70s.

(Langton, 2012b)

Marcia states that Pearson never having marched on the street or 'ranted the Aboriginal slogans invented in the 1960s and 70s' as a badge of honour to the new Aboriginal conservative right. Then, in lecture five of her now infamous Boyer series, after being exposed for a lack of disclosure supporting mining after having received tens of thousands of dollars in cash from mining giants Rio Tinto, Woodside and Santos, Langton went even further, taking a swipe at the legacy of the great Jamaican Marcus Garvey seen by many as the modern father of Black consciousness.

There is a small and powerful group of Aboriginal people involved in the politics of this domain, and a strident few are advocates of the concept of 'Aboriginal sovereignty'. What does this mean? A separate state? Enactment of indigenous rights? Such questions have never been answered, and the concept remains a slogan, one that points to a vaporous dream of self determination but one that does not require any actual activity in the waking world to materialise it. It is Australia's version of the Marcus Garvey movement of 1950s Jamaica that involved the proto Rastafarians in rituals such as waiting on the wharf for their saviour, Emperor Haillie Selassie of Ethiopia to arrive on a ship and rescue them.

(Langton, 2012b) 
The ignorance of such a statement in defining Garveyism ${ }^{8}$ to one decade (the 1950s) and the one group (Rastafarians) is as embarrassing as it is shameful to anyone who knows anything about black history and the international Aboriginal struggle. At the movement's peak of popularity, followers of Garveyism numbered in the millions, with almost a thousand local divisions in the United States, the Caribbean, Central America, Canada, Africa and around the world, including Australia and New Zealand. The movement established at the turn of the 20th century still has many followers today, over 100 years later. Marcus Garvey was a 'great and honourable man' who 'developed the strongest mass movement of Black People in our history' (Van Deburg, 1997, p.317). And then there is the subject of Indigenous [Aboriginal] sovereignty that Langton dismisses as 'a slogan, a vaporous dream of self determination not requiring any actual activity'. I wonder what Professor Langton thought of New Zealand's Māori King Tuheitia Paki's act of demonstrating his own personal sovereignty when he refused to meet the British royal couple, the Duke and Duchess of Cambridge, during their tour of Aotearoa (New Zealand) in 2014. King Tuheitia's office rejected the offer of a meeting, stating 'that the time allotted for the visit to the Mãori leader's base on the Turangawaewae Marae in the North Island was not long enough for traditional protocols to be observed' (Pearlman, 2014). The Māori King stated that he did not want to be seen as 'some carnival act to be rolled out at the beck and call of government' (BBC News, 2014). Until now, in my writing this book, and in your taking the time to read it, we have together touched on ideas from sociology, history, science, anthropology, popular culture and, of course, Aboriginal knowledges, but in citing Professor Langton above and her complete dismissal of Aboriginal and black culture globally, I come to the essence of my work: that before I can openly express my thoughts and ideas as a black Australian, a Kamilaroi Aboriginal language speaker and ceremonial keeper, I am forced to first attempt a fit, no matter how square holed or round pegged that fit may be, into the linear paradigms associated with popular media, the academy and what has been previously shared in relation to Aboriginal and black people. The simple truth is that previous history, particularly in what's been recorded and acknowledged in regard to black and Aboriginal history within the academy, only serves to suffocate my writing and voice so separate is Western knowledge production from the truth. Before we can say anything we spend a lifetime attempting to break down the fourth wall in smashing to pieces the boxes of labelling and expectation of an institutionalised framework which over the last 500 years has only contributed to open genocide and censoring of the Aboriginal voice. Therefore in having jumped through the hoops associated with my $\mathrm{PhD}$ and as an international scholar, now as a black man I am required to cut the umbilical cord of my connection to the establishment in returning to the womb of my ancestry ... which for me is as symbolic as it is physical in moving between both Australia and New Zealand and across the world, where one question 
remains vital over all the others in my quest: what is it then impeding our change ...?

I am sitting in the middle of a pristine untouched rainforest that belongs to the Maroon people of Jamaica. With no taxes, no police and very little crime, the independent community of Asafu Yard in western Jamaica, 'a nation within a nation', is the legal status and autonomy of these Aboriginal Peoples who helped runaway slaves and integrated them into a free sovereign society. Maroon communities faced great odds to survive against both the Spanish and British invaders, and yet continued to obtain food for subsistence living, and to reproduce even increasing their numbers. It was here in 1739 that the Maroons signed a peace treaty with the British to gain sovereignty over the area. Today, the treaty still stands.

(Waters, 2014, p.15)

This was written as part of an article I had published in the National Indigenous Times back in 2014. Visiting the Maroon community changed my life. An elected 'Colonel' governs the people, and when I was there this was Colonel Frank Lumsden, a tall, handsome and athletic man who ran the town as an extended family and community. Unfortunately Colonel Lumsden has since passed away. Their history is amazing. In the New World, as early as 1512, black slaves had escaped from Spanish and Portuguese captors and joined Aboriginal peoples to survive. Sir Francis Drake even enlisted several of these Maroons to help fight during his raids on the Spanish. As early as 1655, runaway slaves together with the Aboriginal people had formed their own communities in inland Jamaica, and by the 18th century, Nanny Town and other villages began to fight for independent recognition, continuing to thrive by growing crops and hunting. Seeking to separate themselves from whites, the Maroons gained in power, and amid increasing hostilities they raided and pillaged plantations and harassed planters in a massive slave revolt denied its true acknowledgment within the pages of Western history.

When the British captured Jamaica in 1655, the Spanish colonists fled, leaving a large number of African slaves. Rather than be re-enslaved by the British, they escaped into the hilly, mountainous regions of the interior of the island, joining those who had previously escaped from the Spanish to live with the Maroons. Their plantation raids resulted in the First Maroon War. The two main Maroon groups in the 18th century were the Leeward and the Windward tribes, one led by an Asante warrior Cudjoe taken as a slave from what today is called Ghana, and the other led by his sister Queen Nanny. Queen Nanny is the only female listed among Jamaica's national heroes. She has been immortalised in songs and legends. She was known for her exceptional leadership skills, especially in guerrilla warfare, which was particularly important in the First Maroon War in the early 18th century. To this day, the Maroons in Jamaica remain autonomous and separate from Jamaican society. Their isolation, which was used to their advantage by their ancestors, has 
today led to their communities being among the most inaccessible on the island. Eleven Maroon settlements remain on lands apportioned to them in the original treaty with the British. These Maroons still maintain their traditional ceremony and practices, immersed within their West African origin and heritage.

I was there attending a conference on Aboriginal peoples, their sovereignty, their customs and practice. The nonsense of Indigeneity labelled within the universities of Australia and throughout the Western world was quickly denounced as absurd by those who attended reclaiming their Aboriginality. It was with passion and strength I listened to Professor Verene Shephard from the University of the West Indies assert her independence from the Western education system in a speech that resonated with me when shared: 'one of the institutions that helped contribute to mental slavery is the education system', the professor commanded in a style reflecting my own ideas on autobiographical ethnicity, not as an academic but as a storyteller enshrined in the history of her people. Dr Marva McClean, a Jamaican-born social justice educator and esteemed scholar on Nanny of the Maroons, confirmed during her presentation: 'I believe that the major reason our students are not successful is that they do not see themselves in the curriculum of their own classrooms. We are made to feel as outsiders - a people whose voices are not relevant.' I realised here, so far away from home, just how important it is that you obtain a cosmopolitan understanding of the world ... that as black and Aboriginal people we need to understand that we are not alone and there are many others, who are confronted with the same despair caused through isolation. I came to the realisation that those who once ran slave ships were the ones now creating this isolation, controlling the organisations and corporations formed as legacy of the entitlement they carry as privileged whites. And rather than be silenced, we as the descendants of slaves and as Aboriginal people across the world have to engage with each other outside of these institutions, not as the minority, but instead a growing voice of enlightenment and truth exposing the damage, not only of our past but its inheritance into the present.

a parallel phenomenon has emerged on the margins: a network of environmental, labour and human-rights activists determined to expose the damage being done behind the slick veneer. Dozens of new organisations and publications have been founded for the sole purpose of 'outing' corporations that are benefitting from repressive government policies around the globe.

(Klein, 2000, p.325)

The conference starts with Traditional Dance and Ceremony, beginning with Colonel Frank Lumsden as he gives thanks to his people and their ancestors with a toast which sees him take a drink and spit it out at the four corners of the stage. He also acknowledges the ancestors of those gathered, 
the many groups of people, black and white, Aboriginal and non-Aboriginal, who have come from around the world. I feel a strong sense of unity and welcome as he gives mention to the 'Ancient people of Aboriginal Australia'. I am there with fellow Warraimay First Nation Australian scholar Dr Vicki Grieves and she too stands as if at attention feeling a pride seldom shared when we are back home in Australia. The moment is broken with the sound of West African drums as the percussion reverberates through the ground and above. The dancing focuses around the children, who range from very young to early adolescent as they take centre stage with the adults including Lumsden himself coming and going, interweaving among the children but never taking their spotlight. I have never witnessed a head of state among the West so available, humble and part of his community. Those on the very periphery then start to move in towards the stage, almost as if catching the rhythm and beat of the West African drums snatched from the air as if batons exchanged where they too join in with the children dancing in perfect time. It is here at this precise moment I understand the full potential of sovereignty and the beauty of my being Aboriginal when allowed to continue the traditions of my people unbroken through time, and the hostility of colonisation. Here on Maroon land in the western Jamaican town of Asafu Yard I now began my journey home. It was this occasion, this celebration and as part of this unity when I first started to conceive this book in its present format. That was now over three years ago - oh, how much my own life has changed.

After the opening ceremony the panel discussions began. The very first presentation was from Dr Erica Neeganagwedgin, representing the Centre for World Indigenous Knowledge and Research, Canada. Dr Neeganagwedgin spoke of her own Taino First Nation Jamaican Aboriginal identity, and her people's resurgence and self-determination. The Taino, like our Palawa Aboriginal brothers and sisters from Tasmania, an island at the bottom of Australia, were once declared as extinct, victim to a holocaust of colonisation. Her lecture was as moving as it was passionate and she spoke to all Aboriginal people when she stated that 'we need to remember the struggle of our ancestors, feel their blood within our dirt, their whispers in the air we breathe and continue the fight to remain ourselves'. Within each panel, as well as continual reference to an ongoing spiritual and physical connection to our ancestors, the other striking similarity was the call to resistance against values of greed, possession and commodity all seen as universal themes of the West. What was also universal and very humbling was the amazing respect gained from each delegate once they realised we were Australian Aboriginal. I have encountered this before when travelling overseas where due to our longevity and connection to culture maintained over tens of thousands of years we are seen as a hope to others acknowledged as the oldest living culture on earth. I also found it very interesting that, as stated earlier, within the gathering Aboriginal was the main term of reference by these brothers and sisters ... even those who came from Canada, where First Nation originates as a term of reference, were reluctant to refer to themselves as anything other than Aboriginal when we were together. 
I was honoured to moderate a session where Dr Anne Bouie, an independent historian and mixed-media artist from the United States, gave a lecture titled: 'A Loud Silence: The Visual Arts as Tools of Resistance and Rebellion.' With so much going on during the conference, with local trading, dance and celebration throughout, it was within this lecture that Dr Bouie captured a single moment in time when everyone became drawn to the stage, nothing else mattered so commanding eloquent and poetic her performance. Dr Bouie started to bring out packages of dirt she had gathered from slave plantations and Jewish extermination camps, smuggled through customs around the world. This was performance art played out by a master architect who held us all emotionally spellbound in her portrayal of graphic memories and fight. I had the pleasure of sitting with Dr Bouie only the day before as we both waded in the fresh running river water that surrounds the Maroon lands, telling her I was a fresh-water Blackfella, where in Australia due to the eco and biodiversity practised as sustainable land management developed over thousands of years prior to white invasion, we became dependent upon our water system. As a form of identification within these law and kinship systems we then refer to ourselves as either fresh-water or salt-water Blackfellas, dependent upon the ecosystem we represent. As an African American Dr Bouie explained to me how lucky I was to be Aboriginal living on country. That no matter the trauma associated with my past, I still lived on country walking on the lands of my people denied to her as African American. She then said to me, 'you know that no matter how bad you think it was, our past, our slavery and oppression ... it was worse than you can imagine'. She explained that in order to survive, 'many things went unsaid in protecting the memories of our dead ...' I knew what she meant. She allowed me to hold her hand and together, a black American woman and a Kamilaroi Aboriginal man, we cried, only for a short time, before breathing in the sovereign black and Aboriginal lands around us.

The more I shared and spoke with these mobs from around the world, the more I realised how much we all need to continue to teach, educate our young ones and remember our old people. The secret to the Maroon success has nothing to do with mining, or commercialisation as we keep being told in Australia - they don't allow either. The reason they function with little to no crime and remain self-sustainable is because not only have they maintained the old collective proverb, 'that it takes an entire community to raise a child', but also, unlike the majority of other Aboriginal nations across the world, they never had their natural resources taken from them. We are told continually that traditional Aboriginal societies cannot function within 21stcentury industry, but this is not due to a lack of sophistication but instead a lack of natural resources. Like any society, to run effectively we need resources, infrastructure, laws and order, and unlike the Jamaican Maroons these have been taken from us in Australia and across the world by governments supporting corporations in the exploitation of Aboriginal lands as a form of neo-colonialism. 
More and more over the past four years, we in the West have been catching glimpses of another kind of global village, where the economic divide is widening and cultural choices narrowing. This is a village where some multinationals, far from leveling the global playing field with jobs and technology for all, are in the process of mining the planet's poorest back country for unimaginable profits.

(Klein, 2000, p.xvii)

Without any staple food or industry, which we had in abundance prior to colonisation, any society would fall. The Maroon people show us that the dream is still there as long as we keep fighting. We have a right to one day have our resources returned to us - to allow our own governance and to reestablish our own community values and teaching. Anything else other than these demands is a compromise. I encourage all those aware of the high-gloss façade of globalisation as neoliberal free trade, to educate yourself in regard to the history of the Maroons as a way of compensating for its absence within Western curricula in schools across the world. And once educated, make the effort to visit and support as many local Aboriginal communities you can rather than continuing to contribute to these industries that wield devastation to the basic human freedoms of people across the world. I returned from Jamaica feeling 'black, loud and proud', having been embraced for my Aboriginality and acknowledged by my international peers as an authority in my field.

I returned home to a storm of racial vilification against Aboriginal actress Miranda Tapsell, whose only crime was to be honest and heartfelt when interviewed about racism in Australia (in Noyes, 2015). Tapsell called for more diversity and inclusiveness on Australia's incredibly whitewashed TV screens after winning a Logie, Australia's equivalent to the Emmy Awards in the United States. This followed an interview on primetime television where she opened up about her childhood and being black growing up in Australia.

'I was called gin bag, nigger, like really full on derogatory stuff', Tapsell said of her childhood experience of racism. 'You don't think that you're worth it. I felt invisible as a teenage girl because I would look at the women that represented a lot of the media and they were tall, they were blond, they were blue eyes, they had fair skin and here I am this short Aboriginal and I thought, "there's not much chance for me".'

(Tapsell, in Noyes, 2015)

When the interviewer then asked her if she identified as Australian, she said no, causing an outburst of racist attacks on social media. 'When I go to Australia Day', she said, 'I don't feel like an Australian that day, because essentially people are telling me that I can't be a part of that' (Noyes, 2015). 
Unfortunately, and wholly unsurprisingly, the reaction of far too many Australians to these words was not to listen, understand, and reflect on them. It was to take offence - because as is made clear time and again in this country [Australia], the feelings of white people are the standard by which all others should be measured.

(Noyes, 2015)

In addition to the attacks on Miranda Tapsell, once again retired footballer Adam Goodes, who in 2015 was victim to an unrelenting orchestrated and conscious act of racial vilification, being booed weekly by tens of thousands of Australians at games and abused on social media after speaking out on institutionalised racism, was being targeted again by the same racism, but this time after being chosen as an ambassador for the department store David Jones (FitzSimons, 2015). Once again the racists came out in force not just against Goodes the footballer but David Jones the department store for selecting an outspoken Aboriginal athlete to represent their brand.

Sure, you could mistake us for bigoted bogans with an ugly racism in us that goes right to the marrow of our bones. You could think that we are the exemplar of Waleed Aly's assertion that Australia is generally tolerant, 'until the minute someone in a minority position acts as though they're not a mere supplicant, then we lose our minds. And we say, "No, no, you've got to get back in your box here".'

(FitzSimons, 2015)

The rest of this chapter then summarises my first month back in Australia that's right, a month in Australia observed by an Aboriginal man returning from overseas, remembering I had just returned from Maroon sovereign lands in Jamaica. After the Miranda Tapsell interview and the Adam Goodes racial abuse, a video showing a group of black African students being asked to leave an Apple Store in Melbourne went viral clearly showing an Apple staff member telling the boys they had to leave the store 'because staff were concerned they were going to shoplift' (Wells, 2015). Apple later apologised, but it doesn't take long when returning from overseas to be reminded that Australia is a nation built on white privilege. For me, it starts before the flight home. Overseas you get used to seeing many cultures gathered at airports no matter where you are flying until you suddenly realise after checking in, and waiting at the gate, that the majority of people with you are white. That's when you realise, oh yeah that's right; I'm going home to Australia. Unless you point it out to them, they, white Australians, don't even notice; that is white privilege in action. Being black in white Australia, everywhere we travel overseas as a family we are asked our ethnicity. Whether in Europe, the United States or elsewhere, people are generally shocked to find out we are Aboriginal Australians. Why? Because they had no idea black people, let alone Indigenous black people, come from Australia. 
In the Australian context, the sense of belonging, home and place enjoyed by the non-Indigenous subject - coloniser/migrant - is based on the dispossession of the original owners of the land and the denial of our rights under international law. It is a sense of belonging derived from ownership as understood within the logic of capital; and mobilises the legend of the pioneer, the battler, in its self-legitimisation.

(Moreton-Robinson, 2003a, p.23)

Just ask Patty Mills, the NBA basketball star who won a championship with the San Antonio Spurs in 2014. Mills, who has a Torres Strait Islander father and an Aboriginal mother, has often spoken about people in the United States not realising that he is Australian due to his being black, assuming he must be African American.

He [Mills] headed to Moraga, California, to play for St. Mary's. It was there that Mills began to notice a pattern. 'I appear African-American', he says, 'so it's not until I start talking that people go, 'Hold on, there's something not right here.' But it's an awesome conversation starter. I open my mouth, they get curious, and I say, 'Got a few minutes? Have a seat.' There's a part of me that's very stereotypically Australian, with the lingo, or for lack of a better way of putting it, the way white Australians would speak. And then, oh, that's not all I am ...

(Wolff, 2015)

Australia is known exclusively as a country of white people. I have spoken with many other Aboriginal Australians who, like myself, my family and Patty Mills, when overseas have had to explain to people, who had no idea that the Aboriginal people of Australia are black. Could you imagine thinking of New Zealand without any idea that Māori people existed, or the United States without black people or Native Americans?

My children are very Aboriginal in their appearance. The look of shock they receive from other Australians when overseas is quickly replaced by a look of what can only be described as an awkward disdain ... it is a look we have become used to and as Aboriginal people living in Australia we see all our lives. People look down as we pass them, or slide across in public seats so we can't sit next to them. Yes, this happens. And we see it, we feel it - and yes it hurts.

(Waters, 2015)

The situation in Australia is so bad that Beyondblue (an organisation established in 2000, as a nationwide counselling and education service in Australia, initially focused on raising awareness of depression and reducing the stigma associated with mental illness and its impact on people's lives), in 2014 started a national campaign that highlights the impact of racial discrimination on the 
social and emotional wellbeing of Aboriginal and Torres Strait Islander people. Beyondblue commissioned TNS Social Research to evaluate the reach and impact of the campaign on the target audience, which is non-Indigenous people aged 25-44 years. Key findings from the report demonstrated many Australians see racism as normal and they also consider discrimination against Aboriginal people as acceptable. Witnessing acts of discrimination was widespread, with more than half of white Australians claiming that they had witnessed acts of discrimination towards Aboriginal Australians. As many as one in five admit they would move if forced to sit next to an Aboriginal Australian, and as witnessed in the Apple Store staff in Melbourne, discrimination is frequent in the retail industry with one in five (21 per cent) admitting they would watch the actions of an Aboriginal Australian over and above a white person in a retail store. One in ten ( 9 per cent) also admitted they would not hire an Aboriginal Australian for a job. Despite obvious poverty and the life gap between Aboriginal and non-Aboriginal Australians, almost half (42 per cent) of Australians believe Aboriginal Australians were given unfair advantages by government in relation to funding and employment and educational opportunities. One third believed Aboriginal Australians should behave more like 'other Australians' and one in five (20 per cent) believe that terms used to describe Aboriginal Australians were derogatory, and racist, but were not that bad as they believed them to be true (Beyondblue, 2014b, pp.1-6).

The real concern is that not only are racist and discriminatory behaviours common, but statistics show that even those who say they do not discriminate against Aboriginal people, also state that such behaviour does not demonstrate racism. Many do not recognise examples of discriminatory behaviour as forms of discrimination, with a staggering almost half (46 per cent) not recognising their wish to move away from an Aboriginal Australian as an act of discrimination and even one in ten (9 per cent) not recognising direct examples of discrimination in the form of verbal abuse as an act of discrimination.

The report found that discrimination against Aboriginal Australians is understood to be an automatic response. One third (31 per cent) believe that telling jokes about Aboriginal Australians is an automatic or unconscious action on the part of the discriminator. One quarter ( 24 per cent) believed that not hiring an Aboriginal Australian would be an automatic or unconscious action on the part of the discriminator. Likelihood to intervene and motivation to reduce discrimination is limited if encountering an act of discrimination, with just under half (43 per cent) saying they would remain silent or not intervene if they witnessed racist behaviour against an Aboriginal Australian (Beyondblue, 2014b, pp.1-6). Returning to Australia from overseas you realise the country just isn't progressive and our people continue to suffer.

The statistics as qualitative data collected from the Beyondblue report confirm that Australia's acceptance of racism is by no means random. In case my observations of my first month home back in Australia returning from 
Jamaica were somehow taken out of context or it just happened to be at a particularly heightened period of exposed hate, exclusion or disdain targeted towards people of colour, I can also cite another month concerning very similar observations at another time having returned to Australia from overseas. As I get older I am finding that I am spending more and more time in Aotearoa (New Zealand) due to the feeling of claustrophobia caused by racism when living in Australia. That when in Australia I am feeling a sense of anxiety, stemming from exposure to racism creating mental health issues for me on almost a daily basis as demonstrated in the Beyondblue (2014a) report, is very debilitating. Don't forget that Aboriginal Australian people have among the highest suicide rates in the world (Georgatos, 2013; Robinson \& Burrell, 2014; Hanssens, 2011). Symptomatic of Australia's problems in dealing with Aboriginal people and suicide, upon my return I read an article in The Conversation, an independent, not-for-profit media outlet (website) that uses content from the academic and research community, where the authors were arguing over whether or not Aboriginal suicide rates are in fact the highest in the world. Rather than cite problems embedded deep within the Australian consciousness, the article was written as if somehow questioning those working in the field were punching the air, striving to make the Guinness Book of Records in making such a claim ... (Ranmuthugala \& Stoneham, 2015). The authors and publishers should have been ashamed ... I used to write for The Conversation. I never wrote another article after reading this, and after some heated discussion with editors, all my previous articles were pulled down from their website, despite at one time being one of their mostread contributors on Aboriginal issues within that medium. Further example that censorship is alive and well from a white majority conflated due to economic, political and social issues based on challenges towards their national and racial identity.

In fact, academic research suggests that other economic and social transformations unfolding at the same time have led many people to anchor themselves more fully in their whiteness - even as whiteness itself has lost currency.

(Taub, 2016)

Outside of such articles written as a form of white fragility, Aboriginal suicide rates are demonstration quite simply that for many Aboriginal people Australia is not the ideal place to live, in fact not worth living at all. So having returned home after 12 months away and being back less than a month after reading an article completely missing the point on suicide, I was then confronted with a number of other major publications arguing whether or not 'blackface' is an acceptable practice. I'm not joking. Blackface originated in the 1820s during minstrel shows where white men would portray plantation slaves and other blacks as caricatures used in mocking black culture. The practice played a pivotal role in maintaining racist ideology 
highlighting the most degrading and ugly stereotypes about black people to white audiences, to make them not only laugh but feel superior. The term coon originated from blackface, where white performers would dress up, paint their face black, and exaggerate their features by bulging their eyes and painting their lips red. The town of Ballarat, local newspaper, The Courier, even put up an online national poll posing the public question of whether 'you' think dressing in blackface is a racist act. Being Australia, a staggering 78 per cent said no it wasn't racist but rather it was 'all just good fun', while only 38 per cent agreed it was racist and 3 per cent remained unsure (Watson, 2016).

The articles and survey originated from social media, after two white Australians went viral on social media after attending an 'Aussie Icon' themed dress-up party going head-to-toe in blackface, dressed in what was meant to represent Aboriginal loincloths with imitation traditional ceremonial markings on their bodies. Social media posts by those who attended the party labelled both men 'legends' and stated they both had the 'best costume' of the night (Tyeson, 2016). The frightening thing is that it was not the reaction to those who called it out as blatant racism that caused the images to go viral; it was instead the torrent of abuse from bloggers responding to the criticism, defending the right to use blackface, that caused the images to go viral. There was an explosion of similar images from around Australia posted by those in support also dressing up in blackface, posting photos and saying it was a joke not to be taken so seriously. Phrases hastily hashtagged into the bottom of a number of the posts included 'back yous in', 'harmless', 'we will black with you', 'lightin [sic] up', 'bit of humour hurt no one', 'we live with a darky', and 'cheer up' (Tyeson, 2016). Aboriginal musicians Briggs and Thelma Plum both suffered in particular, with them both receiving a serious backlash via a wave of torrid and abusive racism after calling out the two men on social media. Comments targeted towards the two Aboriginal performers included being called a 'petrol sniffer' and claims their criticism constituted 'reverse racism'. The hate directed towards Plum was extreme, with one blogger calling the singer a 'filthy half breed' and asking, 'Why don't you kill yourself?' Rapper and white Australian Chance Waters supported Plum on social media asking why he's never been threatened to such a degree for posting inflammatory opinions (Moskovitch, 2016).

I post inflammatory shit people disagree with constantly and I don't get an inbox full of messages calling me a slut or a half breed or telling me to kill myself; what do you think the difference is between the two of us? I have never once been threatened with rape or physical violence for calling people out, but people are willing to deny there's a systemic issue in play.

(Moskovitch, 2016) 
Social media website PEDESTRIAN.TV also supported the two Aboriginal performers against a wave of hostility, with journalist Cam Tyeson blogging:

Here's a hot take for you: This is not something you get to have a fucking opinion on. If people who have experienced systemic racism for their entire lives are saying that something is racist, then it's racist. That is literally the end of the discussion.

(Tyeson, 2016)

Then, just when you think such racist ignorance couldn't get any worse, a white woman misconstrued the support in Australia for blackface as acceptance, wearing blackface with a banner supporting Serena Williams at the 2016 Australian Open tennis tournament during Williams's semi-final clash with Polish star Agnieszka Radwanska. With no idea that what she was doing was wrong, the woman was slammed as 'disgraceful' on social media, with many Americans tweeting it proved Australia is a 'racist' country. American journalist Russell Brown tweeted 'There's a Serena Williams fan in the crowd ... wearing blackface'. 'Not at all surprised', one person replied. Another stated, 'Um, in a stadium full of Aussies, no one was like "WTF don't do that".' Other than being reported overseas and again going viral on social media, the woman, remembering she did this as Briggs, Thelma Plum and other Aboriginal celebrities were being subjected to racist violent rants on social media, received little to no mention within the mainstream Australian media for wearing blackface (Quinn, 2016). In fact, the Australian mainstream media stayed very quiet on the subject of blackface despite the abuse suffered by Aboriginal celebrities, until Liz Cambage, a black Australian and star of the National Australian Women's Basketball team outed a fellow team member, Alice Kunek, for wearing 'blackface' on social media. But then, rather than Kunek rightly being named and shamed, Cambage was instantly condemned and attacked, not only on social media but throughout mainstream Australian media, on television, radio and in print, for her stance against racism, and instead the Australian mainstream media and entertainment personalities defended Kunek for her right to use blackface ... (Watson, 2016).

Still shaking my head, having just returned from overseas, understanding fully the sense of despair and depression many of my people feel, Australia's most popular conservative radio breakfast announcer, Alan Jones, then stated on his show nationally that the country needed another 'Stolen Generation' to fix the 'Aboriginal problem'... (Collins, 2016). Alan Jones was a speechwriter for ex-Prime Minister Malcolm Fraser and remains a regular MC for many Liberal Party and business functions, and lists some of the most influential power brokers in Australia among his closest friends. He has even received a Queen's Birthday Medal as an Officer for Australia. His comment sparked national debate (yes, debate rather than condemnation) with The Australian true to form, once again defending the statement ... 
There are a whole heap of kids going before the courts now, or their families' mums going before the courts, and dads who are on top of the world with drugs or alcohol and suddenly they go back into an environment where children are brought up in those circumstances. Those children for their own benefit should be taken away.

(Richardson, 2016)

To round off my first month back home in Australia, an Aboriginal Member of Parliament was also reported for 'disorderly conduct' for speaking our own Aboriginal language in Parliament ... (Davidson, 2016). And then in attendance at my first all-of-staff meeting back at the university, a senior staff member made a number of ongoing references to the song 'Kumbaya' (Come By Here), which, like the instances of blackface, were meant to be in good humour. After much restructuring and resulting disharmony between senior management and staff the comment was used in what could only be described as a disparaging or sarcastic sense in attempting to engage in creating a need for unity and harmony within the group, as in, perhaps we should all sit in a circle and sing Kumbaya. The song originated as a significant spiritual slave and black Christian psalm.

Far from compromise, 'Come By Here' in its original hands appealed for divine intervention on behalf of the oppressed. The people who were 'crying, my Lord' were blacks suffering under the Jim Crow regime of lynch mobs and sharecropping.

(Originalpeople, 2013)

Every example provided throughout this chapter highlights just how far removed Australia is from the multicultural country it prides itself on being, and how such ignorance materialises as mental health problems, depression and anxiety for Aboriginal Australians. Remember that what you just read, what I shared, was simply my first month returning to Australia. What followed was more Aboriginal people dying while in police custody, revelations that Aboriginal children as young as ten years old were being systematically abused and tortured in youth detention centres, and a spate of young people, again as young as eight years old, committing suicide. My people are literally dying due to the atmosphere of racism causing isolation and despair in a country seen to be one of the luckiest places in the world to live. The reality is that Australian culture is built on a foundation of white superiority and racism so embedded within its national consciousness that they are oblivious. Its people continue to bury their heads in the sand, not only to past atrocities committed against Aboriginal people, but also contemporary behaviour within its mainstream media and at the very highest level of politics clearly demonstrating racism still exists and remains firmly rooted within its cultural landscape ... And please consider that what I shared in this chapter was one month, one month ... just imagine a lifetime shared over generations as 
witness to the extremities of white privilege in action, where the very question of self-reflection, consequences and inappropriate behaviour causing death and misery to others remain non-existent in a country still celebrating the day white people arrived as the catalyst to the genocide and trauma we are witnessing today ... celebrating without remorse. Australian society.

\section{Notes}

1 Bill Leak, a satire cartoonist with The Australian, Australia's largest national newspaper, published a political cartoon in 2016 on Aboriginal and Torres Strait Islander Children's Day, a day celebrating Aboriginal values of family, depicting Aboriginal people as not knowing about their children and not having any role in raising their children. In a shameful display of racial stereotyping and profiling an Aboriginal man was portrayed with a beer can and not remembering his son's name, which divided the Australian community and came under attack by human rights groups. Despite the complaints, the editor of The Australian defended the decision to publish what he called a 'confronting cartoon'. The cartoonist Leak himself said in his defence 'his critics were like toddlers who were suffering from 'Chronic Truth Aversion Disorder' when all he was doing was trying to tell the uncomfortable truth. The New South Wales Aboriginal Land Council filed a complaint with the Australian Press Council and the Human Rights Commission in a statement saying the cartoon stereotypes Indigenous Australians, which came under fire and sent mainstream Australian media into a frenzy defending the right to publish the cartoon as 'free speech'.

2 The Australian government generally controlled reserves, missions and stations, although churches did administer some of them. Government 'protectors', who controlled all aspects of the lives of Aboriginal people, oversaw their treatment of Aboriginal people, and many children were taken from families and forced to live in dormitories where they were beaten and abused. Many were also forced out as indentured labour for Australian pastoralists, and to white families to work as slave labour. The government protectors and the missionaries had no respect for Aboriginal life or their faith/belief systems. After surviving diseases, frontier wars, invasion, racial abuse and dispossession, Aboriginal people were forced onto reserves and missions where they lost the freedom to practise their traditional way of life. There are still Aboriginal people living on government-controlled missions today.

3 Almost 200 years after white European invasion, Australia still remains the only Commonwealth country to have never signed a treaty with its Aboriginal people. While treaties were established early on in other British dominions such as New Zealand, Canada and in the United States, the situation in Australia was notoriously different, marked by acts of genocide and slavery. As long ago as 1832 the absence of a treaty was cited by the governor of then Van Diemen's Land, George Arthur, as a crucial and aggravating factor in 'relations with the first inhabitants of the island', the scene of some of the worst treatment inflicted on Aboriginal people of all the British settler colonies. Governor Arthur reflected ruefully on his colonial administration's chaotic - and bloody - relationship with the island's Aboriginal population, saying it was 'a fatal error' that a treaty had not been entered into with the Aboriginal people of what's now the Australian state of Tasmania, after white settlement had commenced some 30 years earlier.

4 In February 1965 a group of University of Sydney students called the Student Action for Aborigines (SAFA) organised a bus tour of western and coastal New South Wales towns. Their purpose was to draw public attention to the poor state of Aboriginal health, education and housing. They wanted to build awareness of the 
socially discriminatory barriers which existed between Aboriginal and white residents. They also wished to encourage Aboriginal people to resist discrimination.

5 In the 1960s and 1970s, inspired by the Black Power movement in the United States, Aboriginal people were politically very active. In April 1971 the Northern Territory Supreme Court decided against Aboriginal people and in favour of a mining company to have access to Aboriginal land. Aboriginal people travelled to Canberra in protest, asking for title to their land, royalties from the mining operations, a right to consent to or reject further development on their land, and for the land to be returned once mining operations finished. Instead the government applied new 50-year general-purpose leases over such land. Angered by this announcement, Aboriginal people gathered in Sydney and decided that on Australia Day 1972 four representatives would travel to Canberra to protest against this decision. They were Michael Anderson, Billy Craigie, Bert Williams and Tony Coorey. The four erected a beach umbrella surrounded by placards in front of Parliament House proclaiming it an 'Aboriginal Embassy'.

6 In 1967, after ten years of campaigning, a referendum was held to change the Australian Constitution. The referendum campaign effectively focused public attention on the fact that Aboriginal and Torres Strait Islander Australians were second-class citizens with limitations, both legislative and social, on their lives. Two negative references to Aboriginal Australians were removed, giving the Commonwealth the power to legislate for them as a group. Many saw this change as recognition of Aboriginal people as full Australian citizens for the first time since the arrival of Europeans.

7 The word 'mob' is regularly used by Australian Aboriginal people to refer to a group of people, but unlike broader English, it does not mean an indiscriminate crowd, but instead a cohesive group usually associated with extended family, local area or a particular nation or group: i.e. my mob - my people, or my extended family. Mob is also often used to refer to a particular language group - that Kamilaroi mob.

8 Garveyism is an aspect of black nationalism that refers to the economic and political policies of its founder Marcus Garvey. At the movement's peak of popularity, followers numbered in the millions, with almost a thousand local divisions in the United States, the Caribbean, Central America, Canada and Africa. The ideology of Garveyism centres on the unification and empowerment of African-American men, women and children under the banner of their collective African descent, and the repatriation of African slave descendants and profits to the African continent. Garvey put forward his dreams in response to the marginalisation and discrimination of African Americans in the United States and the Caribbean at the time, with the hopes of inspiring black Americans to proactively establish infrastructure, institutions and local economies rather than expecting such from the heavily prejudiced post-reconstruction American government. The movement had a major impact in stimulating and shaping black politics in the Caribbean and in parts of Africa, and across the world including Australia and New Zealand. 


\section{Nguwa ... ngay dhubaanma-li gay (Here ... I'll tell you a story ...)}

Australia is suffering from a form of cultural amnesia where they are willing to sacrifice Australian Aboriginal pedagogy as the oldest living culture in the world to assimilationist policies driven towards participation and access programmes disguised as Aboriginal advancement. Government, together with education, big business and mining via the media, is driving such assimilationist policies through engineering 'moral panics' throughout Australia within Aboriginal communities built on accusations of child abuse, domestic violence and welfare dependency targeted as increasingly multi-generational and problematic within Aboriginal communities. To fully appreciate the cultural impact of these policies, a new theoretical framework needs to be offered that conceptualises the significance of traditional Aboriginal pedagogy, repatriation and language requisition beyond the narrowly defined parameters of 'disparity' used as a catchphrase ensuring that traditional Aboriginal culture is seen as redundant, with nothing to offer, something to be left behind in order for Aboriginal people to take their rightful place in Australian society. Such strategy, of course, washes its hands of any responsibility for settler colonies to accept the consequences of their ongoing oppression of Aboriginal people. As the oldest living culture in the world, Australian Aboriginal culture is important simply because of its presentation of surviving and having endured not only the horrors of colonisation but the tens of thousands of years of productivity and continual culture achieved before white European invasion. Aboriginal culture must be seen beyond the product of socioeconomic context, but rather as the result of reflexive engagement with intergenerational teaching and ritual maintenance practised, despite every environmental obstacle faced over tens of thousands of years - and in particular the last 200 years, when every strategy imaginable was employed against it by European invaders in an attempt to wipe it from the face of the earth. And yet we survive, kept in place by individual keepers of ceremony and language retention throughout the many Aboriginal communities of Australia. Put simply, the collective human memory retained over 60,000 years is too vital in understanding our humanity to give up the fight now ... and after 60,000 years at least, we have no intention of giving up our survival, our language, our very way of life. 
Extending beyond white Australians' mere nostalgic patriotic yearning to the time of Australia's colonial past, living in Australia as a person of colour not only are you confronted with racism embedded within the foundation of the nation's history, but it becomes clear that there remains a marked effect on the autobiographical ethnicity of the modern Australian, their personal image, their political outlook, and their attitude towards people of colour. Australia's contemporary place in the world is so well influenced by its longterm attachment to its colonial past that it drives the present. To understand where such dependency forged in white supremacy and privilege comes from it is important to examine the various ways in which Aboriginal people have been theorised in academic studies and media throughout generations of government policies since invasion. While there is a much-documented existing body of work which has yielded rich data on Aboriginal separation and the gap between Aboriginal and non-Aboriginal quality of life, the almost exclusive focus on 'disparity' has resulted in an under-developed understanding of Aboriginal pedagogy, knowledge production and cultural maintenance. Acknowledgement and responsibility taken from the trauma associated with invasion is practically non-existent. Let's be clear - Australia, like every other Western country, was colonised through a forceful aggressive invasion. People were massacred, their land and children taken. Before we were invaded Aboriginal people demonstrated a highly complex multi-layered society built on kinship systems that regulated land use agreements across over 500 separate nations.

I had the pleasure of sharing a panel with Aboriginal historian Bruce Pascoe at Yabun, Australia's largest one-day gathering of Aboriginal people in the tradition of Aboriginal 'Survival Day' gatherings, where rather than celebrate European invasion on Australia Day we rather celebrate our survival. These 'survival gatherings', have occurred throughout the country since the 1930s, and seek to commemorate, bring attention to and celebrate not only our survival but our intention to keep surviving. Yabun is a highly anticipated yearly event that provides a positive social space for audiences to celebrate, share and immerse themselves in the world's oldest surviving culture. I was truly honoured to share the stage with Bruce Pascoe, a Bunurong man, of the Kulin nation. Bruce, as an Aboriginal historian, researcher and author, is one of my childhood heroes. His book Dark Emu (2014) examines not only the history of Aboriginal relationships prior to invasion by white Europeans but also how this history and the time since invasion has been reinvented as white fiction contentious in wiping the pre-history and technology of our people from history. Pascoe methodically and carefully presents growing evidence and research that rather than hunter-gatherers, Aboriginal people grew much of the food they ate, built permanent housing, often lived in settlements surrounded by beautifully landscaped grounds. We also created elaborate aquaculture infrastructure, cultivated and harvested grains and managed the land in a way that prevented the catastrophic annual bush fire season that occurs every year within Australia. 
there is mounting evidence that sustained Aboriginal fire use shaped many Australian landscapes by sharpening vegetation boundaries, maintaining open vegetation, and creating habitat for game species. Such skilled burning reduced the extent and intensity of fires, allowing fire-sensitive plant communities - such as those in the Tasmanian wilderness - to persist in flammable landscapes.

(Bowman, 2016)

The only bush fires we had in Australia prior to invasion were intentional in both clearing land and allowing it to grow. Not just Bruce Pascoe but Bill Gammage also in his book, The Biggest Estate on Earth: How Aborigines Made Australia (2011), suggests that the biodiverse landscapes taken by the British in an act of hostile invasion were already cleared and maintained as a direct result of skilful and sustained fire usage. Intentional fire burning and other forms of land management were practised over tens of thousands of years. The surveyor and explorer Thomas Mitchell's writing during the 1800s appeared divided in admiration for the care maintained of the land by Aboriginal people and by the taking of this same land by the English. Mitchell often wrote in clear description of Aboriginal society and the biodiverse land management he witnessed.

A land so inviting and still without inhabitants! As I stood, the first European intruder on the supreme solitude of these verdant plains, as yet untouched by flocks or herds; I felt conscious of being the harbinger of mighty changes; and that our steps would soon be followed by the men and the animals for which it seemed to have been prepared.

(Mitchell, 1837)

Mitchell is correct in his assessment that these 'verdant plains' had indeed been prepared, not for the European invasion, but instead for sustainable growth and production for generations of Aboriginal people. Bruce Pascoe and Bill Gammage have recorded that the demonstrated skilful use of fire created fine-grained burn patterns, designed to promote food resources and maintain sustainability. Their writing explodes the myth that pre-settlement Australia was an untamed wilderness, instead revealing the complex, countrywide systems of land management used by Aboriginal people across Australia. Early Europeans often commented again and again that the land looked like a park with extensive grassy patches and pathways, open woodlands and abundant wildlife, evoking a country estate in England. Bill Gammage has discovered this was because Aboriginal people managed the land in a far more systematic and scientific fashion than has ever been realised in any historical context. Once Aboriginal people were no longer able to tend their country, it became overgrown and vulnerable to the hugely damaging bush fires we now witness today. 
Black Saturday (VIC), 7-8 Feb 2009 resulted from some of the worst fire conditions ever recorded in Victoria. Record-high temperatures and strong winds after a season of intense drought set the bush alight across the state, causing widespread devastation, 173 fatalities and the destruction of more than 2000 homes.

(Williams, 2011)

What we are now discovering is that Aboriginal people managed a larger area of land under cultivation than modern farmers manage within Australia today. The early white settlers, as well as introducing sheep and cattle, deliberately destroyed these huge areas of grasses, rice, and extensive yam and daisy fields. Much of the evidence demonstrating the extent and the sophistication of biodiversity and cultivation as land management by Aboriginal people is sourced from the diaries of these early invaders. Men such as Thomas Mitchell also included detailed drawings and photos. As part of the invasion, historians, anthropologists and surveyors lied systematically in both their official reports and in what they witnessed. Charles Sturt wrote in his journal in 1847:

The character and spirit of these people is entirely misunderstood and undervalued by the learned in England, and the degraded position in the scale of the human species into which they have been put, has, I feel assured, been in consequence of the little intercourse that had taken place between first navigators and the aborigines...

(Sturt, 1847)

The erasing of Aboriginal history was not the acts of random individuals, it was systematically orchestrated and intentional. In the context of this new tobe-written history, Australia was to be celebrated as the birth of the new nation, pioneered by great white European explorers. British colonisation was legitimated in the complete denial of the pre-history and prior ownership of the original Australians. An essential part of this process was that our ways of life, practice and culture were consigned to the past - but not to history ... rather we became the subject of anthropology, which again rooted in ethnographic studies demonstrates the need to put forward autobiographical ethnicity as a narrative of truth in deconstructing the lies of our written history. Rather than our brilliance being identified, we were only valued as artefacts, remnants of a primitive stone age past. White European history became a modern and deceptive truth in representing a civilised, sophisticated future not only within Australia but throughout the Western world where anthropology categorised Aboriginal people as being caught in the past, labelled as savage (Fabian, 2014). The problem in now trying to deconstruct/decolonise the history of the institution, is the very tools of the institution itself. Where ethnographic writing has been used in the past by many Indigenous writers, no matter how well intended, it still remains tied to ethnocentrism and the 
parameters and restrictions of anthropology - as a direct and influential product used to devalue Aboriginal knowledges and culture. As stated by Trigger (1985, p.34), 'the original differentiation between history and anthropology was product of colonialism and ethnocentrism' and therefore autoethnographic writing rather than freeing our Aboriginal voice only confines us to the silence and racist boundaries of the past, as the institution where it originated was used as a major weapon in silencing our voices around the world. This 'denial of coevalness' (Fabian, 2014, p.31) became the construction of Australian Aboriginal culture and characterised anthropological study well into the 20th century, where we were either relegated into pre-history ... or instead suspended in a 'timeless vacuum' (Beckett, 1998, p.195). This denial of history also attempted to wipe out any spoken or written memory of the devastation incurred by Aboriginal groups by early settler communities where invasion became non-existent and in doing so created a scholarly division between truth, denial and history (Hodge \& Mishra, 1991).

they mean the history of the white people who have lived in Australia. There is good reason why we should not stretch the term to make it include the story of the dark skinned wandering tribes who hurled boomerangs and ate snakes in their native land for long ages before the arrival of the first intruders from Europe ... [The historian] is concerned with Australia only as the dwelling place of white men and women, settlers from overseas. It is his business to tell us how these white folk found the land, how they settled in it, how they explored it and how they gradually made it the Australia we know today.

(Murdoch, 1917, p.9)

In 1968 W.E.H. Stanner delivered the annual Boyer Lectures for the Australian Broadcasting Commission. Coincidentally, these are the same forum of lectures that an Aboriginal woman, Marcia Langton, would use to denounce the influence of Marcus Garvey and state that black and Aboriginal grassroots activism was dead 44 years later. I guess God really does work in very mysterious ways ... In the second lecture of the series, titled 'The Great Australian Silence', Stanner called out not only the intentional and deceitful neglect of Australia's Aboriginal history, but also those who had orchestrated their complete absence. Stanner argued that our absence as Aboriginal people could not possibly be explained by absent-mindedness, but was instead deliberate and conceited.

a structural matter, a view from a window which has been carefully placed to exclude a whole quadrant of the landscape. What may well have begun as a simple forgetting of other possible views turned under habit and over time into something like a cult of forgetfulness practised on a national scale.

(Stanner, 1969, p.25) 
Leading Australian historian Henry Reynolds was so greatly influenced by Stanner's plea for truth and justice, he committed his life to addressing the great Australian silence. In doing so Reynolds, at times receiving vicious criticism from ultra-conservatives who accused him as well as others for taking on a black armband of history, ${ }^{1}$ and other historians were accused of being biased and negative at the sacrifice of white Australians and their pioneering spirit. This was because they had challenged Australia's white pioneering past with difficult truths, revealed in journals and handwritten accounts and Aboriginal oral histories documenting a brutal invasion over peaceful white settlement, which the ultra-conservatives labelled as a black armband view of history.

'Black armband' history came to define a growing reappraisal of Australia's past, demonstrated through public remembrances like Sorry day. It was a label of derision, a blanket term designed to dismiss critical approaches to Australian history as unnecessarily bleak and overly 'emotional'. This 'black armband' tag was a strategic conservative swipe at histories that revealed Australia's past as racist and violent. Its application served to present critical history as unbalanced, a misrepresentation of our national heritage. Such a view held that, in spite of its historical 'blemishes', to deny Australia its rightful national history was at best reckless, naïve, at worst unAustralian.

(Clark, 2002, p.1)

Henry Reynolds's reply was that the alternative to a black armband was a white blindfold (Wimmer, 2002, p.13), in referring to a history Australia would prefer to forget. In further response, Reynolds stated:

Early 20th century history was self-consciously nationalistic, written to foster patriotism in the present, pride in the past. Racial violence was an embarrassment, best forgotten, especially as the heroes of the pioneer legend - squatters, prospectors, explorers, overlanders - had helped to bloody the billabongs. To create doubts about the means of European occupation was to question the morality of settlement, even the right to the continent. Such questions had no place in works which celebrated steady material progress, the creation of free institutions, and the evolution of a happy, hedonistic life-style.

(Reynolds, 1984, p.4)

Reynolds would also go on to state that in revealing this 'new history' of truth hidden deeply in the denial of Australia's past there were 'important implications for our view of Australia past and present, not just a matter of attaching Aboriginal history to the back-left-hand corner of the old homestead or of even glassing in the back verandah', but instead once acknowledged 'the 
changes will ultimately have to be far more radical - a new floor perhaps, even new foundations' (Attwood, 1996, p.23).

What is less apparent, despite revealing the hidden past as truth, are the factors which have enabled the identified systematic denial and exclusion of history to become a force of change. As with sociology (Burkitt, 2004), historical and archaeological scholarship has been dominated by convention, where the past is relegated to another realm of time separate from the present. As a consequence scientific methods adopted as truth (Fine et al., 2004) deny the possibility for the historian and the archaeologist to show the past as it really was - and therefore drive its influence towards the present, which again dictates the need for autobiographical ethnicity to be introduced as an alternative, independent from what has been perceived as historical truth maintaining white supremacy and privilege as the pillars of Western society. In accepting the interdisciplinary pedagogical responses of Aboriginal epistemologies via storytelling and human experiences we identify a culture that values 'objectivity', as one cannot remain stagnant in having survived over tens of thousands of years. The wish to cut our ties to our past prior to colonisation is not only an act of cultural genocide, through an enforced amnesia of history, identity and culture, but moreover creates acceptance of historical white knowledges that prevent any wish to establish 'truth'. Instead, we as Aboriginal extended families and within our communities as uncles, aunties, fathers, mothers and ceremony leaders talk about our identity as story and knowledge related to traditional ceremony, practice and ongoing cultural maintenance. We should be talking in these same terms in our professional lives. As public servants and academics, politicians and writers, teachers and researchers, we need to draw upon our sense of Aboriginality as something having endured and survived over thousands upon thousands of years, independent from colonisation and/or invasion. Yet currently all this is replaced by the binary of colonisation in wanting to become accepted within the very institutions established to oppress us. The struggle for truth then becomes timeless, tireless and never ending, so in the end we just accept what we are being told by the institution. It is not surprising, then, that we are beginning to lose connection with who and what we are - as this was constructed and orchestrated from within the idea that Aboriginal advancement can only be achieved in closing the gap between ourselves and whiteness. As Aboriginal people we then become lost, devoid of knowing who we are and where we come from. So we must, as Aboriginal peoples, debate among ourselves (and within ourselves) the true meaning first in understanding our unique Australian blackness - and define where we sit within the labels of our Aboriginality and/or our Indigeneity before progressing further; whiteness in that regard is actually inconsequential and nothing more than a distraction. Paradies (2006) reminds us that:

(h)istorically, non-Indigenous approaches to defining and understanding Indigeneity have focused on the need to surveil and control the 
socialization, mobility and biological reproduction of those with some descent from pre-colonial peoples of Australia.

(Paradies, 2006, p.269)

We must heed Mick Dodson's warning now over 20 years ago when he stated in his 1994 Wentworth Lecture:

without our own voices ... Aboriginality will continue to be a creation for and about us, all the more reason to insist we have control over both the form and the content of representations of our Aboriginalities.

(Dodson, 1994, p.19)

Twenty four years later current boundary setting and policing only serves to alienate Aboriginal people (past, present and potentially future) who outside of the universities and government-funded positions have retained traditional knowledges outside of the binary relationship of intellectual resistance and colonisation (O'Regan, 1999). The positivist tradition of the pioneering settlement that denies historical Australian truth as 'black armband' allows conservatives to accuse Aboriginal historical narratives of being evidentially weak or false and thus dismisses legitimate claims of identity, technology, innovation and sustainability. In addition, it enables conservative attacks upon historical truths as a 'rewriting' or 'reinterpretation' of history (Brunton, 1992, pp.13-23). One must then ask ... who benefits today in wanting to maintain a conspiracy denying tens of thousands of years of prior occupation, cultivated biodiverse farming, innovation and civilisation, to instead celebrate the invasion and the devastating effects incurred by the Aboriginal people of Australia through the arrival of white Europeans? The answer is simple ... the descendants and followers of those white Europeans who invaded are the only ones who obviously benefit.

Even today within our communities Aboriginal people are only too well aware of how we systematically burnt grasslands to regenerate soil and stop fires raging out of control. This inherent knowledge passed down from generation to generation is only the very beginning of what was once a highly effective and multi-layered approach to land management. Stories are shared from around Australia in ceremonies that describe how our people worked systematically over tens of thousands of years to make plants and animals abundant, convenient and seasons sustainable. My own experience as Kamilaroi involves many ceremonies that share information on the distribution of plants in mosaics used to lure animals during breeding and hunting cycles recorded on scarred trees and cave paintings centuries before European arrival. The only problem with the white construction of false truth, is that we survived to eventually tell our side of the story after the civil rights movement meant they could no longer keep us silent, living on missions and reservations condemned to a life of indentured labour maintaining their lies. Yes, the only part of the plan that conceived the great white Australian dream, or what 
Stanner referred to as the great Australian silence, is that we survived to tell the truth. Recent revelations of truth as written by Henry Reynolds, Bill Gammage and Bruce Pascoe are nothing more than a recently untold history maintained via kinship ties to land boundaries providing us in-depth knowledge of the country, history and stories we have shared, generation upon generation, for tens of thousands of years. It would only be white privilege, fragility and ignorance that would then be surprised that we kept telling stories, sharing knowledge and documenting the invasion by these same processes after the coming of the white Europeans. Not only the invasion, but also the knowledge, history and the lives of our people and their communities prior to the invasion was also kept. We don't need books published by white people and their institutions to tell us how we consolidated our natural resources, even changing country, sometimes dramatically, with fire or no fire. This is our very living history, not theirs, and our only conflict is in wanting to share it with you, your children and your children's children. You know why? Because it works, it creates sustainability and understanding of the lands where you live. 'No fire', because a conscious decision not to burn also regulates plants and animals. We decided when and what to burn and also when not, how often, and even controlled temperature through burning. We cleared undergrowth, and put grass on good soil, clearings in dense and open forest, and tree or scrub clumps in grasslands.

Through the tireless work of these black armband historians radicalising written history as (un)truth, what is now emerging is acknowledgement of a practice in enough dispersed areas across Australia to demonstrate working treaties and intellectual trade roots across Australia. These practices were maintained within such a variety of individual Aboriginal nations in Australia, or should I say Aboriginal Australia, prior to white European invasion created the single largest managed land estate in the history of humankind (Gammage, 2011; Pascoe, 2014). The simple truth, no matter how well covered up or denied, is that no other culture or continent anywhere in the world comes anywhere near such demonstrated understanding of biodiversity and/ or land management. There are two very important factors at play here: one, that somebody lied; and two, that simple truths that we have accepted without fault have been at the very least misguided and at worst part of an absolute denial practised in Western civilisation as a form of cultural genocide, which not only denies the truth ... but rather than enlighten us has led humanity down a path of eventual societal ruin. That's right - lies and ruin.

Not only were we not meant to be here, but those who had survived definitely were not meant to have access to their language, ceremony and history. In citing my autobiographical ethnicity as truth, I am able to observe independently from outside the West ... rather than just accept that I am part of something I cannot control. I understand and relate that I have an alternative history, reality and future. It's hard to put your finger on it when you are still a child in school, when you are too young to articulate what I am now doing in writing this book, but there is something inside you, inherent as an 
Aboriginal child who is still in tune with their Burruguu-ngayi-li, or Dreaming, telling you that your teacher is lying ... yes, lying.

Remember back in Chapter 1 my writing how as a Pākehā, white kid in Aotearoa (New Zealand) I remember sitting in the class looking around at all the brown-skinned Polynesian and Māori children and thinking to myself, how lucky they were that we (white people) arrived and brought them civilisation - that we discovered their lands unused and gifted them agriculture and produce, taught them how to feed themselves and gave them an organised society. I would challenge any white person of my generation who did not feel such white privilege when being told of how agriculture was the beginning of civilisation and how it was spread globally due to Captain James Cook, Christopher Columbus, Cecil Rhodes and all the other great white explorers who pioneered the untamed wild lands of the new world. Just imagine if agriculture, rather than the beginning of civilisation, was actually the beginning of the end of civilisation ... to those Aboriginal people who have maintained our ties to the past prior to colonisation we certainly haven't witnessed any improvement. Rather than advancing human relationships with the land, agriculture has had dire consequences across the world in creating great drought, erosion, poverty and hardship. As a people who remember life before Europeans, we have observed the damage, where only now others are becoming aware.

The food crises results from the combined impacts of the industrialization and globalization of agriculture ... in early June 2008 an emergency meeting of the UN was called to address the crises of climate change and the food crises. As expected, the same corporate interests that have created the two crises tried to offer the disease as the cure - more fossil fuelbased chemical fertilizers, more non-renewable genetically engineered and hybrid seeds bred to respond to the intensive use of chemicals, more corporate control of food, and more globalized trade.

(Shiva, 2008, p.2)

As with the absence of Aboriginal history recently revealed in the last 40 years there is also growing evidence of agriculture not being the advancement in civilisation we once thought it was; in fact, as stated earlier, it may have even been the exact opposite.

The argument in The Food Crises in Prehistory (Cohen, 1977) grew in large part from the perception that extant theories of agricultural origins erred in a number of directions. They focussed on identifying particular 'hearths' where agriculture was independently invented and from where the various crops diffused. The commonly assumed hearths included Egypt, the Fertile Crescent, Mexico, Peru, possibly China and India, and the eastern United States. ... A common assumption was that the 'fortuitous' invention led to improvements in life, health and longevity by 
permitting populations to settle on one place, accumulate new technologies, and store resources. It also permitted communities to grow, opening the doors to civilization. In fact progress as largely undifferentiated monolithic pattern was generally assumed.

(Armelagos \& Cohen, 1984, p.xviii)

We only have to go as far back as Jared Diamond's famous book Guns, Germs and Steel (1998) to understand that along with these large settlement communities and the development of agriculture come the evolution of infectious crowd diseases with devastating effect. It is a reference which provides me an opportunity to introduce a direct reference via autobiographical ethnicity. Having now taken so many pages in just breaking down its definition, due to the lies and deception you have been told in the past, I can finally use autobiographical ethnicity directly. What you are about to read is how I visualise its use in a more practical sense, utilising aspects of traditional Kamilaroi storytelling.

I was driving my son to high school. He was attending a boarding school at 12 years old on a rugby union scholarship and we had just spent the weekend together. He was asking me questions as we were driving in regard to a social studies assignment he was to hand in later in the week, and began reading from his laptop.

As Europeans colonised the world the effects of world wide diseases had devastating effects on Indigenous peoples. Many died due to not having immunity to these diseases and unknowingly the European in wanting to bring civilisation to the world had brought also death and together with colonisation many Indigenous cultures vanished from the world ...

(Waters, 2012c)

I can't begin to explain the juggling act it takes when raising Aboriginal kids within a Western education system. You want them to understand that they have a separate and parallel reality from the other kids in the classroom. He was so proud, but it's a bit like being the parent of Peter Parker, knowing he is really Spiderman, or of Bruce Wayne, knowing he is Batman ... there is your identity within the school, as an Australian or New Zealander or any other Western country and you try to fit in ... but then there is this other identity you carry around with you unbeknown to people, hidden in the blackness of your identity. And just as with Peter Parker and Bruce Wayne, only those very close to you can ever know who you really are because as soon as you begin to reveal your true identity there are those who are out to silence you.

In this case despite his wonderful use of language - 'and unknowingly the European in wanting to bring civilisation to the world had brought also death...', he was always a gifted storyteller - that would only draw more attention rather than praise on this child of colour, particularly to those who 
celebrate colonisation as a European achievement, to be taught with pride. Just as with Peter Parker and Bruce Wayne, it was time to begin providing him with the tools against those who would try to persecute him, as if his being an excellent rugby player wasn't already enough, and out of jealousy try to hunt him down because he could also write beautiful prose; and just like Peter Parker and Bruce Wayne, trying to isolate him and take away his special powers and hide them from the rest of the world, the class and all those around him.

Like the other example of boys knowing the truth but not being able to articulate the lie, my son knew something bigger than school was going on, and for this reason he would constantly seek my approval. Like all cultures, we evolve and adapt and this juggling act between Western education and his Aboriginal identity becomes as important to his initiation rites as traditional ceremony and practice. The aim in educating my children is to provide them a path where they can use these superpowers in such a way to rise above and bring others along with them, rather than be persecuted, sent out of the class as troublemakers, and alienated. So far it appeared to be working: my son had led much debate in his class and only recently received an ' $\mathrm{A}$ ' for his 'Jesus was Black' assignment, carrying on a legacy from his older sister. Okay ... before I complete the story about my son let me travel back some ten years earlier when he was only two and his sister was seven years old. One of the most important superpowers Aboriginal people are blessed with is that we are not linear in how we see the world (Martin, 2008). I'll finish the story about my boy later.

Research has shown that we, or should I say those who still practise and retain an Aboriginal worldview, depend more on the right hemisphere of their brain, which is non-linear, more creative and spiritual as compared to the left side used by non-Aboriginal people which is more linear, logic and science based (Ross, 1982), meaning that non-Aboriginals who depend more on the left side of their brain struggle with multi-layered concepts and points of variation or alternative views other than their own (LeDoux, 1998). So before moving on to finish my son's story, we have to go back and forth within the narrative, playing with time and space, highlighting an even earlier event. My daughter was chosen to play Mary, the mother of Jesus, in her school play. It was an independent Catholic school so this was a pretty big deal and virtually everyone involved within the local school community was there, including local politicians and business leaders. The irony of what was about to happen was that my daughter, who is very Aboriginal in appearance, would have been a far truer and more accurate representation of what Mary would have looked like than most images we see in local department stores and films portraying the birth of a white baby Jesus (Ryan, 2016). Now because of the juggling act I spoke of earlier, my daughter had been exposed to a range of historical truths that lay well outside of any perceived truth or denial that continues to support white privilege and the superiority of the white race, with which the greater majority of this school hall in particular felt extremely comfortable. 
In a moment of pure emotion and adrenaline, no doubt coming from the right hemisphere of her brain, my daughter suddenly left the back of the stage before the curtains opened, went down to the pre-school attached to the school and swapped the white baby Jesus she had been given for a very dark Aboriginal baby doll, which she wrapped up and then returned to the back of the stage just as the curtains opened. You can imagine the shock of so many white Catholics at a private independent school still coming to terms with only recently having brown skin, black and Aboriginal children attend the school, when out walked a very brown mother Mary carrying her baby Jesus, his little feet sticking out from his robes the colour of burnt brass (Revelation 1:15).

Forget that this would have been the most accurate portrayal that the majority of this audience had ever seen representing the birth of the baby Jesus - remembering that truth has no place in the foundations and ongoing manipulation of a Western history that supports whiteness, therefore my little girl was quickly surrounded by irate parents, confused teachers and other community members demanding from her an answer, remembering she was only seven years old at the time. Whether Charlottesville, Kalgoorlie or a Donald Trump rally pre-election, the one thing they can never hide is their anger, no ... they really do reveal themselves. Anyway, in wanting to educate the audience and her school community towards the notion that Jesus was black, not white as we all but her had been told previously, by me the real guilty party ... and how she, remember still only seven years old, had unintentionally exposed white people to their own process of racial segregation and cultural amnesia - she was now ready and had decided it was time to have it named and exposed.

Fundamental to this historical amnesia was the neglect of Africa's crucial role in the development of modern religions. White Europeans and Americans, Du Bois insisted, whitened their religious faiths in order to justify the oppression and dehumanisation of people of colour. This was no more apparent than in whites' conception of Jesus of Nazareth. Roughly two millennia ago, Du Bois observed, there was born in the Egypto-Syrian area, with its Mongoloid and Negroid elements, a social reformer called Jesus Christ. Hypocritical white Europeans and Americans however refused to acknowledge that he was anything but white.

(Blum, 2005, p.368)

When Aboriginal people and people of colour expose racial difference, the mainstream or dominant culture becomes challenged. We have all heard the 'I don't see colour, I see people' statement that, rather that deconstruct oppression, in reality supports the notion of whiteness. You see the invisibility of whiteness has been manifest through everything to the point that it is accepted as normal. This is the way of the world, how I see it and accept it ... as a consequence of the very historical framework we were discussing earlier in the 
book and again in this chapter. Such normality, as seen through the eyes of the white and the privileged - who else gets to say 'they don't see colour ...?' denies any other colour than white as being accepted or normal. Whiteness therefore assumes the position of the 'uninterrogated space', therefore neutrality denies deconstruction of rhetorical events. 'Whiteness resided in its already defined position as everything and accepted as real' (Nakayama \& Krizek, 1995, p.293).

No doubt such explanations of colour have long been outmoded; what interests me is how they managed to touch on the construction of the ethnic categories of black and white in dominant representation. In the realm of categories, black is always marked as a colour (as the term 'coloured' egregiously acknowledges), and is always particularizing; whereas white is not anything really, not as an identity, not as a particularizing quality, because it is everything - white is no colour because it is all colours.

(Dyer, 2002, p.127)

When people of colour turn the tables in exposing social capital controlled by whites, this becomes 'a powerful and attractive strategy among those who have never quite belonged' (Ang, 2001, pp.10-11). By asserting her Aboriginality and blackness over and above what had been previously accepted as truth, that Jesus was white, my daughter had made audience members 'become very uncomfortable, agitated and upset' (DiAngelo, 2011, p.62). The irony, again, is that my daughter had created a scene of authenticity, so truth was not the problem here - it never has been; instead it is the inability for white people to accept truth, which has always been the problem. My daughter had also exposed that the mostly white audience also live in a bubble of racial segregation that supports their position as superior. Albeit such segregation is obscured in racially coded language such as seeking 'good schools' and 'good neighbourhoods' (DiAngelo, 2011, p.62). Such circumstance, as labelled by DiAngelo (2011, p.62): 'a (fragile) identity of racial innocence'. LeDoux (1998) explains how the phenomenon works in regard to left and right hemisphere use of the brain.

Explanations were based on response rather than knowledge of why the responses were produced [left hemisphere use] the patient was attributing explanations to situations as if he had introspective insight into the cause of the behaviour when in fact he did not. We concluded people normally do all sorts of things for reasons they are not consciously aware of (because the behaviour is produced by brain systems that operate unconsciously) and that one of the main jobs of consciousness is to keep our life tied together into a coherent story, a self-concept. It does this by generating explanations of behaviour on the basis of our self-image, 
memories of the past, expectations of the future, the present social situation and the physical environment in which the behaviour was produced.

(LeDoux, 1998, p.33)

It becomes clear that with non-Aboriginal people who use mainly the left hemisphere of the brain, responses and actions occur outside of a conscious awareness, as they are unable to relate to the Aboriginal experience. Rather than accept they simply do not know, or understand ... they instead demonstrate a strong reflective outcome based on what they perceive as truth in any given situation. Unfortunately such processing does not allow for conscious awareness or better understanding, and only confirms to them that they are right, whether or not they fully understand the situation, what has happened, or not.

Stimulus processing that does not reach awareness in the form of conscious content can nevertheless be stored implicitly or unconsciously and have important influences on thought and behaviour at some later time.

(LeDoux, 1998, p.33)

I went to support my daughter, but due to her having made a conscious decision, even as only a seven year old, I had to allow her to explain and negotiate a pathway out of the hostility she herself had created, rather ... the white audience had created, only she had chosen to challenge it. If things had got out of hand, of course I would have intervened, but again in referencing W.E.B. Du Bois (Blum, 2005), it was important for her own 'black strength identity of racial truth' to explain her own actions herself to the group.

Du Bois, in short, seemed to think that if the association of whiteness with godliness provided a rationale for racial oppression, then recognising the blackness of Christ, or at least his non-whiteness, might equip African Americans with another set of tools to counter exploitation and hatred.

(Blum, 2005, p.368)

I arrived just in time to hear the headmaster ask her why she had done what she did. Her answer was concise and to the point: 'because Jesus was black, sir ...' I have to admit that the headmaster did a good job of shutting down the groans of protest coming from those who had joined the inner circle, and once having shut them down, he asked her a second question: 'and how do you know this ...?' Again her answer was concise and to the point: 'because Tupac says that Jesus was black sir ...' Needless to say, my daughter had two teenage brothers who had impacted her with the wisdom and truth of this gangsta rapper, poet, wordsmith and prophet, Tupac Shakur. As this was an audience that had no appreciation of the social or cultural capital shared within the reference she had provided them, it was now time for me to step in. I introduced myself as working at a top Australian university, and of 
course was her father. I then explained that Tupac, rather than a rapper or musician which would only have confused, frustrated or even confirmed for some that my daughter was somehow 'bad' and/or a 'disruptive trouble maker', was an African American writer, philosopher, poet and scholar who represented black culture and identity, and was also considered one of the greatest writers of the 20th century (Stanford, 2011). The headmaster smiled, shook my daughter's hand, congratulated her for her bravery. My daughter would go on and have a brilliant school career, was an excellent student and went on to become the youngest ever graduate of the Australian public service graduate management programme, black or white (Waters, 2015). Oh, that's right, I almost forgot - I started telling you a story about her little brother.

So ... here I was dropping my son off at school, and he asked me a question regarding an assignment he was writing ...

\section{Note}

1 The black armband debate concerns whether or not accounts of Australian history revealing documented evidence of massacre and systematic erasing of Aboriginal culture and history are indeed true or instead gravitate towards an overly negative point of view. The black armband view of history was a phrase first used by Australian historian Geoffrey Blainey in his 1993 Sir John Latham Memorial Lecture to describe views of history which, he believed, posited that 'much of Australian history had been a disgrace', and which focused mainly on the treatment of minority groups, especially the mistreatment of Aboriginal people. The ultra-conservative and mainstream media accused historians who challenged Australia's white pioneering past with difficult truths revealed in journals and hand-written accounts and Aboriginal oral histories of an invasion since 1788, which were contested for focusing almost exclusively on official and unofficial imperialism, exploitation, ill treatment, colonial dispossession and cultural genocide, and ignoring positive aspects of Australia's history. 


\section{Nhuubala winanga-y-baa (A new hypothetical space ...)}

... So here I was seven years after watching my daughter educate white people about truth, history, Jesus Christ and everything else in between, but this time with her brother. Interesting that she was seven years old and he was 12 years ... I guess it's true what they say, that our girls mature earlier than our boys. I pulled the car over to the side of the road, an indication that we were about to have a very important conversation. My son closed his laptop and gave me his complete focus. My son has always thrived on his Aboriginality and blackness. 'It was not worldwide diseases that had a devastating effect on Aboriginal people across the world. It was European diseases', I told him. He looked back confused. I could remember writing the same assignment some 30 years earlier. It was time to tell the truth and start a little ripple to counter the waves of lies and deceit that had manipulated the generations before us a Kamilaroi father and son sitting in our car on the side of the road beginning our own process of decolonisation.

You can never estimate just how much such a ripple will influence our future, but as the father of a young black man with promise, heart and selfdriven belief motivated by righteousness, such conversations are paramount towards building our future. I spoke to my son firm in the belief that Tupac Shakur, Nelson Mandela and Marcus Garvey were all 12-year-old black boys at one point of their lives, and that somebody explained to them, no matter how hard, to face the truth about their history - their culture and their people. Together my son and I were about to throw a black curve ball in what had previously been accepted without hesitation in his education as truth. I told him the following ...

In coming into contact with blackfellas around the world, rather than share in our wisdom and knowledge, the White cultures of Europe stole our land through forceful occupation and bloodshed. They drained entire continents dry not understanding the sustainability and environmental issues in creating disease and poverty across the world. The only reason they are considered worldwide diseases today is because Europeans introduced them to the world. We didn't have diseases, we didn't even have the common cold. You know the old saying, 'bring out yah dead 
bring out yah dead' ... it comes from the black plague and the old song 'Ring a ring o' roses, we all fall down' ... the same. All European diseases, they were living in their own filth, son, living in their own shit, their excrement, they were polluted, over-populated and they were escaping ruin, not bringing civilisation, how could they bring civilisation when we were already civilised. That's what really happened, son ... these diseases originated from people living in open sewage, pollution, eating raw meat not fully cooked with no idea of sustainability and environment or wellbeing ... add to that that they were violent, savage people. No, son, these were not worldwide diseases, these were European diseases spread throughout the world like a cancer ...

(Waters, 2012a)

Another superpower Aboriginal people once possessed, rooted deep in ceremony and ritual practised over tens of thousands of years, was that we maintained a truth ... I know it's hard to believe in this day and age of posttruth (Suiter, 2016), but we were so steeped in tradition, understanding the land and controlled by maintaining our environment you just didn't have the opportunity to deceive one another, you just couldn't afford to ... the results would be catastrophic. Even today, when we learn the traditional ritualistic dances as part of our initiation ceremonies there is just no opportunity even for individual expression - because these steps, these moves have to be exact as they were handed down, with no room for interpretation. Why? Because we believe, and I still do despite having a $\mathrm{PhD}$, as do many other Blackfellas, that these ceremonies come to us handed down by Maran Dhinabarra (ancestral beings ...) ordained from within creation. In talking with many Aboriginal people today this is also what separates us, apart from social and cultural capital, social mobility and personal agency there are some who in finding acceptance within the secular societies of the West no longer feel this same connection. But for me, and many others, my winanga-y-la-nhi (consciousness ...) originates long before I was born, handed down from our creation before we were in a physical realm. I remember as a young person that our parents on the communities would tell you, 'ngiyaningu maran yaliwunga ngarra-li (our ancestors are always watching ...), don't you lie ... don't you steal ... you may think you got away with it but they see and hear everything you do ...' I understand how difficult that is to believe in this day and age, but we believed that. You just would not dare lie ... you just wouldn't. This was confused by whites as simple tribalism, fear of persecution through 'black magic', but just like our never having seen or experienced a common cold or sneezing, we just didn't know what it was to be dishonest. Even today we say 'true God ...' to one another as an affirmation of the truth used in intensifying an adverb. Now some of our children, and others having grown up in a world of secularisation in moving away from ritualistic beliefs, say 'true dat' rather than true God, but it still survives in expressing a collective strong conviction towards agreement as truth (Victor \& Dalzell, 2007, 
p.667). Such truth was exposed by Europeans as our lacking a sense of sophistication, as superstition, and as I said, a fear of 'black magic' - but it didn't take long where our history soon become riddled with agreements broken by white governments and individuals representing vested interest in the exploitation of Aboriginal resources speaking with 'forked tongue' (Miller, 1991, p.543). We as 'Indigenous' people like them have been lying ever since, and it's killing us literally as we become disconnected from the truth. By truth, what I mean is in representing who we really are, and what we believe in as Aboriginal people that makes us unique from the West. The truth I was now sharing with my son, in our car parked on the side of the road, related to the fact that rather than Europeans representing a great civilisation, we observed them as very primitive. These were people living in their own excrement. They quickly over-populated and destroyed large, sustainable, cultivated, eco-friendly land areas and were savage in their interaction and inhumanity in displaying horrific violence without reason. As devastating as our history has been due to European invaders, what I was now explaining to my son was the enormity of numbers we lost due to microbes contained in murderous diseases carried by white Europeans due their very primitive existence. There was a time when microbes would have to wait for one host to be eaten by the next as salmonella bacteria, which would then be 'contracted by eating already infected eggs or meat; the worm responsible patiently waiting in an animal to be killed and then eaten without properly cooking it' (Diamond, 1998, p.198). These bugs were at first contained and then spread through Europe, bypassing the need to be eaten, instead transmitted passively from a host to victim due to the open sewage and filth Europeans were then living in (Diamond, 1992). That's right, not worldwide diseases at all, but instead, as I was now telling my son ... the most infectious diseases in the world were spread by Europeans eating uncooked meat and then living and sleeping within their own shit. That was what they called civilisation. These microbes continued to evolve and a slight modification occurred allowing even more to spread, now able to hitchhike via insects biting the old host and then flying to bite another victim who became infected as the microbes were carried in the insect saliva. The spread of disease via mosquitoes, fleas, lice, or tsetse flies, was the cause for the spread of malaria, plague, typhus, and sleeping sickness, with devastating effects upon the Aboriginal peoples of the world. The white Europeans even used these diseases as an intentional form of biological warfare, to wipe out entire Aboriginal populations, such was their savagery and barbarism.

The skin lesions cause by smallpox similarly spread microbes by direct or indirect body content (occasionally very direct, as when U.S. whites bent on wiping out 'belligerent' Native Americans sent them gifts of blankets previously used by smallpox patients).

(Diamond, 1998, p.199) 
How can anyone refer to such people as civilised ...? Smallpox was also used as biological warfare in Australia, contained within the First Fleet and 'captured in the journal of marine captain Watkin Tench' who describes vividly smallpox being carried in bottles (Warren, 2014).

We can be confident that the spread of smallpox was authorised by senior officials because it occurred on the opposite side of the harbour from the settlement. This indicates that boats were used for smallpox deployment, which would have required official planning and sanction because any marines leaving Sydney Cove without permission were court-martialled. Aboriginal traditions tend to support this analysis. In 1820 William Charles Wentworth noted that the story of the outbreak would be re-told in traditional songs for a long time.

(Warren, 2014)

The greatest single epidemic in human history was the influenza epidemic that killed 21 million people at the end of the First World War in 1918. Then there was the Black Death, or bubonic plague, which killed one quarter of Europe's population between 1346 and 1352, with death tolls up to 70 per cent in some cities. Evidence from studies has identified that the agents of these infectious crowd diseases originated from confined spaces of domestic and farming animals. Agriculture again, rather than increased civilisation, becoming the perfect incubator to store and spread these diseases at great cost to human life (Diamond, 1992). Where such diseases were once confined to wild animals, this was no longer the case due to agriculture and its need to domesticate farm animals such as cows and pigs requiring dense populations, and with animals already afflicted by epidemic diseases it was just a matter of time before being transferred to humans with disastrous effects. Again it was contact with the animal excrement and sleeping in close quarters with the animals that spread the disease to humans. Whereas Aboriginal nations had highly advanced classification and systematic use of animals as part of their understanding of biodiversity and sustainable cultivation methods including habitat, as discussed in Waddy's biological classification study including animal and fauna taken from the Groote Eylandt Aboriginal community in 1982.

there was no way in which this division could be deleted, despite my informants' awareness of the need to stick to purely animal classification without interference from special purpose uses such as food source. To me it seems that habitat must be accepted as a valid factor influencing folk biological classification. At least for the Groote Eylandt Aborigine at this level of inclusiveness, habitat cannot be dismissed as interference from a special purpose classification.

(Waddy, 1982, p.73) 
The historical importance of such animal-derived diseases carried by a people living next to open raw sewage has been lost in glorifying the pioneering myth of settler communities. It was to play a key role in slaughtering Aboriginal nations across the world, including Pacific Islanders, our own Australian Aboriginal people, the First Nation American peoples and in Africa. As these were black and Aboriginal people, the tragedy of the crises has never been fully accepted or taught, but in reality there were circumstances where as many as 50 per cent to 100 per cent of entire populations were wiped out.

the Indian population of Hispaniola declined from around 8 million, when Columbus arrived in A.D. 1492, to zero by 1535. Measles reached Fiji with a Fijian returning from a visit to Australia in 1875, and proceeded to kill about one-quarter of all Fijians then alive (after most Fijians had already been killed by epidemics beginning with the first European visit in 1791).

(Diamond, 1998, pp.213-214)

Diamond (1998) states that the Hawaiian population went from 500,000 to a mere 84,000 in 74 years between 1779 and 1853 before another 10,000 lives were lost due to the introduction of smallpox. This one-sided exchange of lethal germs between the white European invaders and the Aboriginal people of the world is among the most striking and consequential facts denied in recent history ... the simple truth, that we were not exchanging diseases back in return because we were living disease-free. This was due to the systematic classification and use of animals in our biodiverse cultivation systems of environmental land management, together with an awareness of hygiene and understanding of clean living so absent throughout Europe. Yes, having survived, retained my language and connection to my knowledge systems, I am here to tell you, in writing this book, that we were living in a cleaner society, more civilised ... and yes ... aware. We just didn't have the germs originating in our worlds where land was sacred, organisational structures were more ecological, and in particular our awareness of issues involving sustainability were highly developed, having been managed over thousands of years. Priorities were clean air, clean waters and substantial cultivated land estates, not as hunter-gatherers but as sophisticated farmers, in understanding diversity, permaculture, together with biodiversity and sensitive land management.

The issue of open sewage and disease is particularly interesting as there are many stories within Aboriginal history that talk about human excretion having to be probably managed due to a fear of 'becoming sick' and the consequences if not probably treated. There is a scene in the 2006 Australian feature film Ten Canoes, directed by Rolf de Heer and Peter Djigirr and based on conversations with acclaimed Aboriginal actor and ceremonial man David Gulpilil, that highlights this. The film is set in Arnhem Land, before Western contact, and is the first Australian movie entirely filmed in an Australian 
Aboriginal language. The scene I am talking about clearly shows the fear of local men in the tribe when a stranger appears on their traditional homelands in regard to the systematic erasing of human excretion, and in particular the consequences that can occur if we are to come into contact with it. Under the guise of superstition and witchcraft created for a Western audience not attuned to deeper multi-layered Aboriginal meaning, the stranger is shown through a slightly different filter over the camera. The men are worried that the stranger may find their 'poo' to work 'magic' against them and each one is concerned to make sure this excrement has been properly disposed of, ensuring it will never come into contact with humans. In confronting the stranger there is a graphic scene of bloody murder, which is confronting and shocks the viewer. The point is that excrement is to be disposed of, covered, never to come into contact again. It must be treated accordingly. The magic and superstition dictate that it has the power to make you very sick, even cause death (Language Matters, 2011).

Growing up on the mission as a small child I was always told walk away, find a secret place safe to goonah (shit) and cover it up, make sure no one knows where it is and always go back to that same spot, don't spread it around. It was the same with spit, saliva, blood, even your hair and nails, don't let anyone find these things, them old people will tell you they can make you sick, even dead. See even today people don't realise sorcery makes you sick, all these diseases today, even cancer and AIDS, come from sorcery, they were not always there, they come from somewhere. People with no connection to ancestral beings, their lineage or language, with no understanding of deeper things laugh it off as witchcraft, but we never brought the diseases, they did ... not us, them.

(Spearim, 2012)

The stranger in Ten Canoes is not accepted. He does not belong to the tribe because he comes from a different place. The problem here is in translation, where magic, or sorcery, is the closest interpretation in English to what we in Kamilaroi refer to as Muuliyaay. Rather than be dismissed as nonsense, muuliyaay (not right, not in place ...) is an extremely sophisticated understanding of metaphysics, a branch of philosophy exploring the fundamental nature of reality - the first principles of all things, including concepts such as being, knowing, identity, time and space, which though they remain abstract within the West, are intricately understood and defined within Kamilaroi ontology. Just as early Europeans scoffed then at the idea of interconnection, genetic and collective memory as essential to our understanding of the world, these are ideas that only now are being explored and understood within Western science. Muuliyaay or magic is then another example of misunderstanding lost in translation, no different to Burruguu-ngayi-li and Dreaming ... 
Every afternoon, the old men of the tribes gather at the outskirts of their camp just north of Elliott and chant the Gudjiga, a cycle of sacred songs that name and claim and care for the land and its people. A town like Elliott defines its own reality. 400 Aborigines abiding by the old law and singing the land every day create something much stronger than the ragged Western rationality of 40 white misfits constantly sedated by alcohol or Valium. When the old men say their tribe was created from the mud made by the Giant Dingo pissing on the hot desert dirt, even the most cynical bureaucrats just nod, knowing they cannot prove any different. The old magic is still strong. When you're sung, you stay sung, black or white ... He climbed out of bed and opened the door to the unexpected aroma of rain and the sight of huge raindrops plopping onto the dead leaves that littered his front yard. The unseasonal and unexpected rain made Terry realise that Louis never was wild or wicked or even a lucky bastard. He just bore the burden of this time ... and this place ... in ways he would never understand. He'd been sucked into the spin of another universe and when the wheels came off, he just kept grinding away.

(Stockwell, 1994, pp.40-45)

It is of little surprise that with first contact, when we witness for the first time our people with eyes turning red, sneezing, and hundreds of thousands dying around us, that we would attribute the cause and effect to muuliyaay misinterpreted by early Europeans as magic. One of the biggest impacts on the Australian Aboriginal population was in the City of Yarra in Victoria with up to 'sixty per cent of the local Wurundjeri population lost to disease' (Presland, 1985, p.90). The spread of disease 'was even faster than the spread of the Europeans with up to a third of the Aboriginal population killed by an epidemic of smallpox before the whites began arriving in the local area' (Edmonds, 2010, p.27). In addition to smallpox, there were other 'diseases introduced intentionally such as tuberculosis and venereal diseases including syphilis' (Christie, 1979, p.43). Starvation was also killing our people in rapid numbers.

Once whites occupied land and cleared local farming and food harvesting areas changes to diet also became a source of ill health and disease. The forced adoption of a European style diet, including refined sugar, flour and offal, replacing what had been a high protein diet was made worse by the provision of rations that consisted of the worst quality and cheapest grains and meats available.

(Christie, 1979, p.43)

The eco-friendly environmental cultivation of land, together with the systematic classification and use of animals as a staple diet that had prevented 
disease for thousands of years was eradicated almost as quickly as the diseaseridden whites had arrived.

Traditional hunting lands were fenced off, Europeans were systematic in their pursuit and intentional killing of Aboriginal families now forced into fringe areas and native animals were also shot for sport. The introduction of hoofed animals such as sheep, which trampled and destroyed native plants that had also served as part of this staple diet, was critical. With the natural food production cut off the local Wurundjeri were forced to become dependent upon European settlements for food, which led to gatherings of more Aboriginal people in city centres, which in turn facilitated spread of disease.

(Clark \& Kostanski, 2006, pp.68-69)

It is difficult to describe the look on a young Aboriginal boy's face, who desperately wants to fit into society, be part of the mainstream community like all the other kids - proud to be Australian, represent his school in sport and stand for the national anthem - when they discover the truth denied to them in classrooms of deceit. As I keep saying, negotiating such a child's journey through adolescence is a juggling act. I am fully aware that at any time I could lose a highly focused student aspiring for excellence on a rugby scholarship at a top private school with all the other black kids who think 'walk away', turning their back on a system that denies their true beauty. As their potential is regulated to a deficit approach where they are expected to fail ... so those with capacity become lost, instead immersed within their own ethnic localism rather than choosing to remain alienated within a mainstream environment that ignores them.

Through ideas such as local 'economies of mobility', 'cultures of violence' and 'meanings of success' we sought to capture the extent to which locality provides more than a backdrop for young people's lives, but also the collective context that shapes values and meanings - what Bourdieu described as a 'logic of practice' (Bourdieu, 1977). Individual young people are not determined by their localities, yet their options and identities are constrained or enabled by them.

(Henderson et al., 2012, p.14)

We lose too many kids with entrepreneurial and leadership qualities who instead become drug dealers or worse, due to the cultural, religious and political identities immersed as the only viable options in some of their communities. Unlike seeing role models of themselves in education or among those who run legitimate businesses, as discussed when I purchased a car and rented a house from my extended white family and community. Unfortunately many of these young people's construction of self and influence are determined by a lack of opportunity within their communities as they transition 


\section{2}

Nhuubala winanga-y-baa

into adulthood (Henderson et al., 2012). Long before I became a respected scholar and published writer ... I'm talking during my teens ... my identity was formed and embedded from deep within the confines of the 'Stolen Generation', stamped within oppression, abuse and separation. Here, among the indignity and poverty of the Australian public housing system, substance abuse becomes substance relief and I found myself dealing in that relief. Here I would receive acknowledgement from other drug dealers; a simple nod of the head at parties, gatherings, or just walking down the street. This was my identity. You see, in the world of teenage Aboriginal public housing in Australia that I grew up in, you were either doing drugs or dealing drugs ... and if you dealt drugs, and didn't smoke your own supply, it meant you were in control ... I was always in control. It has been a long and traumatic journey where I now receive that same nod of recognition from distinguished gentlemen with silver hair like mine as I walk through the university.

For me personally, that precise moment of inspiration - who or what is reckoned to be 'breathing into' whom or what, and to what effect - has been played out over a number of different times throughout my life. Which, upon reflection, become strategic signposts, perhaps at times when the Maran Dhinabarra (ancestral beings ...) are with me, looking out for me ... which again creates for me a sense of autobiographical ethnicity rather than a feeling of disenfranchisement or alienation. It is within this very faith system that I feel most connected to my Aboriginality ... and it is for me and my connection to my traditional Burruguu-ngayi-li or 'Dreaming' that truly separates autobiographical ethnicity from current Indigenous studies and also from ethnography. As stated previously, as an Aboriginal person I ask you ... do you honestly believe you are descended from ancestral beings tied directly to the DNA of your traditional country and homelands or not ...? It's not difficult, either you believe you are ... or you do not. Any other concept, idea or worldview, no matter how secular, or sophisticated, hidden within the intellectual boundaries of academic writing, or with its origins outside of our communities, simply doesn't formulate our knowledge our way. It is a point of discussion raised by Jennifer Houston (2007, p.42), who when talking about autoethnography, states:

born out of the crisis of representation motivated by a post-modern consciousness ... [autoethnography] is reflective of the discontentment of traditional research practices ... as the only way to understand and interpret human experience.

(Houston, 2007, p.41)

If ethnicity is also a social construction, both black and white, Indigenous and non-Indigenous beyond just a link of blood (Baumann, 1999), more to do with boundary maintenance and asserting difference than a celebration of sameness as asserted by Fawcett and Campling (2000) - then it becomes imperative that you negotiate truth with sensitivity when managing black 
youth. So here in our car, in unravelling the spread of disease by Europeans I am also uncovering yet another great lie told to my son by those who record white history, and that is in introducing my son to perhaps the best-kept lie in white history ... the black holocaust of colonisation and slavery. It's one of those moments, you have them a lot as a parent, when aware a wound has already been opened, you have to make a decision ... do I stop here or do I keep going? He was silent; he looked at me with upmost attention and was hanging on every word. He was listening - I had to keep going. There are no actual numbers or accurate estimates I could give him, despite the range of varied sources available to me in consideration of just how many of our black people died globally. That in itself is a frightening thought. You have to break numbers down first to those who died through slavery (Stannard, 1993), and then colonisation, frontier wars and also invasion (Tharoor, 2016). The reason being that in what research I have found, the two - slavery and colonisation are not listed together; and finally, what had started this discussion in having to also consider biological warfare, both intentional and unintentional, through the spread of influenza and other viruses (Jalata, 2013). When you add the three together you start getting some idea of the devastation caused to black and Aboriginal races around the world. What makes this significant is that this grieving and loss still remains as mourning deep within our communities, and that part of this grief is in that there is little to no remembrance or ceremony of those we lost in the annals of white history. It's a bit like revealing to your children the deception behind first the Tooth Fairy and then Santa Claus but maintaining fear in the Bogeyman ... it was time to come clean.

The Spanish conquistadors alone killed an estimated 95 per cent of the New World's pre-Columbian Indian population (Diamond, 1992), and it was white Christian Europeans who in turn created the largest slave trade in the history of the world. Yes, people who called themselves Christians would kill an estimated 60 million Africans before they were done (Stannard, 1993). On second thoughts, I realised in talking with my boy that though Santa and the Tooth Fairy were very much lies and deception ... the Boogeyman was unfortunately very real. A key reason for the high death toll was the tidal wave of war and desolation that the slave trade unleashed into the heart of Africa. Huge numbers of people died being marched to the coasts of Africa to become accessible to the slave ships as well as an endless series of wars produced in building the financial capital acquired from new slaves. Millions more would die in concentration camps at both ends of the sea journey, and significant numbers would die due to the appalling conditions on these slave ships. We had the same concentration camps in Australia, where in Tasmania people were forced into ocean-front small sheds after being forced out into the water and locked in overnight with raised walls from the floor causing draughts. Having no immunity to influenza, such strategies resulted in what has been written as a systematic and intentional form of Aboriginal genocide (Lawson, 2014). 
the sheer fact that story of genocide in Tasmania has been so well worn in Britain from the 1820s onwards is itself of crucial importance. The 'Black War' between colonists and the indigenous peoples of Van Diemens's Land, and the idea that the latter had been exterminated, was culturally significant in Britain during the nineteenth century and remained so since, albeit somewhat less prominently. Indeed this book seeks to demonstrate that this is a genocide that has become part of British identity.

(Lawson, 2014, p.xx)

Within and outside of Australia the Tasmanian genocide has become part of British identity and then in its denial also on behalf of the colonial loyalists. Australian historians such as Keith Windschuttle deny not only the act of genocide in Tasmania and other parts of Australia, but also question whether the now infamous 'Stolen Generation' ever existed 'at all' (Lawson, 2014, p.16), which speaks volumes of the conservative ultra-right in Australia. Then there is Rottenest Island, documented in John Pilger's 2012 documentary film Utopia, in Western Australia, which was used as recently as 1931 as a concentration camp for Aboriginal people who were held there before their execution. Rottenest Island now has cells which have been converted into suites within a luxury hotel and spa complex as part of a major tourist attraction (Pilger \& Lowry, 2013).

Across the rest of the world no one knows the exact number of slaves who died, but in American Holocaust (1993), David Stannard estimates that some 30 to 60 million Africans died while being enslaved. He claims a 50 per cent mortality rate among new slaves while being gathered and stored in Africa, a 10 per cent mortality rate among the survivors while sea crossing, and another 50 per cent mortality rate in the first 'seasoning' or breaking-in phase of slave labour. None of the above takes into account the devastation afforded also to the Indian subcontinent under British rule, where it is estimated that as many as 3.5 million Indians were forcibly moved across the globe as part of the 'colonial project' as indentured labour to the Caribbean, South Africa and Fiji (Tharoor, 2016, p.192). Again, it is hard to give accurate figures, which is why we are dealing in estimates as no detailed records have been maintained throughout history - quite simply, this is because those who lost their lives were not considered human, they were sub-human. There were, though, accurate records taken and found from the year 1856-57 and the one route of Kolkata to Trinidad, which gives us a very important and shocking insight. Here the percentage of death of indentured labour on the transporter ships was appalling: 12.3 per cent of males and 18.5 per cent of females, 31 per cent of boys and 36 per cent of girls, and a tragic 55 per cent of infants (Tharoor, 2016, pp.192-193) perished. All of which are much higher than David Stannard's estimated figures for African slavery, the reason being that in dealing with genocide of Aboriginal people, due to the anxiety and scrutiny of historians like Keith Windschuttle in Australia, historians tend to err on the side of caution. The idea of indentured labour, which creates an illusion of 
choice beyond slavery, is ridiculous as the Indians were leaving economies destroyed by the British, their way of life devastated and they were starving to death ... hardly any choice, death by starving or the lottery of life and death as an indentured Indian forced to cross to the other side of the world. When you average out the percentage of death within the different age groups you are given a haunting figure of 30.56 per cent for the one year taken. If we were to add that figure over the duration and break down a percentage from the 3.5 million taken collectively, that would give us a figure over 1,069,000 people killed as indentured forced Indian labour. This, of course, does not include those who died upon arrival or those who died of starvation who stayed.

In respect also of my Irish heritage, I also wanted to include the Irish in this written remembrance of those who died as slaves to a European Christian society. Unfortunately, rather than accurate commemoration of Irish deaths sacrificed, what is instead clearly evidenced is the dividing up of Irish lands being given to the British. To find accurate numbers of Irish dead is difficult, but title to Irish lands - as the Penal Laws of the early 1700s allowed the British to take the lands of Catholics who refused to become Protestants - is well documented. Again showing the complete disregard for human life over and above the commodity of the slave trade and stolen lands. What has survived from Ireland, as with other cases cited throughout this book, and in particular the oral histories as autobiographical ethnicity of my own Aboriginal people in Australia, is the testimony of the victim having run parallel to that of the oppressor. Thanks to the Irish scribes themselves, history is not able to hide completely the horrific bloodshed suffered by the Irish. During the 17 th century, beginning with the Irish Rebellion of 1641 against the domination of English and Protestant settlers, we see the introduction of Oliver Cromwell during 1649-53. Cromwell joins the names of many others revered throughout history, honoured as great men who pioneered European and British history. The truth is otherwise. Cromwell's conquest of Ireland was nothing more than a brutal display of inhumanity and genocide under the declaration of war where by the end of his slaughter there remains, again thanks to the Irish, not the English ... well-documented evidence of up to a third of Ireland's population left dead, dying or in exile.

Upon serious consideration had of the great multitudes of poore swarming in all parts of this nacion, occasioned by devastation of the country, and by the habits of licentiousness and idleness which the generality of the people have acquired in the time of this rebellion; insomuch that frequently some are found feeding on carrion and weeds - some starved in the highways and many times poor children who lost their parents, or have been deserted by them, are found exposed to, and some fed upon, by ravening wolves and other beasts and birds of prey.

(Printed Declaration of the Council, 12 May 1653, A (84) 1 p.138) 


\section{6}

Nhuubala winanga-y-baa

Cromwell's legacy after burning crops and destroying everything in his path was to lay the foundation towards the Irish being seen as sub-human as 'another 2 million would die' as a result of the Irish Potato Famine from 1845 to 1850 , when the British government enforced a policy of mass starvation with intent to destroy the Irish people en masse (MacGeoghegan \& Mitchell, 1868, p.204).

IRELAND, in the language of Scripture now lay void as a wilderness. Five-sixths of her people had perished. Women and children were found daily perishing in ditches, starved. The bodies of many wandering orphans, whose fathers had embarked for Spain, and whose mothers had died of famine had swept away whole countries, that a man might travel twenty or thirty miles and not see a living creature.

(Prendergast, 1865, p.196)

Just stop and visualise the living hell described above ... again how anyone can state that the perpetrators of such savagery were civilised is beyond me. What should have been labelled as genocide is most often referred to throughout history as the great 'Potato Famine', again denying Britain's culpability. The famine followed two centuries of land theft by the English invaders - yes, invaders ... not colonialists, not settlers, but a hostile, aggressive, brutal invasion. The Irish were left with extremely small parcels of land where crops such as wheat, grain and barley were exported to the landowners of Britain. As a consequence the Irish became dependent on the potato for survival. The large landowners were Protestant gentry who shipped all of their agricultural produce to England to keep food prices low there, allowing the Irish to starve when the potato crops failed because of disease again playing a crucial role. As a result, millions of Irish starved, the English were well fed at low prices with more than enough food produced in Ireland to avoid the famine. The decision to ship all food to England was made by officials in the English Treasury, knowing millions were starving in Ireland. In doing so over 2 million starved while others were forced to emigrate as indentured slave labour.

Tell us not that it was beyond the power of the combinations, which the strength of the British empire could have wielded, to have brought to the ports of Ireland subsistence for all her people ... Britain is now branded as the only civilized nation which would permit her subjects to perish of famine, without making a national effort to supply them with food.

(Dublin University Magazine, 1847)

The Penal Laws, first passed in 1695 after Cromwell, were strictly enforced. These laws made it illegal for Irish Catholics to own land, requiring the transfer of property to English Protestants. As with other British invasions around the world, the Irish were not granted access to an education, and their 
native tongue of Gaelic was outlawed as a language. The Irish were forced into leasing agreements in order to remain as sharecropping farmers on their own land now owned by the English. Irish Catholics could not vote, hold office, purchase land, join the army, or engage in commerce. Simply put, the English turned the Irish into nothing better than slaves, subsisting on their small rented farms, feeding the English. At the time, just as colonialist historians do presently, the English refused to take responsibility, instead employing an effective strategy of blaming the victim, which we still see being played out in ultra-conservative, neo-colonial white cultures today.

A diseased nation, subject to paroxysms of in-sanity, and requiring 30,000 keepers, was a dangerous neighbour, as well as a serious financial burden. Yet many contended that all such attempts were useless. It was like trying different kinds of soap to whiten the skin of a negro. The patient was incurable. Her ailment was nothing but natural perversity, aggravated by religious delusions; and the root of her disorder could never be known till she was subjected to a post mortem examination, for which it was hoped emigration, and the help of improving landlords, would soon afford an opportunity. In the meantime, the strait waistcoat must be put on, to keep the patient from doing mischief.

(Godkin, 1870, p.vi)

Now compare the above, written 150 years ago, with an article published only this year in The Australian - yes, The Australian again ... no surprises there - by Gary Johns in regard to the Royal Commission into the Protection and Detention of Children in the Northern Territory. The commission was established after it was revealed that Aboriginal children in youth detention as young as ten years old were being systematically tortured and abused by white staff:

threatened with rape, compelled to shower with adult inmates, forced to sleep naked in wet cells, teenage girls forced to strip naked in front of male guards, tear gassed forced to wear spit masks and restrained for days at a time all the time being labelled dumb black kids ...

(Maxwell, 2017, p.1)

Now the excerpt from Gary Johns's article for The Australian:

The commission also says communities need to participate in decisions that affect them. Name the last time your 'community' was 'consulted'. The reason is that we are competent to manage our lives and do not, as a starting point, rely on government services. And the clincher, of course, is that 'communities and experts' have told the commission about the importance of 'maintaining and strengthening connection to land and culture' as 'a protective factor' for young Aborigines. Would this be the 
culture that lauds violence to settle disputes; humbugging, that is, bludging off family; sorcery; and forced teenage marriage to old men.

(Johns, 2017)

Such commentary as we are witnessing around the world with the growth of white fragility as a form of white supremacy fails to consider historical context, issues of cause and effect, and remains steeped in denial. It continues a sense of blame associated with the victim rather than the perpetrator. Thankfully, as one voice dominates white ... sorry, 'right'-wing conservatism over the centuries, another more balanced, humane voice has over time provided a deeper, more intellectual response:

Mr. Gladstone understands the case of Ireland, and he has courage to apply the proper remedies. Yet the British public do not understand it so well; and he will need all the force of public opinion to sustain him and his cabinet in the work of national regeneration which they have undertaken. It is not enough for a good physician to examine the symptoms of his patient. He must have a full and faithful history of the case. He must know how the disease originated, and how it was treated. If injuries were inflicted, he must know under what circumstances, how they affected the nervous system, and whether there may not be surrounding influences which prevent the restoration of health, or some nuisance that poisons the atmosphere.

(Godkin, 1870, pp.vi-vii)

I wrote earlier about my experiences on Aboriginal sovereign lands belonging to the Maroon people of Jamaica. I now move towards the end of this present chapter again on sovereign Aboriginal lands, but this time writing from within the Ngāti Kahungunu Māori lands of Hawkes Bay in Aotearoa New Zealand. The Māori, through the treaty of Waitangi signed in 1840, demonstrate unity and strength in displaying what they themselves call mana (legal, effectual, binding, authority), displaying prestige, authority, control, power and influence over New Zealand's national identity and consciousness. It is here among the Ngāti Kahungunu that I have found a bastion to write, away from the racism of Australia, still the only Commonwealth country in the world with no agreement, acknowledgment or treaty with its Aboriginal people. As privileged as I am to be on traditional Māori lands, this does not mean that they have not suffered also at the hands of European invaders. As with my Polynesian, Samoan, Tongan and Pacific Island brothers and sisters from the Cook Islands and Fiji, these areas too have been devastated by white invasion. Their pain, in writing on Māori land, has to be also acknowledged in completing this chapter of the book. I could also not finish such a chapter without a declaration of acknowledgment in regard to the 'Shoah', the Jewish Holocaust. I want to make it clear I mean no disrespect, and I am not degrading the Shoah by using the term genocide in regard to my own black 
people across the world. Not when such suffering has occurred across the globe with so many million people inflicted within this same pain over collective centuries due to slavery and colonisation. Let us be fair in saying that it is from the backs of slaves and stolen Aboriginal lands that we have built Western civilisation. That many of the same conservatives who deny the Aboriginal invasion and attempted genocide, to even question the stolen Generations as ever having happened, and to then use the Jewish Holocaust to deny this pain - in giving no remembrance to those who have fallen, is only testament to their lack of humanity and sensitivity. No one race, people or life should ever mean more than another in a truly civilised society, but unfortunately scholars like Inga Clendinnen remain adamant in their rejection of the term genocide being used to document black deaths over white ...

I am reasonably sophisticated in these modes of intellectual discussion, but when I see the word 'genocide' I still see Gypsies and Jews being herded into trains, into pits, into ravines, and behind them shadowy figures of Armenian women and children being marched into the desert by armed men. I see deliberate mass murder.

(Clendinnen, in Lawson, 2014, p.16)

Encapsulated by many conservatives who object to the term genocide being used in the case of Australia and other black holocaust across the globe, they are only denying history driven by guilt, in so much that surely 'genocide was only committed by Nazis and not by us', which is based on a sense not of what history was but instead of what it was not. It is important to note, as documented within this chapter, that associated with white European invasion was the systematic mass murder and killing, be it by disease or gun, of Aboriginal people who had their lands stolen and resources exploited, and for what ...? In building the wealth of the West as we know it today. As stated by Lawson (2014, p.23), '[a]lthough it might be to overstate the case, it is worth remembering that Jews who died of typhus in Auschwitz were victims of genocide just like those who died in gas chambers', so yes, those Aboriginal people who died through disease must also be included in the killing. Lawson then goes even further in defending the use of the term genocide when remembering my own Aboriginal people ...

the British government knew explicitly that it had unleashed a destructive process that would eradicate those societies. Its representatives disavowed, and indeed even regretted, the exterminatory impacts of their presence, yet they never faltered, never sought to roll back colonial development. Indeed, they even developed an understanding of the world that saw as inevitable the dying out of 'inferior' indigenous races. It is for these reasons that I believe that the term genocide is conceptually important and applicable in the Tasmanian [Australia] case. Furthermore, I think it is 
even possible to identify a genocidal plan, and genocidal intent, thereby satisfying a more essentialist definition of genocide.

(Lawson, 2014, p.23)

Whether the Jewish Shoah, the African holocaust or the Aboriginal genocide, the Irish famine or the indentured labour of India, or the mass loss of lives in the Pacific Islands and Aotearoa New Zealand, the events related in this book, the piles of bodies of which I write, were the result of one of three things: first, economic policies by a colonial power; second, the commodification of natural resources and the wealth stolen from Aboriginal peoples including slavery; and third, the outright murder and intentional killing of millions across the world in frontier wars. The events of the Jewish Holocaust or Shoah were as a result of a social policy where peoples were killed for their social undesirability by the Nazis. Whether it be through economic or social policy or just plain murder through mass killing in both the Jewish Shoah and the black holocaust, the bodies piled up and the results for the peoples affected were the same. Their property went to the state and the result for affected families and people was the devastation of mass murder and despair holding on to a lineage of trauma. As Kamilaroi, I believe in a genetic memory, a collective consciousness that dates back to my creation. A living soul connected to the universe and my emotional wellbeing. I have stated these beliefs firmly throughout this text.

When I think of the use of smallpox as biological warfare committing ethnocide, mass unmarked graves, slavery and lynching, infants dying on slave ships, and people defending such action in refusing to use the word genocide because it offends them ... feeling justified because the intent was not to kill the entire race and still today remaining loyal monarchists to a British flag drenched in my people's blood - a flag responsible for the mass murder of millions of people across the globe ... as a black man, as Irish and Australian Aboriginal, which as I have declared is how I am writing the text through my own autobiographical ethnicity, with my first voice, narrative and representation not only as an educated scholar, but more importantly as an initiated Kamilaroi ceremonial leader and language speaker - just as with the Jews reflecting on Hitler and the Shoah - in colonisation I only see ... the Devil. 


\section{Burranba-li ngay guyungan-dhu ali-y (The fluidity of my own identity ...)}

... A Devil hidden in history books that continues to glorify the names of those responsible for the mass murder of my people. Men such as Christopher Columbus, James Cook, Cecil Rhodes and Oliver Cromwell. The United Nations lists about 17 million having died through slavery, and though I have not been able to find an actual number, to suggest a figure of 17 million when the truth is closer to somewhere between 60 to over 100 million killed, I see the work of, yes ... the Devil. Include disease, frontier wars, starvation and occupation and we are talking anywhere between 100 million to over 150 million, maybe even more, lives taken in an unspoken holocaust which only eats away at our consciousness, benefiting white fragility in denial of the truth ... When you consider the collective memory and genetic lineage that Aboriginal people maintain over generations, this is a mourning and grief that cannot be described or understood within the immediacy, entitlement or self-decadence driving the Western world. The misery, poverty and substance abuse witnessed in our communities on one hand is hard to endure, but to then have to witness the celebration and pride of those descendants responsible for killing our people, keeping their possessions, wealth, status and titles taken from stolen Aboriginal lands reaped during this time only contributes further to the trauma we carry. They glorify and continue to respect those they have lost in mourning and remembrance to their own while denying those whom they killed in building the wealth they enjoy today ... It's morally reprehensible and in writing this memorial to those we have lost I have at times been brought to anguish and despair. Left weeping at my keyboard in paying tribute to those fallen when history has let them down in forgetting them. I join other black writers throughout history, W.E.B. Du Bois, James Baldwin, Maya Angelou and orators such as Marcus Garvey, with no option as a parent of black children but to tell the truth and deconstruct history for the lies it represents - and my motivation is made simple ... Why ... because ... Black Lives Matter! 
What began as an enquiry by a young mind working on a school assignment became a right of passage from childhood to adolescence. As my son became more exposed to the truth over his teenage years, his peers remained in the dark, told to admire mass murderers and thieves like Cromwell, Rhodes, Columbus and Cook. Years after our conversation it was not until writing this passage that I realised not only are the deaths of black people erased from history, but whites recorded the massacre, deaths and sacrifice of their own in a form of remembrance in reaffirming their racial superiority. They commemorate their own in reverence with memorials remembering times and dates specific to individual names and periods, while at the same time not only denying people of colour their pain, but also taking no responsibility for the lives they have taken.

I'll give you some examples: I jumped on the Australian War Memorial website that completely excludes the sacrifices of Aboriginal people, with no mention whatsoever of those who lost their lives during the frontier wars defending their land against European invasion. The memorial is representative purely in regard to white settlement, starting with the colonial period, 1788-1901, documenting the marines who guarded the English settlements at Sydney Cove and Norfolk Island. The next memorial is the 1810 73rd Regiment of Footmen, whose roles were varied but included the suppression and dispersal of the Aboriginal population to make way for British settlement. That's right, the Australian War Memorial from its conception defines Europeans as Australian, with Aboriginal people only included within the Australian Memorial as the other, an enemy, a people to be subdued, colonised and invaded. It becomes a common thread, as early wars remembered over and over again are in conflict with Aboriginal people, not only within Australia but also internationally. The next documented remembrance is Australia's involvement in the Anglo-Māori wars in New Zealand between the 1840s and 1860s. The memorial states Australia's involvement resulted from 'the continuing expansion of European settlers onto Māori land and the colonial government's determination to crush native independence' (Australian War Memorial, 2017).

The memorial then pays tribute to those white Australians who lost their lives in the early 1880s after the British-backed Egyptian regime in the Sudan was threatened by an 'Indigenous' rebellion. Then there is the Boer War, in South Africa of 1899-1902, where the British used concentration camps against Boer women and children; and then the Boxer Rebellion of China in 1900-01 where the Chinese were fighting against forced imperialism and trade. These all pay homage to white Australians before and during federation, with the country only becoming an independent nation on 1 January 1901. There are no memorials or remembrance to any of the Aboriginal Australians, Māori, Sudanese and Chinese who lost their lives. In summing up Australia's attitude towards the systematic killing of Aboriginal lives, the Mayor of Hobart Sue Hickey said the following in relation to a proposed memorial in regard to the Tasmanian genocide. 
I didn't kill the Aborigines, and nor would I. It was a different era ... and it's not a guilt-ridden place ... Whatever happened 200 years ago is really, really sad, but lots of atrocities have happened.

(Hickey, cited in Shine \& Aird, 2016)

What we are witnessing is a culture of exclusion, not inclusion, as stated by Aboriginal actress Miranda Tapsell when she stated that as Aboriginal people we are just not allowed to 'feel Australian' (Noyes, 2015). We will never know for certain the amount of Australian Aboriginal people lost due to the frontier wars and the white European invasion. The documentation needed to determine an exact figure has been destroyed. What does exist are the stories of ongoing massacres of Aboriginal people happening over and over again in the historical archives of Australia and Great Britain. These are witnessed in diaries, letters, journals and memoirs of colonial and post-colonial officials, troops, police, farmers, men and women. Early newspapers also wrote detailed accounts of the frontier violence. 'Such stories are so often defined by a chilling, deeply disturbing candour, so detached are the killers from the humanity of their victims' (Daley, 2014). The evidence, though ignored, is overwhelming and then, like in Ireland, there are the rich oral histories of our own Aboriginal communities which recount massacre after massacre recorded in our traditional dances, art, ceremony and stories. I cannot state enough the trauma of these massacres carried from generation to generation by a people who believe in genetic memory and collective consciousness as the very lifeblood of their existence in connection with their ancestors.

Just as with interdisciplinary practice, environmental land management and interconnection between living things now becoming accepted within Western science after first being recorded by Aboriginal nations, a number of studies over the last 20 years are demonstrating that trauma too is being carried through from generation to generation. A leader in this field has also provided more argument towards the concept of autobiographical ethnicity as evidence-based research: Rachel Yehuda, PhD, Professor of Psychiatry and Neuroscience, is the Director of the Traumatic Stress Studies Division at the Mount Sinai School of Medicine. Professor Yehuda grew up in a strong observant Jewish family. An observant Jewish family defined as being involved in ritual practices and carrying out daily mitzvot (commandments). As a consequence Professor Yehuda was immersed throughout her childhood in Jewish culture and tradition, attending a Jewish day school and raised by her rabbi father. As part of her autobiographical ethnicity Professor Yehuda was exposed directly to many Holocaust survivors. It was as a direct result of this autobiographical ethnicity where Professor Yehuda first became motivated towards research that would help her understand better the intergenerational trauma she was witnessing (Yehuda, 2015). Her research has demonstrated that genetic changes stemming from this same trauma can be passed on to one's children, evidence that one person's life experience can affect following generations (Thomson, 2015). The research team analysed the 
genes of children, descendants of those who had experienced the Holocaust known to have increased likelihood of stress disorders, anxiety and trauma, against other Jewish families who were living outside of Europe during the war who did not experience the Holocaust first-hand.

'The gene changes in the children could only be attributed to Holocaust exposure in the parents', said Yehuda. This research is the clearest example in humans of the transmission of trauma to a child via what is called 'epigenetic inheritance' - the idea that environmental influences such as smoking, diet and stress can affect the genes of your children and possibly even grandchildren.

(Thomson, 2015)

Bohacek and Mansuy (2015) explain the importance of this research in understanding trans-generational trauma.

This mode of inheritance is crucial for medical genetics because it helps to explain the aetiology, expression and heritability of prevalent neuropsychiatric diseases such as depression, personality disorders, anxiety and autism.

(Bohacek \& Mansuy, 2015, p.641)

Such research demonstrates why we see so much suffering in Aboriginal and black communities around the world as trans-generational poverty and substance abuse is acted out within the collective trauma passed on from generation to generation. Everywhere Aboriginal people were invaded, where other people of colour were brought in as slaves, every Western settler colonial country in the world has created pockets of despair. What can only be described as corrals of human misery, where the refuse of society gather. No employment, education or hope, fuelled by alcohol, substance abuse and violence. The human waste and spillage in what is meant to be civilised societies, forgotten and living in wastelands until they become political leverage ... it's sickening. Such communities linked to studies 'where such mechanisms have been hypothesized to underpin vulnerability to symptoms in offspring of trauma survivors' (Yehuda et al., 2016, p.372), as descendants of genocide isolation is a consequence of collective trauma carried over generations. Parental trauma exposure is also associated with greater risk for post-traumatic stress disorder (PTSD) and mood and anxiety disorders in offspring (Yehuda et al., 1998). The trauma is so great that biological alterations associated with PTSD and/or other stress-related disorders have also been observed in offspring of trauma survivors who do not themselves report trauma exposure or psychiatric disorder (Yehuda et al., 2000). This means that for some, trauma is not evident in the survivors but instead their descendants. There are also animal studies that reaffirm trans-generational trauma in demonstrating stress exposure resulting from one generation to the next, and such mechanisms 
have also been believed to support research on humans that show vulnerability symptoms being passed down to the offspring of trauma survivors (Gapp et al., 2014).

As a Kamilaroi teenager growing up, I remember like yesterday my uncle, Reg Knox, first telling me of the Myall Creek massacre. I had noticed that many of the old people would often go quiet when talking about a regular journey for us in returning to traditional country back home from Brisbane, travelling through Toowoomba, Warwick to Inverell, which was the traditional route taken across the following Aboriginal nations: Jagera, Mununjali, Barrangum, Bundjalung, Gimbagnirr, when travelling to attend traditional ceremonies held at the Bunya Mountains. The Bunya ceremony was the focus of major gatherings for over 60 nations from south-east and central Queensland to north-east New South Wales. Held every three years, these were among the largest ceremonial gatherings in Australia. The Bunya festival occurred when the nuts of the bunya pine ripened, where initiation ceremonies and trade routes were established across the east coast. The ceremonies maintained practices in kinship marriage, law and heritage in sharing history connected through Burrambuurra (songlines ...) and Burruguu-ngayi-li wurruwi (Dreaming paths ...) dating back to creation.

I asked Uncle Reg why there was always a pause of silence when the old people discussed this journey back home. He asked if I had ever heard of Myall Creek ... I was suddenly hit with a sharp pain in my chest accompanied with an associated sadness; this was genetic memory. I started to cry but couldn't explain why. 'Close your eyes', he told me. His voice went quiet, almost a whisper, as he told me to listen ...

I want you to hear the children laughing and playing, in the water, he started to clap in a rhythm associated to ceremony and clap sticks. Can you hear them he asked me ...? I nodded yes and started to smile still with my eyes closed. He got steadily louder in both his clapping and voice, now picture the women preparing for the children to come home, the men are away at ceremony - just women and children playing. The clapping got louder with his voice now almost singing, the joy was unbelievable ... I had become immersed in happiness, could even hear the water splashing with kids playing and laughing. The women like the children all laughing and happy as they look over their lands, dinner now prepared, they call the children home ... the clapping slowly starts to become quieter and quieter as Uncle Reg chants, ah, ah ... ah, ah ... ah, ah ... ayyy ... nothing else is said, just the chants and clapping becoming slower and slower and quieter and quieter as suddenly the happiness and laughter is replaced with unbelievable sadness ... my heart ripped from my chest as I start to cry, feeling an unspeakable pain. The chants and clapping now so quiet you can hardly hear them, and suddenly nothing 
but silence ... an unspoken grief ... as quickly as they had come into my consciousness, my present memory, the families were now gone.

(Knox, 1983)

Uncle Reg just hugged me and we cried together - no dates or times, no actual numbers of dead, but I was there, I saw it, felt it, the women and children taken while the men were away and the sense of absolute grief when they returned to find their loved ones ... gone. The women, their mothers, wives, sisters and daughters along with their sons, all gone. I have never felt such pain. The Myall Creek massacre resides deep in the consciousness of every Kamilaroi, even today passed down through oral tradition, song and ceremony long before acknowledged within the pages of history written by white people. Not only through ceremony carried as a collective consciousness but as discussed above in current research, also carried in our very DNA. These were Kamilaroi women and children massacred while the men were away working on another station. They had become refugees on their own land, invited by one of the killers, Charles Kilmeister, to come to another station for their safety and protection from the gangs of marauding stockmen who were slaughtering Aboriginal survivors on sight (Tedeschi, 2014). Testimony was later given at trial by the station hut keeper, George Anderson, that one woman, and one young child, survived because the murderers considered them to be 'good looking'. During the initial panic, two young boys also managed to survive, escaping by hiding in the creek, breathing through reeds. They were brothers, Jimmy and John Munro, the grandfather and great-uncle of my mother's uncle Lyall Munro Snr, my grandmother's first cousin. My grandmother's father was George Saunders who also had two boys, Jack and Cecil Saunders, so close is this memory to my own family. After speaking with Uncle Lyall who gave me the names of my two direct family members who survived, I rang my sister Kim to tell her, but she already knew the boys' names and gave a heart-breaking account of what she had been told as a little girl.

There were around 30 women, children and elders who were tied and dragged to their deaths. Children and old people hacked to death one by one in a bloody slaughter where the killers lined up along guardrails of the stockyards with machetes, axes and saws used for cutting down massive trees ... they got off on making our people run as far as they could, cutting them to pieces, dismembering them, just close your eyes and imagine it as we were being forced to run through this slaughter line ... when I was told I rolled up into a foetal position and just cried, rocking back and forth sobbing for hours. This was our direct family - babies were beheaded, women raped as they were killed in front of their children and parents, young and old, brutally tortured and elders mutilated.

(Schloss, 2017) 
Uncle Lyall and documented history have now corroborated the horror of what my sister told me. It was only then that I understood why as a young boy when Uncle Reg first mentioned those words 'Myall Creek' the pain of sadness overcame me. Those slaughtered then had their bodies burnt in pits. Myall Creek station manager William Hobbs made the gruesome discovery shortly after returning from a business trip. He counted 28 victims, by conducting a gruesome tally of severed heads. Hobbs reported the incident to the Governor in Sydney, George Gipps, who ordered an investigation. Eleven of the 12 stockmen were arrested and charged with murder. Their trials began on 15 November 1838. All were represented by a top legal team provided by a consortium of landowners and pastoralists from the region. After deliberating for only 15 minutes, the jury found all 11 men not guilty. The verdict met with uncontrollable cheering in the courtroom (Munro, 2011). Attorney-General James Plunkett then requested and was granted another indictment.

The second trial, ten days later, accused only seven of the original ten men and focused on the killing of just one Aboriginal child. Eventually the jury found them guilty of the murder of the child. On 18 December 1838 the seven stockmen were hanged. For the first time in Australian history white men were punished for murder of Aboriginal people.

(Parbury, 1986, p.55)

There are many more massacre sites on my own Kamilaroi traditional homelands retained within the memory and grief of our collective ceremony and law ... buluwaal ngiyani muur-gi gi (lest we forget ...):

Little Waterloo, Biniguy, Slaughter House Creek, Jerry's Plains, Ourimbah Creek, Saratoga, Singleton Plains, Nurrarundi, Gurley Creek, Gravesend, Terri Hie Hie, Dirrabun Hawkesbury River, Moree, Moree mission, Yetman, Bogga mission road, North Star, Boomi, Inglewood, Tingha, Inverell, Gunnedah, Narrabri, Wee Waa, Tamworth, and Breeza plains (massacre sites retained in the oral history and memory of the Kamilaroi Aboriginal people of Australia).

The last widely accepted official state massacre of Aboriginal people by white Australians was at Coniston in the Northern Territory in 1928, 13 years after the invasion of Gallipoli in 1915. The invasion of Gallipoli took place on the Gallipoli peninsula in modern Turkey during the First World War. It would define the Anzac legend in Australia, describing its military relationship with New Zealand and Britain. According to Australian War Memorial principal historian and director of the centre for historical research at the National Museum of Australia in Canberra, Dr Peter Stanley (2008), Gallipoli encompasses 'bravery, ingenuity, endurance and the comradeship and become a symbol of Australia's national identity, achievement and existence'. 
Fervent nationalists can exult; pilgrims can mourn. All can ponder what made that group of Australians able to endure one of the greatest tests their nation has ever faced. This massive interest might be the result of careful marketing, by schools, publishers, the media or government agencies. But it seems that while the expression of interest might be directed, the consumption of the products seem to reflect the popular interest rather than manipulate it. Gallipoli, a minor, failed campaign (which cost less than a sixth of the Australian deaths on the Western Front) fulfils a need felt by many Australians to connect with or express their national identity.

(Stanley, 2008)

While Australia remembers with so much passion and pride those who fell at Gallipoli, 13 years later one of the main perpetrators of the Coniston Massacre of Aboriginal people was a Gallipoli veteran, George Murray, who would later boast in an interview about killing territorial Aboriginals (Daley, 2014). Even the death of a single unknown white soldier means more to Australians than the hundreds of thousands of Aboriginal people who died defending their land. I am talking about the memorial dedicated to 'the Unknown Australian Soldier' brought home at taxpayers' expense and now entombed in the Hall of Memory at the Australian War Memorial. The Unknown Soldier has his own tomb and was buried in a Tasmanian Blackwood coffin, on 11 November 1993, where there is placed a bayonet and a sprig of wattle. Soil from the Pozières battlefield in France where he was killed has been scattered across his tomb. The inscription on the tomb reads: 'An unknown Australian soldier killed in the war of 1914-1918.' At the head of the tomb is inscribed, 'Known unto God', and at the foot, 'He is all of them and he is one of us' (Australian War Memorial, 2017).

Just not Aboriginal. We get no such memorials or remembrance for our dead - where the estimated death toll for our people defending our lands against European invasion is significantly higher than non-Aboriginal Australians killed fighting on foreign lands. Eleanor Bourke (1998) estimated that in 1788 there were between 300,000 and 1 million Aboriginal people living in Australia prior to European invasion. D.J. Mulvaney and J.P. White (1987) proposed about 700,000 and N.G. Bultin (1993) estimated that there were between 1 and 1.5 million in 1788. Whatever the number, just over 100 years later during Australian federation in 1901, there were fewer than 100,000 Aboriginal people left (Kiernan, 2007). Bultin (1993) suggests the three major reasons behind such genocide were disease, the stealing and exploitation of natural resources, and murder, as discussed throughout the book. Many of the diseases, as stated earlier, were purposely introduced as biological warfare including smallpox, venereal diseases, and influenza, the strongest killers of people who had no immunity. Just as with Ireland, the English invaders and their Australian descendants seized native land and removed the Aboriginal eco-land management food production causing mass starvation, cutting 
families from their food resources, and finally there were committed grand genocidal massacres right up until Coniston in $1928 \ldots$ yes, Coniston was less than 100 years ago.

Buluwaal ngiyani muur-gi gi ... (lest we forget ...) that every continent these white Europeans invaded has had its resources drained as generation upon generation of these white families accumulated wealth as the Aboriginal people left behind were traumatised and forced to live in despair. There is not one colonised country in the world where the Aboriginal people as a whole share anywhere near the same quality of life, living standards and wealth as the non-Aboriginal descendants whose forefathers invaded them. Not only was the land destroyed by sheep and cattle through agriculture and agricultural farming, but Aboriginal people were forced into slavery, our men and women dehumanised and raped, and our children taken. Such is the depth of brutality associated with Australian and international history. I haven't even mentioned Australia's relationship with slavery. Referred to as 'blackbirding', a term taken from the Atlantic slave trade, Australians were practising slavery well into the 20th century and forced indentured labour much longer. So recent was its practice that archival footage exits on moving film (McDonald, 2015). Between 1842 and 1904, tens of thousands of people from the South Pacific islands were forced into working as slaves on the Queensland sugar plantations as yet another example of modern productivity built on the sweat and blood of slaves - now worth $\$ 2$ billion in exports as yet another example of industry that benefits the descendants of slave owners, while the great grandchildren of these slaves now live in poverty.

numerous Australian South Sea Islanders insist that their forebears were kidnapped or lured from their Island homes and committed to a life of slavery or quasi-slavery. My observation, from speaking at close quarters with many Australian South Sea Islanders, is that they are distressed by what they perceive to be academic denials of gross injustices ... living conditions on many plantations were seldom adequate, and the Islander populations suffered horrific death rates. In some years mortality among Queensland's Islander population was in excess of twelve per cent.

(Hayes, 2002, p.77)

Their victims were kidnapped, shackled, flogged, and many died of disease or maltreatment on the four-month trip over to Australia. Once here, they were sold to plantation owners. A strong male would cost the equivalent of between $\$ 5$ and $\$ 19$, while women, particularly Tahitians, fetched around $\$ 32$ (Perry, 1999). After Federation in 1901, unions banned Pacific Islanders from working on farms and many were later deported. Those who remained were denied the welfare and citizenship rights afforded to Aboriginals in the 1967 Referendum. It's a story that runs close to the heart of my own family. My children's great grandmother, Alice James, who only passed away in 2008, was a slave - that's right, my children, whom I write about extensively 
throughout the book. Their great grandmother, their mother's grandmother, was a slave. As a young girl, in addition to domestic chores, she had to collect water and even had a wooden yoke, a wooden bar used by oxen, as cattle tied around her neck, across the back of her shoulders to carry buckets of water back to the house. My children saw this and were told what it was. 'Nanna James' kept the yoke in her possession right up until she passed.

In addition, only last year, while visiting friends, my children, who are also of South Sea Islander descent, met James Warcon, a 50 year old who shared a story of his grandfather. James told my youngest boy and my daughter how his grandfather, while still on Pentecost Island (one of the 83 islands that make up the South Pacific nation of Vanuatu) first saw a white man. For those who are unfamiliar, Pentecost Island was made famous when David Attenborough, filming for the BBC in the 1950s, first brought back footage of the land-diving ritual practised by the Aboriginal people there. Between April and June every year, men in the southern part of the island jump from tall towers (around 20 to 30 metres high) with vines tied to their feet, in a ritual believed to ensure a good yam harvest. The ritual is also now used as an initiation ceremony from adolescence into manhood, making the island the spiritual birthplace of bungee jumping. James Warcon's grandfather never got to take his place in this initiation ceremony. The white man had a mirror glinting in the sun shining from his hand. James's grandfather remembers walking towards him in amazement before being knocked out cold. He came to in a slave ship bound in chains on his way to Australia, never to return to the island. It is a story along with that of their great grandmother that reverberates through the deep inner consciousness of my children, just as the story of the Myall Creek massacre did for me at the same age.

Between 1860 and 1970, Australia effectively had state-sanctioned slavery of Aboriginal people (Simmonds, 2015). Historians Dr Rosalind Kidd and Dr Thalia Anthony have documented how Aboriginal Australians of all ages were forcibly sent to work on sheep and cattle properties across Australia under government schemes that were supposedly 'designed to protect them' (Kidd, 2006, p.111). Laws in Western Australia allowed Aboriginal children to be sent from the age of 12. The conditions were often horrific: 16-hour days, floggings and forced removal from families. Deconstructing the Aboriginal indentured labour force has once again divided Australian academics between the left and the right. It has produced a 'free versus force' or 'victim versus agent' debate that only highlights again 'white privilege', while for the Aboriginal people who suffered there is no doubt either way ... it was slavery.

The 'unfree' school, led by Raymond Evans in the 1970s, views the brutality on the early cattle stations as a form of total control akin to slavery. Evans draws attention to 'striking parallels across time and space between the condition of the slave and the unfree Aboriginal worker'.

(Evans, 1984, p.203, in Anthony, 2004, pp.118-119) 
Aboriginal workers were either unpaid or had costs paid for food and accommodation despite lack of nutrition and poor living conditions. State governments assured workers that their wages were placed in a government trust, but most never saw a cent. 'Aboriginal people have been trying to recuperate these stolen wages for years unsuccessfully with not one claim in Australia against government upheld' (Kidd, 2006, p.45). From the 1870s to the turn of the century, Aboriginals, Malays, Timorese and Micronesians were captured and sold as slave labour in the pearling industry on the far north-west coast of Australia. Historian K. Forrest estimates that around 1,000 Asians were captured and sold into slavery. Aboriginals were rounded up from pastoral stations and, according to missionary and court reports from the time, sold for around five pounds (Gribble, 1887). Pregnant Aboriginal women were particularly prized because their lungs were believed to have greater air capacity in diving for pearls during pregnancy. The average life expectancy of a slave in the pearling industry was painfully short. In the book How the West Was Lost (1982), historian Don McLeod writes how sickness was rife, colds and influenza typically led to pneumonia and premature death, where pearlers were alleged to have boasted that so long as they could keep their divers alive for three months, they could make a profit on the investment.

A recent University College London study that traces the legacies of British slave ownership has shown that Australia was largely built from slave money. Following the abolition of slavery, British slave owners received compensation from the British government for the loss of their 'property' - a staggering 40 per cent of the Treasury's spending budget, which in today's terms, calculated as wage values, equates to around £16.5 billion (Manning, 2013).

The previously unseen records show exactly who received what in payouts from the Government when slave ownership was abolished by Britain much to the potential embarrassment of their descendants. Dr Nick Draper from University College London, who has studied the compensation papers, says as many as one-fifth of wealthy Victorian Britons derived all or part of their fortunes from the slave economy.

(Manning, 2013)

The research has shown for the first time just how significant the investment from this compensation was by families who outlaid money in ventures building the foundations of a prosperous Australian settler colony. In buying enormous properties of land as well as becoming directors of banks, museums and libraries. They built churches, became governors, such as in the case of Governor Broome who influenced greatly debate for the slavery of Aboriginal people and Pacific Islanders (Draper, 2017). Australia was a nation forged and paid for by white slave owners. They are the ones who contributed significantly to the Australian consciousness that gave birth to the white Australia policy; they maintained the lie of terra nullius, that Australia was an 
empty, barren land for over 200 years of occupation; and they maintained the great Australian silence.

In international law, 'terra nullius' describes territory that nobody owns, empty barren land allowing the first nation to discover it to claim it as their own. The British refused to acknowledge the prior rights of Aboriginal Australians despite written evidence and observation that Australia was inhabited. The decision to establish the settler colony based on terra nullius was one of the greatest forms of cultural genocide, deception and fraud known to any civilisation. This stayed Australian law until 3 June 1992, when six of the seven High Court judges upheld the claim by the Meriam people of the Torres Strait Islands under what has been called the Mabo decision, that the lands of this continent were not terra nullius or 'land belonging to no one' when European settlement occurred. The High Court recognised the fact that Aboriginal peoples had lived in Australia for thousands of years and enjoyed rights to their land according to their own laws and customs. This was less than 30 years ago. Can you just imagine sitting in a class at school, as an Aboriginal child, being told you never existed, you didn't belong, you had no history and were invisible. It's why Australia makes me sick, that Australians maintained this lie having dispossessed us from our own lands, and even today they just kind of move on from the Mabo decision as if it was nothing, oh, yeah, sorry .... and then argue there was no genocide, no invasion and no Stolen Generation. And remember, we are talking here about recognising we were here before they arrived, and they still just stare at you with blank faces looking right through you and then want to discuss abuse, domestic violence and substance abuse on the third-world communities they created. The Mabo decision had nothing to do with social justice, sensitivity, a change of heart, or enlightenment; it was forced on them through the High Court, as a response in reversing the lie of the previous 204 years, and in doing so, finally brought Australian law into line with common law as developed around the world including the United States, Canada and New Zealand.

This chapter was meant to be a transition into healing. The beginning of a shift in my writing that captures the resilience and rebirth of my internal holy place, cast as survival in overcoming the hardships of living in Australia as Aboriginal in the year $2017 \ldots$ but in capturing the atrocities of the past spilling over to my contemporary identity, so great are they in numbers that I only now mention terra nullius, makes me realise how symbolic my reality really is. When you rise up from this despair you disrupt this pattern, you give the opportunity to break it down and this gives you hope. It is fitting, then, that we begin this shift in writing exposing not only the lies and deception of terra nullius, but more important just how recent this lie was, remembering as referenced earlier from Barack Obama: 'Racism, we are not cured of it ... Societies don't overnight completely erase everything that happened 200-300 years prior' (Obama, 2015). Well, the Mabo decision was only 25 years ago ... this history leaves a gaping wound in the soul of our civilisation. Remember, I write this to you as a black man in mourning for not only my 
ancestors but also my great grandchildren. As a Kamilaroi First Nation Australian Aboriginal, my history of colonisation and oppression is firmly connected with that of not only my Aboriginal brothers and sisters but also those of black African American ancestry in the United States and other people of colour around the world. Colonisation has resulted in the marginalisation of our history while asserting the notion of white European superiority. The result is that the wisdom and traditions of our heritage have been debased by a Western value system constructed on a platform of organised violence, hostility and brutality against black people across the world. But let me be very clear, this is not a book about history, but instead revealing the seeds of hate that manifest in the world I live in today. I am not writing about history but instead documenting the origins behind recent events in the United States, including the towns of Ferguson, Missouri, Sanford and Minnesota, the list goes on ... where our people were killed by police. In Australia we have our people being killed at the same time in Redfern, South Hedland, Kalgoorlie, and East Perth. Only two years ago in 2015 then British Prime Minister David Cameron, a direct descendant of those slave owners who took massive compensation after its abolition (Manning, 2013), while in Jamaica refused to even enter into discussions on reparations for slavery and the trauma affecting the descendants of these slaves today. What he did do, though, was pledge to build a $£ 25$ million prison in Jamaica to relocate over 300 prisoners living in Britain, highlighting once again just how distant the West has come from accepting its obligations to humanity today and in the past.

In Australia, black people are under constant attack in the remote communities to which they have been relegated within a social and economic apartheid. While living in these third-world communities our water has been cut off and our homes destroyed in an attempt to once again forcibly relocate us to make way for mining. We suffer the highest suicide and incarceration rates in the world. As a black man, my heart is wailing against the ongoing hostilities our people continue to face worldwide as the violence of our past becomes embedded within the present. I was born at a time when my people were not allowed to vote, were still living in missions with our children being taken from their parents in a cultural genocide known as the 'Stolen Generation'. I am now living in a time when my people are still living in missions and our children are still being taken from their parents in having to live through another 'Stolen Generation'. I was born in 1968, the same year Wilt Chamberlain became the first NBA player to score 25,000 points, Tommie Smith and John Carlos gave the black power salutes during the Olympic Games and the year Martin Luther King Jnr was assassinated in Memphis. Today, less than 50 years later, the incarceration rates of black people in Western countries are higher than they were then ... where still the percentage of home ownership, steady employment and educational outcomes remain much higher in white communities than for my people. 


\section{Burranba-li ngay guyungan-dhu ali-y}

So yes, we need an international debate on reparations to answer why white communities have continued to gain in wealth and position over generations, while our black communities have become steeped in trans-generational poverty, substance abuse and violence. Just how many trillions of dollars did the Commonwealth and the rest of the Western world make as a direct result of slavery and in raping the natural resources of Aboriginal peoples across the world? The mind boggles ... Not to mention the trauma and pain collected by our people who in reality built the empire yet have been left with crumbs from white European tables. As Marcus Garvey said all those years ago, long before Bob Marley ever turned it into song ... 'Emancipate yourself from mental slavery'. Intellectual property has become the new 'agenda of colonisation' as our classrooms only pay attention to Western forms of teaching practice and ignore black and Aboriginal oral traditions of storytelling and shared history. This lack of partnership and understanding is what is blocking black culture and Aboriginal knowledge production as we continue the binary of the oppressor and the oppressed; this means a lack of deconstruction or even acknowledgment of this binary, and what or whom it serves. The truth of your history, cultural maintenance and retention of genealogy is the most significant weapon we as black and Aboriginal people have in this cultural and racist war. Black History Month is only one month out of the year and Aboriginal Studies stands alone and is moved sideways within humanities departments rather than being seen as integral to Western development and civilisation. It is time we let our children know the truth ... and to know the truth means we have to go back to the beginning where the lies begin, claiming our history in the foundations of civilisation, not out of Europe but Australia and out of Africa. We can't wait for the white people to teach our children the truth; we have to tell our children the truth. Tell them it was really our people who brought civilisation to the Ancient Greeks, black Africans from the Nile Valley called the Phoenicians. It was these black Phoenicians who introduced complex mathematics, cultivation, farming and forms of intellectual trade, not referenced in classrooms but in the autobiographical ethnicity of storytelling shared by Aboriginal and black people around the world. We have to tell our children how and why in Australia the education system is so based on a Eurocentric paradigm that devalues our own black cultural heritage, squeezing the breath out of our identity through disengagement built on the lies of terra nullius only broken because they were forced to listen in a High Court decision only some 25 years ago that we were here before the coming of the white man. Evidence shows that low educational outcomes for black children are associated with a lack of social inclusion and also intergenerational poverty that results through this ongoing failure in white schools. We survived attempted genocide, slavery and assimilation. How on earth can we not pass a written test in a classroom? ... Because we never contributed towards or wrote the test paper - that's why. The Aboriginal 80,000-year occupation of Australia and its pre-history prior to European occupation is all but ignored, as is African black history prior to 
slavery across the Western world. And in return we are now experiencing being beaten down and killed in the street, as Black Lives Matter in the United States and the torture and abuse of our Aboriginal children in correctional centres in Australia demonstrate the same acts of violence across other parts of the world - only serving to remind us who has the power on the streets, in the judicial systems, and in the classrooms of America, across the world, and in Australia.

It's brutal, it's historic and it's barbaric politics played out in the interface of black and white interaction, a long way from the safety of boardrooms and corporations that propagate white supremacy in our media, our schools, our political systems and our learned history. Only in calling on ancestral memories will our stories counter oppression in finding the truth at every interface between black and white. This has to happen locally, nationally and internationally through globally shared storytelling as a route to survival for black peoples against violence and aggression we are witnessing worldwide. We can never forget that the West won this control not through the superiority of its ideas, values or religion, but instead through organised violence, hostility and brutality. Westerners often forget this ... Aboriginal peoples never do ... and black people cannot afford to. 


\section{Wiringin-dhiiral (An Indigenous academy ...)}

Western governments, rather than discuss reparations and healing for the damage they have done, instead lay blame on bad management and nepotism within our black communities as the cause for poverty. Part of their strategy is in declaring traditional Aboriginal cultures as not viable within a $21 \mathrm{st}$ century, disguising white supremacy and racism under the banner of neoliberalism. All the while maintaining a dependency on mining fossil fuels contained within sacred lands as natural resources stolen from Aboriginal people, continuing our devastation, while making yet another generation of white people rich and untouchable. It is surreal walking on traditional homelands in Australia, on remote communities barren with no infrastructure, shanty towns in third-world poverty ... some even with little to no water surrounded by multi-million-dollar cattle ranches and mining deposits worth not millions but billions of dollars. This book has been written at times in anger, frustration and in wanting to prevent any sense of hopelessness. I can write and publish, lecture and discuss every day of the week about cultural genocide, personally living through another Stolen Generation, my hands tied as a Native Title Owner as mining companies continue to rape my sacred lands, a representative of a people still suffering deaths in custody, the highest youth suicide rates in the world, but in writing this book I have taken another step in empowering not only myself but the many vulnerable and voiceless I come into contact with almost daily in my communities. Every day we fight against racial discrimination and in wanting to improve both our civil and human rights, but with a growth in neoliberalism; where once we were an absent silence within mainstream media we now suffer open contempt and judgement labelled as a 'victim brigade unable to move on from the past and responsible for our own demise' (Dillon, 2017). In decolonising the truth and documenting the real history of the world, as an Aboriginal person I am left exhausted and traumatised upon my reflection in trying to find hope. I have always struggled to find an answer, not so much why such horror occurred - I understand history - but my problem is in understanding why we have continued to cover it up generation after generation as the descendants of a predatory culture continue to benefit, and more recently degrade and attack those most helpless. As if your wealth, security and position were not enough, 
you now have to humiliate us as well. There is not only something very wrong with the world, but more importantly there is something very wrong with those running it.

Strangely enough I found an answer, at least for now, as last night my son, who is mentioned throughout the text, now 16, and I watched a movie together - The Big Short, a 2015 American comedy-drama directed by Adam McKay and written by both McKay and Charles Randolph, and based on the 2010 book The Big Short: Inside the Doomsday Machine by Michael Lewis. The film adaption, as with the book, is about the financial crisis of 2007-08, which was triggered by the United States' housing bubble and affected millions of Americans, who lost their homes, their jobs and life savings. The film stars Christian Bale, Steve Carell, Ryan Gosling, Brad Pitt, Melissa Leo, Hamish Linklater, John Magaro, Rafe Spall, Jeremy Strong, Finn Wittrock and Marisa Tomei, and in its unconventional narrative techniques utilises yet another form of autobiographical ethnicity to explain unethical financial strategies hidden as complexities which led to the financial crash. Due to the need for financial industry jargon to fully understand what is going on, the filmmakers utilise known celebrities that the audience can immediately relate to in once again breaking down the fourth wall to explain what was going on. Celebrities outside of the film's narrative who appear include Margot Robbie, Anthony Bourdain, Selena Gomez and Richard Thaler. They are used primarily not as characters within the film but to instead explain directly to the audience concepts such as subprime mortgages and collateralised debt obligations as a meta-reference broken down in laymen's terms to better understand the film. In addition to these celebrities breaking the fourth wall there are also characters essential to the central narrative within the story who also directly address the audience. This is done most frequently by Ryan Gosling, who serves as the narrator throughout the film as yet another example of autobiographical ethnicity, sharing his life story in relation to the events happening around him at the time. The film not only serves as an example of autobiographical ethnicity, it also answers a much deeper question asked throughout this book. It is true that an astonishing number of people, including the chairman of the Federal Reserve himself, continued to ignore the housing market bubble, even denying it was happening, allowing one of the greatest financial crashes to occur rather than accept the truth. Such denial or 'post-truth' is a common theme throughout my own narrative within this text, which highlights across history where authorities have denied rights, truth and justice to Aboriginal people throughout history. The Big Short shows that having got away with it for so long, those in power are now more than capable of turning such deceit on their own kind where modern slavery, rather than being kept in chains, is enforced through debt.

So what is happening? The answer is complex. Arguably, what we are witnessing is a toxic combination of policy blunders on austerity, war and globalisation coupled with a new hybrid media and political system 
dominated by reality TV. Social media and filter bubbles. Combined with what has been dubbed 'post-truth politics': where appeals to emotion are dominant and factual rebuttals or fact checks are ignored on the basis they are mere assertions.

(Suiter, 2016, p.25)

The book The Big Short: Inside the Doomsday Machine was acknowledged in its exposing of greed against those most vulnerable, receiving the 2011 Robert F. Kennedy Center for Justice and Human Rights Book Award. The book describes how several of the main players created a credit default swap market after forecasting the crash which was about to happen, making millions off ordinary Americans who suffered financial ruin.

The Big Short has a broader focus than Margin Call and a more explicitly political perspective. Historically speaking, though, its approach is equally valid: its focus is on the Wall Street personalities involved, the mind-blowing levels of denial and cover up among regulators, ratings agencies and banks, and ultimately the consequences.

(von Tunzelmann, 2016)

The final voice-over narrative at the end of the film says it all, much better than I can write here and with much more exposure than I can ever hope to gain personally, revealing the big banks, instead of facing consequences for the millions of lives they ruined, were given a financial bailout by government:

The banks took the money the American people gave them and used it to pay themselves huge bonuses and lobbied Congress to kill big reform ... and then they blamed immigrants and poor people and this time even teachers. And when all was said and done only one single banker went to jail, this poor shmuck, Kareem Serageldin from Credit Suisse. He hid a few billion in mortgage bonds losses, something most of the big banks did on a good day during the crisis.

(Voice-over, The Big Short, Gardner et al., 2015)

At the end of the film my son turned and asked me ...

How is it that nobody is willing to take responsibility and this was allowed to happen? So many people lost their jobs, their homes and only the poor were punished, it just happens over and over again and it's like nobody cares. It's like once people realise something's not working, rather than be honest they just tell more lies, to cover up more lies, knowing the whole time it will crash, but no one cares ...

(Waters, 2017c) 
And that's when I realised that this film just answered the dilemma I had asked of myself in writing this book, in fact my entire life. I wished it was something deeper, something that had real meaning, true significance - even an ancient ritual curse, a prophecy, anything but greed and power ... but at the end of the day that's what it is ... greed and power catering to ego. All I could do was turn and say to my son ... 'It's because no one appears interested in the truth ... only what they have and the foundations of what makes them secure, even if it's based on lies'. It was then I realised acknowledgment of post-truth as part of an overarching denial embedded deep within the framework of Western consciousness, which dates back, whether or not they understand it, to colonisation. The basic principle is that of power, class division and racism. The right to extract every resource while preventing education and agency from those you benefit from in profiteering from their misery is taught from one generation to another. It is a system evolved and maintained throughout history ... taught in white schools and celebrated on days which remain significant to one group while offending others in having one group feel superior in reaffirming their position while denying the other. Australia celebrates Australia Day on 26 January as the date of European arrival, an arrival that brought disease, genocide and trauma, and decimated our people. There are some local councils that have started a movement, out of respect to Aboriginal people, and have chosen not to join the rest of the country in celebrating on this date. This represents a changing tide in sensitivity and enlightenment. The last 30 years in the United States have seen Columbus Day discussed more for its notoriety than its celebration as this country revisits its past. Christopher Columbus not only invaded the local Arawak people with complete devastation but also established the transatlantic slave trade. It was made a federal holiday in 1937, Australia Day in 1935, so these are not longstanding days of celebration marking the dawn of settler colonies as many would have you believe, instead becoming only recent dates of significance in consideration of covenants maintained, cultivated and occupied for tens of thousands of years. Many US states, including Texas and California, no longer officially mark Columbus Day. Others, like South Dakota and Vermont, celebrate an indigenous person's day instead. In Australia, Yarra and Darebin Councils have distanced themselves from Australia Day celebrations and many more are in discussions to join them, with the Northern Territory chief minister Michael Gunner also calling for changes to Australia Day to highlight 'the Aboriginal contribution to our national identity' and 'acknowledge the lasting trauma of Indigenous dispossession' (Robertson, 2017a). What is happening is a groundswell coming from events associated with Charlottesville and earlier events of violence and hatred where white supremacist groups have unwittingly drawn attention to the historical racism and history behind many icons of celebration within and throughout Western civilisation.

The current battle actually goes back to a mass shooting in 2015, when self-described white supremacist Dylann Roof shot and killed nine people 
in a predominantly black church in Charleston, South Carolina. Roof drew a lot of attention for posing with the Confederate flag in images that came out after the shooting - and that helped spur a fight within South Carolina about whether it should take down a Confederate flag that had flown at the state capitol for years. The state eventually agreed to officially take down the flag.

(Lopez, 2017a)

In 2017, such symbols, whether dates, statues or flags connected to horrific crimes of inhumanity, slavery, invasion and genocide, should not be used to define any liberal, democratic, civilised or multicultural society. There is an inevitability within Australia that it will eventually have to move its national day of celebration from 26 January. The very fact we are having such a debate in 2017 only demonstrates the audacity of those showing their hypocrisy and vulnerability at the mere suggestion that these relics of the past be removed. This is despite spending the last 500 years attempting to erase everyone else's history on the planet ... whether or not they are conscious of the fact these people against changing dates of significance, removing statues and flags which represent this horror, are only revealing themselves as modern-day plantation slave masters over the oppressed.

The arc of our history has been a steady, albeit slow progression towards inclusiveness and tolerance. Something in which we should take immense pride. From women being allowed to vote, to non-whites being allowed to emigrate here, to gay relationships being legalised. We move forward together and with every passing year our collective history becomes richer.

(Bendall, 2017)

I then write this book as a form of decolonisation, which for me personally remains about repatriation of Aboriginal land and life in opposition to and revealing the hierarchal structures that have censored and controlled Aboriginal and black societies across the globe. I want to make it clear that I do not see decolonisation in any other way, despite what many theorists suggest ... it is not a metaphor for other things. As the academy again tries to capture a grassroots movement and take ownership in suggesting the use of decolonisation as a term of reference by the people on the ground, protesters on the streets, restricts its true meaning. The idea that decolonisation as a term separate to that of the academy and used outside of a university framework is problematic (Tuck \& Yang, 2012) is nonsense and elitist, and those academics, both Aboriginal and non-Aboriginal, who articulate challenges of solidarity across power and difference to metaphor (Mignolo, 2012) are creating a deadly precedent. They are only supporting institutions that continue to position one group as more powerful, as we and those who protest on the ground are seen as different, in deficit, and weaker (Mander et al., 2011). 
The truth is that awareness is not coming from the academies of Western learning; these are voices being raised from black and Aboriginal groups across the world. Here within our own black and Aboriginal communities we are setting forth a new set of purposes for schooling and education in direct opposition to current 'Indigenous' educational models that previously only maintained the binary of colonisation (Lomawaima \& McCarty, 2006). This is because no matter how you position yourself within them, white settler communities are still positioned as more legitimate, appropriate, powerful, and knowledgeable than black and Aboriginal peoples. The greed and power from institutions that feed on the most vulnerable are there for all to see, they expose themselves. All we are to do is open our eyes and our ears to the truth. Every police officer who is acquitted for the murder of our people, every third-world country invaded, every mining lease granted does not set the guilty free - it only confirms the deep structural problems still embedded in racism, hatred and fear. These are actions, just like the white supremacists who gathered in Charlottesville, that rather than set them free, confirm their guilt in a society built on post-truths, fragility and denial, rather than inclusive practice, humanity and truth.

For decolonisation to occur it must start at the very institutions that maintain and continue the deficit model of Aboriginal knowledges - as at present ... Aboriginal people in wanting to make sense of the privilege offered in university settings, are forced to share common narratives within the privileged binary in order to interpret and transfer such meaning within their own lives. This creates personal agency that benefits the individual but can distance them from the community they first came from. Decolonisation is therefore becoming aware that not only is this happening, but also in then making a conscious decision to maintain connection and values to those of the Aboriginal community over and above those of the university. This is not nearly as simple as it sounds, as those who prioritise their community can quickly become excluded or rendered uncomfortable from the competing values they represent. In other words everything is fine as long as we don't mention Black Lives Matter, Aboriginal people living in third-world conditions, white privilege, or the removal of statues and changing significant dates, which brings alienation as an active form of neo-colonialism. Both individual and collective identities are then shaped by multiple and competing discourses over long periods of time. Thus far, there has been little acknowledgement in the academic literature of those 'Indigenous' scholars who have chosen personal agency and social mobility over and above the needs of their community. Those Aboriginal and black people who instead contribute to post-truth as austerity economical rationalisation, used as pawns by Western media, politics and industry, wheeled out to point blame at their own communities. Smallwood (2015) has referred to these ultra-conservative Aboriginal people as those who have become colonised in order to be accepted or passed as common sense in mainstream Australia. Smallwood highlights that for some Aboriginal intellectuals traditional Aboriginal cultural maintenance and 
practice has become less important, where the relationship prioritising their individual identity over and above their cultural identity has allowed for an acceptable liberal emerging Aboriginal middle class, and in some cases a barely discernible united Aboriginal image. In justifying this modification of their conservative politics, these institutionalised self-appointed Aboriginal leaders argue that their internalisation of the Aboriginal experience, message and worldview over the years has rendered the need for economic development, reciprocity and a break away from welfare dependence as more important than maintaining the uniqueness of Aboriginal culture. It is a position that has allowed some Indigenous people - Marcia Langton, Noel Pearson and Ken Wyatt - to become accepted within mainstream politics, due to their support of austerity and neoliberalism as integral strategies in the guise of 'leading Aboriginal people out of disadvantage'. Aboriginal storytelling as autobiographical ethnicity has the capacity to unmask such politics and at the same time disrupt the identity of failure where privileged institutions label our Aboriginal identity as dysfunctional, not compatible with 21 st-century industry. In finding our unique Aboriginal voice to counter these arguments, we must exclude not only privileged institutions but also white authorship from examining the relationship between the struggle for our human rights and cultural practices as part of the decolonisation process. To create strategy where through Aboriginal authorship we ourselves independently build historical awareness of the legacy of our own heritage currently denied as an ongoing act of neo-colonialism - rather than taking on the politics of our oppressor in order to become accepted.

This is to be achieved in recalling the central role of intergenerational teaching practices as the foundation of our childhood subjectivities. In doing so we first disrupt and then remove the false constructions of our life story enacted by hegemonic 'white' educational institutions and non-Aboriginal authorship. It is here that I see autobiographical ethnicity as a way forward. Decolonisation disrupts and radicalises the 'myth' of post-colonialism perpetrated within production houses of learning, whether universities or classrooms across the world. What we are seeing is a strategic division of black races around the world preventing unity and solidarity within the labelling of 'Indigenous' over and above Aboriginal - in that many are born from the country we live in ... but we are not all Aboriginal. The Indigenous academy by its very creation within a racist institution allows non-Aboriginal academics to retain the binary relationship of authority and status established as the 'coloniser' and the 'colonised' and/or 'non-Indigenous' and 'Indigenous' (Moreton-Robinson, 2003b, p.73). The binary as representative of the dominant white culture is everywhere - so much so that the preservation of traditional Aboriginal culture feels like a useless task (Kincheloe \& Steinberg, 1997). The trap of such a binary relationship of hierarchy is that once taken on it becomes almost impossible to reverse, and only serves to reinforce the power relationship between Indigenous and non-Indigenous peoples. 
It is considered a sign of success when the Western world, through one of its institutions, pauses even momentarily to consider an alternative possibility. Indigenous research actively seeks to extend that momentary pause into genuine engagement with Indigenous communities and alternative ways of seeking to live with and in the world.

(Tuhiwai Smith, 2005, p.104)

Aboriginal people have become completely removed from the debate. It is a phenomenon cited, though I believe unintentionally, by Noongar Aboriginal writer Kim Scott in a published interview for the book, Giving this Country a Memory: Contemporary Aboriginal Voices of Australia:

To have non-indigenous people interested in Noongars, and in what we are speaking about concerning our heritage, is a really powerful position to be in. We very rarely get those situations where it's indigenous people giving and sharing, and being valued for doing so.

(Scott quoted in Brewster, 2016, p.15)

In short, the book in which Scott appears is a research manuscript written as a number of critical essays and accompanying interviews with Aboriginal writers. The book is compiled and edited by a white Australian, Anne Brewster. Brewster tries to dodge a bullet upfront regarding her own white privilege, claiming her awareness of the 'possessive investment of the white/ European subject', but white privilege is much bigger than any one statement, no matter how aware the writer may be. As a result, Kim Scott's comment is not only minimalist, it is reductionist. What is actually needed to critique such a statement is knowledge of the culture(s) from which the works derived. Only then can one provide an informed response, which cannot come from a non-Aboriginal interviewer, writer or editor in any capacity. Scott goes on to claim, 'there's not many of us doing it' (Scott quoted in Brewster, 2016, p.15), which is both indulgent and self-serving, and is not a true reflection of Kim Scott the man. I know Kim personally and he is as humble as he is brilliant, so someone or something has become lost in translation. The simple truth is we spend our entire lives as Aboriginal people, 'giving and sharing' and 'educating' white people.

Aboriginal storytelling has been around tens of thousands of years - far longer than Western culture. Aboriginal writing, storytelling, pedagogy within all its forms of knowledge production needs to be seen as standing equal, parallel and as an alternative to Western knowledge production, not as a subsection or as an elective within a humanities or sociology degree, or as a form of contemporary literature. I need to state clearly that I am questioning a person's right to education, social mobility and agency. I do not come from a deficit model of my Aboriginality and I have benefited from my education, no doubt. What I am discussing is awareness in negotiating the binary to retain a uniquely Aboriginal voice. I do not accept poverty, incarceration and violence 


\section{Wiringin-dhiiral}

along with substance abuse as integral to my Aboriginal worldview. Instead, as stated previously, my inherent epistemology is clear and never questioned: I am/remain Kamilaroi, my Yanguru (Moiety as genetic memory) is ancient and my Yarudhagaa (Totem as genealogy) is/remains Kubbaanjhaan (Lineage/Kinship) connecting me to my Burruguu-ngayi-li (Dreaming) as defined through Gawuban Gunigal (the waterways, valleys and songlines throughout Australia). Now let me make this clear - when we introduce ourselves through such cultural authority, there is nothing a non-Indigenous, nonAboriginal, non-black Australian, Indigenous or white scholar can contribute towards Aboriginal knowledge production, literature, critical race theory and/ or whiteness studies beyond what we have stated we are aware and willing to contribute ourselves. I have lost count how many times, not just myself but other esteemed Aboriginal people, after such an introduction we are immediately silenced by a white person, either with or without a degree, talking over them. It happens all the time ... instead, when a white person is confronted with such cultural capital they should just get out of the way, pass over the pen, laptop, stand aside within the forum, whatever, and allow us to write, speak and represent ourselves as demonstrated by the authenticity in the authoritative statement of self. This is autobiographical ethnicity in practice.

Once a white Australian makes any such statement in response to such an introduction, the text, statement or narrative is no longer uniquely Aboriginal, as demonstrated by Moreton-Robinson (2004, p.88), who makes it very clear that any definition of what constitutes an 'Indigenous voice' as part of 'Indigenous Studies' as generated by non-Indigenous academics will always be tainted through an institutional bias:

(t)o recognise that whiteness has shaped knowledge production means that academia would have to accept that the dominant regime of knowledge is culturally and racially biased, socially situated and partial. Such recognition would not only challenge the universalist humanist claims to possess impartial knowledge of the Indigenous other, it would also facilitate recognition of the subjects of other humanisms to whom whiteness has never been invisible or unknown.

(Moreton-Robinson, 2004, p.88)

Now, of course, I am aware that such a position has been deconstructed as reverse racism, that for some there is a claim that people can 'transcend' culture(s), but make no mistake, for white privilege, 'cross cultural' or the ability to transcend culture(s) is nothing more than a stamp of white approval, though much more elevated and polite than words such as 'accepted' or 'assimilated'. It again denies authenticity, as if somehow the white commentary can have empathy, or the black writer, entertainer, athlete or speaker is in some way a credit, in representing their race. Cross-cultural is also used as a way to say that blackness, or Indigenous in contrast with whiteness, is somehow limiting as opposed to Aboriginal, which stands alone. 
Blackness is that small subculture outside the white mainstream, and to find success in that mainstream, or engage in discussion with white people is, as stated by Kim Scott (Scott quoted in Brewster, 2016, p.15), seen as an achievement, which becomes a constant narrative throughout non-Aboriginal or non-black writing as part of critical race theory. Unless you have demonstrated support for our resistance, together with an established critique of our oppression, and you have made an active contribution towards our healing in regard to the cause and effect of trans-generational trauma of our people, then do not make suggestions or cite statistics to those who do - as they are dealing with our realities on a daily basis. Publications and the extraordinary numbers of non-Aboriginal white academics who build entire careers within Australia and internationally on cultural appropriation and the stealing of our intellectual property, are only contributing further to neo-colonialism in academic practice as modern-day slave plantation owners, where rather than dealing in flesh they are trading in black minds, intellect and our lived experience - and it has to stop.

The problem that always arises with this particular way of operating is that, because you are not interacting with people based upon who they really are, but instead are relating to them according to your own limited 'understanding' of them, consequences will result from this interaction that by necessity will result in injustices for those who are unable to operate in the world in a manner consistent with who they are. Such injustices also, by necessity, lead to interactions between the representor and the represented that are fraught with conflict.

(Chalmers, 2005 p.162)

As stated by Linda Tuhiwai Smith over 16 years ago in her landmark text, Decolonizing Methodologies: Research and Indigenous Peoples,

When Indigenous people become the researchers and not merely the researched, the activity of the research is transformed. Questions are framed differently, priorities are ranked differently, problems are defined differently, and people participate in different terms.

(Tuhiwai Smith, 1999, p.193)

George Lipsitz's 2006 publication, The Possessive Investment in Whiteness: How White People Profit from Identity Politics, goes beyond not only Indigenous writing but makes the same claim also for people of colour. Lipsitz takes us back to James Baldwin, when he states, 'there is no place for white people anymore citing Black writing within any capacity ...'

Blacks are often confronted in American life, with such devastating examples of the white descent from dignity; devastating not only because of the enormity of white pretentions, but because this swift and graceless 
descent would seem to indicate that white people have no principles whatever ...

(Baldwin, 1963, in Lipsitz, 2006, p.1)

If as a non-Aboriginal white scholar you wish to be an ally to our people then you should put marginalised voices to the forefront, stand back, and as stated earlier, put away your pen. And for our Aboriginal and black writers, who participate in such collaboration, just stop - it is time to say 'gabayiindah gaalanha yanaay' (thank you and move on ...). All rights of the white scholar in contributing towards our issues were forsaken after 500 years of colonisation, slavery and theft. This is where white privilege comes from and for all those who cry reverse racism while still enjoying their ill-gotten gains on stolen Aboriginal lands, their hegemony, comforts and accumulated wealth, the generations of head start and advancement over our people built on the sacrifices of our ancestors, I say this:

Your privilege was gained over the blood, sweat and tears of the oppressed, when that privilege now comes under scrutiny - whites who want to continue to hide their guilt by now contributing to our voice have no place in our emergence from the hell your people created. Across the globe we are still being shot in the street by white police, bombed relentlessly in our traditional homelands and here in Australia we continue to die in custody, live in third world conditions, and children as young as eight years are taking their own lives because they see no future - I have no time to argue or debate with those who refuse to admit to the truth or set us free... or those who hide by accusing my people of the very hate you created ...

The basic principle is that racism is taught, it has evolved and is maintained through education. Stating a combination of knowing the writers over a period of time, friendships made and having empathy with the people you oppress does not make you black, it does not make you Aboriginal. It does not mean that you will not taint our most precious agency, our knowledge production and intellectual property passed on by word of mouth from generation to generation with your white privilege and fragility, due to the systematic bias and institutionalised racism you represent. As Aboriginal people we have had to fight for every acknowledgement we have received in breaking down the hegemony of your power relations (Mander et al., 2011) embedded within the Western academy - white people have given us nothing, we have fought for everything we have. As an initiated ceremonial Kamilaroi language speaker and writer I remain opposed inherently to the requirement that the marginalised member should adopt the privileged member's assumptions, ideologies, values and indeed their very culture in order to become legitimate. 
When the slave takes the slave master's whip and whips the slave master with his own whip, that is not reverse racism or reverse discrimination; that is the slave getting out from the yoke of bondage and oppression.

(Muhammad, 1994)

When will non-Aboriginal white scholars realise that attempting to shape or understand something as timeless and connected as our Aboriginality within your own institutional values is not only demeaning, it maintains colonialism and it is racist? Simply admit that we are unique, and that your role here is to accept you do not understand everything there is to know and at times you are better served by simply listening. As an Aboriginal black man and as a father I spend my life negotiating whiteness, and as a white person you spend your life attempting to control my blackness. It just is not fair, it is not right and it has to stop.

I do not make such statements lightly, but in recalling the central role of the intergenerational teaching practices that have moulded my childhood subjectivities - I have gazed inward at the background, ideology and our location in what can only be identified as a neo-colonial landscape, and I ask myself how we can use labels such as post-colonial when it is still happening. That segregation, labelling and white privilege continues to silence my voice and more importantly my people continue to suffer. I have been forced as a coloured person who shares both this privilege and the pain in being mixedrace and educated to question my work as a social justice educator, and my public writing. Have I taken strong enough action in contributing to the changes we as Aboriginal and black people seek for our children? Is my language strong enough? Did I censor myself ...? Well, not any more. One day I hope to embrace my whiteness in the same way I claim my blackness, but for now, due to our collective fight for truth, I am reminded of the need to forge a relationship across the globe in unity of Aboriginal and black people as solidarity against violence and aggression. Therefore in screaming my blackness to the world I must remain extreme in my stance, loud and proud in my identity, in order to counter the imbalances we face daily. Semali and Kincheloe (2002, p.19) confirm 'it is important for [I]ndigenous people to have informed allies outside of their local communities' in gaining momentum and personal agency equipped to withstand oppression, making our struggle global and united around the Western world. I stand strong in citing the words of Assata Shakur, the godmother of Tupac Amaru Shakur, when she said ... 'Nobody in the world, nobody in history, has ever gotten their freedom by appealing to the moral sense of the people oppressing them' (Shakur, 2016).

But for me to reach such a position personally, rather than such unity being focused on our dispossession, I have found my identity from the inspiration of the Maroons' autonomy, and the Māori rangatiratanga translated as: 
My divine authority and birthright to exercise autonomy, ownership and leadership in carrying the attributes of my personal magnetism and inspiration as an Aboriginal person.

In my own Kamilaroi we have a word very similar called dhu, meaning:

My right of place, pathway and connection to my ancestors as a collective consciousness directly related to the universe and its creation, as allpowerful in maintaining my spirituality over tens of thousands of years as the very essence of my very being and consciousness.

It is here within our collective Aboriginal and black communities across the world that we will find the answers again in sustaining our cultural traditions among the youth we work with in our communities. It is here outside of the academy that we have the answers to centuries of colonisation and oppression imposed upon our children currently failing in Western schools across the globe. It goes without saying that radicalised action is needed to disrupt the social injustice that persists in the classrooms of these Western developed countries and our communities where Aboriginal children continue to perform well below white students (Kanu, 2006). A ten-year study, 1999-2009 (Purdie \& Buckley, 2010), investigating Australian Aboriginal children retention rates in high schools reveals that they are leaving school prior to graduation at rates almost double those of non-Aboriginal children, who are going on to complete high school. The study highlights that the percentage of non-Aboriginal students aged 12 years (grade 7) who remain in school is almost double that of Aboriginal children; 73 per cent compared to 35 per cent in 1999. Aboriginal students are almost twice as likely to have left school before year 12 in the senior year, with a 40 per cent graduation rate compared to 77 per cent of non-Aboriginal students in 2004. In 2009 not much had improved, with only 45 per cent of Aboriginal students graduating high school in comparison to 77 per cent of non-Aboriginal students. Overall, the apparent retention rate for full-time Aboriginal students from their first year of secondary school through to graduation of high school in 2009 was 32 per cent lower than nonAboriginal Australian students. Back in 1999 when the study began, the percentage point difference was 38 per cent (Purdie \& Buckley, 2010, p.6).

In the United States, the achievement gap between white and black students has persisted over decades in spite of reform efforts. Black students continue to score below their white counterparts in all areas with a notable 31 points lower in grade 8 mathematics, for example. On a national average, 67 per cent of blacks and 57 per cent of Hispanics graduated from high school annually in comparison to 81 per cent of white students (National Council of Education Statistics, 2015). This and the Australian Aboriginal example will remain unchanged until we instead choose to embrace the funds of knowledge these children carry with them, their culture and identity they bring into the classrooms. There has to be a conscious shift away from the deficit model 
used currently which is preventing our children from flourishing. As people of colour, it is more important now more than ever to move from critique to project, from negative to positive deconstruction as separate and yet equal to each other. We must reinvent the black and white relationship in such a way that allows for a move beyond the binary and its associated power relations.

This collective global solidarity is shown in our own autobiographical ethnicity demonstrated in not only my writing this book, but more importantly as a conduit for something much more powerful happening outside of white classrooms and within our own black and Aboriginal communities across the world. As within our communities, our young people, our marginalised, are confronting and disrupting injustice as protest in utilising social media and technology outside of the hegemonic principles that once denied their voice. We are becoming witness to an emergence of a newly formed resistance class of black and Aboriginal youth rising from outside of the Indigenous academy and traditional forms of media. Having been let down by traditional means of Western media and education, they have turned to social media established from outside of these Western institutions and are now facilitating our own examination of the complex nature of our reality and (our)selves - from outside of what was once a contained space (Boylorn $\&$ Orbe, 2014). It allows us to simultaneously tackle our isolation and honour our Aboriginality and blackness in collaboration within our own voices. Social media assists us in levelling the playing field by breaking down hegemonic barriers that once separated our youth into insider and outsider categories - the privileged and the dispossessed (Serafini, 2012; Solorzano \& Yasso, 2002). This has been essential to a journey characterised by new forms of resistance in movements such as 'Black Lives Matter' in the United States and 'SOSBlakAustralia' in Australia where we create our own framework to provide some order and accommodate our individual approaches outside of the institutions that have kept us out and silenced us for so long. In placing the lenses on ourselves, we have utilised digital media to facilitate our qualitative inquiry as we battled the challenges of time zones and distance; developing confidence in communicating across the barriers we face together. Social media allows youth the space to examine and present their world as they create it instantly in sharing counter-narratives that reflect their racial and social realities. For Aboriginal and black youth once marginalised, it empowers their voices in ways never before realised. They are able to peer imaginatively into the lives of other youths across the globe, make comparisons and connections toward meaningful change, and represent those changes in powerfully created texts as they happen. In other words, the fourth wall of traditional media as the greatest form of immediate communication has been broken down; not just broken but also shattered.

As educators it is our privilege and our responsibility when educating youth to empower their unique experience as adolescents engaged in a rite of passage connecting them to their heritage, their history and their identity. This is achieved in teaching communication through creative writing and 
expression, and in acknowledging what is happening in Aboriginal and black communities outside of the classroom. In writing through reflection we can reinforce how such rituals remain significant, to not only the youth themselves but also their responsibility to their community. Digital technology allows us to communicate across continents, delving into the reservoir of our heritage and the particularities of our locations as data to inform our inquiry in applying qualitative methodology including autobiographical ethnicity ... as writing to explore these landscapes and assert our voice as original. We must encourage these youth to then tap into the liminal space this opens up to us a space in non-linear time that accesses thousands of years of ancestral Aboriginal wisdom, creation, innovation, together with the African diaspora and its cultural retentions. An important step in this journey has been in interrogating the intertextuality of our narratives, weaving together the mutual connection of our black identity as an ancient Aboriginal heritage. Boylorn \& Orbe (2015) demonstrated how such self-study becomes an interrogation/reflection of the self as researcher and practitioner, positioning others within our international community as the critical allies within this third space as we move towards a journey of self-improvement and healing in recognising each other's voices (Milner, 2007).

As members of a global community it is our responsibility to provide valuable critique, questioning, exposing, pointing to possibilities beyond the immediate, reminding ourselves that we are inheritors of a cultural legacy based on the inter-relatedness of all things (Martin, 2008). Racial unrest across the globe played out in social media is nothing new in theory, only in practice as evidenced dating back to the works of Paulo Freire (1993; Freire \& Macedo, 1987), to emphasise the urgency to pursue critical steps to engage our children as effective participants in a globalised environment. As Freire (1970) argues, education is a critical force in working to conscientise a system that has sought to maintain unequal power relations and silence the voice of selected people; the answers have always been there, but it is the power structures set in place that deny them being played out. Our inquiry as Aboriginal and black people is continually exacerbated by the emotions that overcome us as witness to the continuing tide of racial injustice against our youth across the West. In the face of mounting frustration, Eric Garner's choking death at the hands of police in 2014, becoming viral and giving momentum to the 'Black Lives Matter' movement after we were already confronted with the resurgence of brutality against black youth - with the grand jury's failure to indict policeman Darren Wilson who shot unarmed teenager Michael Brown in Ferguson, Missouri. As the Eric Garner case unfolded, YouTube and Facebook videos showcased images of youth within the United States and soon, across the globe, united in protest against injustice. Photos of another, Trayvon Martin, cut down in his prime, resurfaced and added to the intensity of the narrative, which had now burgeoned into a social movement rooted in Black Lives Matter. The poignant image of Trayvon, hoodie draped over his head, framing his face as he peers out in youthful 
innocence, initiated a critical analysis of symbolic representation across Aboriginal and black communities across the globe. The Eric Garner case gave us flashbacks to Michael Brown, to Trayvon Martin, to Rodney King, to Emmett Till, as agentive action was occurring simultaneously in Australia as the unfolding of digital resistance through SOSBlakAustralia was working similarly to Black Lives Matter to change the relationship between ordinary people and people in positions of power. Here was the fusion of black identity with African and Australian Aboriginal First Nation, Māori in New Zealand and the emergence of the Dakota Access Pipeline protests, also known by the hashtag \#NoDAPL, became grassroots movements that highlighted not only Aboriginal and black resistance but more importantly white fragility in its hostility against people of colour 'who dared speak out' for and on behalf of themselves. But as whites became more angry, more hostile, there was solace within our communities in the awareness that across countries and continents this global community was asserting its wealth of knowledge in creative ways, enacting the historical continuity of their resistance against white neo-colonial oppression. Here was the evidence that grassroots leadership had been harnessed into collective action for change. From remote Wangkatjunka Aboriginal Community in the Kimberley region of Western Australia, Nelson Bieundurry posted the following on Facebook, on 11 March 2015:

Hmmm, maybe the best question to ask is this, do we even give a sh*t about what's happening to us now? The truth is ... if you're a Blackfella and you live in the Kimberley ... in one way or another ... this is going to affect you.

The post was written in response to the then Australian Prime Minister Tony Abbott's comments that the Commonwealth could no longer fund essential services in remote Aboriginal communities as Aboriginal people living on their traditional homelands were making 'a lifestyle choice' rather than fulfilling any cultural obligation (McCarthy, 2015). Western Australia Premier Barnett then recommended the closure of over 150 remote communities, which would create over 20,000 traditional homeland refugees in their own country (Wahlquist \& Davidson, 2015). The voices of the community rallied quickly via social media, becoming the SOSBlakAustralia movement, driven through a website founded by Sam Cook, a Nyikina First Nation woman from Western Australia. An estimated 25,000 people marched in a call to action around the country against the closure of remote Aboriginal communities, with rallies taking place in Brisbane and Sydney. Then the world took notice as a third demonstration of over 30,000 in Melbourne resulted in a major city standstill, which I referred to earlier at the start this book, writing it as it was happening. As the voice of the people united in protest across social media, Premier Barnett 'distanced himself from comments' that his government would force the closure of remote Aboriginal communities (Wahlquist, 2015), and with his popularity at an all-time low after his comments, Abbott 
was unable to survive a leadership challenge (Davidson, 2015), losing his position as Australian Prime Minister to Malcolm Turnbull in September 2015.

We were always told that [his]tory was written by the winners, but for the first time history is being recorded as autobiographical ethnicity as it is happening around us. Before this, unbeknown outside of our community, we were also carrying history as spoken word and ceremony parallel to the Western denial and lies maintained in classrooms and books written by ageing white men ... but now for the first time young Aboriginal and black youth are documenting, recording and identifying truth as it is happening on their mobile phones, Instagram and Facebook pages, and the evidence keeps piling up, the black deaths keep coming. Burrows (2016) conducted an extensive review of social media literature, in which she identified the extent to which the mainstream media once continued to portray Aboriginal peoples as 'outsider[s]' (Roth, 2005, p.214). Citing Squires (2002, p.460), Burrows also points out how digital media more recently has overcome such censorship in reaching the 'counterpublic' phase as seen with SOSBlakAustralia and Black Lives Matter, and more recently \#NoDAPL heavily influencing public opinion. There is much work to do, and this will take time; but it is a story of innovation and resistance which has been developing for centuries.

We acknowledge that change will not be immediate, but digital tools have allowed us to engage in reciprocity across the globe; Aboriginal and black people making incremental change on a conscious pilgrimage of transformation. Our voice had been raised in unison where hegemonic forces could no longer silence us. I can't breathe. I am Trayvon Martin, or as spoken in my own Kamilaroi tongue ... Baluwaal muurr gi gi ngaandu nginunha-barra! (Never forget who you are ...); Baluwaal miinba-y nginu-ngay giirr wangaarrama-li! (Never allow yourself to be beaten ...). As witnesses to Black Lives Matter, SOSBlakAustralia and \#NoDAPL we engaged in an anticolonialist discourse which allowed us to explore racial oppression and cross over its limitations in a critical partnership based on traditional Aboriginal parable, black culture and storytelling. While we acknowledge that this achievement is a small step in a long journey to disrupt the continuation of global racism, we celebrate the way it legitimates the power of youth and disrupts the outsider and insider power paradigm. Along with millions across the world, we accessed primary source stories in which youth became coauthors, shattering the single story paradigm. In this massive cross-cultural story mapping, youth chooses from a multimodal landscape to define and perform themselves via the voices of their own communities. This ideology of solidarity across borders has highlighted the importance of digital media in giving voice to youth who encountered and developed one another's strengths; youth who were troubled by the history and perspective of racial inequity and spoke in defiance to a society that upholds whiteness as the norm and racism as a personal problem. 
As witnesses to the possibilities of criticality (McLaren, 1995), we have incorporated these narratives as experiential pedagogy into our developing discourse globally. This collaboration reaffirms the interconnectedness of Aboriginal and black people across non-linear timelines. Further, it emphasises the power of digital technology to disrupt imposed limitations and map imaginative geographies across the continents in expression of the entangled subjectivities of oppressed peoples (Hull \& James, 2006). Against all odds Aboriginal and black youth have demonstrated how social media enabled their story-making, inspiring them to cross borders and identify strategies to change their world (Giroux, 2001; Husbye et al., 2012; Serafini, 2012). As youth actively engage with each other across the world, they will participate in the broader narrative, recognising that this is a worthwhile accomplishment, it is affecting how they see themselves, and it is affecting others (Lankshear \& Knobel, 2006). And, as our Aboriginal and black youth experience and affirm in chorus around the world ... 'I am that change'. 


\section{Minya burrul burranba-li mubirr (What inspired the writing ...)}

I began writing this book over three years ago in wanting to move beyond the limitations of contemporary Indigenous studies and to deconstruct my Aboriginal identity not as a victim, but as a survivor who displays strength, innovation and clarity in a world of confusion and racism. I wanted to write in reaction to how within the humanities the focus has been on disadvantage and/or related activities such as welfare dependency, domestic violence and substance abuse (Martin, 2001). I wanted to illustrate how our own pedagogy as epistemology among Aboriginal people, both in Australia and the world, can have a far more reaching effect on how individuals, both black and white, can choose to live positive lives. That Aboriginal culture, rather than be seen as a disadvantage, can instead lay the foundation and/or structure for positive pursuits built on cultural identity, honesty and integrity (Grieves, 2009). For many Aboriginal people, a long-term interest in cultural maintenance and language requisition has led to them pursuing a range of creative and influential careers often ignored within mainstream media and Indigenous studies focused instead on disadvantage. We have, for example, many successful cultured language speakers who have achieved quality of life and balance in the spheres of writing, art, music, film, sport, health and education, too many to list here, but very rarely do we read about them. For others, being connected to their traditional culture with an ingrained political content has led them to choose careers with a proactive social and/or political agenda, contributing significantly to their communities in environmental and sustainability management associated with traditional owner groups, working with the homeless, the most vulnerable, in counselling or in Aboriginal housing or health, and even Aboriginal legal services making better lives for others, families and their communities. The career paths chosen by many Aboriginal people committed to their culture are highly varied, concerned not only with cultural integrity and maintaining traditional kinship systems, but also the production, distribution and provision of local community advancement and capacity building.

Just now, literally as I am writing this, I have become aware of an economic deal done between the Traditional Aboriginal Wik people in far north Queensland, Australia, who have signed an economic treaty with an 
international business consortium from China. The economic treaty will see them export wood from tree lopping in a plan to recycle and export wood chopped down which was being burnt for land clearing by mining giant Rio Tinto. Instead of environmental waste, the deal, reportedly worth $\$ 600$ million, will include building a sawmill in their community to provide jobs for the local Aboriginal people and also the replanting of trees and rejuvenation of traditional country (Bandicootcha, 2017). There was no mainstream coverage of this enterprise at all ... I only became aware because of my links in the community.

This highlights my wanting to write this book in giving a voice to our people in showing our ongoing endurance and adaption as we evolve and continue to survive into the 21 st century. Not just survive, but flourish despite the never-ending obstacles, segregation and barriers we face. As much as I wanted to remain positive, contribute to a narrative of healing, I found I was also writing constantly on the trauma and the disadvantage many of us face. Obviously I was not ready yet to be set free. I could not ignore my own trauma, let alone celebrate any sense of homecoming in writing such a book without answering first much of the pain I have associated with my own past. So often as Aboriginal people we are told to leave the past behind, move forward and embrace our future. Don't look back, only forward; but what do you do when the very essence of your being is associated with your ancestors... what then? Are we meant to leave our Aboriginality behind with the pain they carried so we can be free - be free from what, our very Aboriginality? No, the very principality of who we are and what we represent is acknowledged in our past. I have been privileged to have travelled the world to stand on many Aboriginal lands in respect of our people, and whether I be with the Ngāti Kahungunu in Hawkes Bay, Aotearoa New Zealand, or the Maroons of Jamaica, the Cree-Stony in Turtle Island, North America, and my own Kamilaroi people of Australia ... the very origins of our consciousness, our very being and identity come from our relationship with our ancestors. So again I ask you ... how am I meant to leave this behind ...? The simple truth is I can't, so instead, rather than leave the past behind, what we should be asking ourselves is how do we take it with us and not become trapped in the trauma it carries - because let me tell you it carries some trauma. And it was this very same trauma that sabotaged and/or hijacked the very intention of this book.

As stated, my intention was to write something positive to counter the negativity we are immersed in, the very victimisation we are accused of ... instead I only discovered that before we can become healthy we have to confront the pains of our past, acknowledge our mistakes and carry forth our scars, visible to all who know us. This is hard when we live in a society that encourages you to hide the truth. The problem was in trying to establish a unique Aboriginal voice via autobiographical ethnicity. The very solution becomes my problem as indeed in being autobiographical I was unable to write without acknowledgement of the pain I feel deep within me, and then as 
ethnicity this is also shared within the pain I have endured collectively as an Aboriginal person. You can't just shut it off, and move forward and start again as if born without some form of recognition. The problem with the world, I believe, is that we have not healed the wounds of our past. In healing yourself first as an individual you then help those around you. I liken it to the safety instructions on an airplane, always put the mask on yourself first before helping others ... The problem is that these others who have brought trauma and, yes, violence into our world having caused so much of the pain associated with our history are nowhere near any process of healing. We only have to look around at the world they have created - the ones with the power and the influence who are running things. One thing I can tell you quite clearly is that in this world of post-truth, the people of colour, those on welfare and others living within the third world, just don't have the influence to be the cause for all this hate and pain we are seeing; we remain just the easiest to target, to blame ... the most vulnerable, nothing more.

The recent narrative occurring both in Australia and the United States regarding monuments and dates dedicated to mass murderers, invasion and slavery highlights this significantly. Watching whites who dominate every quality of life outcome in both countries become incensed with rage over questions that expose their fragility is quite revealing. In Australia, where white privilege is so unadulterated and pure due to its isolation compared to the United States, we see racist comments together with hostile aggression almost daily portrayed throughout the media. Australian journalist Andrew Bolt is just one example where recently he wrote an article 'full of vitriol'. Accusing the Darebin City Council, which along with the Yarra Council has agreed to no longer celebrate Australia Day, of 'totalitarianism' and 'wiping out our history' and comparing their leadership to the 'Taliban left' and that of 'Stalin and Mao' (Liddle, 2017).

All were Leftists who feared having the public reminded by monuments or ceremonies that greater people with other gods built the glories on which these new tyrants stood. The Greens of Darebin - and Yarra council - are puppies of this same dangerous breed, rating themselves infinitely more moral than all who went before yet scared we won't agree.

(Bolt, 2017)

The Australian Prime Minister Malcolm Turnbull cited such actions taken by Darebin and Yarra City Councils as 'utterly out of step' with Australian values and has denied them federal funding as a consequence of their decisions. Then there was the clash on breakfast television between conservative commentator Prue MacSween and Peter FitzSimons in what again became a fiery debate with MacSween raising her voice, virtually yelling at FitzSimons in saying the following: 
it really concerns me that people want to enter into this revisionism of history. Whether you agree he discovered it [Australia] or not, the point is he came here and the Aborigines were, I believe, reasonably well treated. There were some, obviously acts of genocide in certain parts of Australia ... [but] Phillip was very kind to them in a lot of ways. ... Why [do] we have to flagellate ourselves all the time?

(MacSween, cited in Court, 2017)

Only white Australians would use 'genocide' and include phrases 'reasonably well treated' and say that Governor Phillip 'was very kind to them in a lot of ways' in the same sentence without blinking. What is transparent with each and every example is the enraged anger witnessed by those defending the right to maintain memorials to mass murder and invasion ... you would think they are the ones having to live with racism and trauma in their own families, but instead they only reveal their fragility with regards to a couple of statues, place names and a date with no idea they are in reality siding with Nazis in Charlottesville and the United States. I have spent a lifetime in Australia banging my head against such ignorance, which now finds me living within the sanctuary of New Zealand.

I have to admit that going back to Australia both for work and family is like returning to a crime scene, so difficult the history and obvious racism to face. The difficulty is in how oblivious Australians are to the ordeal we suffer. I cannot describe or write in words the journey, obstacles and/or sacrifices I have made as an Aboriginal man to finally reach this last chapter of the book. I may have physically started writing just over three years ago, but to first obtain the personal agency, the social mobility and the degree of scholarship to negotiate my path has been extremely difficult. Now that we have arrived, I want to take this opportunity with both hands; I refuse to censor myself as the writer nor you as the reader having invested so much together to get here, for both of us I can't afford to now play it safe. Therefore in working towards my conclusion and having jumped over the academic hurdles required to get here, and in order to say thank you for persisting in staying with me, I now move from the academic text to more stream of consciousness prose, which in reality is how I would have preferred to write the entire book from start to finish. But discipline is good and academic scholarship is hard earned so I have no regrets, but from here on in this will be me completely vulnerable and naked in exposing my most inner thoughts directly to you ... having taken a lifetime it was important to me that by the end of this book I was able to just write without having to stop, consider, reflect and then find references that substantiated a position to create validity and truth to my audience, when quite clearly, as stated in the book, truth is no longer a concept we adhere to in the Western world, and the reality is we probably never have. Otherwise we would have realised long ago that the savages were not the ones occupying natural paradise, living off the lands in the way our God intended, but instead the ones who brought pestilence and disease, living in their own excrement, 
killing children and women, rapacious in their attitude, taking slaves and stealing the lands from those who had maintained them in purity for so long. These are the real savages as with those today, the ones who without remorse, lie and steal, chasing wealth and individual gratification as others starve, those who maintain slavery through financial debt and continue to benefit from the hardship of others in the name of freedom - justifying all that they do by claiming they are the greatest civilisation in the world. You see, I have realised in coming to the end of my journey that I have not written this book as an Aboriginal man opposed to colonialism or settler communities, but instead as a human being who has seen too much misery in the world. As Aboriginal, once we clear away the old statues and hegemonies belonging to those who have maintained hate and division for so long, we have something wonderful to share with the rest of the world. I am also convinced that the majority of non-Aboriginal people around the world would embrace what we have to offer, after having the opportunity to educate them on who we really are and what we represent. Such education is blocked by a small minority that profit from the misery of so many, creating an economy built on waste and indulgence that benefits so few dependent on the natural resources Aboriginal people owned prior to colonisation - what journalist and novelist George Monbiot refers to as pathological consumption preventing sustainability and human connection.

People in eastern Congo are massacred to facilitate smartphone upgrades of ever diminishing marginal utility. Forests are felled to make 'personalised heart-shaped wooden cheese board sets'. Rivers are poisoned to manufacture talking fish. This is pathological consumption: a worldconsuming epidemic of collective madness, rendered so normal by advertising and by the media that we scarcely notice what has happened to us.

(Monbiot, 2012)

I say this having been part of the over 30,000 who closed down Melbourne three years ago and witnessing the 50,000 who attended Invasion Day protests in the same city against the Australia Day celebrations earlier this year (Liddle, 2017). The majority of non-Aboriginal both in Australia and the United States are not white supremacist Nazis carrying swastikas and torches. And even though Australian breakfast television is having trouble coming to terms with racism, all of a sudden genocide is a word used freely and openly whereas only nine years ago it would have been received with a steely glance and silence. And then there was the human grief and protest displayed by those who host American night time television as a complete contrast to what's happening in Australia, where the US President and the country were put on notice that any values and/or connection towards white supremacy and racism is simply unacceptable. The very fact that we are having this debate in 2017 regarding monuments dedicated to hate, racism and slavery 
tells you that those in power may still be wielding their institutional authority ... but their influence over both the United States and Australian public is waning. People are getting sick and tired of racism, the division and the hate it manifests. The reality is that if we do not have this debate, if we do not raise our consciousness to consider other races, other alternative views and our relation to our environment, we will eventually implode. Every other great 'civilisation' claimed as having contributed to the origins of the West, from Babylon to Ancient Greece to Rome, has fallen and you cannot build on rotten foundations. Rome only lasted as long as it did in raping the resources of Africa; it was never self-sustaining. Just as the West is dependent on natural resources around the world, it too will eventually collapse. Eventually, due to over-population, environmental disaster and decadence, having never consolidated their position within nature or something even bigger, perhaps even God, the universe and all its creation will have the final say. For all their technology, advancement and sophistication they lack understanding of longevity or sustainability which is essential in maintaining the Aboriginal experience in having survived for over 80,000 years. We have seen all these empires come and go, and the reality is that with current debate enshrined in the international community our position is becoming stronger, not weaker. We may not have the social and cultural capital, the control of multinational companies and political influence within the world's economies, which are failing miserably, by the way ... but what we do have is our relationship with nature, built on self-sustaining cultures via humble principles of biodiversity established on kinship systems contained within bloodlines that laid the foundation of our understanding over tens of thousands of years. This was until we were introduced to a rapacious culture driven by the most primitive needs to control everything around it ... a scared savage creature driven by its fear of the unknown, having to conquer all in its path with absolute destruction. A creature lost in a world it did not understand, forced to wander aimlessly, spreading like a cancer, never having found peace or able to consolidate the lands gifted to them by God and creation - if only they had reached the same level of civilisation as ourselves, where we would never have had to feel the pain, the misery and devastation they brought to Aboriginal people having to leave a disease-ravaged Europe overcrowded and living in its own filth.

As Aboriginal people we have always been connected to the land, never having to wander aimlessly or conquer others. Where our creation is formed from Burruguu-ngayi-li or the Dreaming, what my family call the Burruguu. A time which first gave birth to life we call Gamilu Bidi-Wii or Before the Big Light or simply 'before the beginning ...' we remain even today connected to this time before the beginning which gives us place and belonging among the madness. There are still those today, ceremonial men and woman revered in our traditional communities, who share consciousness in the introduction of our ancestral beings, called the Maran Dhinabarra, responsible for all of creation. Those who via deep reflection remember when we were first given 
birth to consciousness, via a conversation we call Winanga-y-la-nhi over 14 billion years ago. But how do you explain to those so lost in consumerism, pathological in their racism that we are nothing more than the evolution of a conversation that took place between ancestral beings so many years ago when all life was born? Having been reared and spending so much time in Aotearoa New Zealand, I am also blessed to have been exposed to the Māori story of creation. They, like the Kamilaroi, share a story from darkness and light or Te Kore, broken down as Te Pō darkness, the night and Te Ao light, which first gave birth to our world. They, like us, also have Maran Dhinabarra - a genealogy of ancestral beings called Whakapapa; a genealogical chart of their ancestors that dates back to this time of creation. A time when a line of descent as one state of being is born from one to the other through a series of violent eruptions and explosions occurring as a sequence of events in giving birth to consciousness. As worlds emerge from other worlds, as the earth separates from the sky, out of which Ranginui, the sky father, and Papatūānuku, the earth mother, become life. In Kamilaroi we have Buwadjarr, the Creator Spirit born from consciousness, and Wadhaagudjaaylwan as Mother and giver of life.

This is where many in the West, and particularly those who turn to science for reaffirmation of their existence, struggle to understand the Aboriginal worldview, where birth of environment, flora and fauna dating back to stars and even the universe are accompanied with a sense of consciousness. That life cannot be so interconnected metaphysically and yet this remains the very essence of our Aboriginal thought processes.

I remember when I was first told our story of creation as a teenager going through my first level of initiation. My Uncle Reg said to us, 'there was always the Great Spirit, this spirit then gave birth to consciousness through a dream in conversation with Wadhaagudjaaylwan'. I asked 'how long ...?' Everyone stopped. I don't know how many generations had passed regarding the sharing of this conversation, there would have been a few ... or if anyone had asked this before, but the others, some as young as seven, eight years old who were much more immersed in their Aboriginal knowledge than I was despite my being much older, seemed frustrated with me. 'What do you mean ...?' asked Uncle Reg. 'You said the Great Spirit was always there, yeah ... and then he dreamed of consciousness in conversation with Wadhaagudjaaylwan ...' Uncle Reg interrupted, 'I never said "he", you did ... I just said spirit ...' I was completely lost. 'How long, how much time passed before the spirit dreamt of consciousness, you said there was spirit and then they dreamt of consciousness, how much time had passed, millions, billions or thousands of years before they dreamt of consciousness ...?' Now growing up among white people you feel a need to bring your own knowledge into conversations, to feel like you are in control. You watch ... white people do it all the time, turn conversations around towards subjects they feel comfortable with. Not having grown up among my own mob, I guess that's what I was trying to do, to sound knowledgeable by asking questions no one else was 
thinking ... as if somehow this made me look smarter than the others. Remember I was much older than most of the boys who grew up in their community going through the same initiation. Then there was also part of me that generally wanted to know how long this Great Spirit sat around before deciding to give life to consciousness. Uncle Reg just smiled at me, always the most beautiful, comforting smile ... 'There no time yet', he said, 'time gonna come much later ... much, much later ... no time ... just Spirit, Wadhaagudjaaylwan and consciousness, time gonna come ... later'. I was blown away, and finally I got it. As Aboriginal people we had been here forever, even before the beginning, before time... like the old people say ... Gamilu Bidi-Wii (Before the Big Light) ... before the beginning ...

How do you explain that to some white people who own everything and feel there is nothing you have to offer them? You can't. These are a people who rather than feel connected to the beginning, or even before the beginning, had to find faith in stealing Abraham's legacy out of Africa, turning Jesus white - which is perhaps how they condemned themselves to wander aimlessly around the world. As a child, whether or not you believe in a spirit, a God or consciousness ... what overrides Western influence out of Europe is instead evolution, not of a conversation from something greater than ourselves but in the idea that they came from an ape. That somehow consciousness had to become, be born or evolve over millions of years rather than always being connected to who and what we are and what we represent. And not just any ape, but an ape that they believed more sophisticated, civilised than the other apes - where we are led to believe that through a process of evolution picked up a jawbone fashioned into a weapon, killed all the other apes in a battle of the fittest ... where only the strongest survive. It is an image forever immortalised in the opening sequence of Stanley Kubrick's 2001: $A$ Space Odyssey as a black monolith appears to a group of apes at the beginning of the film. Set in prehistoric times, the monolith is discovered by a group of hominids and somehow triggers a considerable shift in evolution, starting with the ability to use tools and weaponry. Dobzhansky (in 1962) wrote six years before the film ...

it is obvious nonsense to ask which ape or monkey now living was the most remote ancestor of man or any other existing species than itself, because apes and monkeys have themselves developed into something else. But it may be asked whether there was a common ancestor of man and apes, or man and monkeys, and if so what was this ancestor like. A variety of hypothetical answers to this question have been offered. Man's ancestor was pictured as a brachiating ape who abandoned his life in the trees, descended to the ground, and lost the long, grasping arms.

(Dobzhansky, 1962, p.169)

Consciousness interconnected as a metaphysical landscape captured beyond the limitations of linear thought and time are concepts that drive the premise 
of the (2014) film Lucy written and directed by Luc Besson. The protagonist Lucy, an unwilling drug mule, is accidentally overdosed with a drug that triggers a number of pre-encoded genetic abilities, opening her mind within greater metaphysical understanding of both nature and time in which Lucy comes to the realisation that time remains the only true measure of human life and existence. Towards the end of the film she takes an existentialist journey towards enlightenment, transforming into a next-generation supercomputer that contains all enhanced knowledge of our universe. It is a journey that takes her deep into our past, eventually reaching the oldest known ancestor of mankind within Western civilisation known in popular culture as 'Lucy'. The Lucy specimen is an early australopithecine and is dated to about 3.2 million years ago. The skeleton presents a small skull akin to that of nonhuman apes, but importantly her skeleton gives evidence of a walking gait that was upright, like that of humans. It is a combination that supports the view of human evolution which comes full circle in the film when Lucy the human touches fingertips with Lucy the Ape in the same way E.T. the ExtraTerrestrial made famous, touching the finger of the young boy Elliott who saves him in the (1982) film. The most famous reference though in regard to fingertips touching and origins would have to be in Michelangelo's 'the Creation of Adam' as part of the Sistine Chapel's ceiling, painted between 1508-12, taken from the Book of Genesis where God touches fingertips with Adam - breathing life into him as the first man. Lucy goes back even further than the creation of Adam, witnessing the Big Bang after reaching 100 per cent of her cerebral capacity before disappearing within the space-time continuum. It is from here that Lucy explains that everything is connected and existence is only proven through time, with the film ending via a text message sent by Lucy from within the consciousness of existentialist space that reads: 'I am everywhere' (Besson, 2014).

Needless to say, despite returning to Africa and the origins of our creation, within the film is further evidence of cultural appropriation taken from many of our Aboriginal creation stories as outlined above in both the Aboriginal and Mãori creation stories. Stories that also capture consciousness as interrelated, documented and recorded by Aboriginal people in the form of our Whakapapa and Maran Dhinabarra as ancestral beings that link to our universe and creation within our own consciousness some tens of thousands of years before Besson ever conceived the film - rather than using an actress of African or Aboriginal descent or black ... just as with Michelangelo's depiction of God and creation as white ... Lucy is played by Scarlett Johansson, a white woman, in maintaining one of the greatest known conspiracies throughout any civilisation, that somehow white people magically appeared before black people and gave us civilisation despite all the evidence that proves the contrary. Such references within film and popular culture that maintain white superiority within cultural appropriation are endless and include the story of Pocahontas, once described by black actress Robinne Lee as 'the Indian woman leads the white man into the wilderness, and he learns 
the way of the people and becomes the saviour ... It's really upsetting in many ways. It would be nice if we could save ourselves' (Singh, 2010). And then there is more recently James Cameron's 2009 film Avatar, described by New York Times columnist David Brooks, as:

racial fantasy par excellence ... It rests on the assumption that nonwhites need the White Messiah to lead their crusades. It also creates a sort of two-edged cultural imperialism. Natives can either have their history shaped by cruel imperialists or benevolent ones, but either way, they are going to be supporting actors in our journey to self-admiration.

(cited in Singh, 2010)

It is a narrative played out over and over again, as with Kevin Costner's (1990) film Dances With Wolves and the Tom Cruise (2003) film, The Last Samurai. At least in these films mentioned we get to play supporting roles. In Lucy it is only the concept of Aboriginality and consciousness stolen, with Morgan Freeman playing a supporting role, but only as an individual, not as representing an entire race. In moving away from popular culture where further examples date back also to blackface and even earlier with too many to mention, I also began writing this book in wanting to deconstruct how the practices of social capital, agency and localism continually benefit white people, whether it be through film, popular culture, business, the academy, industry or politics. And how is it that advantages remain organised through race, education and the institution, and also to analyse the economic, cultural, social and political forces that influence this advantage as a form of white supremacy? It becomes apparent that in moving away from existentialist faith systems, though beneficial in popular culture and storytelling - that Western culture outside of 'fantasy' and 'entertainment' holds up science as fact. That science, not faith equates to progress, pre-history as evolution, and ancient history as civilisation. More recently such rationale defines capitalism as progress (Calabrese Barton, 2001), formed around the idea of human advancement. Such an interpretation is even more evident today (Office of the Chief Scientist, 2013, p.10) in an environment that sees neoliberalism and austerity politics used as justification in reinstalling past binaries against black and Aboriginal people, defined as conservative politics with 'devastating effect' (United Nations, 2009, p.60). All of which is working directly against Aboriginal prosperity and inclusion within contemporary society (Lovell, 2014, p.225). History has then become a reflection of what I as a person of colour despise. As those who have written history have done so at the very vengeance of my own people out of fear ... fear of the truth ... fear of accountability and most of all ... fear of being outed as the very problem they themselves have created.

In wanting to escape from such history I remember in my early twenties going on a pilgrimage of discovering my own blackness. I packed my bag with ganja, marijuana or in my own Kamilaroi language, yarndi, about half a 
pound, and went on a trail down the east coast of Australia staying only on Aboriginal missions or reserves. As stated by hip hop mogul Jay Z, and many other black entrepreneurs, and as I gave reference to earlier in the book, for many of us in our communities the only currency we carry is in dealing drugs,

crack was everywhere - it was inescapable. There wasn't any place you could go for isolation or a break. You go in the hallway; [there are] crackheads in the hallway. You look out in the puddles on the curbs crack vials are littered in the side of the curbs. You could smell it in the hallways, that putrid smell; I can't explain it, but it's still in my mind when I think about it.

(Jay Z, cited in Robinson, 2013)

The yarndi was my currency rather than money, and I had completely cut myself off from the Western world and this was all that I knew back then, but it was a long time ago. I had recently separated from my first love, the mother of my first child, and had spent time living off the land in exclusion near the Glass House Mountains where the Bunya ceremonies were once held. I had taken my brother's property after he had to leave quickly with still six months remaining on his lease and it was there I grew the yarndi I needed. I then spent the next 18 months immersing myself in my own blackness. I was a renegade, an outlaw, and chose to not even talk to white people. It was wonderful. I only listened to black music: Toots and the Maytels, the Aboriginal band No Fixed Address, Bob Marley, Nina Simone and many others. I also only read black works: Steve Biko, Marcus Garvey, W.E.B. Du Bois, James Baldwin and many others. It is so sad that the rest of the world misses out on such an education. You see, I was not introduced to any of these scribes while attending high school; everyone and everything I was taught within any structured institutionalised education was ... white. I had no idea at the time I was going through what I would call today a process of decolonisation, but looking back that was exactly what I was doing. Every conversation, every book read, every beat of music listened to was black. My life would never be the same again. It was coming back from this pilgrimage that I met my second love and the mother of my other children. Unfortunately that relationship too would not last ... circumstances detailed at the start of this book eventually leading to the end of that relationship also. What I learned was that in their own forced exclusion, white people fail to consider their own fragility, that in their sense of superiority they fail to consider that there may be an alternative way of seeing the world, one that is built on connection rather than materialism, belonging rather than searching, harmony rather than conquest, and spirit/faith rather than science. As a Kamilaroi Australian Aboriginal black, in my identity I have always, whether I knew it at the time ... explored the tensions created through contemporary Aboriginal deconstruction of our own historical consciousness - it worries me today 
when I see black celebrities, such as Morgan Freeman, Larry Wilmore and Raven-Symoné begin to assert their individual identities as American over and above their cultural maintenance in having originated from Africa. Maybe not my place to say, but we have too many Aboriginal kids who look up to black Americans to not make some comment.

First of all, nobody wants to be called African American anymore. ... It just makes me think of Africa. And to be blunt, I am not that crazy about Africa. I mean, I know that's where we come from, it's our heritage, and blah, blah, blah. 'Africa' just makes me think of hot. A hot land where you have to hunt for your food, black people speak French, and you might get malaria. I'm sorry but that's just not very sexy. And if I want to be around black people who talk different in an unbearably hot environment where my ancestors once roamed, I'll go to the check-cashing place.

(Wilmore, 2015, p.4)

I remember years ago I was in the Northern Territory attending ceremony and many of the old people were confused that after attending initiation many of the young men were still drinking, abusing their woman and not conducting themselves in behaviour attributed to ceremonial men. You have to know that back then it was still customary to not look a woman in the eye, let alone talk to her; you just weren't allowed. In fact, a mother-in-law would go through an entire relationship never speaking to her son-in-law. The people out there live in the desert, you can't survive unless you are disciplined and ritualistic. Times were changing. You could buy porn, drink and even go to a tittie bar, the Devil had moved in and everything was changing, but still these old people couldn't understand. These ceremonies, these laws had stood for thousands of years, allowed their people to survive in some of the harshest areas known on the face of the earth. It wasn't until I showed them a television commercial with Michael Jordan, I am sure those who saw it remember it. Michael is standing below the ring at the free throw line looking up at the basket, suddenly he leaps into the air in that magic pose, you know, one arm outstretched the other holding balance, legs apart as if he was flying through the air, the famous silhouette that sold millions of shoes made in third-world sweatshops by Aboriginal children across Asia ... all of a sudden it didn't matter if you were Aboriginal, Māori or African ... going through initiation rite of passage or not, if you were black, coloured, brown or even white there was only one thing you wanted to be ... and that was Michael Jordan.

Now, I understand such strategy as outlined throughout the text ... that in gaining social capital and agency we can become accepted beyond the trauma of our past, but as stated, what makes us unique as Aboriginal, and as black beyond the colour of our skin is indeed our past. Beyond our trauma it is equally important to mark our progression as a movement of endurance and survival as a people, and not just via commercialism and again being used as 
slaves, we can never forget who was making those shoes Jordan was wearing and how much they were then sold for with little to no profit going back to the children who made them. No different to Aboriginal art being sold for tens of thousands of dollars while the woman who painted them lives in thirdworld poverty. No ... we can still move forward, but with dignity, respect and our heads held high ... if I could steal a phrase from Michelle Obama ... 'as we move from the slave house to the White House'.

Throughout the text I have purposely resisted looking at the unique distinction between Aboriginal and black. This book does not allow me the space to go there, so complex its subjectivity where in Australia we are one and the same, but I remain aware as stated above that in the United States many are resisting their past as slaves taken from Africa - instead identifying as purely black. For this group, African-American is not their identity but instead seen as a misleading connection to a distant culture no longer part of their immediate lives, or sadly, I feel anyway ... for many not even relevant. But as stated, make no mistake, Australian Aboriginal is a black race. The debate resurfaced after the inauguration of America's first black President, married to a strong black woman in her own right, and together with their two daughters, the first black family moved into the White House. Their black identity raising the questions of how this new First Family would fit into the history, the present and the future of a country built on slavery. We didn't have to wait for long, where First Lady Michelle Obama often appeared more outspoken than her husband Barack Obama on the subjects of both slavery and blackness. In 2016, maintaining this narrative during a Democratic National Convention in Philadelphia, Michelle Obama replied to the idea promoted by the Donald Trump presidential campaign that America needed to 'become great again' (Waxman, 2016), where she gave a striking example of autobiographical ethnicity on how their journey, as an African American family, and in particular her two daughters, demonstrated how America, for some ... 'was already great':

That is the story of this country, the story that has brought me to this stage tonight, the story of generations of people who felt the lash of bondage, the shame of servitude, the sting of segregation, but who kept on striving and hoping and doing what needed to be done so that today I wake up every morning in a house that was built by slaves. And I watch my daughters, two beautiful, intelligent, black young women playing with their dogs on the White House lawn.

(Michelle Obama, cited in Waxman, 2016)

For those unaware, when construction on the White House began in 1792, the labour force was made up of black slaves, and in addition, indentured white slaves from, yes, you guessed it ... Ireland. Michelle Obama, through her own example of autobiographical ethnicity, suggests, no she insists, that rather than exit a history we were never written into we should instead rewrite our 
own history and glorify our endurance, our strength, our heroes and our own survival as achievement. Black is beautiful, black is strength and black is who we are and, yes, before we were invaded, taken from our homelands and spread around the world as slaves, we were all Aboriginal. Why should we cut our ties to history just to become accepted by our oppressor? It is in being able to look back through history, with integrity and faith, knowing that you have endured in truth that separates us from white cultures ... cultures that have no religion, faith or belief of their own. They have taken everything they possess, stolen from others, in demonstrating their fragility, scared of having their past exposed. It is they, not us, who benefit in our forgetting we were slaves, ripped from our homes; it is they who benefit from our forgetting the massacres and no longer remaining connected to the past. Why else would they be so insistent we all move on ...? My cousin Michael Baker put it far more eloquently than I ever could, in a Facebook post:

The first people of this land don't need statues of our hero's we have mountains that remind us of our people. We don't need painted portraits we have rivers that flow with stories n dreaming. Our songs are filled with culture and the language of the land. So we don't need books. Our history our connections our hearts are true to this country.

(Baker, 2017)

Interestingly, rather than moving away from my own whiteness, such awakening rather than divide my identity only unites my expression of humanity as both black and white, but further expressed through my Aboriginality. What the post does is create narrative as an interplay between the sensibilities of narrator-character and audience in suggesting an alternative, non-essentialising, contemporary relationship to history and place. This is poetry in its purest form ... breathtaking in its simplicity but captures our Aboriginality better than anything I have personally ever written. Michael does not possess a $\mathrm{PhD}$ in creative writing, does not share my agency within the Whiteman's academy, but is a known ceremonial dancer and teacher of our culture, having travelled the world. He is simply intuitive in sharing his worldview, as Kamilaroi, with the rest of the world just as he does in traditional dance, storytelling and performance ... It's quite beautiful and most importantly it is real. What I am trying to say is that acceptance/reality and truth do not segregate people and races. It's the denial of truth that maintains the separation. In taking on such a task in wanting to bring people together through truth rather than deception, autobiographical ethnicity became my medium in telling my own story. As a person of mixed race representing both the colonizer and the colonised, autobiographical ethnicity brings my life experience together - it includes actual historical characters and real stories as critical moments throughout my life inspiring a narrative, one that contains critical examination as explanations of historical persons and constructions in building my own reality out of the chaos. It started unconsciously when people would ask me how I ended 
up in New Zealand with an Aboriginal mother. The truth is I didn't know, how could I ...? I was a baby, I couldn't possibly remember. As I got older I had loved ones (this was long after returning to my Aboriginal mother) tell me different stories on both sides - people I loved but extreme polar opposites from one another, from black, to white to privileged to poverty all sharing their own stories about what had happened - from 'your Aboriginal mother never wanted you, she wouldn't even hold you as a baby, we gave her money and sent her home, you were our little chocolate wish from heaven' on one side to the extreme opposite on the other ...'we were never told, yah mother was told you were stillborn, broke her heart when you came home ...' What was I meant to do ...? So I did the only thing I could do, out of the 11, 12 different stories I was told by different people I love, I made up the ONE story out of the 12 that made sense to me, kept me sane. I guess I was born a storyteller. ... This is how, based on Aboriginal and non-Aboriginal historical and contemporary interactions, I utilise autobiographical ethnicity to draw upon my own lived experience in creating my own reality: my writing then becomes witness as a metaphor for my generation as part of the Stolen Generation; our collective frustration becomes my own in opposition to the obstacles placed in front of me. It is through this interface of barrier construction as implied by race within both a historical and contemporary context, that this book represents the possibility for a brighter future, no matter how traumatic in accepting our past. 


\section{Waaran (Conclusion ...)}

We can no longer assume, if we were fortunate enough to live in one of the 'developed' countries, that our way of life represents the most advanced strand of progress and that other societies have simply been less successful than ours in attaining it. Instead we now know that other societies have made other choices, followed different paths in search of different destinies. This knowledge opens up new vistas on the richness and variety of what it means to be human.

(Maybury-Lewis, 1992, p.202)

Everything I write is an experiment in thought and practicality in wanting to first and foremost negotiate my own healing process. I remain undecided on how good or successful that journey has been ... what I do know is that I have begun, and look forward to journey's end in what I refer to as one day relaxing in 'the summer of my life' free of trauma. It began with a conscious decision to first emancipate myself mentally, no longer accepting that I am part of the oppressed (thank you Marcus Garvey and Bob Marley) ... and returning to key philosophies embedded in our Kamilaroi Aboriginal First Nation epistemologies (knowledges ...) our winanga-li before the arrival of the 'Whiteman'. My healing is then based first on my personal journey shared as a reinvestigation of my Aboriginal identity as a practical response in how I choose to live my life today - not as a victim but as a survivor who remains a strong black Aboriginal and connected to my land. I remove myself from bondage in taking ownership of myself, my past, my present and my future in moving towards a provisional hypothetical space running parallel in its authenticity for both the coloniser and the colonised - black and white, Aboriginal and non-Aboriginal, inherent within my own consciousness. In telling my own story as a witness to what I have seen and experienced within a scholarly approach, my writing offers autobiographical ethnicity as an obvious link towards this third space in replacing a void within the humanities which currently 'does not adopt a generic research strategy' in raising epistemological issues (Bell, 2006, p.85). I understand that in establishing such creative practice-led research through its very 'source', my own observation, 
reflection and life experience, I tread a fine line 'between demonstrating our capacity to engage the discourses of other disciplines (in order to make our case more easily understood), and actually distorting the most powerful characteristics of our field' (Wissler, 1997, p.88). I remain aware that this third space lies 'between the generative act that brings a work into existence and the receptive act that is a proper appreciation of that work' (Davies, 2004, p.26). Autobiographical ethnicity evolving from a motivation to uncover the resonance of my blackness, but also in generating from within this third space a reservoir of knowledge recognising the Aboriginal voice currently untapped within the humanities - as an institution deprived within its own whiteness. In developing autobiographical ethnicity I have outlined the following steps in opening up this traditional Aboriginal knowledge space contained prior to colonisation or invasion within parallel histories presently denied in Western education.

Step 1. In order to remove the binary relationship of hierarchy and opposition evident in current relationships between black and white, Aboriginal and non-Aboriginal knowledge production, we must first address that definitive point which constitutes Aboriginal pedagogy in re-establishing our blackness to the very origins of our creation. To define our pedagogy in such a way that it was cognitively inherent to all that is Aboriginal and/or black in relationship within its own epistemology, retained as parallel, equal to and even superior to non-Aboriginal or white knowledge production. My strategy to overcome the current ambiguity of what constitutes our own epistemology (and, by implication, my very identity) is self-evident in storytelling and sharing as autobiographical rhetorical construction independent from the white institution via autobiographical ethnicity in telling our own stories, our way:

a self for public, not private, purposes: the displayed self is a strategically fabricated performance, one which stages a useful identity, an identity which can be put to work. It is the quality of that usefulness which determines the politics of autobiographical discourse. In other words, what is the identity being put forward for?

(Ang, 2001, p.24)

Step 2. Establish a new interdisciplinary approach that gives recognition to parallel Aboriginal and black traditional epistemologies embedded in conversation and observation throughout history which is both non-linear and circular in its narrative that captures both the black and white, Aboriginal and non-Aboriginal histories as equal and running parallel to each other:

If you hear the dogs, keep going. If you see the torches in the woods, keep going. If there's shouting after you, keep going. Don't ever stop. Keep going. If you want a taste of freedom, keep going.

(Tubman, in Komolafe, 2010, p.122) 
As we open the crucible of our own blackness, our Aboriginal knowledge base having been denied for so long becomes so complex and multi-layered that meaning evolves and changes on almost a daily basis (as new understandings became clearer). We open our mind in allowing a transfer of ideas as a 'creative hypothesis' beyond conventional time and space, beyond whiteness and Western teaching: Kamilaroi epistemology does not obey the laws of history and science as promoted in the institution. These shifts away from predictable academic methodology are needed to move successfully across current barriers of boundary construction, both Aboriginal and nonAboriginal, black and white. In order to appreciate our humanity on such an enlightened level we must then become interdisciplinary and multi-layered, even existential in our approach - such understanding remains vital in disrupting the binary of racism and history that has previously held us back dominated by whiteness.

Step 3. Argue the case for securing the position of a new, equal, perhaps even superior position away from white knowledge production for black and Aboriginal epistemologies to flourish. The space-time continuum relevance to the Aboriginal worldview recognised by Maybury-Lewis (1992) supports the idea of equality, even superiority of Aboriginal epistemologies. In his study of Aboriginal peoples Maybury-Lewis alludes to the impossibility of many nonAboriginal people ever comprehending Aboriginal knowledge systems, once the discussion has moved beyond the binary of colonisation, racism and oppression. This is due to Maybury-Lewis stating it is only within quantum theory where the material world becomes open to the Aboriginal worldview inscribed on its basic elements of indeterminacy, uncertainty and other characteristics that outside Western science would be described as spiritual. It is here that quantum theory meets Aboriginal epistemology with its catalogue of morphing, transforming forces based deep in the structure of the matter that constitutes a once-traditional Aboriginal knowledge base.

What the physicists did not know, or at any rate did not mention, is that the ideas contained in quantum theory have interesting similarities to the worldview of Australian Aborigines, right down to the space-time continuum of relativity theory.

(Maybury-Lewis, 1992, p.198)

This gap between knowledge base systems unfortunately will not close anytime soon as education agendas continue to dismiss Aboriginal epistemologies, in seeking to render both schools and students uniform within Western values of belonging (McKinley, 1996). Science education fails to accept students' cultural understandings, especially if they depart from the principles of current science knowledge, one that excludes Aboriginal languages, our worldview and/or our strategies of learning (Wood \& Lewthwaite, 2008). By not valuing, teaching or including 'other' ways of understanding the world and their technologies, Western education fails to acknowledge the 


\section{Waaran}

gamil-bidiwii: a time before the beginning, not only prior to students entering their classrooms, but essential to the deep local knowledge, values and beliefs of not only Aboriginal and black students, but all other students who enter their classrooms. 


\section{Waaran garaay (Final word ...)}

I was talking to my boys about Budjaar, our Creator, and how much love comes from everything given to us through creation, and my 16-year-old son said to me ... 'I been thinking lately... you realise worms are more important to the earth than we are. If all the worms or bees or green frogs were destroyed there would be devastation to the eco-system, the planet may not even recover because they are all so important to life ... if man was destroyed the planet would flourish and repair itself ...' I just looked at him in amazement ... he was right. There was a time when we played our role, even managing the environment though we are seen as primitive because we never built massive skyscrapers or monuments to ourselves - but through eco-land management, biodiversity and cohabitation our lands flourished ... a time when we truly had domain over all things and yes, were just as, if not more, important than the worms, bees and green frogs. I have mentioned throughout the book the way the greater majority of non-Aboriginal Australians, and therefore the world, still have no idea of these advancements, innovations in science, eco-farming and organisational structures we possessed. What I haven't mentioned is another major division propagated by the belief that we receive millions of dollars in entitlements purely based on our being Aboriginal, which like our untold history creates division and hate. Most comments you see on Aboriginal threads by white Australians posted on social media are either based on our being primitive savages, or benefiting from such entitlements, both of which are not true. My son didn't just say what he did, he doesn't live in a vacuum, it comes from his being part of collective ceremony and culture since he was a little child. It comes from his having to collect sandalwood and ochre prior to ceremony and being told the importance of kinship systems and how the sandalwood and ochre tie into the land. In having the ochre crushed up into a powder with water from the Macintyre River creating the paste worn on his body. Being told of the importance of the Gawuban Gunigal (water systems ...) connected across Australia as Kubbaanjhaan (bloodlines ...) within the landscape sustaining life and ecology. Suddenly current debate about memorials and dates of significance for me went far beyond any history wars ... in listening to my son I remembered the Facebook post from my cousin on 27 August 2017: 
The first people of this land don't need statues of our hero's we have mountains that remind us of our people. We don't need painted portraits we have rivers that flow with stories $n$ dreaming. Our songs are filled with culture $\mathrm{n}$ language of the land. So we don't need books. Our history our connections our hearts are true to this country.

(Baker, 2017)

I had a light bulb moment realising the effect on all those millions of kids around the world who are never introduced to an Aboriginal education the way my children have been. This conversation, again with my boys, and the above post from my cousin, reaffirmed everything I have been trying to say in writing this book, better than I ever could. That without such involvement, denied access to Aboriginal pedagogy, these kids growing up in the Western world, rather than becoming sophisticated, as we are told, instead are lacking in the most basic knowledge of self and their connection to the environment. And how these children denied input from Aboriginal knowledges and sustainability become instead active contributors in generating environmental wastelands (Monbiot, 2012). This is because instead of the worldview so inherent to my son, they accept without question the dominant culture's dependency on/addiction to fossil fuels, as entitlement, which to us as Aboriginal people along with commercialisation remains part of environmental terrorism generation upon generation. Not only environmental terrorism and commercialism, but also bordering on cultural genocide; why? ... Because it is done at the expense of renewable energies, biodiversity, cohabitation and our Aboriginal ways of life. The conservatives, our own people included, have tried to silence such views by proclaiming, rather than an Aboriginal connection to the environment, we are only following the greens and the left as puppets controlling our voice. No ... sustainability and environmental issues have always been essential to the Aboriginal worldview.

Tony McAvoy, one of Australia's leading native title lawyers, has spoken publicly as a traditional owner, about the 'proud and independent people' fighting to stop coal mining in Queensland, dismissing claims by Aboriginal conservatives such as Marcia Langton and Warren Mundine that our mob are instead 'collateral damage' via an 'environmental industry' hijacking Aboriginal issues. McAvoy went as far as to say that such claims are 'false, disrespectful' and 'wildly off the mark' (Robertson, 2017b). Now more than ever Aboriginal people have to reconnect to environmental issues as essential in understanding who we are and what we represent, not only here in Australia but across the world. It's no longer just a question of our identity, but literally our survival. In 2017 we witnessed Donald Trump as the US President pulling out of the Paris Climate Agreement. The United States, together with China, Russia, Japan, India and the European Union countries contribute over half of global greenhouse gas emissions, more than every other nation in the world combined (BP, 2016). In taking office Trump also approved the Dakota Keystone XL Pipeline by executive order. The pipeline 
had become a symbol of the environmental Aboriginal struggle across the world. Evidence-based research from Environmental Canada states that the pipeline will increase energy dependence on fossil fuel with production projected to double by 2030 (Tankersley, 2017). The Dakota Pipeline protests became known by the hashtag \#NoDAPL as part of agentive action occurring simultaneously across the world. At the same time here in Australia organised resistance by Aboriginal people was created via social media through \#SOSBlakAustralia, and in the United States as we saw the emergence of \#BlackLivesMatter, creating a fusion of black and Aboriginal identity as grassroots movements - exposing white fragility for all its hostility towards people of colour who dared speak for themselves. Our resistance formed not only against open violence towards us but also in wanting to save the environment where both our blackness and Aboriginality become one. Trump's position amounts to nothing more than a false hope ... built like that of Australia on a pioneering myth from the past and taking advantage of lowly educated whites who believe in their superiority and entitlement. In their ignorance they continue to put at risk some of the poorest people in the world. As more carbon accumulates in the atmosphere, and global average temperatures continue to rise, the odds of catastrophic future environmental outcomes increase dramatically. I remember as a child returning from St George, western Queensland, our traditional homelands, and my mother had discovered we had taken rocks from a ceremonial ground. She put them up safe on top of a cupboard and covered them in Euraba leaves and sandalwood, both plants used in ceremony for healing, and then made us take them back to the exact spot when we returned to St George three months later ... she was so angry. That's not native romanticism, that's maintaining country and keeping things in place ... keeping balance in what we refer to as singing the land. After I posted what my son had said about worms, bees and green frogs on social media, one of my childhood friends I haven't seen for years replied:

Gungu Bama: 13 September at 13:20 ... Country needs ceremony. Ceremony needs country. If frog dies his song and dance dies with him. We must keep the corroboree going. Sing and dance for frog. Yawu [Yes] sing and dance for frog, for land and for family. Wiirrngaa nginda dhargan (love you brotha ...).

I am writing this passage just after the most powerful Atlantic Ocean storm in recorded history, Hurricane Irma, swept across the Caribbean leaving destruction in its wake, smashing into Puerto Rico and destroying several smaller islands on a collision course with Florida where I have a colleague and friend, Dr Marva McClean, who lives in Miami. Marva, who is Jamaican of African descent, closely associated with the Maroons, spoke to me shortly after the hurricane had passed. She described the fallen trees, the debris left behind, but conscious that Florida did not suffer the full brunt of 


\section{Waaran garaay}

the hurricane. Again as an Aboriginal person associated with the Maroons she commented how she felt flat, exhausted in connection with mother earth. We spoke of the most basic principle of our Aboriginality in our seeing our world as a living organism, and that the hurricane and other devastation we are currently witnessing is this organism fighting back from being destroyed by predators. Not only warning us of her immense power, but also in allowing us a small glimpse into her pain as our earth mother. She is dying slowly and it is imperative that we hear her cries for help ... could you imagine the full devastation if rather than the periphery Florida was to feel the full power of the storm - it is just a matter of time, said Marva.

What we also noted together was that in all the articles written glorifying and hyping up the storm, none were written from this Aboriginal perspective so ignorant and displaced are those in the West. As Aboriginal people we continue to shake our heads - surely people can see that it is the same people opposed to truth telling in history who are also denying the impact of greenhouse emissions on our environment, those imposing ruthless neoliberal austerity politics against welfare and spreading hate and fear against the most vulnerable people in the world? When we see all the evidence around us it appears only to be race that is getting in the way as people of colour simply cannot be trusted and no matter what their leaders do, white people keep putting them in power. Yes, we had a black President of the United States, a Muslim Mayor of London and an Asian Mayor of Melbourne in Australia, but they never last long, another never follows them and the spread of white fragility and hostility since is evident for all to see. But as stated, this is not only about politics and critical race theory; more importantly, it is about survival and our ongoing sustainability on a planet we are slowly killing despite all the evidence around us. In Australia our Torres Strait Islander brothas and sistas whose traditional lands are on scattered islands between Papua New Guinea and the top of the Australian mainland in far north Queensland have noted the rising sea levels are literally drowning their future lands away, and yet Australia remains as addicted to fossil fuels as ever. The World Bank (2015) in a recent report estimates climate effects could push 100 million people worldwide into poverty over the next 15 years.

'It is a decision made for domestic political purposes that puts the livelihood and lives of millions of people in developing countries at risk', says Trevor Houser, a former climate negotiator for President Barack Obama who is now a partner with the Rhodium Group. 'This is a craven, symbolic political move without any direct benefits for the constituents he's targeting.'

(Tankersley, 2017)

The Climate Impact Lab (Burke et al., 2015) forecasts that the most damaging effects for those 100 million people will be concentrated in, yes, you guessed it ... Aboriginal communities across the world. But both reports also 
provide solutions. These solutions prioritise poverty reduction and development work while taking into account a changing climate. It also means taking targeted action to help people cope with climate shocks in developing early warning systems and flood protection, and in the introduction of heatresistant crops. At the same time, efforts to reduce emissions should accelerate, and be designed to protect the poor (Hallegatte et al., 2015).

We have the ability to end extreme poverty even in the face of climate change, but to succeed, climate considerations will need to be integrated into development work. And we will need to act fast, because as climate impacts increase, so will the difficulty and cost of eradicating poverty.

(John Roome, Senior Director for Climate Change at the World Bank Group)

Unfortunately what we witness in both Australia with the Torres Strait Islands, and also with Hurricane Irma devastating the Caribbean islands, is the exact opposite: where the Torres Strait Islanders, despite being Australian citizens, have been sold out to an economy dependent on fossil fuel production, and the Caribbean, despite being British colonies, are nothing more than tax havens to the wealthy ... well, the locals live in absolute poverty with very little to no protection from natural disaster.

As one who spent more than 30 years across the Caribbean I can assert that the insecure wooden dwellings, shops and churches belong to poor black people and that the wealthy (and virtually all of the white population) will dwell in the more secure concrete block structures. This is a social disaster created not by hurricanes but by history, with Britain and its empire making that history in the Caribbean. Yes, there were, indeed are, others complicit in this tragic history but in the context of Anguilla, the British Virgin Islands, and Turks and Caicos, Britain has direct responsibility while, with Antigua, Barbuda, and the Bahamas, Britain has historical responsibilities.

(Cross, 2017)

As Kamilaroi I have experienced a metaphysical relationship within the environment a number of times, so my conversation with Dr Marva McClean about Hurricane Irma and the world as a living organism made perfect sense to me. My most powerful and emotional experience occurred back in September 2009 when I returned to our traditional homelands in Moree in northern New South Wales with my family. We had been called home for ceremony after the Apology to Aboriginal People by the then Prime Minister Kevin Rudd for the Stolen Generations, to continue a healing process that had begun with a gathering in Brisbane. Due to the Kamilaroi being renowned as stomp dancers, where we stomp into the ground kicking up the dust around us rather than shake-a-leg, as seen throughout other Aboriginal 
nations of Australia, we often say to the kids learning their traditional dance/ corroboree 'Kick up Dust'. Therefore, like many other Kamilaroi people who were attending the ceremony/festival, I told many of my Aboriginal and nonAboriginal colleagues alike prior to us going that we were going to 'Kick up Dust' like never seen before ... we all did! We returned home to Moree on Tuesday, 21 September and together with my family and over 100 other Kamilaroi, Gamilaroi, Gamilaraay families held a traditional Gamilaraay winnunguulda yammaa yilugi (welcome to country) ceremony that lasted well into the night. I will never ever forget being woken up the next morning by my gaayangals (children ...), my 16 year old who was only eight years back then, and my other boy who is now 15 years old was only six, and my daughter now 21 years old was only 14, and they were screaming ... 'Bubah ... Bunah ... ngaami-li minya ngiyania ganunga!' (Daddy ... look what we did!). They had woken me to one of the biggest dust storms ever seen on the east coast of Australia. It dropped literally '75,000 tons of red dust [in] an hour', covering from Mt Isa, their mother's traditional country, right down to Canberra, the nation's capital.

Dust from the interior would make it about $3500 \mathrm{~km}$ to New Zealand [where I was reared] while material crossing Queensland and the northern NSW [where I had just gathered with my Kamilaroi, Gamilaroi, Gamilaraay family] would be recycled north in one to two days with the potential to reach as far as Darwin [where I had just returned from a flight from Ramingining across the other side of the country] ...

(Courier Mail, 2009, p.3, with my insertions)

At that point I found myself in a unique opportunity of choice ... where this was either purely coincidence, simply being in the right place at the right time, or we had orchestrated something significant in shaping the landscape ... so as a Kamilaroi father I did the only thing I could do in that situation, I looked my gaayangals in the eyes and told them: 'Bigirrma-li warra-y yuu gayaangal-li! (Blood and guts, look what we did. Kick up dust, kids!) ... we are the mighty Kamilaroi ...' And that's what we continued to do over the next three days ... kick up dust!

Maintaining such a balance with biodiversity as in our relationship to the land is the very premise of Aboriginal First Nations belief systems. The obvious devastation to the world in having our voice silenced is there for us all to see, not only through violence and hostility but also in having our history erased and via cultural appropriation in becoming romanticised and denied our traditional practice. The binaries created by the powerful relationships between neoliberalism, consumerism, power and privilege via Western education have influenced all epistemologies where what were once profound statements of environmental sustainability have become nothing more than romantic posters sold at markets around the world with accompanying images of noble natives in headdress - placed above bars in man 
caves across the Western world. Nothing makes this statement clearer than the Native Turtle Island saying: 'When all the trees have been cut down, when all the animals have been hunted, when all the waters are polluted, when all the air is unsafe to breathe, only then will you discover you cannot eat money' (Obomsawin, cited in Poole, 1972, p.39).

It is a situation that reminds me of a conversation I had with my grandfather when I was a young fella ... I was only 17 and Pop (my grandfather) walked into our kitchen and he could see that something was wrong, 'Marcus ... you look troubled, I think you need to take time off school', he said. I explained to my grandfather that over the next couple of weeks I was to sit my senior exams - and that this was the most important time of my life. 'The most important time of your life?' Pop replied. 'You're 17 ... you haven't even made love to a woman yet ... held a child in your arms as it falls asleep or worked for a living ... and the next few weeks are the most important few weeks of your life?' I had no idea of pedagogy, ontology or epistemology back then, only that Pop used to always go into these stories or parables when he wanted to teach me something. I couldn't see then how narrative and storytelling related to ongoing cultural maintenance and meaning - what I now understand to be a system of ontology performed as autobiographical ethnicity where some stories resonate, but don't offer true meaning until one is much older - a Kamilaroi Aboriginal knowledge base that I now recognise is used as a rite of passage in becoming a young adult or gulumaldhaay dependent upon life experience and understanding. My grandfather patiently let me finish and then continued ... 'It's like this boy ... the Whiteman forces you to think about so many things which just aren't that important ... so much so that you forget what really is important!' Pop could see I wasn't getting it ... That's when he said it, words of wisdom that I will remember for the rest of my life ... 'Understanding gravity doesn't make an apple taste any nicer ... it still falls from the bloody tree ...' A light bulb went off now, connected to when Uncle Reg tried to explain to me about time and consciousness where I had absolutely no idea, and years later when my son talked about worms, bees and green frogs being so much more important than man. I didn't know or fully appreciate at the time what my grandfather had just said to me ... but I knew it was profound (Waters, 2011, pp.395-396). There are so many stories to share that make this same point. Another one which has become a romantic notion, through a process of cultural appropriation turned into children's nursery rhymes, is that of the Rainbow Serpent ... again as it was told to me:

You know what he was boy ay boy the Rainbow Serpent them whitefellas call him ... we call him Mundugutta. That snake, he the same snake you see them China man you know when they dance them Māori call him Taniwha and in Africa he went everywhere even comes to Eve in the Garden of Eden. He came to us in his most primitive form, as a big massive worm that slithered across the lands creating life from nothing. 
You know what a worm does boy ... you live out in the suburbs where there no live just grass mowed to the fence like a carpet nothing growing there ... well you throw your peelings and old vegetables and fruit in that corner and then throw a handful of worms and stop mowing in that spot and you watch life come from nothing. Before you know it within a few weeks you will hear it before you see it ... life, the insects and things slithering and moving in that corner where there used to be nothing now overflowing with life ... that Rainbow Serpent was a massive big worm, the biggest we have ever seen, and then it coiled itself into the bowels of the earth. They don't ever wanna wake that serpent up son ... no way ... cause its job is to give life from nothing ... all these big Whiteman cities and their destruction will be turned down in an instant ...

(Spearim, 2012)

Despite their academic credentials as leading Aboriginal Australian scholars, Nakata and Moreton-Robinson agree on the importance of such stories. Nakata asserted that while the scholarly concerns of Indigenous academics are not only 'diverse and scattered across the disciplines', they must always 'remain articulated to community concerns and sensibilities' as an essential means to 're-establishing continuities with former traditions and knowledge' (Nakata, 2002). Whereas Moreton-Robinson, as both a feminist and an Aboriginal academic, identified that the 'fluidity' of relations of power between researched and researcher were 'not complicated by Blackness' but rather by 'Whiteness', which served to 'normalise and situate both the researcher and the researched through their race privilege' (Moreton-Robinson, 2003 b). Both are important points of reference as what remains absent from the current literature on the relationship between Australia's past as a racist state, one embedded in the 'white Australia' policy and the 'Stolen Generation', is any consideration of how this relationship with racism evolves over time, not within Aboriginal stories and knowledge, we don't ever deviate from the truth. What is not being studied is the more long-term impact of such denial of biographical issues connected to the cultural sensibilities, within white Australian identity, peer groups and political systems. We should be studying white people and telling them what to do, not the other way around. And finally, please consider this almost my last story when you see hostility displayed over memorials commemorating mass murderers and genocide by whites over black people.

Twenty-six years earlier my Uncle Bob Weatherall won a landmark court case to bring ancestral remains home. By remains I mean skeletons, bones and fragments collected of our ancestors where there was once a very lucrative trade in the bones of our dead. The remains were only returned home three years ago. The reason for the delay ...? Government bureaucracy, university intervention, resistance from institutional and private collections (yes, private collections) and every tactic imaginable applied to stall the process. Having finally had the remains returned we had to first identify who within our mob 
still had knowledge of traditional governance and burial rights. In identifying these key roles we had to go back six generations to a Kamilaroi woman named Amelia Wightman, my great great grandmother. She was born in the Burruguu-ngayi-li (Dreaming) back in the 1870s when we could still remember the noise of children laughing, the women and men calling them in, the sound of ceremony, as told before ... the impending silence broken by colonisation. Throughout her life she witnessed our people begin to sneeze, their eyes going red before dying as influenza and smallpox took its toll in the hundreds of thousands. She survived the water being poisoned and our people being shot and hunted down. It was through her bloodline that our ceremonial leaders came. Uncle Paul and Auntie Bronwyn Spearim, who like Uncle Bob was a direct descendant of this wonderful, strong, beautiful black Kamilaroi woman. Lack of money, our own 'Indigenous' bureaucrats ... and division within Native title through overlapping land claims and language groups all contributed to the many obstacles we had to overcome during the 18 months building up to the burial ceremony. It is important to stress to all readers that we ensured that all aspects of traditional ceremony were carried out properly before handling the remains - sandalwood ochre chosen from particular areas of country representing our Maran Dhinabarra (ancestral beings) to protect those involved emotionally and spiritually. DNA testing was also carried out to ensure those buried returned to the rightful home. Burial poles and body paint symbols were used that haven't been seen for over 80 years, carried down by family bloodlines paying respect to traditional Yanguru (Moiety) and Yarudhagaa (Totem) kinship systems. The songs and dances also in accordance with traditional ceremony, some of which, like the carved symbols and body paint, had not been seen for close to 80 years.

None of these processes, though, could prepare us for what was to follow. As the men and women separated the night before to prepare the graves for burial, we said our goodbyes knowing that when we saw each other at dawn the next morning our lives would be changed forever. With all the preparations finished it was time to wrap the remains in the tea tree bark prepared by the women. As Aboriginal men we all just stared at each other - this was all becoming too real. Uncle Bob Weatherall then rallied our warriors with a stirring and heartfelt speech about meeting our customary rights and cultural obligation as Kamilaroi men. Uncle Paul Spearim then talked about dismissing the Christian fear of the dead that had been installed in us as kids on the missions - the idea that our cultural practices were entrenched in black magic and superstition. It was time to reclaim our cultural inheritance. My Uncle Ron Waters stood up, looked us all in the eye, clapped his hands together and then said, 'let's do this ...' and we started going through the remains in preparation for burial.

They were in concealed wooden boxes that had to be forced open revealing the horrors contained inside. We worked until we were exhausted and then others would take over. It was a team effort, as was the whole ceremony over the 18 months ... it had to be. What we experienced was too traumatic for 
any individual to carry. The first box was ribs and tibia bones. Deep breaths and then you just do what you have to do. The second box contained a skull sitting on top ... my uncle and I froze and he asked me if I was OK. I nodded and we did what we had to do. With each of the remains we would talk to the old people in Kamilaroi, telling them in soft, loving tones we were family, their great great grandchildren and we loved them dearly and we were now laying them to rest. As we laid each one down after wrapping them in the tea tree bark, my cousin and Uncle Paul Spearim's boy Peter Skuthorpe-Spearim would say a Kamilaroi prayer, again in language to guide them home and comfort them.

The most disturbing image for me personally was that some of the skeletons mixed together had been placed in a potato sack ... yes, a potato sack. We deliberated whether or not someone should document the image and in the end decided not to. The discussions were based around understanding and acknowledging the horror our people went through, more as a process of healing rather than continuing a legacy of pain. If our old people were forced to endure such tragedy then could we summon the strength to view such an image out of respect and do what we had to do to finally put them to rest ... I guess this is why I finish the book, or should I say almost finish the book, with this experience. To pay homage and write my own memorial to what happened, and I make no apologies. We have all seen images of the 'Shoah', the Jewish Holocaust. These images were meant to ensure that atrocities of this nature should never occur again, but, as we know, they continue, over and over again. In the time that I have taken to write this book over the last three and a half years we have been witness to genocide occurring in Syria, West Papua, and as I write this final passage, news is breaking of ethnic cleansing in Burma of the Rohingya Muslim population. This is the problem with a white race claiming what is effectively a moral monopoly over the use of the words genocide and holocaust ... the white world then turns a blind eye as such atrocities continue against brown- and black-skinned people across the world. As cited earlier in the book from Inga Clendinnen:

I am reasonably sophisticated in these modes of intellectual discussion, but when I see the word 'genocide' I still see Gypsies and Jews being herded into trains, into pits, into ravines, and behind them shadowy figures of Armenian women and children being marched into the desert by armed men. I see deliberate mass murder.

(Clendinnen, in Lawson, 2014, p.16)

These genocides continue over and over, against people of colour, people in the world, as those privileged in the West use the greatest communication tool ever devised in history, social media, not to raise alarm but instead to Instagram to one another the meals they eat and to share inane gossip about celebrities - as black and brown bodies not only denied in history but today continue to pile up in the killing fields, as military and civilian killings 'are 
gathering dead bodies and burning them so [as] not to leave any evidence' (Agerholm, 2017).

I understand why people struggle with the existence of God, though my own faith is strong, but how anyone can deny the existence of a devil is beyond me ... Images from the repatriation ceremony haunt me to this day ... A skull that had been cut in four equal pieces. A complete family were buried together each with bullet holes in their skulls. A skull had been crushed and was accompanied with a handwritten note from a police officer explaining the 'Aboriginal Full Blood had died in custody'. In the end ... the images I will draw upon in the future are not from the night we wrapped our ancestors, though they will remain deep in my subconscious for years to come, but instead the healing that took place. Adults would came back and forth from the ceremony grounds where there were children waiting on the periphery wanting to learn the dances, speak their language and hear our stories. No children were allowed anywhere near the burial site itself. The younger men and women who did attend the burial were all put through processes of initiation and ceremony which they would then lead in dance as well as teach the language to the young ones when returning. There was a multi-generational production line of cultural maintenance and teaching that occurred over the three weeks. It was inspirational and uplifting. Not only for us but the many non-Aboriginal people who witnessed these events from the local towns, who came to pay their respects, but like the children were not allowed anywhere near the burial site itself. This is where our future lay in dealing with our past, acceptance, teaching, and strength in reclaiming our cultural identity and in being allowed to mourn and take our rightful place in the world with the support of non-Aboriginal people who paid their respects.

\section{And finally ...}

In introducing autobiographical ethnicity as my methodology, my writing has taken directly from my life experience and allowed a unique sharing of time and space with you ... the reader. As I come to the very end of this, a three and a half-year journey, I once again find life imposing itself on my art, and my craft.

I am making final edits having received the proofread copy back from the publisher and as I sit in deep reflection I realise that once again my ancestors are with me as after three and a half years I find myself finishing the book the day before Australia Day, celebrated on 26 January, a day we Blackfellas refer to as either Survival or Invasion Day.

There is no question that for many of our mob, Australia Day, much like Columbus Day in the United States, generates enormous grief, anger and sorrow in marking the European invasion of our country. The date divides our nation as on 26 January Australians celebrate the erasing of tens of thousands of years of prior occupation, civilisation and all the complexities that come with the oldest living culture in the world - in honouring an 
invasion and the devastating effects that occurred as a form of genocide upon my people.

As I write this final passage, Andrea Bocelli's version of 'Time to Say Goodbye' with Sarah Brightman has started to play on my Spotify - considering that I have literally thousands of songs on my phone, another indication from my ancestors that it is time to put the past behind me in now completing the book.

Generations of misrepresentation within our education systems glorifying peaceful settlement and Europeans as a superior culture that brought with it civilisation have had a psychological effect on masses of people who refuse to accept the truth ... both black and white. Racism is not part of the human condition, it is taught. You are not born racist, you are born into a racist society ... you have to be taught to be a racist.

As I sit in isolation finishing my book, others choose to celebrate Australia Day and a history of colonialism continuing to regurgitate one of the great lies told throughout history. This is the great myth of colonisation as pioneers and great white explorers who ventured out and conquered the unknown in bringing civilisation to the primitive savages of the world.

In reflecting on Australia Day and in finishing the book, I went back home to spend time with family. While there, I was talking about the book, and the last three and a half years now coming to an end, with my cousin Samantha Bunda, the daughter of my Auntie Rose who was married to my uncle before he passed. Sam, as we call her, was telling me that her son Natty Boy had been learning about Aboriginal history in class, and why he didn't want to celebrate Australia Day at school. Things have changed since we were kids, we were both saying, but then Sam told me the story of her grandmother called Nan Nellie Bunda, aka Dalton, a Quandamooka First Nation Australian Aboriginal woman who was taken as part of the Stolen Generation. Nan Nellie Bunda's great great grandson, Sam's little Natty Boy, who was only nine years old, had recently asked to tell the class about his great great Nanna. Natty, just as his big cousin, my daughter, did, attends a Catholic school. Sam was so proud, 'yeah and the way he tells it', she said, as she turned and yelled out to him, 'Natty Boy come and tell Uncle Marky about Nanna Bunda and what you said at school ...' Well you could have blown me away. Natty came in real proud, his back straight and looked me in the eye ...

... Her hair was blowing in the wind, he said ... at Turbal Point beach having come out from hiding in the bush. She had no shoes on so they took her, which is all she remembers ... she was only five years old and they took her to Roma St and put her on a train to Purga where she was forced to live and worked as a slave ... Natty even included the name of one of the teachers who ran the dormitory his great great Nanna was forced to stay until Ms Woolie, that was the teacher's name, told Natty Boy's great great grandmother she had to leave Purga to work full time as a domestic slave ... she was only 14 years old, said Natty, who had heard 
the story from his grandmother and mum, and like me and so many others with our history and Myall Creek, this was now part of this young boy's consciousness. I wanted to share this story with my class so they know about my great great grandmother to help them understand me ... he said, and I wanted them to hear this story with both their ears and their jugu (understanding) a word spoken from the traditional language of Stradbroke Island where my family come from, he said, pointing to first his chest and then his head ... and that's why I don't celebrate Australia Day, Uncle.

(Natty Boy, in 2018)

I asked Natty Boy directly why this story was so important ... why he wanted to share it with his class when there were so many other stories that could have made them understand who he was and opened their hearts ... He looked at me like I should already know the answer ... like it was a silly question and said back to me ... and this is really why I wrote this book and I couldn't say it any better than this nine-year-old little boy from Stradbroke Island ... 'because it was my Nanna', he said. 


\section{References}

Adam, B. (1996). Detraditionalization and the certainty of uncertain futures. In: Heelas, P. (Ed.) Detraditionalization: Critical Reflections on Authority and Identity. Oxford: Blackwell, pp. 134-148.

Adkins, L. (2002). Revisions Gender and Sexuality in Late Modernity. Buckingham: Open University Press.

The Age. (2011). Andrew Bolt: Australia's least accurate columnist? The Age. Retrieved from: www.theage.com.au/victoria/andrew-bolt-australias-least-accura te-columnist-20111001-112zl.html.

Agerholm, H. (2017). Burma soldiers 'burning bodies of Rohingya Muslims' to conceal evidence: Buddhist civilians participating in mass killings, says campaigner. The Independent. Retrieved from: www.independent.co.uk/news/world/asia/burma-rohin gya-muslims-genocide-soldiers-burn-bodies-massacre-evidence-crackdown-minoritya7927981.html.

Ah Kee, V. (2006). Black Eye = Black Viewpoint: A Conversation with ProppaNOW. In: Machine. Brisbane: Artworkers Queensland Government, pp. 2-4.

Albrecht, G., Sartore, G.-M., Connor, L., Higginbotham, N., Freeman, S., Kelly, B., Stain, H., Tonna, A., \& Pollard, G. (2007). Solastalgia: The distress caused by environmental change. Australasian Psychiatry, 15, S95-S98.

Altman, J. (2013). Arguing the intervention. Journal of Indigenous Policy, 14, June. Retrieved from: http://caepr.anu.edu.au/sites/default/files/cck_staff_publication/2013/ 09/JIP14\%20low\%20rez.pdf.

Anderson, I. (2003). The Aboriginal critique of colonial knowing. In: Grossman, M. (coord. ed.) Blacklines: Contemporary Critical Writing by Indigenous Australians. Carlton, Vic.: Melbourne University Press, pp. 17-24.

Anderson, P. (2017). 1967 and Mabo - Moving Forward. Q \& A. The ABC, 29 May. Retrieved from: www.abc.net.au/tv/qanda/txt/s4655309.htm.

Ang, I. (2001). On Not Speaking Chinese: Living Between Asia and the West. New York: Routledge.

ANTAR. (2016). The Redfern Statement: An urgent call for a more just approach to Aboriginal and Torres Strait Islander affairs. Australians for Native Title and Reconciliation. Retrieved from: https://antar.org.au/campaigns/redfern-statement.

Anthony, T. (2004). Labour relations on northern cattle stations: Feudal exploitation and accommodation. The Drawing Board: An Australian Review of Public Affairs, 4(3), $117-136$ 
Apologia. (2016). In Merriam-Webster Collegiate Dictionary. Retrieved from: www2. merriam-webster.com/apps/apache/docs/cobrands/cgi-bin/mwdictsn?book=Dictiona ry\&va=apologia.

Armelagos, G.J., \& Cohen, M.N. (Eds) (1984). Paleopathology at the Origins of Agriculture. New York: Academic Press.

Attorney-General's Department. (2014). Royal Commission into Institutional Responses to Child Sexual Abuse. Commonwealth of Australia. Retrieved from: www. childabuseroyalcommission.gov.au/about-us/our-reports/vol-2-bookmarked_low-res.

Attwood, B. (1996). The past as future: Aborigines, Australia and the (dis)course of history. In: Attwood, B. (Ed.) In the Age of Mabo: History, Aborigines and Australia. Sydney: Allen \& Unwin.

Augoustinos, M., Tuffin, K., \& Rapley, M. (1999). Genocide or a failure to gel? Racism, history and nationalism in Australian talk. Discourse and Society, 10(3), 351-378.

Australian Bureau of Statistics. (2011). Census of Population and Housing: Characteristics of Aboriginal and Torres Strait Islander Australians (ABS Cat. No. 2076.0). Canberra: Commonwealth of Australia. Retrieved from: www.abs.gov.au/ausstats/a bs@.nsf/Latestproducts/2076.0Main\%20Features902011?opendocument\&tabname= Summary \&prodno $=2076.0 \&$ issue $=2011 \&$ num $=\&$ view $=$.

Australian Human Rights Commission. (2011). Lateral Violence in Aboriginal and Torres Strait Islander Communities - Social Justice Report. Australian Government. Retrieved from: www.humanrights.gov.au/publications/chapter-2-lateral-violence-a boriginal-and-torres-strait-islander-communities-social.

Australian Human Rights Commission. (2017). Legislation. Racial Discrimination Act 1975. Australian Human Rights Commission. Retrieved from: www.humanrights. gov.au/our-work/legal/legislation.

Australian War Memorial. (2017). War History: Colonial Period, 1788-1901. Retrieved from: www.awm.gov.au/atwar/colonial/.

Baker, M. (2017). Dhinawan Dreaming. Facebook post, 27 August at 06:16.

Bandicootcha, B. (2017). Ink dries on $\$ 600 \mathrm{~m}$ deal with China. National Indigenous Times. Retrieved from: http://nit.com.au/ink-dries-600m-deal-china/.

Barker, A. (2007). Aboriginal wellbeing levels not improving: Study. Australian Broadcasting Company, News. Retrieved from: www.abc.net.au/news/2007-12-21/a boriginal-wellbeing-levels-not-improving-study/994650.

Baumann, Z. (1999). The Multicultural Riddle: Rethinking National, Ethnic, and Religious Identities. London: Routledge.

BBC News. (2014). Maori king refuses Duke and Duchess of Cambridge meeting. BBC News. Retrieved from: www.bbc.com/news/uk-26435942.

Beckett, J. (Ed.) (1998). Past and Present: The Construction of Aboriginality. Camberra, ACT: Aboriginal Studies Press.

Bell, D. (2006). Creative film and media practice as research: In pursuit of that obscure object of knowledge. Journal of Media Practice, 7(2), November, 85-100.

Bell, E.S. (2008). Theories of Performance. Los Angeles, CA: Sage.

Bell, M. (2012). Interview with Marshall Bell. 10 January. Logan, QLD.

Bendall, C. (2017). We should take America's lead when it comes to Australia Day. news.com.au. Retrieved from: www.news.com.au/lifestyle/real-life/news-life/we-shou ld-take-americas-lead-when-it-comes-to-australia-day/news-story/0e4f4b50aa80a2d1 $8128 \mathrm{f} 61993 \mathrm{bc} 2238$. 
Berkes, F. (2012). Sacred Ecology: Traditional Ecological Knowledge and Resource Management. (3rd ed.) London: Taylor \& Francis.

Besson, L. (Director), \& Besson-Silla, V. (Producer) (2014). Lucy [Motion Picture]. United States/France: Universal Pictures \& EuropaCorp Distribution.

Beyondblue. (2014a). Campaign to address strong link between racism, and depression and anxiety in Indigenous Australians. Beyond Blue website. Retrieved from: www. beyondblue.org.au/connect-with-others/news/news/2014/07/29/campaign-to-addressstrong-link-between-racism-and-depression-and-anxiety-in-indigenous-australians.

Beyondblue. (2014b). Discrimination against Indigenous Australians: A snapshot of the views of non-Indigenous people aged 25-44. Beyond Blue Ltd. BL/1337 07/14.

Bhabha, H. (1994). The Location of Culture. London: Routledge.

Blanden, J., Gregg, P., \& Machin, S. (2005). Intergenerational mobility in Europe and North America. Report supported by the Sutton Trust, Centre for Economic Performance, London School of Economics.

Blum, E. (2005). 'There won't be any rich people in heaven': The black Christ, white hypocrisy, and the Gospel according to WEB Du Bois. The Journal of African American History, 90(4), 368-386.

Bohacek, J., \& Mansuy, I.M. (2015). Molecular insights into transgenerational nongenetic inheritance of acquired behaviours. Nature Reviews. Genetics, 16(11), 641.

Bolhuis, S. (2003). Towards process-oriented teaching for self-directed lifelong learning: A multidimensional perspective. Learning and Instruction, 13(3), 327-347.

Bolt, A. (2014). I am, you are, we are Australian. The Herald Sun. Retrieved from: www.couriermail.com.au/news/opinion/i-am-you-are-we-are-australian/news-story/ 63336ae43afb30a9fd04a2220b3d4cdc?sv=209a58e4c1188bac5e686df379654841.

Bolt, A. (2016). How activists use Aborigines to censor debate. The Herald Sun. Retrieved from: www.heraldsun.com.au/blogs/andrew-bolt/how-activists-use-abor igines-to-censor-debate/news-story/ae8f561c50ddd0c9cd6ac069d3681a21.

Bolt, A. (2017). Cultural Vandals Gaining Strength. The Herald Sun. Retrieved from: http://heraldsun.newspaperdirect.com/epaper/viewer.aspx.

Bourdieu, P. (1977). Outline of a Theory of Practice (Vol. 16). Cambridge: Cambridge University Press.

Bourke, E. (1998). Images and realities (2nd). In Bourke, C., Bourke, E., \& Edwards, B. (Eds) Aboriginal Australia. St. Lucia, QLD: University of Queensland Press, pp. 1-15.

Bowman, D. (2016). Did Aboriginal Australians hold the answer to our bushfire problem? Australian Geographic. Retrieved from: www.australiangeographic.com.au/ topics/science-environment/2016/02/aboriginal-bushfire-management.

Boylorn, R.M., \& Orbe, M. (2014). Critical Auto-ethnography: Intersecting Cultural Identities in Everyday Lives. California: Left Coast Press.

BP. (2016). BP Statistical Review of World Energy 2016. Retrieved from: www.bp.com/ en/global/corporate/energy-economics/statistical-review-of-world-energy.htmlCLIMA.

Brayboy, B.M.J. (2005). Toward a tribal critical race theory in education. The Urban Review, 37(5), 425-446.

Brewster, M. (2016). Giving this Country a Memory: Contemporary Aboriginal Voices of Australia. Cambria Australian Literature Series. New York: Cambria Press.

Brunton, R. (1992). Mabo and Oral Traditions. In: Durack, P., Rutherford, T., \& Brunton, R. (Eds) Mabo and After. Melbourne: Institute of Public Affairs, pp. 13-23.

Bultin, N.G. (1993). Economics and the Dreamtime: A Hypothetical History. Melbourne, Vic: Cambridge University Press. 
Burke, M., Hsiang, S.M., \& Miguel, E. (2015). Global non-linear effect of temperature on economic production. Nature, 527(7577), 235-239.

Burkitt, I. (2004). The time and space of everyday life. Cultural Studies, 18(2), 211-227.

Burrows, E. (2016). Revitalising indigenous resistance and dissent through online media. Journal of Media, Communication \& Film, 3(1), 90-108.

Calabrese Barton, A. (2001). Capitalism, Critical Pedagogy, and Urban Science Education: An Interview with Peter McLaren. Journal of Research in Science Teaching, 38, 847-859. Retrieved from: http://dx.doi.org/10.1002/tea.1035.

Chalmers, G. (2005). The Repercussions of Representation. In: Phillips, J., \& Lampert, J. (Eds) Introductory Indigenous Studies in Education. Sydney: Pearson PrenticeHall, pp. 151-165.

Christie, M. (1979). Aborigines in Colonial Victoria, 1835-1886. Sydney: Sydney University Press.

Clark, A. (2002). History in black and white: A critical analysis of the black armband debate. Journal of Australian Studies, 26(75), 1-11.

Clark, I.D., \& Kostanski, L.M. (2006). An Indigenous History of Stonnington: A Report to the City of Stonnington. City of Stonnington.

Clarke, A. (2016). Here's a Bunch of Things Pauline Hanson has Said About Indigenous Australians. BuzzFeed. Retrieved from: www.buzzfeed.com/allanclarke/pauli ne-hanson-and-indigenous-australia?utm_term=.sf1Qb0znv0\#.qyYva46jA4.

Clarkson, C., Jacobs, Z., Marwick, B., Fullagar, R., Wallis, L., Smith, M., ... \& Florin, S.A. (2017). Human occupation of northern Australia by 65,000 years ago. Nature, 547(7663), 306.

Cohen, M. (1977). The Food Crises in Pre-history: Overpopulation and the Origins of Agriculture. New Haven, CT: Yale University Press.

Collins, B. (2016). Alan Jones's stolen generation comments 'reopened wounds', says an Aboriginal leader. $A B C$ News. Retrieved from: www.abc.net.au/news/ 2016-02-16/alan-jones-comments-reopened-old-wounds-says-indigenous-leader/7173944.

Comic Vine. (2016). Fourth Wall: Concept. (The fourth wall appears in 610 issues.)

Cook, S. (2015). \#SOSBLAKAUSTRALIA: Stop the forced closure of Aboriginal communities - IndigenousX. The Guardian. Retrieved from: www.theguardian.com/ commentisfree/2015/apr/01/sosblakaustralia-stop-the-forced-closure-of-aboriginal-co mmunities-indigenousx.

Courier Mail. (2009). Day the Red Centre whipped into town. 24 September, 3.

Court, A. (2017). 'The Aborigines were reasonably well treated': Conservative commentator Prue MacSween clashes with Peter FitzSimons in a fiery debate over Captain Cook statue. Daily Mail Australia. Retrieved from: www.dailymail.co.uk/ tvshowbiz/article-4826818/Prue-MacSween-fiery-debate-Captain-Cook-statue.html.

Cowlishaw, G. (2004). Blackfellas, Whitefellas and the Hidden Injuries of Race. Melbourne: Blackwell.

Cox, E. (2014). Forrest report ignores what works and why in Indigenous policy. The Conversation. Retrieved from: https://theconversation.com/forrest-report-ignoreswhat-works-and-why-in-indigenous-policy-30080.

Cross, T. (2017). Britain has obligations to the devastated Caribbean that it must honour. The Herald. Retrieved from: www.pressreader.com/uk/theherald/20170912/ 282089161932731.

Cunningham, J., \& Baeza, J. (2005). An 'experiment' in Indigenous social policy: The rise and fall of Australia's Aboriginal and Torres Strait Islander Commission (ATSIC). Policy \& Politics, 33(3), July, 461-473(13). 
Cunningham, M. (2016). Ballarat men dress up in Aboriginal black face, accused of being racists. The Courier. Retrieved from: www.thecourier.com.au/story/3697973/ba llarat-men-dress-up-in-aboriginal-black-face-accused-of-being-racists/?cs=61.

Daley, P. (2014). Why the number of Indigenous deaths in the frontier wars matters. The Guardian. Retrieved from: www.theguardian.com/commentisfree/2014/jul/15/ why-the-number-of-indigenous-deaths-in-the-frontier-wars-matters.

David, P. (2002). Landscapes, Rock Art and the Dreaming: An Archaeology of Preunderstanding. London: University Press.

Davidson, H. (2015). Explainer: The facts behind the outrage over Tony Abbott's Indigenous 'lifestyle choice' remarks. The Guardian. Retrieved from: www.thegua rdian.com/australia-news/2015/mar/12/behind-the-outrage-over-tony-abbotts-indigen ous-lifestyle-choice-remarks.

Davidson, H. (2016). Indigenous MP ruled disorderly for speaking Warlpiri language in parliament. The Conversation. Retrieved from: www.theguardian.com/australia -news/2016/feb/18/indigenous-mp-ruled-disorderly-for-speaking-warlpiri-language-in -parliament.

Davies, D. (2004). Art as Performance. Oxford: Blackwell.

Davis, M. (2004). Great white noise. In Carter, D. (Ed.) The Ideas Market: An Alternative Take on Australia's Intellectual Life. Carlton, Vic.: Melbourne University Publishing, pp. 183-198.

Delmore Gallery. (2017). Kathleen Ngale (Kngale) Biography. Retrieved from: https:// delmoregallery.com.au/pages/kathleen-ngale.

Department of Education, Employment and Workplace Relations. (2010). Summary of the 2010 Higher Education Student Statistics, Award Course Completions. Retrieved from: www.deewr.gov.au/HigherEducation/Publications/HEStatistics/Publications/ Pages/Students.aspx.

Diamond, J. (1992). The Arrow of Disease: Emerging Humanity. Discover Magazine. Retrieved from: https://laulima.hawaii.edu/access/content/user/millerg/ANTH_151/ Anth151Unit2/ArrowofDisease.html.

Diamond, J.M. (1998). Guns, Germs and Steel: A Short History of Everybody for the Last 13,000 Years. London: Vintage.

DiAngelo, R.J. (2006). White Fragility in Racial Dialogues. In: Armstrong, D.E., \& McMahon, B.J. (Eds) Inclusion in Urban Educational Environments: Addressing Issues of Diversity, Equity, and Social Justice. Greenwich, CT: Information Age Publishing pp. 213-240.

DiAngelo, R. (2011). White fragility. The International Journal of Critical Pedagogy, 3(3), 54-70.

Dillon, A. (2017). Victim Brigade. Australians at the Crossroads: Talking up Aboriginal Wellbeing. Retrieved from: www.anthonydillon.com.au/single-post/2017/06/18/ Victim-Brigade.

Dobzhansky, T.G. (1962). Mankind Evolving: The Evolution of the Human Species (No. QH368 D6). New Havan, CT: Yale University Press.

Dodson, M. (1994). The End in the Beginning: Re(de)finding Aboriginality. The Wentworth Lecture, The Australian Institute of Aboriginal and Torres Strait Islander Studies. Retrieved from: www.aiatsis.gov.au/events/wentworth/docs/m0008523_a. pdf.

Draper, N. (2017). University College London, Imperial Legacies: Legacies of British Slave Ownership. Retrieved from: www.ucl.ac.uk/lbs/imperial/. 
Dublin University Magazine. (1847). The Famine in the Land. What has been Done, and What is to be Done. April. Retrieved from: http://xroads.virginia.edu/ hyper/sa dlier/irish/Land.htm.

Duke, D. (2017). Charlottesville: Why was Donald Trump's response to the white supremacy rally so controversial? ABC News. Retrieved from: www.abc.net.au/news/ 2017-08-13/donald-trump-charlottesville-white-supremacist-response/8801816.

Durkheim, E. (1912). The Elementary Forms of the Religious Life. n.a.

Dyer, R. (2002). The Matter of Images: Essays on Representation. London: Routledge.

Edmonds, P. (2010). Urbanizing Frontiers: Indigenous Peoples and Settlers in 19th-Century Pacific Rim Cities. Vancouver: UBC Press.

Elias, N. (2001). The Society of Individuals. New York: Continuum.

Ellis, C. (2009). Revision: Auto-ethnographic Reflections on Life and Work. Walnut Creek, CA: Left Coast Press.

Ethnic. (2016). In Macmillan Open Dictionary. Retrieved from: www.macmillandic tionary.com/dictionary/british/ethnic_1\#ethnic_1_1.

Evans, R. (1984). 'Kings' in brass crescents: defining Aboriginal labour patterns in colonial Queensland. In: Saunders, K. (Ed.) Indentured Labour in the British Empire, 1834-1920. London/Canberra: Croom Helm, pp. 183-212.

Evans, R. (1988). Interview. St Lucia, QLD.

Evans, R. (1992). 'Wanton outrage': Police and Aborigines at Breakfast Creek 1860. In: Fisher, R. (Ed.) Brisbane: The Aboriginal Presence 1824-1860. Brisbane History Group Papers No. 11. Kelvin Grove, Qld: Brisbane History Group.

Fabian, J. (2014). Time and the Other: How Anthropology Makes its Object. New York: Columbia University Press.

Fawcett, L., \& Campling, J. (2000). Religion, Ethnicity, and Social Change. Basingstoke: Macmillan.

Ferrari, J. (2010). 'Black armband' history dumped. The Australian. Retrieved from: www.theaustralian.com.au/news/nation/black-armband-history-dumped/news-story/ ae55d083aa68e943a59d2357f3d37901.

Fine, M., Weis, L., Power Pruitt, L., \& Burns, A. (2004). Off White: Readings on Power, Privilege, and Resistance (2nd ed.). New York: Routledge.

Fison, L., \& Howitt, W. (1991). Kamilaroi and Kurnai. Canberra: Aboriginal Studies Press.

FitzSimons, P. (2015). Backlash to Sydney Swans star Adam Goodes' role with David Jones there in black and white: It's nothing but racism. The Sydney Morning Herald. Retrieved from: www.smh.com.au/sport/the-fitz-files/backlash-to-sydneyswans-star-adam-goodes-role-with-david-jones-there-in-black-and-white-its-nothingbut-racism-20151021-gkf0oq.html.

Flood, J. (2001). Archaeology of the Dreamtime: The Story of Prehistoric Australia and its People. Sydney: Angus \& Robertson.

Freire, P. (1993 [1970]). Pedagogy of the Oppressed. New York: Continuum.

Freire, P. (1999). Education and community involvement. In: Castells, M., Flecha, R., Freire, P., Giroux, H., Macedo, D., \& Willis, P. (Eds) Critical Education in the New Information Age. New York: Rowman \& Littlefield, pp. 83-91.

Freire, P., \& Macedo, D. (1987). Literacies: Reading the Word and the World. South Hadley, MA: Bergin and Harvey.

Gammage, W. (2011). The Biggest Estate on Earth: How Aborigines made Australia. Crows Nest, NSW: Allen \& Unwin. 


\section{References}

Gapp, K., von Ziegler, L., Tweedie-Cullen, R.Y., \& Mansuy, I.M. (2014). Early life epigenetic programming and transmission of stress-induced traits in mammals. Bioessays, 36(5), 491-502.

Gardner, D., Kleiner, J., Milchan, A., \& Pitt, B. (Producer), McKay, A. (Director) (2015). The Big Short [Motion Picture]. United States: Paramount Pictures.

Garfinkel, H. (1967). Studies in Ethnomethodology. Englewood Cliffs, NJ: Prentice-Hall.

Garner, B. (1987). A Dictionary of Modern English Usage. Oxford: Oxford University Press.

Geismar, M. (1962). Was 'Papa' a Truly Great Writer? The New York Times, 1 July. Retrieved from: www.nytimes.com/books/99/07/04/specials/hemingway-trulygreat. html.

Georgatos, G. (2013). Australia's Aboriginal children - The world's highest suicide rate. The Stringer. Retrieved from: http://thestringer.com.au/australias-aborigina 1-children-the-worlds-highest-suicide-rate-926\#.VoUT0VJzPPk.

Georgatos, G. (2014). It is racism killing our people - suicides born of racism. The Stringer. Retrieved from: http://thestringer.com.au/it-is-racism-killing-our-people-sui cides-born-of-racism-9152\#.VonSH0ulL8E.

Georgatos, G. (2015). The extensiveness of Aboriginal \& Torres Strait Islander suicides -1 in 20. The Stringer. Retrieved from: http://thestringer.com.au/the-extensi veness-of-aboriginal-torres-strait-islander-suicides-1-in-20-9721\#.VheAVEulL8E.

Gibson, P. (2013). Stolen futures: The revival of Indigenous child removal. Overland, 212, Spring, 44-52. Retrieved from http://search.informit.com.au/documentSummary; $\mathrm{dn}=201223857$;res=IELAPA.

Giddens, A. (1991). Modernity and Self-identity: Self and Society in the Late Modern Age. Standford, CA: Stanford University Press.

Giroux, H. (2001). Theory of Resistance in Education: Towards a Pedagogy for the Opposition. Westport, CT: Bergin \& Garvey.

Godkin, J. (1870). The Land-War in Ireland: A History for the Times. London: Macmillan.

Gonzalez, N., Moll, L., \& Amanti, C. (Eds) (2005). Funds of Knowledge: Theorizing Practices in Households, Communities, and Classrooms. Mahwah, NJ: Lawrence Erlbaum.

Graham, C. (2009). We jail black men five times more than apartheid South Africa. Crikey. Retrieved from: www.crikey.com.au/2009/07/02/we-jail-black-men-five-tim es-more-than-apartheid-south-africa/.

Gribble, J.B. (1887). Dark Deeds in a Sunny Land: Or Blacks and Whites in NorthWest Australia. Missionary to the Natives. Perth: Stirling Bros. Retrieved from: http://nla.gov.au/nla.obj-26173077/view?partId=nla.obj-26175963\#mode/1up.

Grieves, V. (2009). Aboriginal Spirituality: Aboriginal Philosophy, the Basis of Aboriginal Social and Emotional Wellbeing. Discussion Paper No. 9. Darwin, NT: Cooperative Research Centre for Aboriginal Health.

Haebich, A. (2016). Neoliberalism, Settler Colonialism and the History of Child Removal in Australia. Australian Law Review, 19(1), 20-31.

Hallam, S.J. (1985). The history of Aboriginal firing. In: Ford, J.R. (Ed.) Fire Ecology and Management in Western Australian Ecosystems. Perth, WA: Western Australian Institute of Technology, pp. 7-20.

Hallegatte, S., Bangalore, M., Fay, M., Kane, T., \& Bonzanigo, L. (2015). Shock Waves: Managing the Impacts of Climate Change on Poverty. Washington, DC: World Bank Publications. 
Hamacher, D. (2014). Stories from the sky: Astronomy in Indigenous knowledge. The Conversation. Retrieved from: http://theconversation.com/stories-from-the-sky-astro nomy-in-indigenous-knowledge-33140.

Hanssens, L. (2011). Suicide Echo Clusters: Are they Socially Determined, and the Result of a Pre-existing Vulnerability in Indigenous Communities in the Northern Territory? Aboriginal and Islander Health Worker Journal, 35(1), 14.

Hart, V. (2003). Teaching Black and Teaching Back. Social Alternatives, 223, 12-16.

Hayes, L. (2002). The tangible link: Historical archaeology and the cultural heritage of the Australian South Sea Islanders. Australasian Historical Archaeology, 20, 77-82.

Henderson, S., Holland, J., McGrellis, S., Shapre, S., Thomson, R. (2012). Inventing Adulthoods: A Biographical Approach to Youth Transitions. London: SAGE.

Hikuroa, D. (2009). Seminar Series: Integrating Indigenous Knowledge with Science. Nga Pae o te 2009 seminar series [online video series]. Retrieved from: www.ma ramatanga.ac.nz/news-events/events/ng $\% \mathrm{C} 4 \% 81$-pae-o-te-m $\% \mathrm{C} 4 \% 81$ ramatanga-200 9-seminar-series-2.

Hodge, B., \& Mishra, V. (1991). Dark Side of the Dream: Australian Literature and the Postcolonial Mind. Crows Nest, NSW: Allen \& Unwin.

Houston, J. (2007). Indigenous Autoethnography: Formulating Our Knowledge Our Way. Australian Journal of Indigenous Education, 36, Supplement, 34-50.

Huggins, J. (2003). Always Was Always Will Be. In: Grossman, M. (Ed.) Blacklines: Contemporary Critical Writing by Indigenous Australians. Carlton, Vic.: Melbourne University Press, pp. 60-65.

Hull, G., \& James, M. (2006). Geographies of hope: A study of urban landscapes, digital media, and children's representations of place. In: O’Neill, P. (Ed.) Blurring Boundaries: Research and Teaching Beyond a Discipline. Cresskill, NJ: Hampton Press, pp. 225-289.

Husbye, N.E., Buchholz, B.A., Coggin, L.S., Wessel-Powell, C., \& Wohlwend, K.E. (2012). Critical lessons and playful literacies: Digital media in PK-2 classrooms. Language Arts, 90(2), 82-93.

Ivanitz, M. (2000). The Demise of ATSIC? Accountability and the Coalition Government. Australian Journal of Public Administration, 59, 3-12.

Jalata, A. (2013). The impacts of English colonial terrorism and genocide on Indigenous/ Black Australians. Sage Open, 3(3), 1-12,

Janke, T. (2011). Rights to Indigenous cultural knowledge. Key Diversity Areas: Indigenous - Thought Leadership. Retrieved from: www.dca.org.au/indigenous/though t-leadership.html.

Johns, G. (2017). It's just more of the same problems and programs. The Australian. Retrieved from: www.theaustralian.com.au/opinion/columnists/gary-johns/its-just-m ore-of-the-same-problems-and-programs/news-story/4f36c531030c55d1b4f62923440 $5 \mathrm{dffc}$.

Kane, T.S. (1988). The New Oxford Guide to Writing. Oxford: Oxford University Press. Kanu, Y. (2006). Curriculum as Cultural Practice. Toronto: University of Toronto Press.

Kennedy, J. (2016). Election 2016: Pauline Hanson's comments could lead to violence, Tim Soutphommasane warns. ABC News. Retrieved from: www.abc.net.au/news/ 2016-07-05/pauline-hansons-comments-could-lead-to-violence:-soutphommosane/75 68608.

Keyes, R. (2015). Ryan Reynolds' Deadpool Will Smash The Fourth Wall. Screenrant. Retrieved from: http://screenrant.com/ryan-reynolds-deadpool-smash-fourth-wa 1l-rob-15825/. 


\section{References}

Kidd, R. (2006). Trustees on Trial: Recovering the Stolen Wages. Canberra, ACT: Aboriginal Studies Press.

Kiernan, B. (2007). Blood and Soil: A World History of Genocide and Extermination in from Sparta to Darfur. New Haven, CT: Yale University Press.

Kilborne, B. (1987). On classifying dreams. In: Tedlock, B. (Ed.) Dreaming: Anthropological and Psychological Interpretations. New York: Cambridge University Press.

Kincheloe, J., \& Steinberg, R. (1997). Changing Multiculturalism. Buckingham: Open University Press.

Kingsley, J., Townsend, M., Henderson-Wilson, C., \& Bolam, B. (2013). Developing an Exploratory Framework Linking Australian Aboriginal Peoples' Connection to Country and Concepts of Wellbeing. International Journal of Environmental Research and Public Health, 10(2), 678-698. doi:10.3390/ijerph10020678.

Klein, N. (2000). No Logo. London: Flamingo.

Knox, R. (1983). Myall Creek Massacre, Discussion with Reg Knox. Logan, QLD.

Knox, R. (2012). Interview with Reg Knox. 10 January. Logan, QLD.

Komolafe, O. (2010). Colloquies: The African Poet, the African Philosopher, and the African Physicist: A Discourse. New York: iUniverse.

Kopytoff, B.K. (1979). Colonial treaty as sacred charter of the Jamaican Maroons. Ethnohistory, 26(1), 45-64.

Langton, M. (1993). Well, I Heard it on the Radio, and Saw it on the Television. North Sydney, NSW: An Essay for the Australian Film Commission.

Langton, M. (2012a). The Quiet Revolution: Indigenous People and the Resources Boom: Lecture 5 - Counting Our Victories: The End of Garvey-ism and the Soft Bigotry of Low Expectations. The Boyer Lectures Retrieved from: http://www.abc. net.au/radionational/programs/boyerlectures/2012-boyer-lectures-245/4427682.

Langton, M. (2012b). Why I continue to be inspired by Pearson. The Australian. Retrieved from: www.theaustralian.com.au/national-affairs/opinion/why-i-continueto-be-inspired-by-pearson/news-story/faf2c70474faca378e07c8b32adea768.

Language Matters. (2011). Ten Canoes: What Does it Teach Us About What it Means to Belong? Retrieved from: https://12en1.wordpress.com/2011/11/02/ten-canoes-wha t-does-it-teach-us-about-what-it-means-to-belong/.

Lankshear, C., \& Knobel, M. (2006). New Literacies: Everyday Practices \& Classroom Learning. New York: Open University Press.

Lawson, T. (2014). The Last Man: A British Genocide in Tasmania. London: Tauris.

LeDoux, J. (1998). The Emotional Brain: The Mysterious Underpinnings of Emotional Life. New York: Simon and Schuster.

Lehman, G. (2004). Authentic and Essential: A Review of Anita M Heiss' DhuuluuYala (To Talk Straight): Publishing Indigenous Literature. Australian Humanities Review, 33, August-October. Retrieved from: www.australianhumanitiesreview.org/a rchive/Issue-August-2004/lehman.html.

Leight, E. (2017). Watch Late-Night Hosts Condemn Charlottesville Attacks, Trump's Lateness: Fallon, Kimmel, Corden, Colbert, Meyers Denounce Racism, Rebuke Trump's Late and Meek Response. Rolling Stone. Retrieved from: www.rollingstone. com/tv/news/fallon-meyers-corden-kimmel-condemn-racism-trumps-reply-w497795.

Leonard, B., \& Mercier, O. (2015). Shaping Indigenous spaces in higher education: An international virtual exchange on Indigenous knowledge (Alaska and Aotearoa). Canadian Journal of Native Education, 37(1), 218-238.

Liddle, C. (2017). Aboriginal history is 'cultural vandalism'? Then I'll proudly wear my Aboriginal flag-starred beret. The Guardian. Retrieved from: www.theguardian. 
com/commentisfree/2017/aug/28/aboriginal-history-is-cultural-vandalism-then-ill-pr oudly-wear-my-aboriginal-flag-starred-beret.

Lionnet, F. (1989). Autobiographical Voices: Race, Gender, Self-portraiture. New York: Cornell University Press.

Lipsitz, G. (2006). The Possessive Investment in Whiteness: How White People Profit from Identity Politics. Philadelphia, PA: Temple University Press.

Loewenstein, A. (2013). Indigenous incarceration rates are a national shame. The Guardian. Retrieved from: www.theguardian.com/commentisfree/2013/nov/01/indi genous-incarceration-rates-are-a-national-shame.

Lomawaima, K.T., \& McCarty, T.L. (2006). 'To Remain an Indian': Lessons in Democracy from a Century of Native American Education. New York: Teachers College Press.

Lopez, G. (2017a). The battle over Confederate statues, explained: Confederate statues have always been about white supremacy. That's why they're coming down. Vox News. Retrieved from: www.vox.com/identities/2017/8/16/16151252/confederate-sta tues-white-supremacists.

Lopez, G. (2017b). The Charlottesville protests are white fragility in action: Here's why white men are acting like the victims in Charlottesville. Vox News. Retrieved from: www.vox.com/identities/2017/8/12/16138558/charlottesville-va-white-fragility.

Lovell, M. (2014). Languages of neoliberal critique: The production of coercive government in the Northern Territory intervention. In: Uhr, J., \& Walter, R. (Eds) Studies in Australian Political Rhetoric. Canberra, ACT: ANU E Press, pp. 221-240.

MacGeoghegan, A., \& Mitchell, J. (1868 [1849]). History of Ireland. Ancient and Modern [1758-62], trans. by P. O'Kelly. Dublin: James Duffy and Co.

Malkin, B. (2009). More Aboriginal children put into care now than during 'Stolen Generations'. The Telegraph. Retrieved from: www.telegraph.co.uk/news/world news/australiaandthepacific/australia/4092776/More-Aboriginal-children-put-into-ca re-now-than-during-Stolen-Generations.html.

Mander, A., Danaher, P.A., Tyler, M.A., \& Midgley, W. (2011). Beyond Binaries in Education Research. Florence, KY: Routledge.

Mangan, M. (2013). The Drama, Theatre and Performance Companion. Basingstoke: Palgrave Macmillan.

Manning, S. (2013). Britain's colonial shame: Slave-owners given huge payouts after abolition. The Independent. Retrieved from: www.independent.co.uk/news/uk/hom e-news/britains-colonial-shame-slave-owners-given-huge-payouts-after-abolition-850 8358.html.

Mannix, L., \& Cowie, T. (2017). Melbourne's Yarra Council drops Australia Day ceremonies despite warning from Turnbull government. The Age: Melbourne. Retrieved from: www.theage.com.au/victoria/yarra-council-drops-australia-day-cerem onies-despite-warning-from-turnbull-government-20170815-gxx18y.html.

Martin, D.F. (2001). Is Welfare Dependency 'Welfare Poison'?: An Assessment of Noel Pearson's Proposals for Aboriginal Welfare Reform. Canberra, ACT: Centre for Aboriginal Economic Policy Research.

Martin, K. (2008). Aboriginal worldview, knowledge and relatedness theory: A framework for pedagogy and praxis and the teaching-learning interface with Aboriginal students. AIATSIS Seminar Series, Canberra, 14 April.

Mascaro, L. (2017). Trump's defense of a neo-Nazi rally crossed a line for many Republicans. What will they do about it? Los Angeles Times. Retrieved from: www. latimes.com/politics/la-na-pol-trump-republicans-20170816-story.html. 


\section{References}

Mathews, R.H. (1895). The Bora, or initiation ceremonies of the Kamilaroi tribe. The Journal of the Anthropological Institute of Great Britain and Ireland, 24, 411-427.

Maxwell, R. (2017). Horror stories: Royal Commission told of rape threats, girls stripsearched with men present and more. Koori Mail.

May, V. (2011). Self, Belonging and Social Change. Sociology, 45(3), 363-378. Retrieved from: http://journals.sagepub.com/doi/pdf/10.1177/0038038511399624.

Maybury-Lewis, D. (1992). Millennium: Tribal Wisdom and the Modern World. New York: Viking Penguin.

McCarthy, T. (2015). Tony Abbott's Indigenous 'lifestyle choices' remark smacks of racism, says UN rapporteur. The Guardian. Retrieved from: www.theguardian. com/australia-news/2015/apr/29/tony-abbotts-indigenous-lifestyle-choices-remark-sma cks-of-racism-says-un-rapporteur.

McCorquodale, J.C. (1997). Aboriginal Identity: Legislative, Judicial and Administrative Definitions. Australian Aboriginal Studies, 2, 24-35.

McDonald, S. (2015). The Australian Slave Trade. Blackfulla Revolution. Retrieved from: www.facebook.com/ourcountryourchoice/videos/505325229607758/.

McGorry, M. (2015). The New Jim Crow. Instagram. December. Retrieved from: www.instagram.com/p/-uVmFzO4Lb/?taken-by=mattmcgorry.

McKinley, E. (1996). Towards an Indigenous Science Curriculum. Research in Science Education, 26, 155-167. Retrieved from: http://dx.doi.org/10.1007/BF02356429.

McLaren, P. (1995). Critical Pedagogy and Predatory Culture: Oppositional Politics in a Post-modern Era. New York: Routledge.

McLeod, D.W. (1982). How the West was Lost: The Native Question in the Development of Western Australia. Port Hedland, WA: D.W. McLeod.

Merrilees, D. (1968). Man the destroyer; late Quaternary changes in the Australian marsupial fauna. $J R$ Soc West Aust, 51, 1-24.

Mignolo, W. (2012). Decolonizing Western epistemology/building decolonial epistemologies. In: Isasi-Díaz, A.M., \& Mendieta, E. (Eds) Decolonizing Epistemologies: Latinalo Theology and Philosophy. New York: Fordham University Press, pp. $19-43$.

Miller, R.J. (1991). Speaking with Forked Tongues: Indian Treaties, Salmon, and the Endangered Species Act. Or. L. Rev., 70, 543.

Milner, R.N. (2007). Race, narrative inquiry, and self-study in curriculum and teacher education. Education and Urban Society, 39(4), 584-609.

Mitchell, T. (1837). Public lecture. London: Royal Geographical Society.

Mitchell, T. (1838). Three Expeditions into the Interior, Vol 1. London: T\&W Boone, pp. $84,95,100$.

Monbiot, G. (2012). On the 12th day of Christmas ... your gift will just be junk. The Guardian. Retrieved from: www.theguardian.com/commentisfree/2012/dec/10/ on-12th-day-christmas-present-junk.

Moreton-Robinson, A. (2003a). I still call Australia home: Indigenous belonging and place in a white postcolonizing society. In: Ahmed, S. (Ed.) Uprootings/Regroundings: Questions of Home and Migration. Oxford: Berg, pp. 23-40.

Moreton-Robinson, A. (2003b). Researching Whiteness: Some Reflections from an Indigenous Woman's Standpoint. Hecate, 29(2), 72-85.

Moreton-Robinson, A. (2004). Whitening Race: Essays in Social and Cultural Criticism. Canberra, ACT: Aboriginal Studies Press.

Morgan, S., \& Reynolds, M. (1987). My Place. Fremantle, WA: Fremantle Arts Centre Press, p. 97ff. 
Morrissey, P. (2003). Moving, Remembering, Singing Our Place. In: Grossman, M. (Ed.) Blacklines: Contemporary Critical Writing by Indigenous Australians. Melbourne, Vic: Melbourne University Press, pp. 189-193.

Moskovitch, G. (2016). The Briggs \& Thelma Plum Saga Just Keeps Getting Uglier. TONE DEAF. Retrieved from: www.tonedeaf.com.au/470279/the-briggs-thelma -plum-saga-just-keeps-getting-uglier.htm.

Muhammad, K. (1994). The Phil Donahue Show. CBS, Chicago. Retrieved from: www. youtube $. \mathrm{com} /$ watch? $\mathrm{v}=\mathrm{Gb} 4 \mathrm{sn} 622 \mathrm{iOs}$.

Mulvaney, D.J., \& White, J.P. (Eds) (1987). Australians to 1788. Sydney: Fairfax, Syme \& Weldon.

Munro, C. (2011). Reflections from Myall Creek. The Tracker. Retrieved from: http://a rchive.fo/4oo08.

Murdoch, W. (1917). The Making of Australia; an Introductory History. Melbourne, Vic: Whitcomb \& Tombs.

Myers, F. (2002). Painting Culture: The Making of an Aboriginal High Art. Durham: Duke University Press.

Nakata, M. (2002). Indigenous Knowledge and the Cultural Interface: Underlying Issues at the Intersection of Knowledge and Information Systems. In: Hudson, A.H., Matthews, J., \& Woods, A. (Eds) Disrupting Preconceptions: Postcolonialism and Education. Flaxton, QLD: Post Pressed, pp. 19-38.

Nakayama, T., \& Krizek, R. (1995). Whiteness: A strategic rhetoric. Quarterly Journal of Speech, 81(3), 291-309.

National Congress. (2017). National Congress of Australia First Peoples. Retrieved from: http://nationalcongress.com.au.

National Council of Education Statistics. (2015). School Composition \& the BlackWhite Achievement Gap. Retrieved from: https://nces.ed.gov/nationsreportcard/sub ject/studies/pdf/school_composition_and_the_bw_achievement_gap_2015.pdf.

Nicholls, C.J. (2014). 'Dreamtime' and 'The Dreaming': Who dreamed up these terms? The Conversation. Retrieved from: http://theconversation.com/dreamtime-and-thedreaming-who-dreamed-up-these-terms-20835.

Noyes, J. (2015). Miranda Tapsell on racism: 'I don't feel like an Australian'. The Sydney Morning Herald. Retrieved from: www.smh.com.au/lifestyle/celebrity/pop -culture/miranda-tapsell-on-racism-i-dont-feel-like-an-australian-20151016-gkbldi.

Obama, B. (2015). In Interview 'We are Not Cured': Obama Discusses Racism in America with Marc Maron. Retrieved from: www.npr.org/sections/thetwo-way/2015/ 06/22/416476377/we-are-not-cured-obama-discusses-racism-in-america-with-marc-m aron.

Office of the Chief Scientist. (2013). Science, Technology, Engineering and Mathematics in the National Interest: A Strategic Approach. Canberra, ACT: Australian Government.

O'Regan, H. (1999). If it's Good Enough for You it's Good Enough for Me: The Hypocrisy of Assimilation. In: Brown, J. \& Sant, P. (Eds) Indigeneity: Construction and Re/Presentation. New York: Nova Science, pp. 193-208.

Originalpeople. (2013). Origins of the song 'Kumbaya': From a Black Spiritual to a 1960's folk classic. Original People. Retrieved from: http://originalpeople.org/ true-origins-song-kumbayafrom-black-spiritual-1960s-folk-classic/.

Orwell, G. (1945). Animal Farm. London: Secker and Warburg.

Paradies, Y.C. (2006). Beyond Black and White: Essentialism, Hybridity and Indigeneity. Journal of Sociology, 42(4), 355-367. 
Parbury, N. (1986). Survival, a History of Aboriginal Life in New South Wales. Sydney: Ministry of Aboriginal Affairs.

Pascoe, B. (2014). Dark Emu: Black Seeds: Agriculture or Accident? Broome, WA: Magabala Books.

Pearlman, J. (2014). Maori king refuses to meet Duke of Cambridge during New Zealand royal tour. The Telegraph. Retrieved from: www.telegraph.co.uk/news/ worldnews/australiaandthepacific/newzealand/10674776/Maori-king-refuses-to-meet -Duke-of-Cambridge-during-New-Zealand-royal-tour.html.

Pearson, N. (2000). The light on the hill. Ben Chifley Memorial Lecture, 12.

Perry, M. (1999). Australia comes to grips with slave history: Discrimination: Novelist's book recalls the traders who plundered South Pacific islands. Los Angeles Times. Retrieved from: http://articles.latimes.com/1991-10-13/news/mn-745_1_ south-sea-islanders.

Pilger, J., (Producer and Director) \& Lowry, A. (Director) (2013). Utopia (Motion Picture). United Kingdom: Dartmouth Films.

Pilkington, D. (2013). Follow the Rabbit-proof Fence. Brisbane, QLD: University of Queensland Press.

Plum, T. (2016). Facebook post. (@thelmaplum) on 30 January at 9:49pm.

Poole, T. (1972). Conversations with North American Indians. In: Osborne, R. (Ed.) Who is the Chairman of This Meeting?: A Collection of Essays. Toronto: Neewin Publishing Company.

Pope, R. (2005). Creativity: Theory, History, Practice. New York: Routledge.

Prendergast, J.P. (1865). The Cromwellian Settlement of Ireland. Ballycastle: Clachan Publishing.

Presland, G. (1985). The Land of the Kulin: Discovering the Lost Landscape and the First People of Port Phillip. Fitzroy, Vic.: McPhee Gribble/Penguin.

Purdie, N., \& Buckley, S. (2010). School Attendance and Retention of Indigenous Australian Students. Issues Paper No.1 produced for the Closing the Gap Clearinghouse. Canberra, ACT: Australian Institute of Family Studies.

Quinn, L. (2016). Serena Williams 'fan' is slammed as 'disgraceful' after being spotted wearing 'blackface' in the crowd during her match at the Australian Open. Daily Mail. Retrieved from: www.dailymail.co.uk/news/article-3423727/Australian-Op en-fan-wears-blackface-Serena-Williams-match.html.

Ranmuthugala, G., \& Stoneham, M. (2015). FactCheck Q\&A: Are Indigenous youth suicide rates in the top of Australia the highest in the world? The Conversation. Retrieved from: https://theconversation.com/factcheck-qanda-are-indigenou s-youth-suicide-rates-in-the-top-of-australia-the-highest-in-the-world-48760.

Reid, N., \& Dunn, P. (2013). Ancient Aboriginal stories preserve history of a rise in sea level. The Conversation. Retrieved from: http://theconversation.com/ancient-a boriginal-stories-preserve-history-of-a-rise-in-sea-level-36010.

Reynolds, H. (1984). The Breaking of the Great Australian Silence: Aborigines in Australian Historiography 1955-1983. London: University of London, Institute of Commonwealth Studies, Australian Studies Centre.

Richardson, G. (2016). Alan Jones isn't racist, he wants Aboriginal kids to be safe. The Australian. Retrieved from: www.theaustralian.com.au/opinion/columnists/gra ham-richardson/alan-jones-isnt-racist-he-wants-aboriginal-kids-to-be-safe/news-stor y/9f1d66361ec70caa0c111f9eb9595c93.

Robertson, B. (2009). E-mail correspondence. 29 February. 
Robertson, J. (2017a). Australia Day 'a date of mourning' and needs change, NT chief minister says. The Guardian. Retrieved from: www.theguardian.com/australia-news/ 2017/aug/27/australia-day-a-date-of-mourning-and-should-be-changed-nt-chief-mini ster-says.

Robertson, J. (2017b). Leading Indigenous lawyer hits back at Marcia Langton over Adani. The Guardian. Retrieved from: www.theguardian.com/environment/2017/jun/ 09/leading-indigenous-lawyer-hits-back-at-marcia-langton-over-adani.

Robinson, L. (2013). Jay Z on his Rags-to-Riches Story, Wooing Beyoncé, and How Blue Ivy is his 'Biggest Fan'. Vanity Fair. Retrieved from: www.vanityfair.com/cul ture/2013/10/jay-z-beyonce-blue-ivy-story.

Robinson, N., \& Burrell, A. (2014). A nation shamed when child sees suicide as the solution. The Australian. Retrieved from: www.theaustralian.com.au/national-affa irs/indigenous/a-nation-shamed-when-child-sees-suicide-as-the-solution/story-fn $9 \mathrm{hm}$ $1 \mathrm{pm}-1227116504890$.

Rolls, E. (2000). The end, or a new beginning? In: Dovers, S. (Ed.) Environmental History and Policy: Still Settling Australia. Melbourne, Vic: Oxford University Press, pp. $22-46$.

Rose, T. (2014). Imagine having your whole history erased: Indigenous rights activists burn Australian flag during G20 protests. 9 news. Retrieved from: www.9news.com. au/national/2014/11/16/14/36/indigenous-rights-activists-burn-australian-flag-duringg20-protests.

Ross, A.C. (1982). Brain hemispheric functions and the Native American. Journal of American Indian Education, 21(3), 2-5.

Roth, L. (2005). Something in the Air: The Story of First Peoples Television Broadcasting in Canada. Montreal \& Kingston: McGill-Queen.

Rothwell, H. (1996). English Historical Documents, 1189-1327. London: Routledge.

Russell, L. (2002). A Little Bird Told Me. St Leonards, NSW: Allen \& Unwin.

Ryan, P. (2016). Faith-based films still struggling with diversity. USA Today. Retrieved from: www.usatoday.com/story/life/movies/2016/03/10/diversity-young-messiah-pa ssion-fox-easter-movies-tv/81511292/.

Sammel, A.J., \& Waters, M. (2014). Interdisciplinary practice: Dialogue as action to resist colonialism in higher education. Creative Education, 5, 1235-1248. Retrieved from: http://dx.doi.org/10.4236/ce.2014.514139.

Sammut, J. (2017). Traditional culture at odds with closing the gap. The Weekend Australian. Retrieved from: www.theaustralian.com.au/opinion/traditional-culture-a t-odds-with-closing-the-gap/news-story/9595bf05024e9366cc6f5d5fdbbc435d.

Sandywell, B. (2004). The myth of everyday life. Cultural Studies, 18(2), 160-180.

Schloss, K. (2017). Personal correspondence. 25 August.

Schoon, I., McCulloch, A., Joshi, H.E., Wiggins, R.D., \& Bynner, J. (2001). Transitions from school to work in a changing social context. Young, 9(1), 4-22.

Scott, K. (2016). Interview. In: Brewster, M. (Ed.) Giving this Country a Memory: Contemporary Aboriginal Voices of Australia. New York: Cambria Press.

Semali, L.M., \& Kincheloe, J. (Eds) (2002). What is Indigenous Knowledge? Voices from the Academy. London: Routledge.

Serafini, F. (2012). Reading the Visual: An Introduction to Teaching Multimodal Literacy. New York: Teachers College Press.

Shakur, A. (2016). Assata: An Autobiography. London: Zed Books

Shine, R., \& Aird, H. (2016). Hobart Mayor Sue Hickey warns against 'guilt-ridden' Aboriginal focus in MONA waterfront plan. $A B C$ News. Retrieved from: www.abc. 
net.au/news/2016-12-12/mona-hobart-aboriginal-reconciliation-plan-mayor-sue-hick ey/8110456.

Shiva, V. (2008). Soil Not Oil: Climate Change, Peak Oil and Food Insecurity. London: Zed Books.

Simmel, G. (1950). The field of sociology. In: Wolff, G. (Ed. and trans.) The Sociology of Georg Simmel. New York: The Free Press, pp. 3-25.

Simmonds, A. (2015). Australia needs to own up to its slave history. The Sydney Morning Herald. Retrieved from: www.smh.com.au/lifestyle/news-and-views/op inion/australia-needs-to-own-up-to-its-slave-history-20150427-1muhg3.html.

Singh, A. (2010). Avatar hit by accusations of racism. The Telegraph. Retrieved from: www.telegraph.co.uk/culture/film/film-news/6968020/Avatar-hit-by-claims-of-racism. html.

Skeggs, B. (2004). Class, Self, Culture. London: Routledge.

Smallwood, G. (2015). Indigenist Critical Realism: Human Rights and First Australians' Wellbeing. New York: Routledge.

Solorzano, D.G., \& Yasso, T.J. (2002). Critical race methodology: Counter storytelling as an analytical framework for education research. Qualitative Inquiry, 8, 23 -44.

Sparkes, A.C. (2002). Autoethnography: Self-indulgence or something more? In: Bochner, A.P., \& Ellis, C. (Eds) Ethnographically Speaking. Walnut Creek, CA: AltaMira, pp. 209-232.

Spearim, P. (2012). Interview with Paul Spearim. 10 January. Logan, QLD.

Spelt, E.J., Biemans, H.J., Tobi, H., Luning, P.A., \& Mulder, M. (2009). Teaching and learning in interdisciplinary higher education: A systematic review. Educational Psychology Review, 21(4), 365.

Squires, C.R. (2002). Rethinking the black public sphere: An alternative vocabulary for multiple public spheres. Communication Theory, 12(4), 446-468.

Stanford, K.L. (2011). Keepin' it real in hip hop politics: A political perspective of Tupac Shakur. Journal of Black Studies, 42(1), 3-22.

Stanley, P. (2008). Why does Gallipoli mean so much? ABC News. Retrieved from: www.abc.net.au/news/2008-04-25/why-does-gallipoli-mean-so-much/2416166.

Stannard, D.E. (1993). American Holocaust: The Conquest of the New World. New York: Oxford University Press.

Stanner, W.E.H. (1969). After the Dreaming: Black and White Australians - An Anthropologist's View. Sydney: Australian Broadcasting Commission.

Statute of Westminster. (1275). The STATUTES of WESTMINSTER; The First.XI. The National Archives. Retrieved from: www.legislation.gov.uk/aep/Edw1/3/5.

Steele, J. (1983). Aboriginal Pathways. Brisbane: University of Queensland Press.

Stockwell, S. (1994). Louis Pathos. Northern Perspective, 17(2), 40-45.

Street, A. (2017). Closing the gap: Australia is meaner, dumber and more racist than 25 years ago. The Sydney Morning Herald. Retrieved from: www.smh.com.au/ comment/view-from-the-street/closing-the-gap-australia-is-meaner-dumber-and-mor e-racist-than-25-years-ago-20170215-gudgf3.html.

Sturt, C. (1847). An Account of the Seacoast and Interior of South Australia: With Observations on Various Subjects Connected with its Interests. Adelaide, SA: The University of Adelaide. Retrieved from: https://ebooks.adelaide.edu.au/s/sturt/cha rles/s93a/index.html.

Suiter, J. (2016). Post-truth Politics. Political Insight, 7(3), 25-27.

Swain, T. (1993). Place for Strangers: Towards a History of Australian Aboriginal Being. New York: Cambridge University Press. 
Tankersley, J. (2017). Quitting the Paris climate agreement is a moral disgrace: President Trump is selling out our kids to give false hope to coal workers. VOX. Retrieved from: www.vox.com/2017/5/31/15719386/trump-paris-climate-agreem ent-moral-failure.

Taub, A. (2016). Behind 2016's Turmoil, a Crisis of White Identity. The New York Times. Retrieved from: www.nytimes.com/2016/11/02/world/americas/brexit-dona ld-trump-whites.html?_r=0.

Taylor, P. (1993). The Texts of Paulo Freire. Buckingham: Open University Press.

Taylor, R. (2001). About Aboriginality: Questions for the Uninitiated. In: Keen, I., \& Yamada, T. (Eds) Identity and Gender in Hunting and Gathering Societies. Osaka: National Museum of Ethnology.

Tedeschi, M. (2014). The Myall Creek massacre re-examined. Inside History Magazine, 4 June. Wollongong: University of Wollongong.

Tharoor, S. (2016). An Era of Darkness: The British Empire in India. New Delhi: Aleph Book Company.

Thomas, I., \& Kirkpatrick, J.B. (1996). The role of coastlines, people and are in the development of heathlands in northeast Tasmania. Journal of Biogeography, 23, $717-728$.

Thompson, J.B. (1996). Tradition and self in a mediated world. In: Heelas, P. (Ed.) Detraditionalization: Critical Reflections on Authority and Identity. Oxford: Blackwell, pp. 89-108.

Thomson, H. (2015). Study of Holocaust survivors finds trauma passed on to children's genes. The Guardian. Retrieved from: www.theguardian.com/science/2015/a ug/21/study-of-holocaust-survivors-finds-trauma-passed-on-to-childrens-genes.

Trigger, B. (1985). The past as power: Anthropology and the North American Indian. In: McBryde, I. (Ed.) Who Owns the Past?: Papers from the Annual Symposium of the Australian Academy of the Humanities. Oxford: Oxford University Press, pp. 11-40.

Tuck, E., \& Yang, K.W. (2012). Decolonization is not a metaphor. Decolonization: Indigeneity, Education and Society, 1(1), 1-40.

Tuhiwai Smith, L. (1999). Decolonizing Methodologies: Research and Indigenous Peoples. London: Zed Books.

Tuhiwai Smith, L. (2005). On Tricky Ground: Researching the Native in the Age of Uncertainty. In: Denzin, N., \& Lincoln, Y. (Eds) The Sage Handbook of Qualitative Research (3rd ed.).Thousand Oaks, CA: Sage Publications, pp. 85-107.

Tyeson, C. (2016). The mates of these two racist jerks are legit donning sympathy blackface. PEDESTRIAN.TV. Retrieved from: www.pedestrian.tv/news/arts-a nd-culture/the-mates-of-those-two-racist-jerks-are-legit-donn/d922ea77-b93d-49c0-9 bcf-2336b3fd7ff2.htm.

UNESCO. (2016). United Nations Declaration on the Rights of Indigenous Peoples. United Nations Educational, Scientific and Cultural Organization. Retrieved from: http://internationalbillofhumanrights.com/Indigenous\%20PEOPLE.html.

United Nations. (2009). State of the World's Indigenous Peoples. Department of Economic and Social Affairs Division for Social Policy and Development Secretariat of the Permanent Forum on Indigenous Issues. New York: United Nations Publications.

Van Deburg, W.L. (1997). Modern Black Nationalism: From Marcus Garvey to Louis Farrakhan (No. 2). New York: NYU Press.

Victor, T., \& Dalzell, T. (2007). The Concise New Partridge Dictionary of Slang and Unconventional English. London: Routledge. 
Von Liebenstein, G. (2000). Information Technologies in Educational Innovation for Development: Interfacing Global and Indigenous Knowledge. Sixth UNESCOACEID International Conference on Education,12-15 December 2000, The Imperial Queen's Park Hotel, Bangkok, Thailand.

Von Tunzelmann, A. (2016). How historically accurate is The Big Short? The Guardian. Retrieved from: www.theguardian.com/film/2016/jan/27/the-big-short-financia lly-accurate-adam-mckay-subprime-money-bale-gosling-pitt.

Waddy, J.A. (1982). Biological Classification from a Groote Eylandt Aborigine's Point of View. Washington, DC: Center for Western Studies.

Wahlquist, C. (2015). Colin Barnett shrugs off protests against WA's remote community policy. The Guardian. Retrieved from: www.theguardian.com/australia-news/ 2015/may/01/colin-barnett-shrugs-off-protests-against-was-remote-community-policy.

Wahlquist, C., \& Davidson, H. (2015). Close the Gap day: Colin Barnett tells protesters to 'put yourselves in my shoes'. The Guardian. Retrieved from: www.thegua rdian.com/australia-news/2015/mar/19/close-the-gap-day-thousands-rally-threat-rem ote-indigenous-communities.

Warren, C. (2014). Was Sydney's smallpox outbreak of 1789 an act of biological warfare against Aboriginal tribes? $A B C$. Retrieved from: www.abc.net.au/radionationa 1/programs/ockhamsrazor/was-sydneys-smallpox-outbreak-an-act-of-biological-warf are $/ 5395050$.

Waters, M. (2011). Contemporary Urban Indigenous 'Dreamings': Connection, Ceremony and Practice. In: Reifarth, G., \& Morrissey, P. (Eds) Aesopic Voices: Reframing Truth through Concealed Ways of Presentation in the 20th and 21st Centuries. United Kingdom: Cambridge Scholars Publishing, pp. 369-404.

Waters, M. (2012a). Father-to-son conversation. Brisbane, QLD.

Waters, M. (2012b). Contemporary Urban Indigenous 'Dreamings': Interaction, Engagement and Creative Practice, PhD thesis. Brisbane, QLD: Griffith University.

Waters, M. (2013). Nurturing the 'beginning' in protecting our traditional practices from the end: Family, kinship and Kamilaroi Aboriginal First Nation knowledge in Australia. Journal of the European Association for Studies on Australia, 4(1), 177-192.

Waters, M. (2014). Maroon conference: Celebrating a history of Indigenous resistance for our independence. The National Indigenous Times, 25 June.

Waters, M. (2015). Whether you're listening or not, Australia is a nation of white privilege. The Sydney Morning Herald. Retrieved from: www.smh.com.au/comment/ whether-youre-listening-or-not-australia-is-a-nation-of-white-privilege-20151121-gl4 le3.html.

Waters, M. (2016a). Gababala banma-li bumala-y gaalanha ngaawa-y guwaa-1: Healing through resistance and finding voice. Journal of Indigenous Wellbeing: Te Mauri - Pimatisiwin, 1(2). Retrieved from: http://journalindigenouswellbeing.com/ journal_articles/gababala-banma-li-bumala-y-gaalanha-ngaawa-y-guwaa-l-healing-t hrough-resistance-and-finding-voice/.

Waters, M. (2016b). White fragility, white fear: The crisis of racial identity in Australia, and beyond. The Guardian. Retrieved from: www.theguardian.com/comm entisfree/2016/nov/23/white-fragility-white-fear-the-crisis-of-racial-identity-in-austral ia-and-beyond.

Waters, M. (2017a). Did Elijah get Justice. The Koori Mail.

Waters, M. (2017b). Utopia? Kathleen Ngale is 85 years old and living in conditions I can only describe as hell. The Guardian. Retrieved from: www.theguardian.com/ 
commentisfree/2017/jan/24/utopia-kathleen-ngale-is-85-years-old-and-living-in-condi tions-i-can-only-describe-as-hell.

Waters, N. (2012c). Social Studies assignment, Nudgee College, grade eight.

Waters, N. (2017c). Father-to-son conversation, after watching the feature film The Big Short.

Watson, M. (2016). Here are All the High-Profile Australians Who've Defended Blackface Lately. JUNKEE. Retrieved from: http://junkee.com/here-are-all-thehigh-profile-australians-who-defended-blackface-today/73840.

Waxman, O.B. (2016). Michelle Obama Reminded Us that Slaves Built the White House. Here's What to Know. Time History. Retrieved from: http://time.com/ 4423691/michelle-obama-dnc-speech-history/.

Wells, R. (2015). 'We're worried you might steal something': Apple ejects six black students, then apologises following claims of racism. The Sydney Morning Herald. Retrieved from: www.smh.com.au/technology/technology-news/were-worried-you-m ight-steal-something-apple-ejects-six-black-students-then-apologises-following-claim s-of-racism-20151111-gkwkd0?occupyapple.

Wilkie, M. (1997). Bringing Them Home: Report of the National Inquiry into the Separation of Aboriginal and Torres Strait Islander Children from their Families. Sydney: Human Rights and Equal Opportunity Commission.

Williams, L. (2011). The worst bushfires in Australia's history. Australian Geographic. Retrieved from: www.australiangeographic.com.au/topics/science-environment/2011/ 11/the-worst-bushfires-in-australias-history.

Williams, R. (1977). Marxism and Literature. Oxford: Oxford University Press.

Wilmore, L. (2015). I'd Rather We Got Casinos: And Other Black Thoughts. New York: Hyperion.

Wimmer, A. (2002). Why we need black armbands. Journal of Australian Studies, 26(75), $13-16$.

Wissler, R. (1997). Artistic Practice and Research: Towards a Community of Judgement', Double Dialogues - The Arts and their Theoretical Paradigms Conference Proceedings. Deakin University, Melbourne: Theatreworks, pp. 88-105.

Wolff, A. (2015). Story of Patty Mills: Spur, Aussie, Bala. Sports Illustrated. Retrieved from: www.si.com/nba/2015/03/25/patty-mills-australia-san-antonio-spurs-bala-gregg-p opovich.

Wood, A., \& Lewthwaite, B. (2008). Māori Science Education in Aotearoa New Zealand He Puteawhakarawe: Aspirations and Realities. Cultural Studies of Science Education, 3, 625-662. Retrieved from: http://dx.doi.org/10.1007/s11422-008-9089-x.

World Bank. (2015). Rapid, Climate-Informed Development Needed to Keep Climate Change from Pushing More than 100 million People into Poverty by 2030. The World Bank. Retrieved from: www.worldbank.org/en/news/feature/2015/11/08/rap id-climate-informed-development-needed-to-keep-climate-change-from-pushing-mor e-than-100-million-people-into-poverty-by-2030.

Worsley, P.M. (1956). Emile Durkheim's theory of knowledge. The Sociological Review, 4(1), 47-62.

Wright, J. (2002). Apartheid, Australian-style. The Australian Universities' Review, 45(1), pp. 36-39. Retrieved from: http://search.informit.com.au/documentSummary;dn= 941044673361771;res=IELAPA.

Yehuda, R. (2015). How Trauma and Resilience Cross Generations. On Being with Krista Tippett. Retrieved from: www.onbeing.org/program/rachel-yehuda-how-tra uma-and-resilience-cross-generations/transcript/7791. 
Yehuda, R., Bierer, L.M., Schmeidler, J., Aferiat, D.H., Breslau, I., \& Dolan, S. (2000). Low cortisol and risk for PTSD in adult offspring of holocaust survivors. American Journal of Psychiatry, 157(8), 1252-1259.

Yehuda, R., Daskalakis, N.P., Bierer, L.M., Bader, H.N., Klengel, T., Holsboer, F., \& Binder, E.B. (2016). Holocaust exposure induced intergenerational effects on FKBP5 methylation. Biological Psychiatry, 80(5), 372-380.

Yehuda, R., Schmeidler, J., Wainberg, M., Binder-Brynes, K., \& Duvdevani, T. (1998). Vulnerability to posttraumatic stress disorder in adult offspring of Holocaust survivors. American Journal of Psychiatry, 155(9), 1163-1171.

Zips, W. (1999). Nanny: Nana of the Maroons? Some Comparative thoughts on Queen Mothers in Akan and Jamaican Maroon Societies. In: Van Rouveroy van Nieuwaal, E., \& Van Dijk, R. (Eds) African Chieftaincy in a New Socio-Political Landscape. Leiden: African Study Centre, pp. 191-227. 


\section{Index}

Aboriginal and Torres Strait Islander

Commission 50

activism 49, 50, 72

agency: collective 17, 126, 143; personal vii, $14,16,19,32,36,40,85,119,121$, $123,127,137,145,147$

agriculture $77-8,87,109$

ancestral beings $27,85,89,92,139-40$, 142,161

anthropology 1, 10, 26, 53, 71

Aotearoa 4, 53, 62, 77, 98, 100, 135, 140; see also New Zealand

Apple 59, 61

assimilation ix, 19-21, 23, 35-6, 68, 114

austerity ix, 117, 121-2, 143, 156

Australia Day 44, 49, 58, 69, 119, 136, 138, 163-5; see also Invasion Day,

Survival Day

The Australian 52, 64, 66n1, 97

Australian Referendum of 196750

Australian War Memorial 102, 107-8

authenticity ix, 11, 17, 41-42, 81, 124, 149

autoethnography 17,92

Avatar 143

Baldwin, James 101, 125, 144

Barnett, Colin 131

belonging vi, xiii, 7, 35, 37, 40, 60, 98, $112,138-9,144,151$

Beyondblue 60-2

The Big Short 117-18

biological warfare 86-7, 93, 100, 108

black armband history $73,75-6,83 \mathrm{n} 1$

Black History Month 114

Black Lives Matter 101, 115, 121, 129-32

blackbirding 109

blackface $62-5,143$ blackness x, 17, 74, 78, 81-2, 84, 124-5, $127,129,143-4,146,150-1,155$, 160

bloodlines 139, 153, 161

Boer War 102

Bolt, Andrew 3, 48-9, 136

Boxer Rebellion 102

Brexit 3, 39

Brown, Michael 130-1

Bunya 105, 144

burial 161,163

Cambage, Liz 64

Camel Camp 30

Cameron, David 113

capitalism $50-1,143$

civil rights 49,75

Charlottesville 43-7, 49, 80, 119, 121, 137

child abuse 18,68

climate change $77,154,156-7$

Columbus, Christopher 77, 88, 101-2, 119

Columbus Day 119, 163

colonial gaze $5,7,21$

concentration camps 93-4, 102

Coniston Massacre 107-9

consciousness 7, 27, 42, 81, 85, 92, 101, 106, 110, 135, 137, 139-44, 149, 159, 165; Aboriginal 6, 13-14, 17, 24, 26, 32; Australian 62, 111, 112; collective 20, 42, 100, 103, 106, 128; national 65, 98; Western 119

The Conversation xii, 62

Cook, James 77, 101-2

critical race theory $2,7,15 \mathrm{n} 3,23,33,36$, $124-5,156$

Cromwell, Oliver 95-7, 101, 102

cultural appropriation 125, 142, 158-9 


\section{Index}

cultural capital viii, 32, 40, 43, 82, 85, 124,139

cultural maintenance $17,19,37,69,74$, $114,121,134,145,159,163$

Dakota Access Pipeline 131-2, 154-5

dance $12,13,15 \mathrm{n}, 18,38,55,57,75,85$, $103,143,147,155,158-9,161,163$

Darebin council 119, 136

Dark Emu 69

David Jones 59

Deadpool 34

deaths in police custody $65,116,126$, 163

decolonisation $71,84,116,120-2,144$

diaspora 130

disadvantage ix, 14, 122, 134-135

discrimination $3,23-24,48,60-61,67 n$, 116,127

disease 66n, 77-8, 84-91, 93, 96-9, 101, 104, 108-9, 119, 137, 139

dispossession 14, 20, 60, 66n, 83n, 112, 119, 127, 129

Doughty, Elijah 46

Dreaming vii, 7-8, 18, 20, 25-7, 33, 77, $89,92,105,124,139,140,147,154$, 161

Du Bois, W.E.B. 80, 82, 101, 144

Duke, David 45

empathy $13,124-5,126$

employment 19-21, 36, 44, 51, 61, 104, 113

entrepreneurship 50-52, 91, 144

equality ix, 15n, 19-20, 22, 24, 132

equity ix, 6, 14, 19-20, 22, 24, 132

ethnocentrism 71-2

ethnography 9, 10, 17, 92

faith xiii, 3, 25, 36, 66n, 80, 92, 98, 141, $144,147,163$

Fallon, Jimmy 46-47, 49

financial crisis of 2007-08 117

fire burning 69-71, 75-6

first contact 4-5, 90

First World War 87, 107

FitzSimons, Peter 59, 136

fourth wall 33-5, 40, 42-3, 53, 117, 129

Fraser, Malcolm 64

Freedom Rides 50

Gallipoli 107-8

Gammage, Bill 70, 76
Garner, Eric 130-1

Garvey, Marcus 52-3, 67n8, 72, 84, 101, $114,144,149$

genetic memory $20,33,89,100,103,105$, 124

genocide $43-5,53,66,74,76,83 \mathrm{n}, 93-6$, 98, 99-100, 102, 104, 108, 112-14, 116, 119-20, 137-8, 154, 160, 162, 164

Gillen, Francis 26

Globalisation 58, 117

Goodes, Adam 59

grant of title 4

Hanson, Pauline 2-3

Hawke, Bob 2

Hawkes Bay 98, 135

Heyer, Heather 43, 46-7

Hickey, Sue 102-3

Holocaust see Shoah

Howard, John 2, 50-1

Human Rights Commission 48

Hurricane Irma 155, 157

hybrid space 22,33

identity: collective 19, 121; cultural 16, $122,134,163$; individual $17,37,122$, 145

incarceration xiii, 31, 113, 123

indentured labour xiii, 75, 94-6, 100, $109-10,146$

India $77,94-5,100,154$

Indigeneity $\mathrm{x}, 16-19,22,28,32,41-2$, 55,74

Individualism $8,35,50$

initiation $17-18,27,38,42-3,79,85$, $105,110,140-1,145,163$

intellectual property viii, 1, 5, 12, 21, 24, $26,114,125-6$

Invasion Day 138, 163; see also Australia Day, Survival Day

Ireland 95-8, 103, 108, 146

Jamaica 52, 54-9, 62, 98, 113, 135, 155

Jesus Christ 79-82, 84, 141

Jim Crow era $\mathrm{x}, 23,65$

Jones, Alan 64

Jordan, Michael 145

Kalgoorlie 46, 49, 80, 113

King, Rodney 131

Kumbaya 65

Kunek, Alice 64 
land management 57, 70-1, 75-6, 88, 103, 108, 153

Langton, Marcia 34, 52-3, 72, 122, 154

lived experience $\mathrm{x}, 2,6,11,18,125,148$

Lucy 142-3

Lumsden, Frank 54-6

Mabo decision 112

MacSween, Prue 136-7

Mandela, Nelson 84

Māori 4, 53, 102

Marley, Bob 114, 144, 149

Maroons 54-9, 98, 127, 135, 155

Martin, Trayvon 130-2

Marvel 33-6

Materialism vi, 8, 144

memory 4, 25, 68, 72, 101, 106-7; see also genetic memory

mental illness 60, 62, 65; anxiety 22, 39, $62,65,104$; depression 22, 60, 64-5, 104; PTSD 104

Mills, Patty 60

mining vi, 30, 35, 46, 51-2, 57-8, 67n5, $68,113,116,121,135,154$

missions 48-9, 51, 66n2, 75, 113, 144, 161

Mitchell, Thomas 70-1

Myall Creek Massacre 105-7, 110, 165

Nazism 45, 46, 49, 99-100, 137-8; neo-Nazism 43, 45

neo-colonialism viii, $36,57,97,121-2$, $125,127,131$

neoliberalism viii, $\mathrm{x}, 7,20,58,116,122$, $143,156,158$

New Zealand vi, 13, 53, 60, 102, 107, 112, 131, 137, 148; see also Aotearoa

Ngale, Kathleen 30

Ngāti Kahungunu 98, 135

Obama, Barack 23-4, 112, 146, 156

Obama, Michelle 146

oral history $12,73,95,103,107$

Pākehā 4, 13, 77

Paradies, Yin 41-2, 74-5

partnership of learning 24, 28

Pascoe, Bruce 69-70, 76

pearling industry 111

Pearson, Noel 52, 122

pedagogy: Aboriginal 10-11, 18, 20, 28, 68-9, 150, 154

Pentecost Island 110
Plum, Thelma 63-4

post-colonialism xii, 51, 103, 122, 127

post-truth 117-19, 121, 136

Potato Famine 96

power: structures $21,23,130$; hierarchy

12; balance 19

protest xiii, 33, 43, 49, 120, 129-31, 138, 155

public housing 18, 20, 34, 92

Racial Discrimination Act 48

racism: institutionalised xii, $23,39,51$, 59, 126; reverse $63,124,126-7$

Rainbow Serpent 159-60

Reagan, Ronald 51

reflexivity $37-40$

reserves 49, 51, 75, 144; see also

missions

resilience 23, 112

Reynolds, Henry 73, 76

Rhodes, Cecil 77, 101-2

rite of passage 19, 129, 145, 159

rock art 12

Rottenest Island 94

Shoah 57, 98-100, 104, 162

Shakur, Tupac 82-4, 127

slavery $18,23,44,54-5,57,62,65,93-7$, 99-101, 104, 109-14, 117, 119-20, 125-7, 136, 138, 146-7, 164-5

smallpox 86-8, 90, 100, 108; see also biological warfare, disease

social capital 32-3, 40, 43, 81-2, 85, 139 , 143,145

social mobility $32,36,39-40,42,85,121$, 123,137

solidarity xi, 10, 19, 120, 122, 127, 129, 132

Sorry Day 73

SOSBlakAustralia 129, 131-2, 155

South Sea Islanders 109-10

sovereignty $4,52-6$

space-time $14,142,151$

Stanner, W.E.H. 26, 72-3

Starvation 90-1, 95-6, 101, 108, 138

Stolen Generation xi, 7, 62, 92, 94, 99, $112-13,116,148,157,160,164$

Sturt, Charles 71

suicide xii, 22-3, 31, 62, 65, 113, 116

substance abuse 22, 92, 101, 104, 112, $114,124,134$

Survival Day 69; see also Australia Day, Invasion Day 


\section{Index}

Tasmania 56, 70, 93-4, 99, 102, 108

Tapsell, Miranda 58-9, 103

Ten Canoes 88-9

Tent Embassy 50

terra nullius 111-12, 114

Thatcher, Margaret 51

third space ix, 2, 5-6, 17, 24, 32-3, 40, $130,149-50$

Till, Emmett 131

Turnbull, Malcolm 44-5, 132, 136

trauma: intergenerational 103; trans-generational 104, 125

treaty $4,49,54-5,98,134-5$

Trump, Donald 3, 39, 45-6, 48, 80, 146, 154-5

un-cultural space 19-21, 37

ultra-conservativism $2-3,48-9,51,73$, 97,121

The Unknown Soldier 108

Utopia 94

violence: domestic vii, $68,112,134$; lateral 19, 48; physical 48, 63 voice: Aboriginal x, 1, 2, 5, 53, 72, $122-3,135,150$

welfare system $3,51-2,68,122,134,136$, 156

wellbeing vi, viii, xii, 8, 32, 61, 85, 100

Welcome to Country $1,15 \mathrm{n} 1,158$

White Australia policy 111, 160

white culture $23,40,84,97,122,147$

white fragility $39,43,45,62,81,98,101$, 131, 155-6

white saviour 143

white supremacy 23, 43-6, 69, 74, 98, $115,116,119,121,138,143$

white privilege vi-x, $4,23,32,59,66$, 76-7, 79, 110, 121, 123-4, 126-7, 136

Windschuttle, Keith 94

xenophobia 3

Yabun 69

Yarra council 44, 90, 119, 136

Zion Hill settlement xi 